\title{
RAFT RIVER GEOSCIENCE CASE STUDY
}

\author{
Max R. Dolenc \\ Laurence C. Hull \\ Steve A. Mizell \\ Brent F. Russell \\ Piotr A. Skiba \\ Jon A. Strawn \\ Julie A. Tullis \\ Reeta Garber \\ Technical Editor
}

Published November 1981

EG\&G Idaho, Inc.

\section{Idaho Falls, Idaho 83415}

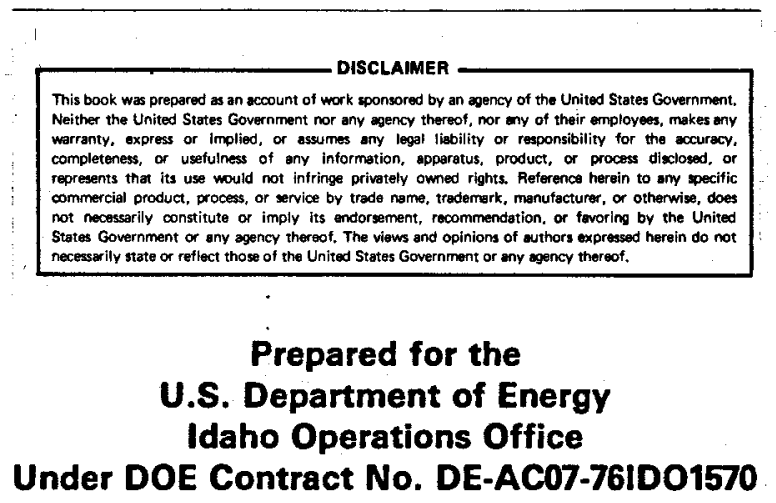




\section{DISCLAIMER}

This report was prepared as an account of work sponsored by an agency of the United States Government. Neither the United States Government nor any agency Thereof, nor any of their employees, makes any warranty, express or implied, or assumes any legal liability or responsibility for the accuracy, completeness, or usefulness of any information, apparatus, product, or process disclosed, or represents that its use would not infringe privately owned rights. Reference herein to any specific commercial product, process, or service by trade name, trademark, manufacturer, or otherwise does not necessarily constitute or imply its endorsement, recommendation, or favoring by the United States Government or any agency thereof. The views and opinions of authors expressed herein do not necessarily state or reflect those of the United States Government or any agency thereof. 


\section{DISCLAIMER}

Portions of this document may be illegible in electronic image products. Images are produced from the best available original document. 


\begin{abstract}
The Raft River Geothermal Site has been evaluated over the past eight years by the United States Geological Survey and the Idaho National Engineering Laboratory as a moderate-temperature geothermal resource. The geoscience data gathered in the drilling and testing of seven geothermal wells suggest that the Raft River thermal reservoir is: (a) produced from fractures found at the contact metamorphic zone, apparently the base of detached normal faulting from the Bridge and Horse Well Fault zones of the Jim Sage Mountains; (b) anisotropic, with the major axis of hydraulic conductivity coincident to the Bridge Fault Zone; (c) hydraulically connected to the shallow thermal fluid of the Crook and BLM wells based upon both geochemistry and pressure response; (d) controlled by a mixture of diluted meteoric water recharging from the northwest and a saline sodium chloride water entering from the southwest. Although the hydrogeologic environment of the Raft River geothermal area is very complex and unique, it is typical of many Basin and Range systems.
\end{abstract}




\section{ACKNOWLEDGMENTS}

This report contains information collected over seven years. Although many people contributed to making this effort successful, it is impossible to acknowledge everyone. We do wish to thank the Department of Energy, Idaho Operations Office; the Department of Energy, Headquarters; the United States Geological Survey; the Idaho Bureau of Mines and Geology; Boise State University; Lawrence Berkeley Laboratory; Reynolds Electrical Engineering Company; and the University of Idaho. We also thank EG\&G management and field personnel, both present and past employees, who assisted in gathering, compiling, and analyzing the data presented in this report. 


\section{CONTENTS}

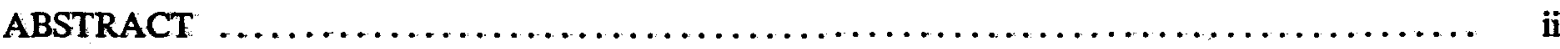

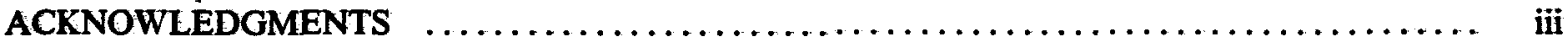

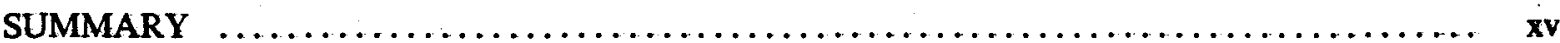

1. INTRODUCTION AND BACKGROUND $\ldots \ldots \ldots \ldots \ldots \ldots \ldots \ldots \ldots \ldots \ldots \ldots \ldots \ldots \ldots \ldots \ldots$

2. GEOLOGY OF THE RAFT RIVER GEOTHERMAL SITE $\ldots \ldots \ldots \ldots \ldots \ldots \ldots \ldots \ldots$

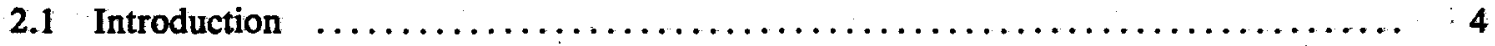

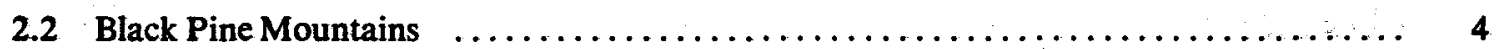

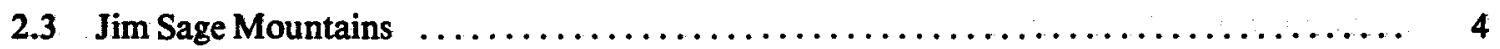

2.4 Raft River Range $\ldots \ldots \ldots \ldots \ldots \ldots \ldots \ldots \ldots \ldots \ldots \ldots \ldots \ldots \ldots \ldots \ldots \ldots \ldots \ldots \ldots \ldots, \quad 4$

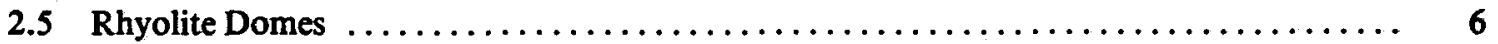

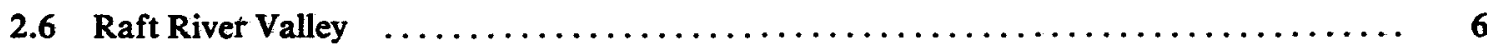

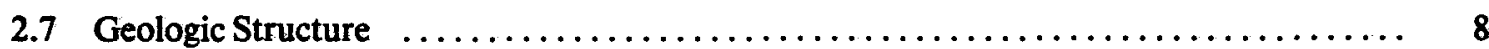

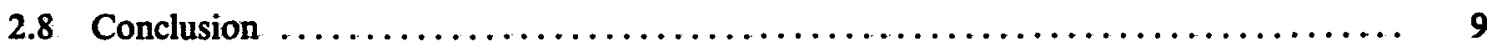

3. GEOPHYSICS OF WELLS IN THE RAFT RIVER GEOTHERMAL SITE $\ldots \ldots \ldots \ldots \ldots$

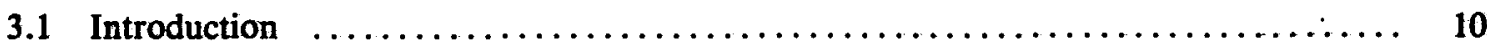

3.2 The Logging Program and Fracture Identification $\ldots \ldots \ldots \ldots \ldots \ldots \ldots \ldots$

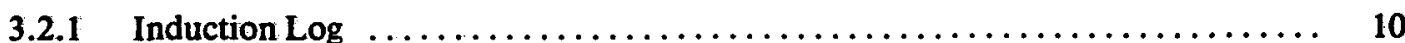

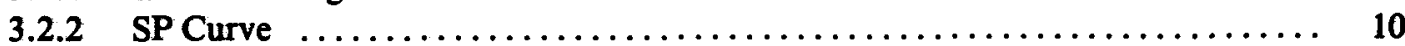

3.2.3 Acoustic, Density, and Neutron Logs $\ldots \ldots \ldots \ldots \ldots \ldots \ldots \ldots \ldots \ldots \ldots \ldots \ldots$

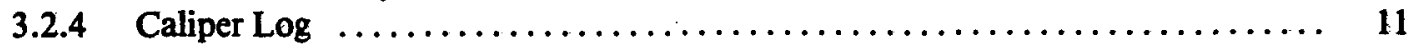

3.2.5 Other Borehole Tools for Fracture Detection $\ldots \ldots \ldots \ldots \ldots \ldots \ldots \ldots \ldots$

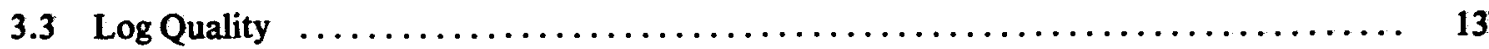

3.3.1 Establishing a Definitive Logging Program $\ldots \ldots \ldots \ldots \ldots \ldots \ldots \ldots \ldots \ldots \ldots$

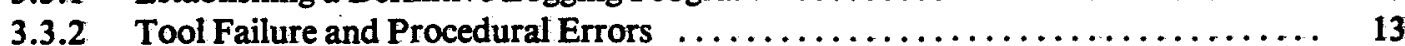

3.4 Classification of the Raft River Geothermal Reservoir from the Viewpoint of $\log$ Analysis $\ldots \ldots \ldots \ldots \ldots \ldots \ldots \ldots \ldots \ldots \ldots \ldots \ldots \ldots \ldots \ldots \ldots \ldots, 22$

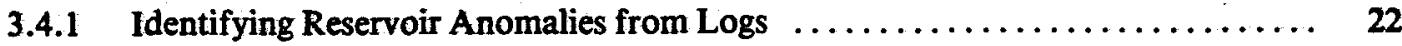

3.4.2 Crossplot Interpretation $\ldots \ldots \ldots \ldots \ldots \ldots \ldots \ldots \ldots \ldots \ldots \ldots \ldots \ldots \ldots \ldots \ldots \ldots \ldots \ldots \ldots, \quad 38$

3.4.3 Lithologic Indications from Logs $\ldots \ldots \ldots \ldots \ldots \ldots \ldots \ldots \ldots \ldots \ldots \ldots, 38$

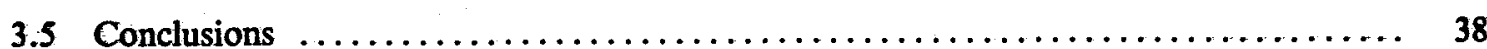


4. HYDROLOGY OF THE RAFT RIVER GEOTHERMAL SITE

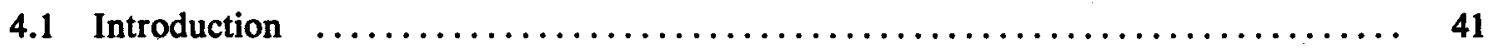

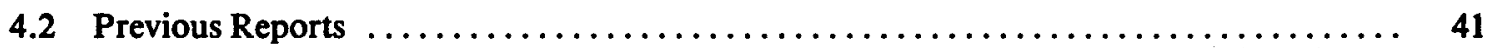

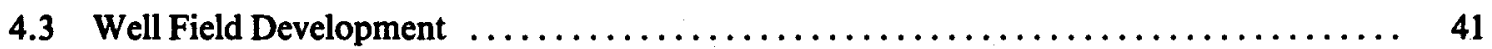

4.4 Methods of Well Testing $\ldots \ldots \ldots \ldots \ldots \ldots \ldots \ldots \ldots \ldots \ldots \ldots \ldots \ldots \ldots \ldots \ldots \ldots \ldots \ldots \ldots, \quad 42$

4.4.1 Well Tests During Drilling $\ldots \ldots \ldots \ldots \ldots \ldots \ldots \ldots \ldots \ldots \ldots \ldots \ldots \ldots, \quad 42$

4.4.2 Artesian Flow Well Tests $\ldots \ldots \ldots \ldots \ldots \ldots \ldots \ldots \ldots \ldots \ldots \ldots \ldots \ldots \ldots, \quad 43$

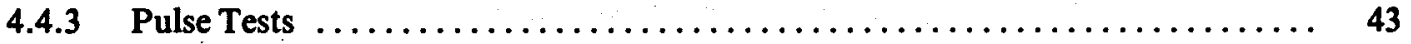

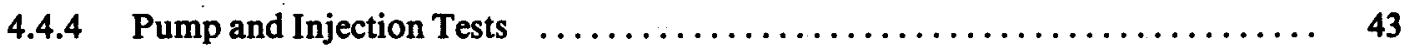

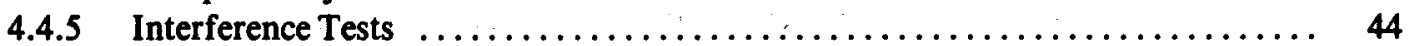

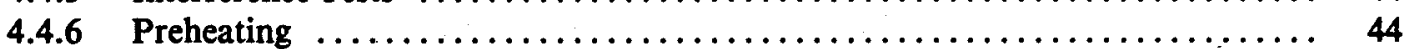

4.4.7 Evaluation of Fractured Flow $\ldots \ldots \ldots \ldots \ldots \ldots \ldots \ldots \ldots \ldots \ldots \ldots \ldots \ldots \ldots \ldots \ldots \ldots \ldots \ldots, \quad 44$

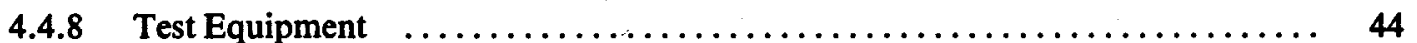

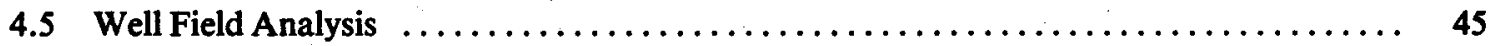

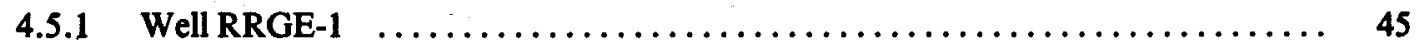

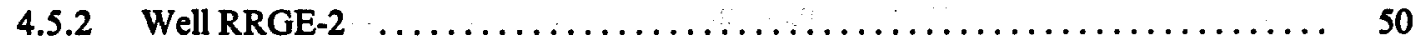

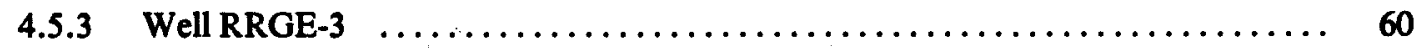

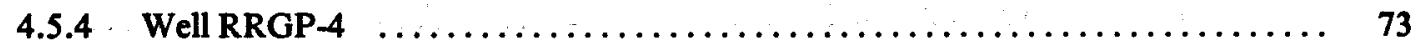

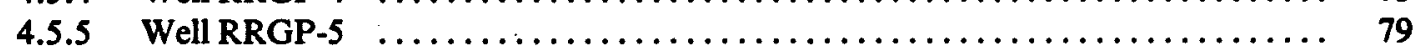

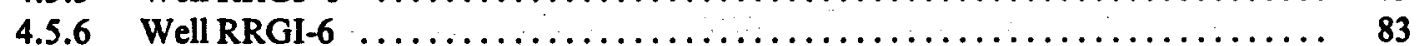

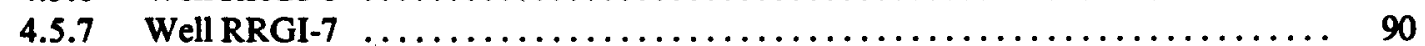

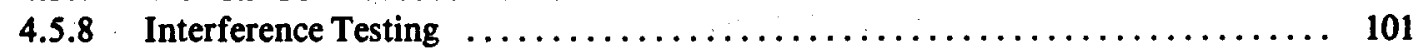

4.5.9 Monitor Well Effects $\ldots \ldots \ldots \ldots \ldots \ldots \ldots \ldots \ldots \ldots \ldots \ldots \ldots \ldots \ldots \ldots$

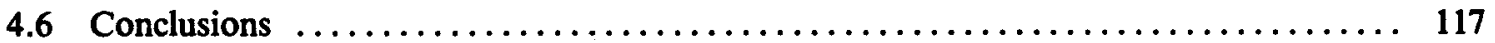

5. GEOCHEMISTRY OF THE RAFT RIVER GEOTHERMAL SITE $\ldots \ldots \ldots \ldots \ldots \ldots \ldots \ldots$

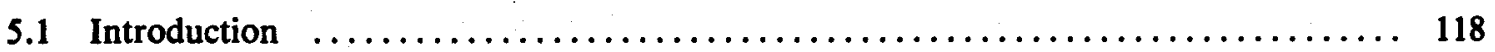

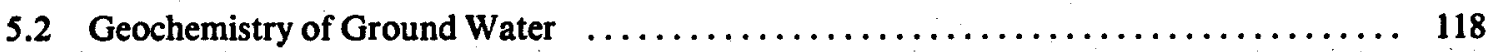

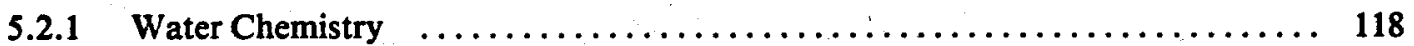

5.2.2 Distribution of Physical Parameters and Chemical Species $\ldots \ldots \ldots \ldots \ldots \ldots .120$

5.2.3 Conceptual Model ....................................... 128

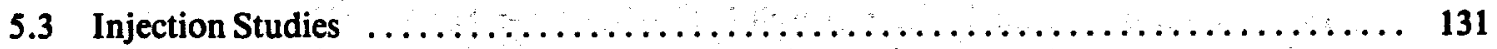

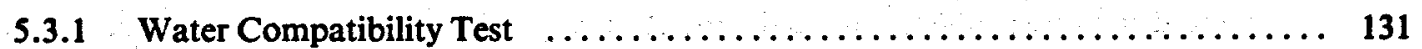

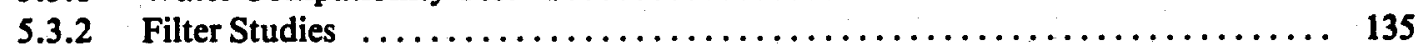

5.4 Conclusions $\ldots \ldots \ldots \ldots \ldots \ldots \ldots \ldots \ldots \ldots \ldots \ldots \ldots \ldots \ldots \ldots \ldots \ldots \ldots \ldots \ldots, 138$

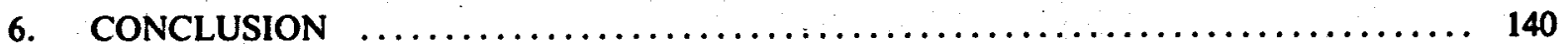

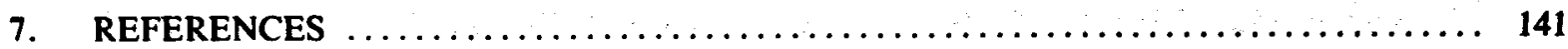




\section{FIGURES}

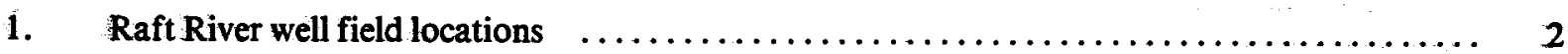

2. Raft River Valley and major structural features adjoining the valley $\ldots \ldots \ldots \ldots \ldots \ldots \ldots$

3a. An early interpretation of the Bridge Fault Zone $\ldots \ldots \ldots \ldots \ldots \ldots \ldots \ldots \ldots \ldots$

3b. A later interpretation of the Bridge Fault Zone illustrating no

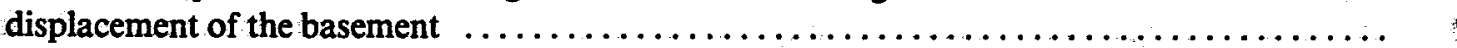

4. M-N crossplot with unique rock materials from Raft River $\ldots \ldots \ldots \ldots \ldots \ldots \ldots \ldots \ldots$

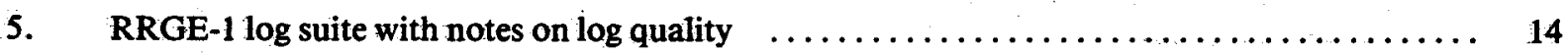

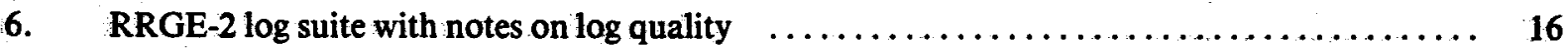

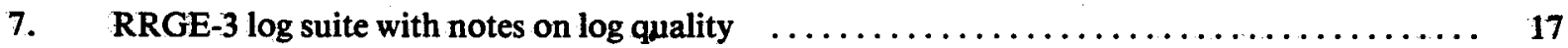

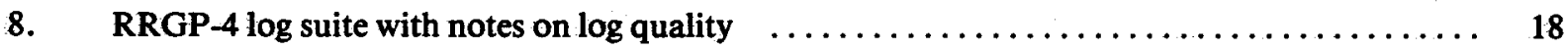

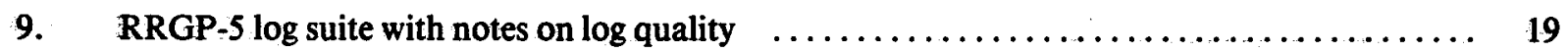

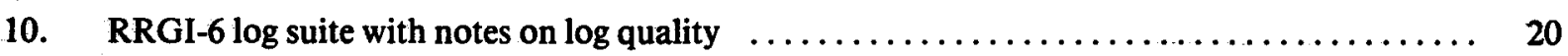

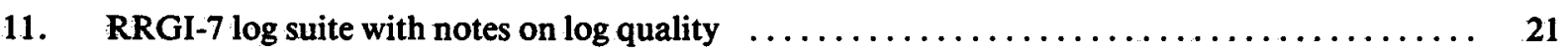

12. Anomalous zones from data on RRGE-1 $\ldots \ldots \ldots \ldots \ldots \ldots \ldots \ldots \ldots \ldots \ldots \ldots \ldots \ldots \ldots \ldots \ldots \ldots$

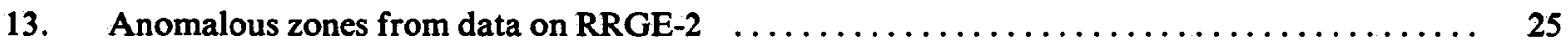

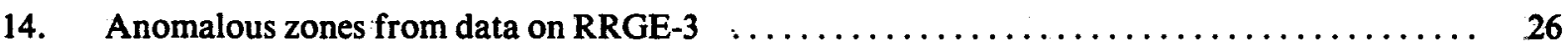

15. Anomalous zones from data on RRGP-5 $\ldots \ldots \ldots \ldots \ldots \ldots \ldots \ldots \ldots \ldots \ldots \ldots \ldots \ldots \ldots \ldots \ldots$

16. Anomalous zones from data on RRGI-6 $\ldots \ldots \ldots \ldots \ldots \ldots \ldots \ldots \ldots \ldots \ldots \ldots \ldots \ldots \ldots \ldots \ldots$

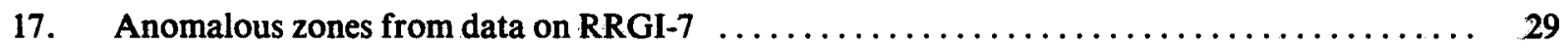

18. Bulk density-porosity plot from Schlumberger modified to show

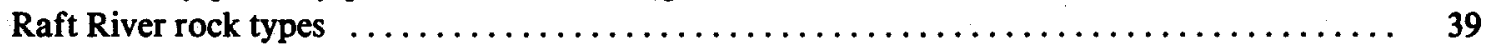

19. Drawdown during production test of well RRGE-1, November 5, 1975 at a discharge rate of $1.7 \mathrm{~L} / \mathrm{s}$ for 30 continuous hours. Data obtained with downhole pressure probe (abstracted from Reference 65.$) \quad \ldots \ldots \ldots \ldots \ldots \ldots \ldots \ldots \ldots \ldots$

20. Recovery from production test of well RRGE-1, November 5, 1975 at a discharge rate of $1.7 \mathrm{~L} / \mathrm{s}$ for 30 continuous hours. Data obtained with downhole pressure probe (abstracted from Reference 65.)

21. Drawdown during production test of well RRGE-1, February 2, 1976 at a discharge rate of $55.5 \mathrm{~L} / \mathrm{s}$ for 99 continuous hours. Initial wellhead pressure was $1200 \mathrm{kPa}$ 
22. Drawdown during production test of well RRGE-1, October 15, 1979 at a discharge rate of $63 \mathrm{~L} / \mathrm{s}$ for 80 hours with one 14 minute pause after 300 minutes. Maximum discharge temperature was $142^{\circ} \mathrm{C}$

23. Recovery from production test of well RRGE-1, October 15, 1979 at a discharge rate of $63 \mathrm{~L} / \mathrm{s}$ for 80 hours with one 14 minute pause after 300 minutes

24. Drawdown during production test of well RRGE-1, August 18, 1980 at an average discharge rate of $61.5 \mathrm{~L} / \mathrm{s}$. During the test there were numerous pump outages

25. Recovery from production test of well RRGE-1, August 18, 1980 at an average discharge rate of $61.5 \mathrm{~L} / \mathrm{s}$

26. Productivity curve of 24-hour data from exploratory well RRGE-1

27. Expected drawdown versus flow rate at exploratory well RRGE-1 (not including interference effects)

28. Drawdown during pulse testing of well RRGE-2, February through March 1977

29. Recovery from pulse testing of well RRGE-2, February 18,1977 at a discharge rate of $12.6 \mathrm{~L} / \mathrm{s}$ for 24 hours. (For recovery tests, time is measured starting from the time of pump shut-in.)

30. Drawdown during production test of well RRGE-2, May 30, 1978 at a discharge rate of $46.7 \mathrm{~L} / \mathrm{s}$ for 200 continuous hours

31. Drawdown during production test of well RRGE-2, January 9, 1979 at a discharge rate of $6.3 \mathrm{~L} / \mathrm{s}$ for 72 continuous hours $\ldots \ldots \ldots \ldots \ldots \ldots \ldots \ldots \ldots . \ldots \ldots$

32. Drawdown during production of well RRGE-2, March 20, 1979 at a discharge rate of $37.8 \mathrm{~L} / \mathrm{s}$ for 504 hours. Data obtained by surface gauge on a continuous bubbler tube. Initial bubbler tube pressure was $3033 \mathrm{kPa}$

33. Recovery from production test of well RRGE-2, March 20, 1979 at a discharge rate of $37.8 \mathrm{~L} / \mathrm{s}$ for 504 hours. Data obtained by surface gauge on a continuous tube

34. Drawdown during production of well RRGE-2, August 11, 1979 at a discharge rate of $28.41 \mathrm{~L} / \mathrm{s}$ for 92 hours. Data obtained by surface gauge on the wellhead annulus

35. Productivity curve of 24-hour data from exploratory well RRGE-2

36. Expected drawdown versus flow rate at exploratory well RRGE-2

(not including interference effects)

37. Drawdown during production test of well RRGE-3, June 8, 1976 at an average discharge rate of $8.6 \mathrm{~L} / \mathrm{s}$ for 193 hours (analyzed by Lawrence Berkeley Laboratory) 
38. Recovery from production test of well RRGE-3, June 8, 1976 at

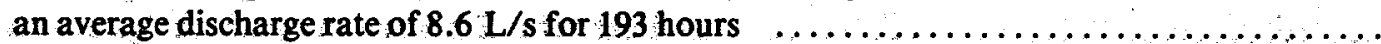

39. Drawdown during production test of well RRGE-3, March 8, 1977 at

an average discharge rate of $22.1 \mathrm{~L} / \mathrm{s}$ for 24 hours

40. Drawdown during production test of well RRGE-3, June 6, 1977

at a discharge rate of $37.9 \mathrm{~L} / \mathrm{s}$ for 24 hours. Static (cold) water level

was $47.9 \mathrm{~m}$ above ground level

41. Drawdown during production test of well RRGE-3, June 29, 1977

at a discharge rate of $49.6 \mathrm{~L} / \mathrm{s}$ for 24 hours. Static (cold) water level

was $78.9 \mathrm{~m}$ above ground level

42. Drawdown during production test of well RRGE-3, July 6, 1977

at a discharge rate of $37.9 \mathrm{~L} / \mathrm{s}$ for 288 hours

43. Calculated recovery from production test of well RRGE-3, July 6, 1977

at a discharge rate of $37.9 \mathrm{~L} / \mathrm{s}$ for 288 hours

44. Drawdown during production test of well RRGE-3, November 17, 1977

at a discharge rate of $37.9 \mathrm{~L} / \mathrm{s}$ for 24 hours

45. Drawdown during production test of well RRGE-3, December 22, 1977

at a discharge rate of $37.9 \mathrm{~L} / \mathrm{s}$ for 575 hours

46. Recovery from production test of well RRGE-3, December 22, 1977

at a discharge rate of $37.9 \mathrm{~L} / \mathrm{s}$ for 575 hours

47. Bubbler pressure versus wellhead pressure for recovery of the production

test of well RRGE-3, December 22, 1977

48. Drawdown during production test of well RRGE-3, January 31,1978

at a discharge rate of $41 \mathrm{~L} / \mathrm{s}$ for 240 hours

49. Drawdown during production test of well RRGE-3, March 19, 1981

at an average discharge rate of $\mathbf{4 4 . 2} \mathrm{L} / \mathrm{s}$ for $\mathbf{2 5 0}$ hours with numerous

pump outages

50. Recovery from production test of well RRGE-3, March 19, 1981

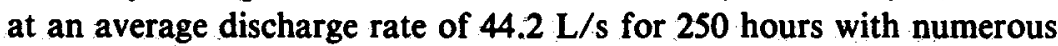

pump outages

51. Productivity curve of 24-hour data from exploratory well RRGE-3

52. Predicted wellhead pressure decline for artesian flowing conditions

at well RRGE-3

53. Expected drawdown versus flow rate at exploratory well RRGE-3

(not including interference effects)

54. Wellhead pressure and temperature during production test of well

RRGI-4, November 2, 1977 at a discharge rate of $6.3 \mathrm{~L} / \mathrm{s}$ for 167 continuous hours 
55. Wellhead pressure and temperature during injection test of well RRGI-4, May 30, 1978 at a discharge rate of $44.1 \mathrm{~L} / \mathrm{s}$ for 221 continuous hours $\ldots \ldots \ldots \ldots \ldots \ldots .77$

56. Productivity curve of 24 -hour data from production well RRGP $-4 \ldots \ldots \ldots \ldots \ldots \ldots \ldots, 78$

57. Expected pressure response versus injection rate at production well RRGP-4 (not including interference effects). This plot is based on data obtained while production well RRGP-4 was at a total depth of $866 \mathrm{~m}$

58. Wellhead pressure and temperature during production test of well RRGP-5, November 1,1978 at a discharge rate of $8.82 \mathrm{~L} / \mathrm{s}$ for 72 continuous hours

59. Bubbler pressure and wellhead temperature during production test of well RRGP-5, May 16, 1979 at a discharge rate of $40.4 \mathrm{~L} / \mathrm{s}$ for 483 continuous hours ......

60. Wellhead pressure during production test of well RRGP-5, June 26, 1979 at a discharge rate of $37.8 \mathrm{~L} / \mathrm{s}$ for 41.7 continuous hours

61. Productivity curve of 24-hour data from production well RRGP-5 $\ldots \ldots \ldots \ldots \ldots \ldots \ldots$

62. Expected pressure response versus discharge rate at production well RRGP-5 (not including interference tests)

63. Pressure buildup during injection test of well RRGI-6, January 10-13, 1979. The test ran for 72 hours at an injection rate of $44.2 \mathrm{~L} / \mathrm{s}$. Data collected at the wellhead

64. Pressure buildup and water temperature during injection test of well RRGI-6, January 10-13, 1979. The test ran for 72 hours at an injection rate

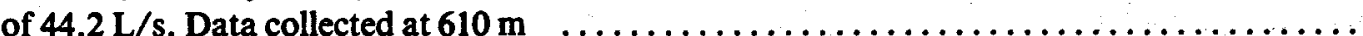

65. Pressure buildup and temperature during injection test of well RRGI-6, March 10-31, 1979. Test duration was 504 hours at an injection rate of $37.8 \mathrm{~L} / \mathrm{s}$

66. Pressure decline during recovery after injection test of well RRGI-6, August 10-31, 1979. Injection rate for $37.8 \mathrm{~L} / \mathrm{s}$ for 504 hours

67. Pressure buildup and temperature during injection test of well RRGI-6,

May 16-June 6, 1979. Test ran for 500 hours at an injection rate of $40.4 \mathrm{~L} / \mathrm{s}$

68. Pressure decline during recovery after injection test of well RRGI-6, May 16-June 6, 1979. Injection was at a rate of $40.4 \mathrm{~L} / \mathrm{s}$ for 500 hours

69. Pressure decline during recovery after injection test of well RRGI-6,

May 14-June 11, 1980. Test ran for 680 hours at an injection rate of $45.7 \mathrm{~L} / \mathrm{s}$

70. Pressure buildup and water temperature during injection test of well RRGI-6, Aügust 19-28, 1980. An injection rate of $56.8 \mathrm{~L} / \mathrm{s}$ was used for 190 hours $\ldots \ldots \ldots$.

71. Pressure decline during recovery after injection test of well RRGI-6, August 19-28, 1980. The test ran for 190 hours at an injection rate of $56.8 \mathrm{~L} / \mathrm{s} \ldots \ldots \ldots \ldots . . .90$

72. Injectivity curve of 24-hour data from injection well RRGI-6 
73. Predicted pressure buildup versus injection rate for injection well RRGI-6

74. Pressure buildup and water temperature during injection test of well

RRGI-7, August 8, 1979 at an injection rate of $39.1 \mathrm{~L} / \mathrm{s}$ for 8 hours

75. Pressure decline during recovery after injection test of well RRGI-7, August 8; 1979. Test ran for 8 hours at an injection rate of $39.1 \mathrm{~L} / \mathrm{s}$

76. Pressure buildup and water temperature during injection test of well RRGI-7, August 11-15, 1979. Test duration was 96 hours at an injection rate of

28.4 L/s. Data collected at the wellhead

77. Pressure decline during recovery after injection test of well RRGI-7, August 11-15, 1979. Test ran for 96 hours at an injection rate of $28.4 \mathrm{~L} / \mathrm{s}$.

Data collected at the wellhead

78. Pressure buildup and temperature during injection test of well RRGI-7,

August 11-15, 1979. Test duration was 96 hours at an injection rate of $28.4 \mathrm{~L} / \mathrm{s}$.

Data collected downhole at a depth of $1130 \mathrm{~m}$

79. Pressure decline during recovery after injection test of well RRGI-7,

August 11-15, 1979. Test ran for 96 hours at an injection rate of $28.4 \mathrm{~L} / \mathrm{s}$.

Data collected downhole at a depth of $1130 \mathrm{~m}$

80. Pressure buildup and temperature during injection test of well RRGI-7,

September 15, 1979. Test duration was 80 hours at an injection rate of $63 \mathrm{~L} / \mathrm{s}$

81. Pressure buildup during injection test of well RRGI-7, August 19-20,

1980. Test duration was 35 hours at an injection rate of $60 \mathrm{~L} / \mathrm{s}$

82. Pressure decline during recovery after injection test of well RRGI-7,

August 19-20, 1980. Test duration was 30 hours at an injection rate of $60 \mathrm{~L} / \mathrm{s}$

83. Pressure decline during recovery after injection test of well RRGI-7,

August 28-September 10, 1980. Test duration was 285 hours at an injection rate

84. Injectivity curve of $24-$ hour data from injection well RRGI-7 $\ldots \ldots \ldots \ldots \ldots \ldots \ldots \ldots . \quad 99$

85. Predicted pressure buildup versus injection rate for injection well RRGI-7 $\ldots \ldots \ldots \ldots \ldots 100$

86. Pressure drawdown observed at well RRGP-4 during production at well RRGE-1 on August 18, 1980. The production rate in RRGE-1 was $56.8 \mathrm{~L} / \mathrm{s}$;

observation of well RRGP-4 continued for 533 hours

87. Pressure drawdown observed at well RRGE-1 during production at

RRGP-5 on May 16, 1979. The production rate was $40.4 \mathrm{~L} / \mathrm{s}$; observation of

well RRGE-1 continued for 417 hours

88. Pressure drawdown observed at well RRGP-4 during production at

RRGP-5 on May 16, 1979. The production rate was $40.4 \mathrm{~L} / \mathrm{s}$; observation of well RRGP-4 continued for 500 hours 
89. Wellhead pressure buildup at well RRGI-7 during injection at

RRGI-6 on May 16, 1979. The injection rate was $40.4 \mathrm{~L} / \mathrm{s}$; observation of

well RRGI-7 continued for 500 hours

90. Wellhead pressure buildup at well RRGI-6 during injection at well RRGI-7

on August 11, 1979. The injection rate was $28.4 \mathrm{~L} / \mathrm{s}$; observation of

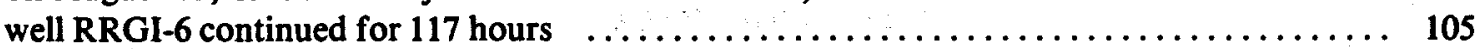

91. Monitor Well-1 (MW-1) long-term hydrograph $\ldots \ldots \ldots \ldots \ldots \ldots \ldots \ldots \ldots \ldots \ldots$

92. Monitor Well-2 (MW-2) long-term hydrograph $\ldots \ldots \ldots \ldots \ldots \ldots \ldots \ldots \ldots \ldots \ldots \ldots \ldots$

93. Monitor Well-3 (MW-3) long-term hydrograph $\ldots \ldots \ldots \ldots \ldots \ldots \ldots \ldots \ldots \ldots \ldots \ldots, 112$

94. Monitor Well-4 (MW-4) long-term hydrograph $\ldots \ldots \ldots \ldots \ldots \ldots \ldots \ldots \ldots \ldots \ldots$

95. Monitor Well-5 (MW-5) long-term hydrograph $\ldots \ldots \ldots \ldots \ldots \ldots \ldots \ldots \ldots \ldots \ldots \ldots$

96. Monitor Well-6 (MW-6) long-term hydrograph $\ldots \ldots \ldots \ldots \ldots \ldots \ldots \ldots \ldots \ldots \ldots$

97. Monitor Well-7 (MW-7) long-term hydrograph $\ldots \ldots \ldots \ldots \ldots \ldots \ldots \ldots \ldots \ldots \ldots \ldots$

98. Specific conductance of shallow $(<200 \mathrm{~m})$ ground water in the

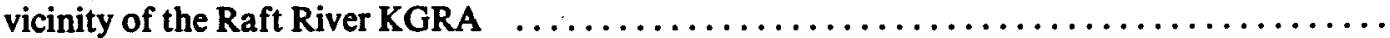

99. Temperature of shallow $(<200 \mathrm{~m})$ ground water in the vicinity of the

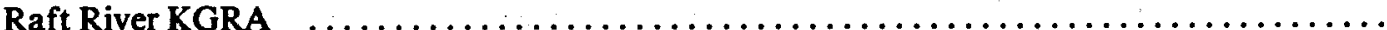

100. Cross section through the Raft River KGRA showing distribution of specific conductance of ground water. (Location of Section A - A is shown in Figure 1.)

101. Cross section through the Raft River KGRA showing distribution of

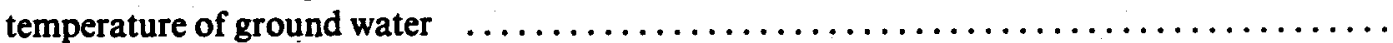

102. Cross section through the Raft River KGRA showing distribution of silica in ground water

103. Cross section through the Raft River KGRA showing distribution of

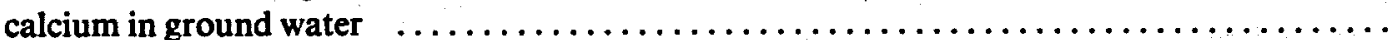

104. Cross section through the Raft River KGRA showing distribution of

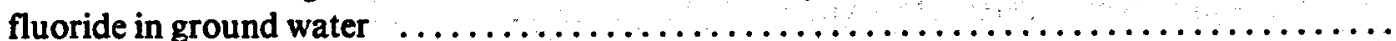

105. Plot of calcium and fluoride concentrations showing relation to fluoride saturation

106. Plot of oxygen and hydrogen isotopic composition of ground waters showing relationship to meteoric water line

107. Comparison of measured and calculated chloride concentrations based on mixing model 
108. Sodium and potassium corner of cation, trilinear diagram showing percentage

of cationic compositions of ground water

109. Chloride and fluoride corner of anion, trilinear diagram showing percentage

of anionic compositions of ground waters

110. Conceptual model of flow in the Raft River KGRA

\section{TABLES}

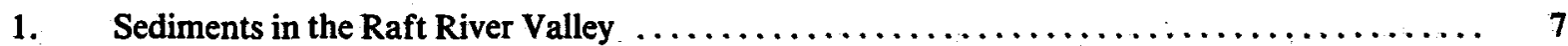

2. Mineral constituents in the Salt Lake Formation $\ldots \ldots \ldots \ldots \ldots \ldots \ldots \ldots \ldots \ldots \ldots \ldots$

3. Limitations and special character of logging tools applied to geothermal wells $\ldots \ldots \ldots \ldots, 14$

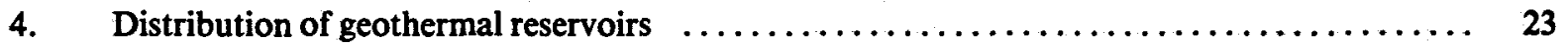

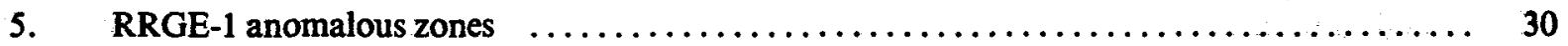

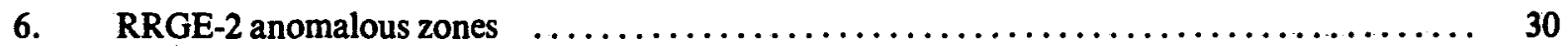

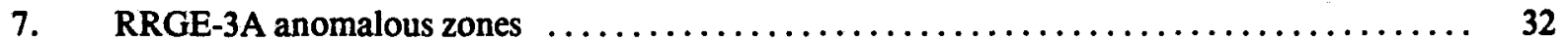

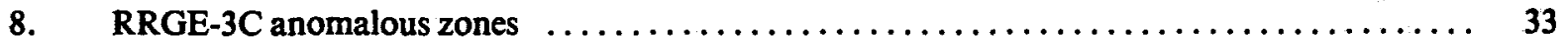

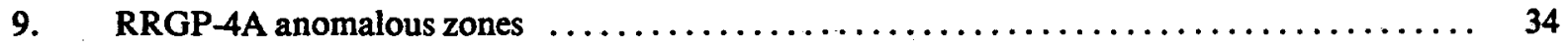

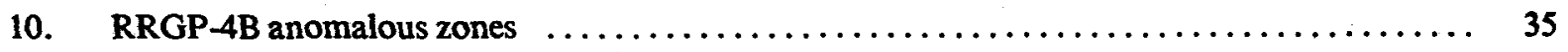

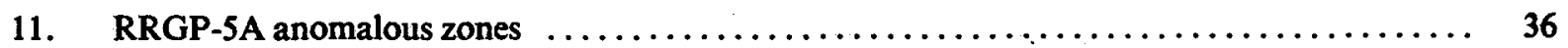

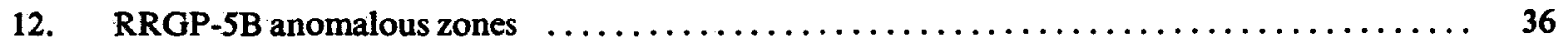

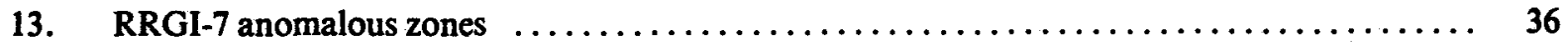

14. Lithologic indications from logs on RRGE-2 $\ldots \ldots \ldots \ldots \ldots \ldots \ldots \ldots \ldots \ldots \ldots \ldots .40$

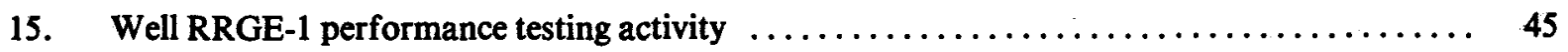

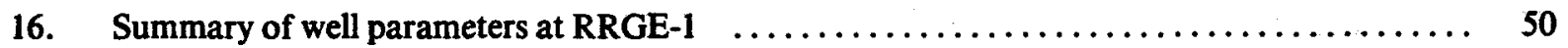

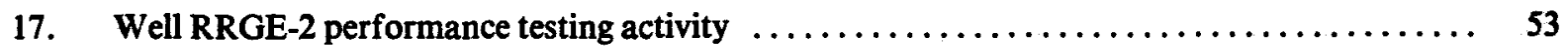

18. Summary of well parameters resulting from pulse testing at RRGE-2 $\ldots \ldots \ldots \ldots \ldots \ldots \ldots, 54$

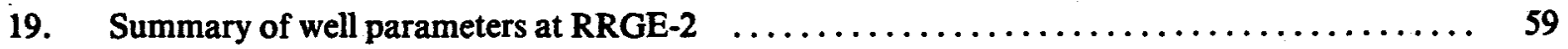

20. Well RRGE-3 performance testing activity $\ldots \ldots \ldots \ldots \ldots \ldots \ldots \ldots \ldots \ldots \ldots \ldots \ldots \ldots \ldots \ldots$

21. Summary of well parameters at well RRGE-3 $\ldots \ldots \ldots \ldots \ldots \ldots \ldots \ldots \ldots \ldots \ldots \ldots \ldots \ldots \ldots$ 


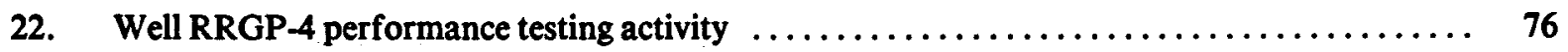

23. Well RRGP-5 performance testing activity $\ldots \ldots \ldots \ldots \ldots \ldots \ldots \ldots \ldots \ldots \ldots \ldots \ldots \ldots$

24. Summary of well parameters at RRGP-5 $\ldots \ldots \ldots \ldots \ldots \ldots \ldots \ldots \ldots \ldots \ldots \ldots \ldots$

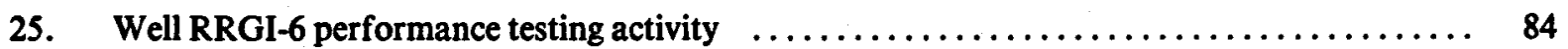

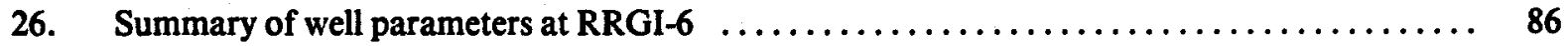

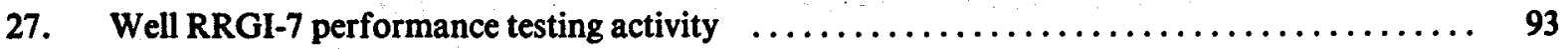

28. Summary of well parameters at RRGI-7 $\ldots \ldots \ldots \ldots \ldots \ldots \ldots \ldots \ldots \ldots \ldots \ldots \ldots$

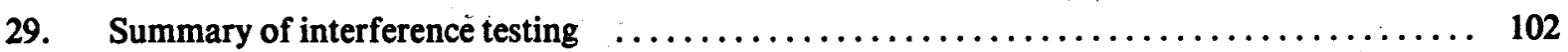

30. Summary of reservoir properties from interference data $\ldots \ldots \ldots \ldots \ldots \ldots \ldots \ldots \ldots$

31. Predicted pressure response $(\mathrm{kPa})$ at this end of 1 year $\left(\mathrm{t}_{1}\right)$ and
3 years $\left(\mathrm{t}_{3}\right)$ of operation, at $85 \%$ usage, in each well $\ldots \ldots \ldots \ldots \ldots \ldots \ldots \ldots \ldots \ldots \ldots \ldots \ldots$

32. Selected physical and chemical data from wells $\ldots \ldots \ldots \ldots \ldots \ldots \ldots \ldots \ldots \ldots \ldots \ldots$

33. Mixing fractions calculated from specific conductance $\ldots \ldots \ldots \ldots \ldots \ldots \ldots \ldots \ldots \ldots, 130$

34. Water compatibility for geothermal wells RRGE-1, RRGE-2,

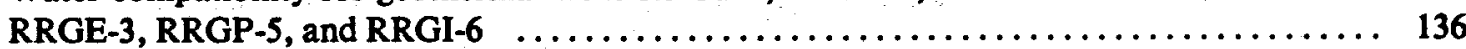

35. Particle size distributions of suspended solids in geothermal waters $\ldots \ldots \ldots \ldots \ldots \ldots \ldots, 138$ 


\section{METRIC-ENGLISH EQUIVALENTS}

The following conversion factors can be used to convert SI units (a modernized metric system) to English units.

\begin{tabular}{|c|c|c|}
\hline & SI Unit & English Unit \\
\hline Length & $\begin{array}{l}\text { millimeter (mm) } \\
\text { meter }(\mathrm{m})\end{array}$ & $\begin{array}{l}0.039 \text { inch (in.) } \\
3.28 \text { feet (ft) }\end{array}$ \\
\hline Volume & $\begin{array}{l}\text { liter }(L) \\
\text { liter/second }(L / s)\end{array}$ & $\begin{array}{l}0.2642 \text { gallons }(\mathrm{g}) \\
15.85 \text { gallons/minute }(\mathrm{gpm})\end{array}$ \\
\hline Mass & kilograms (kg) & 2.205 pounds (lb) \\
\hline Pressure & kilopascal (kPa) & 0.145 pounds $/$ inch $^{2}$ (psi) \\
\hline Temperature & Celsius $\left({ }^{\circ} \mathrm{C}\right)$ & $\frac{\left[\text { Fahrenheit }\left({ }^{\circ} \mathrm{F}\right)-32\right]}{1.8}$ \\
\hline
\end{tabular}




\section{SUMMARY}

The Management Plan for the 5MW(e) Power Plant outlined eight research objectives that would be achieved in the pilot plant start-up and operation. One major objective was to "gather data on reservoir deliverability and longevity." A program objective of the Geoscience Program is to develop an understanding of a typical fracture-controlled, liquid-dominated, moderate-temperature hydrothermal system by using the Raft River field as a case study area. This objective is addressed in this report which is an effort of EG\&G Idaho, Inc. to present the geoscience information derived from Raft River KGRA prior to power plant startup. The USGS is also publishing a professional paper to detail their geoscience efforts and studies, particularly those involved with exploration.

The geology, geophysics (borehole), hydrology, and geochemistry of the Raft River Geothermal Site are discussed in this report. The geology, geophysics, and geochemistry sections deal with resource characterization, while the hydrology section deals with the reservoir characterization. These sections are supported by appendixes on lithology, cores, $\mathrm{x}$-ray analysis, well construction, borehole geophysical logs, and chemical analyses. We hope that this report, coupled with the future USGS professional paper, will present a comprehensive picture of the geoscience work performed at the Raft River Geothermal Site. 



\section{RAFT RIVER GEOSCIENCE CASE STUDY}

\section{INTRODUCTION AND BACKGROUND}

An important part of the Raft River 5MW(e) Pilot Plant is the Supply and Injection System, an integrated network of production and injection wells designed to supply the power plant with moderatetemperature geothermal fluid. This network is composed of three designated production wells: one backup production well, two injection wells, and one deep well whose production was too low for pipeline connection. This report details the geoscience data on the Supply and Injection System accumulated and interpreted by the Idaho National Engineering Laboratory (INEL) from the period 1975 to 1981 .

After a period of extensive study, ${ }^{1}$ in late 1974 and early 1975 , a cooperative venture was initiated by the Department of Energy's (formerly Energy Research and Development Agency) Idaho Operations Office (DOE-ID), the Raft River Rural Electrical Cooperative, and the Idaho Department of Water Resources (IDWR) to drill a geothermal exploration well in the Southern Raft River Valley of Idaho.

The United States Geological Survey (USGS) was involved in technical direction, well siting, and exploratory direction. An integrated geologic, geophysical, and hydrologic exploration program was conducted by the USGS in 1973-1974, to locate the first well. 2 This well was spudded between two shallow boiling water wells located along the southwest alluvial fan of the Jim Sage Mountains. A key factor in placing this well was the anticipated interception, at depth, of the Bridge Fault.

The Raft River geothermal exploration well No. 1 (RRGE-1) was tested and encountered $146^{\circ} \mathrm{C}$ bottomhole temperatures with an artesian flow. Drilling on RRGE-1 terminated on April 1, 1975 at a TD of $1521 \mathrm{~m}$, approximately $152 \mathrm{~m}$ into the basement rock. 3,4 This well verified the existence of a hydrothermal resource approaching $150^{\circ} \mathrm{C}$ of low salinity fluid. The major production zone in RRGE-1 was found from 1128 to $1372 \mathrm{~m}$. (See Figure 1 for well field locations.)

After drilling was completed at RRGE-1, plans were made to drill RRGE-2, which was spudded April 26, 1975.5 It too was designed to intercept the Bridge Fault at depth. Drilling terminated June 26, 1975 at a TD of $1825 \mathrm{~m}$, over $300 \mathrm{~m}$ into the Precambrian basement rock. ${ }^{3,5}$ The major production zone was from 1295 to $1463 \mathrm{~m}$. Fracturing from 1524 to $1585 \mathrm{~m}$ contributed little to the artesian flow of this well.

After a period of flow testing wells RRGE-1 and RRGE-2 (under the direction of Lawrence Berkeley Laboratory), the RRGE-2 well was injection tested for about five months. In March 1976, upon the recommendation of the USGS, the RRGE-2 well was deepened to TD of $1994 \mathrm{~m}$ in the hard adamellite (quartzmonzonite) basement rock. No major fractured sections were observed in this basement section, and no significant increase in flow was noted.

The RRGE-3 well was spudded $2743 \mathrm{~m}$ southeast of RRGE-2 on March 28, 1976. This location was recommended by the USGS to determine if the resource extended outside the known fault zones into the center of the valley. This well was planned to have three directionally drilled legs in the lower portion of the well to determine if well costs could be reduced while increasing production. 6 The deepest leg, drilled to the north at a TD of $1804 \mathrm{~m}$, encountered the highest flow rate of the three legs. The maximum formation temperature was $150^{\circ} \mathrm{C}$, but the total artesian flow from the three legs was lower than the flow encountered in either the RRGE-1 or RRGE-2 wells.

Based upon early drilling experience, particularly the presence of a permeable zone encountered around $488 \mathrm{~m}$ to $915 \mathrm{~m}$ in RRGE-1 and RRGE-3, the fourth geothermal well, RRGI-4, was drilled for use as an experimental injection well. The well was spudded April 8, 1977 and drilled to a depth of $866 \mathrm{~m}$, open hole from $580 \mathrm{~m}$ to TD. 


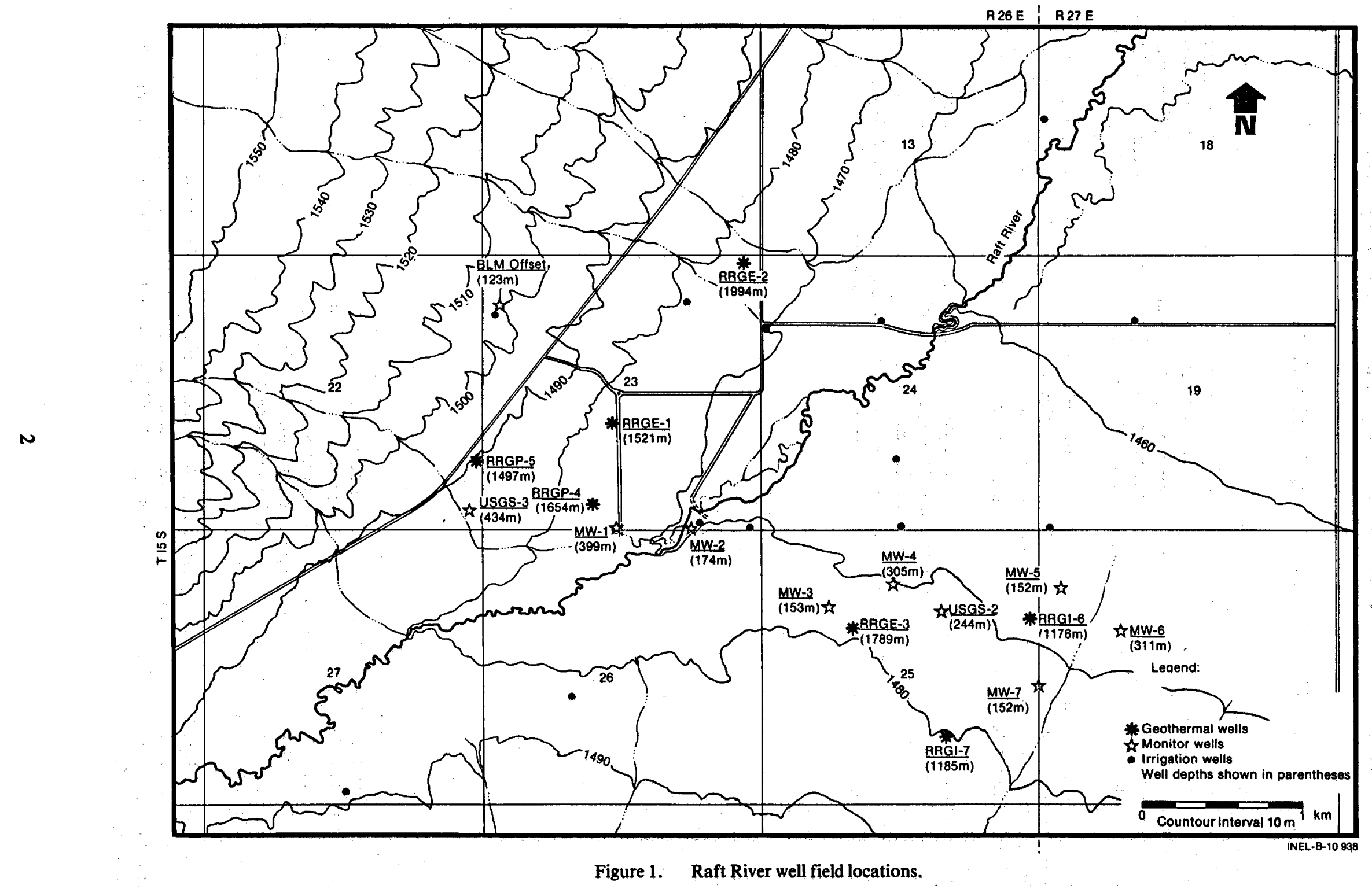


Detailed injection testing in the spring of 1978 revealed significant pressure response in nearby monitor wells, MW-1, USGS-3 and BLM Offset. ${ }^{7,8}$ This response suggested hydraulic connection between the near surface and injection zone at this location, and suggested that long-term injection into RRGI-4 would create a major impact.

After testing RRGI-4, decisions were made to inject into a deeper zone in the area of the RRGE-3 well. The RRGI-6 well was spudded April 12,1978 and drilled to a depth of $1172 \mathrm{~m} . .^{9}$ Open hole was left from $518 \mathrm{~m}$ to TD, leaving a large section available for injection. Preliminary testing suggested that RRGI-6 had large well losses, but would probably accept about $53.6 \mathrm{~L} / \mathrm{s}$. The rig was moved from here to drill a production well, RRGP-5, on the west side of the field.

Although evident from the drilling of RRGE-1 and -2 , and by the time RRGE-3 was completed, it became obvious that the Raft River reservoir was fracture-controlled. Matrix permeability was found to be a minimal contributor to hydrothermal flow; the RRGE-3 well, located on the valley floor, had relatively fewer fractures and produced less than the first two wells. Accordingly, well RRGP-5 was drilled along the southeast flank of the Jim Sage Mountains with hopes of again intercepting the Horse Well and/or Bridge Fault systems at depth.

During drilling of the RRGP-5 well, the drill pipe was lost, whereupon salt was used to control the artesian flow of the well. Upon recovery of the drill pipe, it was necessary to flush salt from the wellbore to avoid contamination of near surface aquifers. While this flush was in progress, the rig was moved to drill the RRGI-7 well. When operations on RRGP-5 started again, the well was drilled deeper, cased, and tested. (A deviated hole resulted because of difficulty in drilling through the bridge plug.) The test resulted in a disappointing flow and temperature in RRGP-5.

The RRGI-7 well was drilled $700 \mathrm{~m}$ southwest of the RRGI-6 and was nearly identical in well construction. It was cased to $622 \mathrm{~m}$, with open hole from there to $1172 \mathrm{~m}$.

Drilling activity at Raft River was concluded in late 1978 with the deepening of the RRGI-4 well into a production well (RRGP-4). The well was planned as a triple-legged well, but due to poor flows and funding constraints in drilling the initial two legs, the plans for a third leg were dropped. Legs drilled to $1652 \mathrm{~m}$ (Leg A) and $1558 \mathrm{~m}(\mathrm{Leg} \mathrm{B})^{10}$ produced less than $3.2 \mathrm{~L} / \mathrm{s}$ on an artesian test.

In August 1979, Leg B of well RRGP-4 was cased to $1433 \mathrm{~m}$ by Republic Geothermal Inc., sanded off from $1494 \mathrm{~m}$ to $1558 \mathrm{~m}$, and hydraulically fractured. This stimulation, the first known treatment of a geothermal well in the world to be hydraulically fractured, consisted of pumping $1.276 \times 10^{6} \mathrm{~L}$ of guar and polymer-treated water with $49,169 \mathrm{~kg}$ of sand at rates up to $137.8 \mathrm{~L} / \mathrm{s}$. After the treatment, the well was tested at artesian rates ranging from 3.8 to $14.2 \mathrm{~L} / \mathrm{s}$. A fracture treatment was also performed on RRGP-5 in November 1979. 


\section{GEOLOGY OF THE RAFT RIVER GEOTHERMAL SITE}

\subsection{Introduction}

The Raft River Valley in south-central Idaho is a Cenozoic basin bound on the east by the Black Pine Mountains and the Sublett Range, on the west by the Jim Sage and Cotteret Mountains, and on the south by the Raft River Range. The valley opens onto the Snake River Plain to the north as shown in Figure 2. The Raft River enters the basin at the south end of the Jim Sage Mountains and flows northward. The Known Geothermal Resource Area (KGRA) is located at the south end of the valley very near the IdahoUtah border. The present topography near the KGRA is characterized by coalescing alluvial fans and pediments fringing the flood plain of the Raft River.

The ranges surrounding the KGRA vary compositionally and structurally. They are described in this section because they provide a regional geologic perspective. The Sublett Range and Cotterel Mountains are omitted from this description since they have little known direct influence on the geothermal resource.

\subsection{Black Pine Mountains}

The Black Pine Mountains bound the east side of the valley. They are $27 \mathrm{~km}$ long and rise $1195 \mathrm{~m}$ above the valley floor. They are composed of a sequence of Late Paleozoic marine sediments, minor Tertiary volcanic sediments, and minor Quaternary alluvial and colluvial sediments. The exact thicknesses and sequences of the formations are difficult to determine because of the tectonic nature of many unit boundaries. 11 The lithology consists of the Devonian Jefferson Formation, the Mississippian Milligan Formation, and White Knob Formation, an undifferentiated Pennsylvanian unit, Tertiary age tuffaceous sediments, and Quaternary age sediments of the Lake Bonneville group. Low-grade contact and tectonic metamorphism is present in a few local outcrops. 11

The structure in this mountain range exhibits high angle Basin-and-Range normal faulting superimposed on older folds and thrust faults associated with Laramide tectonism. Thrust faulting has moved younger strata over older. 11

\subsection{Jim Sage Mountains}

The Jim Sage Mountains bound the west side of the valley. They are $29 \mathrm{~km}$ long and rise $667 \mathrm{~m}$ above the valley floor. Two small blocks are separated from the south end of the range by an inferred right-lateral strike-slip fault. 12

The range is composed entirely of the Tertiary Salt Lake Formation. The upper member of the formation is gray to light-green tuffaceous siltstone and sandstone with minor conglomerate composed of clasts of quartzite, dolomite, limestone, schist, and rhyolite. The middle member is composed of rhyolite flows, tuffaceous siltstone, and vitrophere breccia. The lower member is gray to white, thin-bedded to massive, tuff and tuffaceous sandstone; white to light-green shale and siltstone; and sparse beds of fine-grained conglomerate. ${ }^{2}$

The Jim Sage Mountains are structurally simple. The range is a tilted antiform block; the crest, near the eastern margin, creates steep scarps facing east and a gentle slope facing west. ${ }^{13}$ Steep normal faults located along the range fronts are attributed to Basin-and-Range tensional forces.

\subsection{Raft River Range}

The Raft River Range forms the southern boundary of the valley. It is $40 \mathrm{~km}$ long, rises $1250 \mathrm{~m}$ above the valley floor, and is the only east-west trending range in the area. 


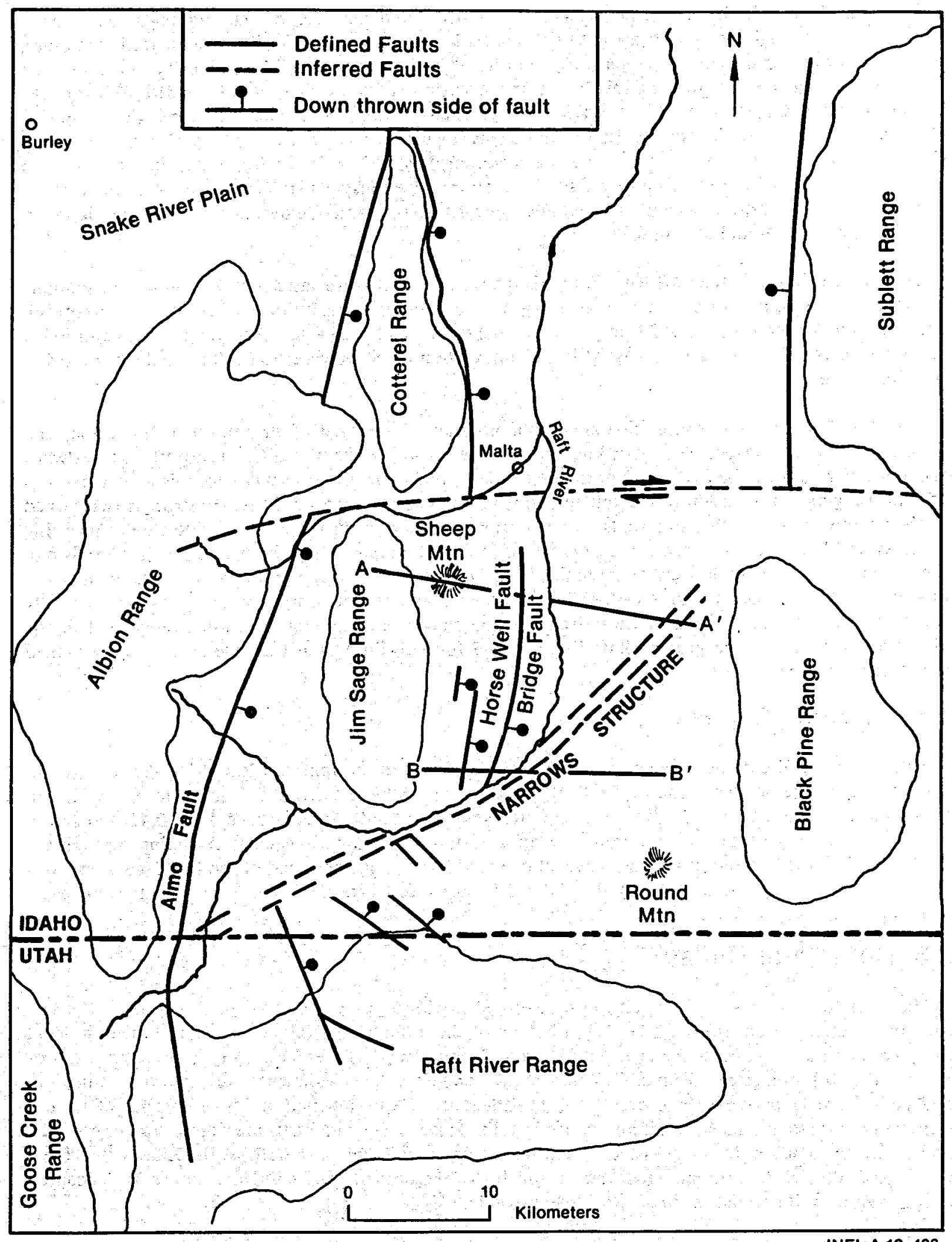

INEL-A-19 436

Figure 2. Raft River Valley and major structural features adjoining the valley. 
Stratigraphic units in the range have been highly deformed and metamorphosed, thinning and eroding in many areas. Although many units are cut by thrust faults, younger formations were emplaced over older, so that the stratigraphic sequence is generally in order. ${ }^{14}$ The Precambrian lithology of the range, in order by decreasing age, consists of the Older Schist, metamorphosed Adamellite, Elba Quartzite, Schist of the Upper Narrows, Quartzite of Yost, and Schist of Stevens Springs. Overlying these are: the Cambrian Quartzite of Clarks Basin and Schist of Mahogany Peaks; the Ordovician metamorphosed Pogonip Group, metamorphosed Eureka Quartzite and metamorphosed Fish Haven Dolomite; the Mississippian metamorphosed Chainman or Diamond Peak Formation; the Pennsylvanian Oquirrh Formation; Tertiary age mudstone, sandstone, conglomerate, and igneous rocks; and Quaternary age stream deposits, landslides, colluvium and alluvium. ${ }^{14}$

The metamorphism in the Raft River Range is the type normally associated with Precambrian metamorphism of the region; however, here it is apparently of Tertiary age. ${ }^{14}$ Two stages of metamorphism occurred; the first ended $38.2 \pm 2.0 \mathrm{~m}$.y. ago and the second ended $24.9 \pm 0.6 \mathrm{~m}$.y. ago. 15 Metamorphic grade increases downward and westward in the autochthon (Precambrian Adamellite) and downward in the allochthons.

The Raft River Range exposes two allochthonous sheets composed of Precambrian, Paleozoic, and Triassic sediments transported tens of kilometers along low-angle thrust faults. Transport was westward and northward during the two stages of metamorphism, and eastward after metamorphism. 15 Three sets of folds ranging from upright to recumbent formed during metamorphism. Most are strongly overturned to the northwest. A fourth set of folds, formed after metamorphism, vary in form and trend suggesting complex and localized movement. The orientation of these folds, and some high-grade metamorphism in the allochthons overlying low-grade metamorphism in the autochthons, is evidence of the later eastward movement of the thrust sheets. 15 Deformation in the range was caused by gravity gliding on a broadly heated dome. The crest of the dome shifted position causing the varying directional movement of the allochthonous sheets. The present Raft River Range formed during the Pliocene as a broadly arched anticline oriented east-west.

\subsection{Rhyolite Domes}

Two small rhyolite domes have been intruded and exposed in the southern Raft River Valley. Round Mountain near the northeast end of the Raft River Range has been dated at $8.3 \pm 1.7 \mathrm{~m}$.y., and Sheep Mountain on the east side of the Jim Sage Mountains north of the KGRA has been dated $8.42 \pm 0.2 \mathrm{~m} . \mathrm{y}$. and $7.8 \pm 1.1 \mathrm{~m} . y .2$ The rhyolite domes lie on a northwest-trending lineament extending through the Curlew Pass at the east end of the Raft River Range and into the northern end of the Jim Sage Mountains (Figure 2). Several smaller rhyolite bodies lie on the northwest extension of the lineament from Sheep Mountain.

\subsection{Raft River Valley}

The Raft River Valley is a downdropped basin filled with sediments derived primarily from the surrounding mountain ranges (Table 1). The lithology of the basin at the KGRA has been studied in detail using chip cuttings and cores from the shallow and deep wells (see References 16 to 27). Descriptions of cores and well lithology are detailed in Appendix A. The uppermost sediments are Quaternary alluvium and colluvium. Underlying these deposits is the Pleistocene Raft Formation which consists of unconsolidated quartz sand and silt, tuff, and minor rhyolite gravels. The sediments are poorly sorted, angular, and reach up to $300 \mathrm{~m}$ in thickness. Chip cuttings from shallow monitor wells at the KGRA indicate a fluvial and alluvial depositional environment much like the present. The lenticular nature of deposition makes well-to-well correlation of sediments impossible. ${ }^{26}$

The Tertiary Salt Lake Formation underlying the Raft Formation is a lacustrine deposit up to $1600 \mathrm{~m}$ thick. No definitive break occurs between the Quaternary and Tertiary sediments; the division is based primarily upon the relative abundance of volcanic material which increases downward into the lacustrine deposits. 


\begin{tabular}{ll}
\hline Mountain Range & \multicolumn{1}{c}{ Detritus } \\
\cline { 2 - 2 } Sublett and Black Pine & Limestone and clastic rock fragments \\
Raft River and Albion & $\begin{array}{l}\text { Metamorphic and igneous rock fragments, undulatory } \\
\text { quartz, microcline, orthoclase }\end{array}$ \\
Jim Sage and Cotterell & $\begin{array}{l}\text { Volcanic rock fragments, nonundulatory quartz, } \\
\text { equant plagioclase, sanidine }\end{array}$
\end{tabular}

The lithology of the Salt Lake Formation in the basin consists of light green, thin-bedded to massive, tuffaceous siltstone and sandstone with minor conglomerates. ${ }^{25}$ The primary rock types in the Salt Lake Formation are shales, siltstone, sandstones, and tuff. The major and minor mineral constituents are given in Table 2.25 Quartz and feldspar are the most abundant minerals present. Quartz shows both undulatory and nonundulatory extinction in a thin section, indicating its origin from both metamorphosed and nonmetamorphosed sources.

Depositional and deformational sediment structures in the Salt Lake Formation can be seen in cores, thin sections, and outcrops. Shales and siltstones are thin-bedded to massive. Thin beds are 2 to $3 \mathrm{~mm}$ thick and are seldom graded. Massive beds occur primarily in the coarse-grained graywackes and are both normal and reverse-graded. 25

The most abundant deformational structures seen are microfaults, breccias, ball and pillow structures, and convolute laminations. These indicate rapid deposition and deformation of water-saturated sediments. Volcanic shocks may have produced the force necessary to cause rapid slumping of sediments and the formation of turbidites. 25

Hydrothermal alteration in both the Salt Lake Formation and the Raft Formation has resulted in: replacement of the primary calcite by silica; fracture filling by secondary calcite; clay mineral alteration; and the emplacement of secondary minerals, i.e., biotite and muscovite, and pyrite and other sulfides. ${ }^{28}$ Some of the secondary minerals found in thin sections from Raft River wells were formed by diagenetic processes rather than hydrothermal alteration. Hydrothermal alteration is more prevalent in the

\section{Table 2. Mineral constituents in the Salt Lake Formation}

Major Constituents

Quartz Plagioclase

Orthoclase

Microcline

Sanidine

Muscovite

Biotite

Pyrite
Ashy matrix

Clay matrix

Carbonate cement

Rock fragments

Zircon

Monazite

Epidote

Chlorite
Minor Constituents

Zeolites

Glass shards

Pumice lumps

Fossils

Apatite

Augite

Tridymite

Diopside

Hornblende

Garnet 
deeper sediments. Clays change downward from montmorillonite to illite, and zeolites change downward from clinoptilolite to laumontite. ${ }^{29}$ Deposition of calcite and silica is the dominant form of alteration near the bottom of the Tertiary sediments. Calcite fills the fractures, and the silica forms a "caprock" above the geothermal reservoir. 29

Fossils are rare in thin sections from the Raft River wells, but are found in Salt Lake Formation siltstones from well RRGP-5. The fossils are deformed from compaction making identification difficult, but appear to be ostracods and/or Pelecypods. The presence of organic material in this well indicates a depositional environment that is more oxygenated than other parts of the basin. Deposition was probably close to the lake shoreline. 25

The Salt Lake Formation unconformably overlies part of the Precambrian rock assemblage seen in the Raft River Range. The described formations, from youngest to oldest are present in the deep wells at Raft River. The Quartzite of Yost is a white quartzite with moderate muscovite and up to $10 \%$ K-feldspar. 30 Thin sections from this unit show calcite veining and carbonate cement in fractures. ${ }^{25}$ The unit is absent in wells RRGE-1 and RRGE-2. The Schist of the Upper Narrows is a dark-brown to gray, fine- to mediumgrained biotite schist and fine-grained gneiss containing quartz and quartz-feldspar lenses. ${ }^{30}$ The Elba Quartzite is a white, tan, or dark-green quartzite with interbeds of muscovite-quartz schist. 30 The Older Schist is a brown, mica-rich schist. The unit is absent in wells RRGE-1 and RRGE-2. The Adamellite is a light to dark green-gray quartz feldspathic gneiss with $\mathrm{K}$-feldspar porphyroblasts surrounded by cemented quartz with a trace of pyrite and magnetite. ${ }^{30}$ The Adamellite in the Raft River Valley and the Raft River Range is thought to be partially older than the overlying formations and partially remobilized and intruded. 2

The metasediments and adamallite basement rocks in the basin appear flat lying on reflection seismic sections with no major identifiable structures. ${ }^{31}$ Low-angle faults have probably thinned or erased the units, with movement related to that seen in the Raft River Range. The upper part of the allochthon seen in the Raft River Range, Cambrian through Mississippian units, are absent in this part of the valley.

\subsection{Geologic Structure}

The geologic structure of the Raft River Basin near the KGRA has been studied extensively using geophysical techniques, surface geological mapping, and aerial photography. Geophysical surveys run in the basin include: (a) gravity; (b) magnetic; (c) audio-magnetotellurics; (d) seismic reflection and refraction; (e) self-potential; (f) direct current resistivity; and (g) Schlumberger soundings and field measurements. (See References 2 and 32 to 41.)

The gross structure, as defined by gravity techniques, is a downdropped basin with steep normal faults inferred at the range fronts. ${ }^{2}$ The principal faults exposed at the surface lie in a north-trending zone on the west side of the valley called the Bridge Fault Zone. Gravity data indicate the zone is narrow on the east side of Sheep Mountain and has the greatest amount of vertical displacement at this location. South of Sheep Mountain the fault zone widens to the west and distributes vertical displacement between a series of normal faults trending slightly east of north. Surface dip of the faults is 60 to $70^{\circ}$. The early interpretation 42 of the Bridge fault zone shows continued steep dips to depth, displacing the metasediments and quartz monzonite basement rocks (Figure 3a). A later interpretation 29 infers a shallowing of dip with depth, flattening to parallel the bottom of the Tertiary sediments, with no displacement of the basement (Figure 36 ). Covington 29 postulates that movement on the concave upward faults produced many near vertical open fractures and cracks near the base of the Tertiary sediments.

Gravity data show additional normal faulting on the west side of the Bridge Fault Zone. ${ }^{42}$ This Horse Well Fault Zone (Figure 3b) closely approximates the Bridge Zone in strike and dip. 29

The Bridge and Horse Well Fault Zones are terminated north of the Raft River by a poorly understood geologic structure called the Narrows Zone. This structure trends to the northeast across the basin and is 


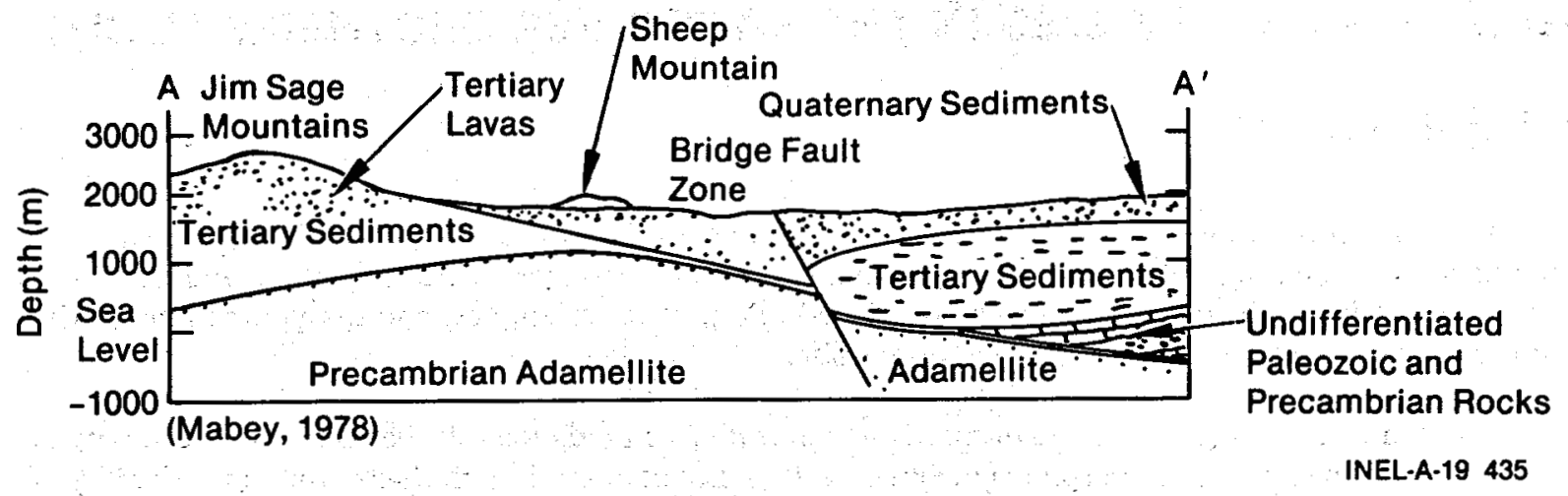

Figure 3a. An early interpretation of the Bridge Fault Zone.

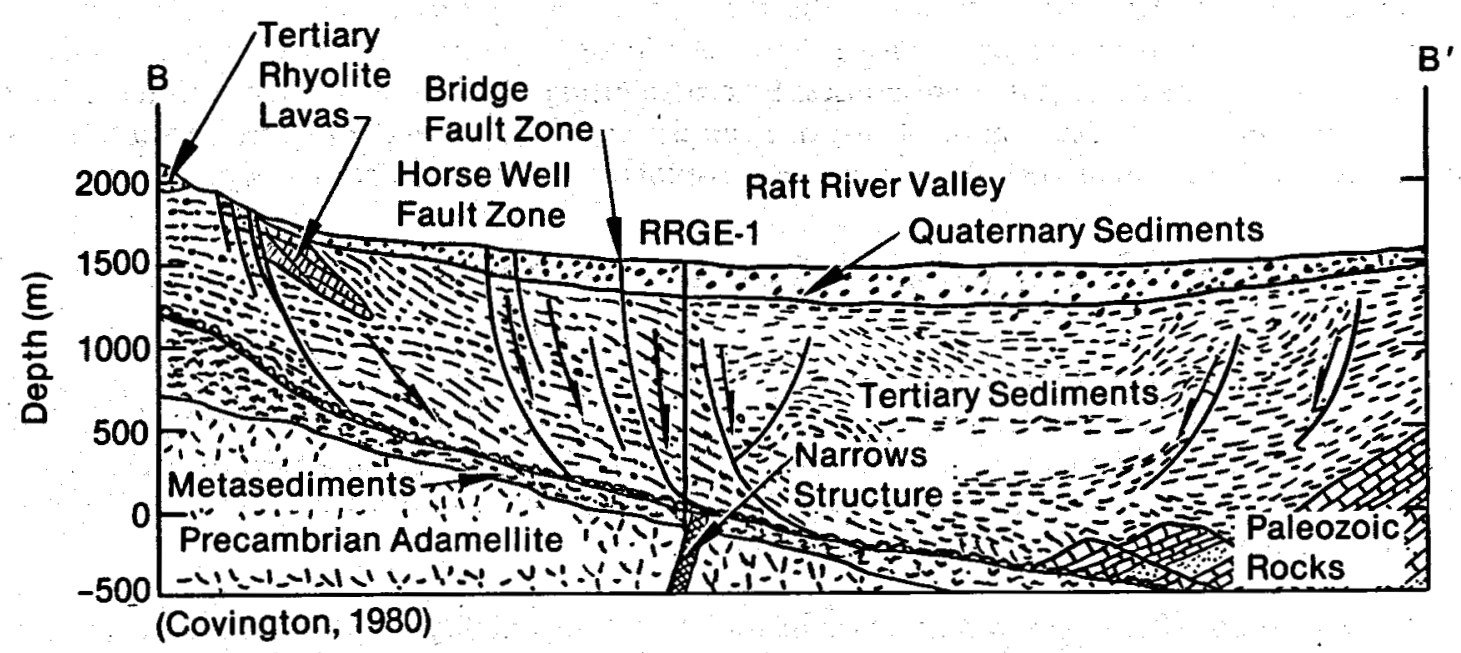

Figure 3b. A later interpretation of the Bridge Fault Zone illustrating no displacement of the basement.

thought to be a basement shear associated with a large regional feature called the Humboldt Zone. 42 The Narrows Zone is inferred by a compilation of anomalous data from geophysical surveys that suggest major changes occurring in a northeast trend. 42

\subsection{Conclusions}

The geothermal system in the Raft River Basin occurs at the intersection of the Narrows Zone and the Bridge Fault Zone. Hydrothermal water is believed to circulate to depth along basement fractures, possibly along the southwest extension of the Narrows Zone, then rises at the intersection of the two major structures where it spreads laterally into the Tertiary sediments. Upward leakage through fractures in the Salt Lake Formation provides hot water to the shallow hot wells in the valley (Crook and BLM wells). No evidence of a local heat source is apparent. 42 


\section{GEOPHYSICS OF WELLS IN THE RAFT RIVER GEOTHERMAL SITE}

\subsection{Introduction}

A borehole geophysical review of the Raft River Geothermal Site consisted of gathering all relevant and obtainable well and supplemental data; evaluating the data for completeness, quality, and accuracy; analyzing the data, where possible; using established interpretive techniques; and developing interpretive models applicable to the Raft River Geothermal Site.

The wells at the Site were evaluated primarily to delineate fractured intervals, because with the variety of rock types (sedimentary, metamorphic, igneous); the presence of alteration products; and the variability of fracturing; conventional interpretive techniques for identifying lithology porosities and permeabilities are not always reliable. As an example, log responses to the igneous and metamorphic lithologies at the Site make it impossible to determine matrix densities and velocities. Consequently, porosities and permeabilities cannot be calculated. Therefore, the interpretive technique used was to identify fractures using diagnostic indicators from the logs, to note characteristic log responses, and to attempt to understand the geological parameters causing these responses. By crossplotting these responses, the various rock types and matrix parameters were determined. Thus, one can determine the relevant data necessary to assess a geothermal reservoir in similar rock types and use crossplots to potentially define the producing zones.

\subsection{The Logging Program and Fracture Identification}

A relatively complete suite of logs were run on all seven wells. The log suites varied slightly depending on the service company and the specific logging program. The basic suite included the following logs: induction, acoustic, density, neutron, caliper, the Spontaneous Potential curve (SP), and temperature. Wells 1, $4,5,6$, and 7 were digitized and stored on magnetic tape. Appendix $C$ identifies all seven Raft River wells and outlines the type of logs run, the date, and depth.

3.2.1 Induction Log. Resistivity is a measure of the formation's ability to impede the flow of current and is measured in ohm-meters. The dual induction log measures three depths of investigation. The shallow reading curve (laterlog 8) measures the resistance of the invaded area around the borehole. The deep induction curve measures the entire formation's resistivity and must be corrected for borehole size, fluid resistivity, and tool stand-off. The medium induction curve is the same as the deep induction curve and is focused to respond to depths shallower than those for the deep induction.

3.2. 1.1 Geothermal Applicability - The dual induction log indicates the presence of fractures if the laterlog 8 reads less than the deep induction curve. ${ }^{43}$ The laterlog 8 is a vertically focused, short-spaced resistivity tool that may respond to thin-bedded formations and/or to vertical fractures when they are filled with filtrate of resistivity lower than that of the formation. The deep induction log reads horizontal conductivity, which is presented in the induction $\log$ as the inverse, i.e., as resistivity $\left(R_{i} L\right)$. Consequently, the presence of fractures in the wall of a borehole might be detected if the laterlog 8 indicates less resistivity than the deep induction log.

3.2.1.2 Induction Log Drawback-In massive crystalline rocks, the formation resistivity is usually high (100 $\Omega$ or greater). This high resistance causes the dual induction curves to saturate, and accurate resistivity readings cannot be obtained. In these cases, as in Raft River wells 2, 3, and 5, the dual laterlog resistivity tool should have been used.

3.2.2 SP Curve. The Spontaneous Potential curve (SP) is a measure of the naturally occurring formation potential due to the drilling of the borehole. The SP curve can distinguish between sands and shales and can be used to qualitatively identify porosity and permeability. With the help of the SP, the resistivity of the formation waters may also be determined. 
3.2.2.1 Geothermal Applicability - The SP curve does develop in some naturally fractured reservoirs and can be used qualitatively to determine the presence of fractures. 44 In fact, the SP curve tends to be hachured where each SP spike most likely corresponds to a streaming potential effect, resulting from mud filtrate invasion into the fractures. 45

3.2.2.2 SP Drawback-Igneous and metamorphic rocks do not generally display a self-potential.

3.2.3 Acoustic, Density, and Neutron Logs. These logs are used to identify the porosity and lithology of a formation.

3.2.3.1 Geothermal Applicability-From the Litho-porosity cross-plot interpretive technique, vuggy, and/or fractured zones can sometimes be detected. This technique was introduced to help interpret formations with complex lithologies. The method handles the data from density, neutron, and acoustic logs simultaneously. From the reading of these logs, two porosity-independent parameters, $\mathrm{M}$ and $\mathrm{N}$ can be determined as follows:

$$
\begin{aligned}
& M=\frac{\Delta t_{f}-\Delta t}{\rho_{b}-\rho_{f}} \times 0.01 \\
& N=\frac{(\phi N)_{f}-\phi N}{\rho_{b}-\rho_{f}}
\end{aligned}
$$

In the crossplot of $\mathbf{M}$ versus $\mathbf{N}$, each pure mineral is represented by a unique point regardless of porosity. For complex lithologies, the position of the data points on the M-N plot (Figure 4) helps identify the various minerals in the formation, and the approximate percentage of each one.

By assuming that the acoustic log responds to only matrix porosity, and the neutron and density logs respond to total porosity [Equation (2)], the secondary porosity does not affect the value of $N$. Analysis of Equation (1), however, reveals that the value of $M$ increases as the secondary porosity increases. See Figure 4. Consequently, the crossplot of $\mathrm{M}$ versus $\mathrm{N}$ allows the detection of vuggy and/or fractured zones.

Fracture identification may also be obtained from the correction curve $(\Delta \mathrm{P})$ on the compensated density $\log .{ }^{46}$ Since the $\Delta \mathrm{P}$ curve corrects the density logs for effects of rough borehole and mud cake, the $\Delta \mathrm{P}$ may be affected by the mud in the fracture and indicate a correction even if the hole is in gauge.

3.2.3.2 Porosity Log Drawbacks - In the majority of igneous and metamorphic rocks, the matrix parameters, i.e., the matrix density and travel time, are difficult if not impossible to determine.

3.2.4 Caliper Log. The main function of the caliper $\log$ is to determine borehole size. Secondary functions include determining mud cake build-up and bit-wear.

3.2.4.1 Geothermal Applicability-A sensitive, four-arm caliper can quite often detect fractures by showing hole enlargement. When there is an inclined fracture, the hole usually becomes noncircular in crosssections, due to preferential hole enlargement in the direction of the fracture. A three-arm caliper gives an average diameter of the borehole. On the other hand, the one-arm caliper with a pad-mounted device, such as the density tool, tends to give the maximum width of the borehole. This is so because the caliper arm in such a tool is pressed very hard against the borehole wall and when the tool is pulled up during logging, the caliper tends to align itself and extend in the direction of the maximum width. Thus, when comparing the one-arm caliper of the density tool with the three-arm caliper of the acoustic or borehole geometry (BG) tool, a fractured zone of the one-arm caliper will indicate a larger diameter than the three-arm tool.

3.2.5 Other Borehole Tools for Fracture Detection. Other borehole logs, such as the borehole televiewer, the temperature log, and the microseismogram can also be used to detect possible fractures. 


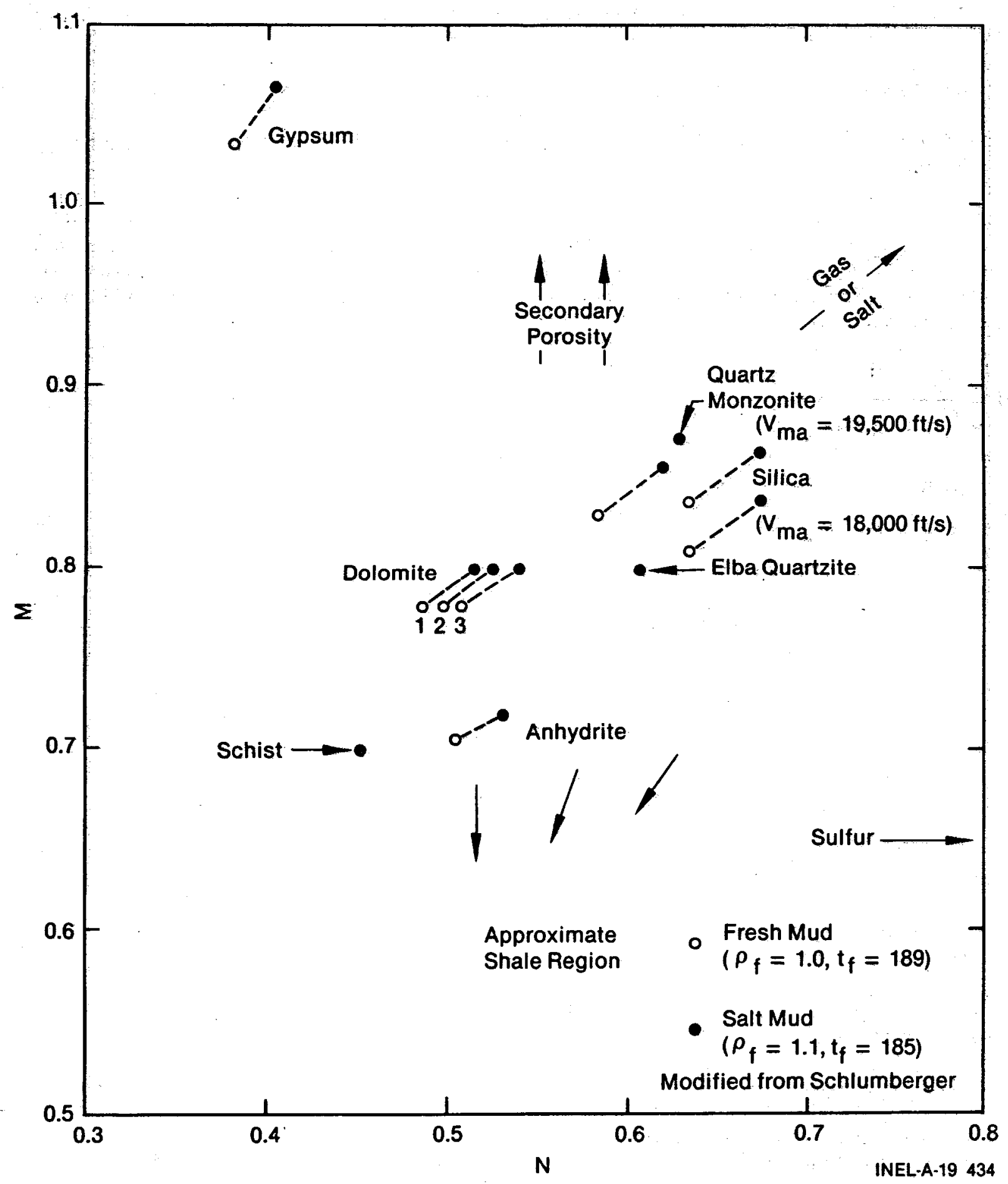

Figure 4. M-N crossplot with unique rock materials from Raft River. 
-The borehole televiewer (BHTV) takes an acoustic picture with a rotating ultrasonic scanner. 47 The log inspects the borehole and evaluates the formation as it reveals induced and natural fractures and/or vugs. The BHTV is not commercially available at this time; however, the United States Geological Survey (USGS) does have an experimental BHTV and has logged all seven Raft River Wells. ${ }^{48}$

The variable intensity log (Microseismogram) can also be used to detect fractures. This log-is presented commercially as a recording of depth versus the time after the initiation of an acoustic pulse at the transmitter. Amplitude changes are indicated by a succession of varying shades of gray across the film track. The darkest areas correspond to the largest positive negative amplitude. Raft River Exploration Well No. 2 (RRGE-2) was the only well in which a variable intensity log was run.

Temperature logs were used extensively in interpreting fractures at the Raft River. ${ }^{49}$ According to Stoker, 49 the Raft River water production is definitely not the result of homogeneous rock permeability, but is dependent on highly fractured zones within the formations. The temperature log, run under nonequilibrium conditions, has provided useful information about the characteristics and locations of the production zones.

The applicability of these logs are identified, along with the standard logging suite, in Table 3 . The fracture identification criteria, as outlined in this table, can be used as diagnostic indicators in determining fractures at the Raft River. Other diagnostic indicators of fracturing include: drilling rate, mud circulation data, drill cuttings data, and rock strength.

\subsection{Log Quality}

The majority of the logs were of reasonably good quality given the well bore conditions under which they were run, i.e., washed out holes and high-temperature conditions. The Raft River wells, the logs that were run, the depth of the wells, and the quality of the logs are identified in Figures 5 through 11 . Because logs are given in footage units, this group of figures is not in metrics. The majority of the problems with the logs can be broken into the following categories.

\subsubsection{Establishing a Definitive Logging Program}

1. In RRGE-2, -3, and RRGP-5, the dual laterlog should have been run.

2. In RRGE-1, a gamma ray was not run with the acoustic tool, even though this is standard industry practice and a definite aid in $\log$ correlation.

3. In many cases, the hole was washed out beyond the saturation limit of the caliper. The caliper arms should have been extended, and recalibrated for larger hole sizes.

4. In RRGE-2, the wrong gamma ray scales were used on the density log.

5. In RRGE-2, the gamma ray and the porosity curve were not run on the acoustic log.

6. In RRGP-5, the density and some scales were not compatible.

7. In RRGI-6, the curves were not properly identified, and in the case of the gamma ray, the log heading indicated that a gamma ray was run but no curve existed.

8. In RRGI-7, the sonic log did not have a caliper.

3.3.2 Tool Failure and Procedural Errors. In several of the Raft River wells, there were tool failures on primary logs, and consequently no data were obtained. This condition seriously affected the geophysical interpretation of those wells. When the logging program is established, backup tools for the primary logs should be requested. All the wells at Raft River had at least one log that, due to tool failure, was not obtained. 
Table 3. Limitations and special character of logging tools applied to geothermal wells

\begin{tabular}{|c|c|c|c|}
\hline Type of Log & $\begin{array}{l}\text { Primary Logging } \\
\text { Function }\end{array}$ & $\begin{array}{l}\text { Major Drawback in } \\
\text { Geothermal Logging }\end{array}$ & $\begin{array}{c}\text { Special Logging Applications } \\
\text { to Geothermal Environments } \\
\end{array}$ \\
\hline Resistivity & $\begin{array}{l}\text { Formation resistivity } \\
\text { Bed boundaries } \\
\text { Depth of invasion } \\
\text { Porosity }\end{array}$ & $\begin{array}{l}\text { Igneous rock usually displays } \\
\text { high resistivity. }\end{array}$ & $\begin{array}{l}\text { Reversal of resistivity curves } \\
\text { may indicate fractures. }\end{array}$ \\
\hline SP Curve & $\begin{array}{l}\text { Lithology } \\
\text { Formation water } \\
\text { resistivity }\end{array}$ & $\begin{array}{l}\text { Igneous rocks do not usually } \\
\text { display a self potential. }\end{array}$ & $\begin{array}{l}\text { Streaming potential may indi- } \\
\text { cate fracturing. }\end{array}$ \\
\hline Density & $\begin{array}{l}\text { Density } \\
\text { Porosity } \\
\text { Lithology }\end{array}$ & $\begin{array}{l}\text { Cannot identify matrix den- } \\
\text { sity in certain igneous meta- } \\
\text { morphic environments. }\end{array}$ & $\begin{array}{l}\text { Crossplot interpretation and } \\
\Delta p \text { corrections may iden- } \\
\text { tify fractures. }\end{array}$ \\
\hline Neutron & $\begin{array}{l}\text { Porosity } \\
\text { Lithology }\end{array}$ & $\begin{array}{l}\text { Cannot identify matrix } \\
\text { response to neutrons. }\end{array}$ & $\begin{array}{l}\text { Porosities are usually higher } \\
\text { in fractures. }\end{array}$ \\
\hline Sonic & Porosity & $\begin{array}{l}\text { Cannot identify matrix travel } \\
\text { times in certain igneous and } \\
\text { metamorphic environments. }\end{array}$ & $\begin{array}{l}\text { Amplitude reductions may indi- } \\
\text { cate fractured zones. }\end{array}$ \\
\hline Borehole Televiewer & $\begin{array}{l}\text { Identifies borehole } \\
\text { irregularities }\end{array}$ & $\begin{array}{l}\text { Equipment reliability hole } \\
\text { irregularities. }\end{array}$ & $\begin{array}{l}\text { Fractures can usually be } \\
\text { detected. }\end{array}$ \\
\hline Gamma Ray & $\begin{array}{l}\text { Lithology } \\
\text { Correlation }\end{array}$ & $\begin{array}{l}\text { Cannot be used as clay indi- } \\
\text { cators in igneous or metamor- } \\
\text { phic environments. }\end{array}$ & $\begin{array}{l}\text { Many igneous and metamorphic } \\
\text { rocks display natural radio- } \\
\text { activity. }\end{array}$ \\
\hline Caliper & Borehole size & $\begin{array}{l}\text { Holes are washed out when } \\
\text { drilled with water. }\end{array}$ & $\begin{array}{l}\text { Sensitive calipers can detect } \\
\text { fractures (often show hole } \\
\text { enlargements). }\end{array}$ \\
\hline Temperature & $\begin{array}{l}\text { Determine temperature } \\
\text { gradient }\end{array}$ & $\begin{array}{l}\text { Nonequilibrium well bore } \\
\text { condition may have to be } \\
\text { created. }\end{array}$ & $\begin{array}{l}\text { Fractured zones will display } \\
\text { temperature anomalies. }\end{array}$ \\
\hline
\end{tabular}




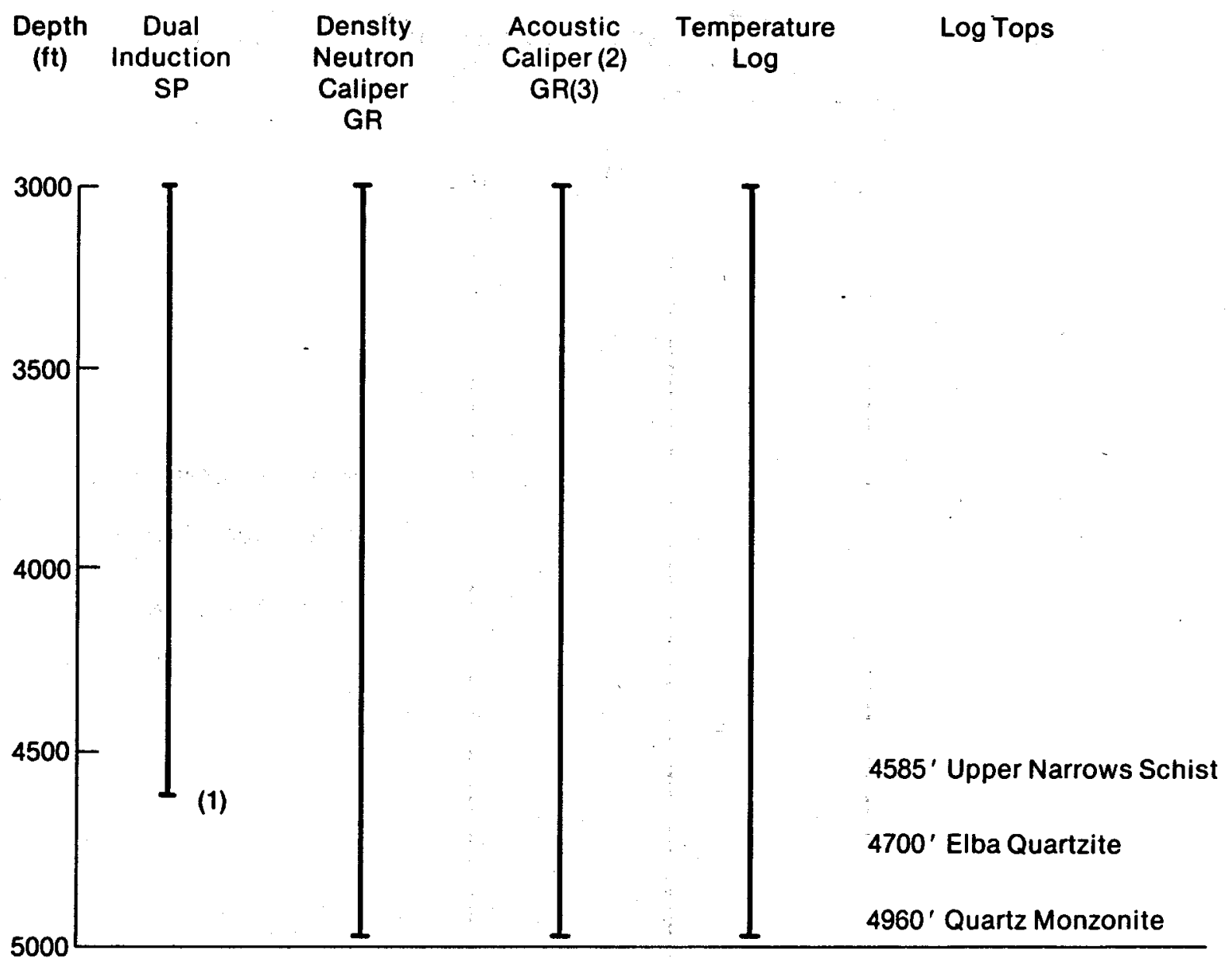

1) Dual induction not run on bottom $400^{\circ}$ of shale

2) Caliper tool failure

3) Gamma Ray not run

4) Borehole enlarged beyond 20 in. $-3722^{\prime}$ to $3872^{\prime}, 3964^{\prime}$ to $4026^{\prime}, 4096^{\prime}$ 'to $4144^{\prime}, 4338^{\prime}$ to $4420^{\prime}$ INEL-A-19 540

Figure 5. RRGE-1 log suite with notes on $\log$ quality. 


$\begin{array}{cccccc}\text { Depth } & \text { Dual } & \text { Density } & \text { Acoustic } & \text { Temperature } & \text { Log Tops } \\ \text { (ft) } & \begin{array}{c}\text { Induction } \\ \text { SP }\end{array} & \begin{array}{c}\text { Neutron } \\ \text { Caliper } \\ \text { GR }\end{array} & \begin{array}{c}\text { Caliper } \\ \text { GR }\end{array} & \text { Log } & \\ & & & & \end{array}$
(3) (4) (5)
(6)
(7)

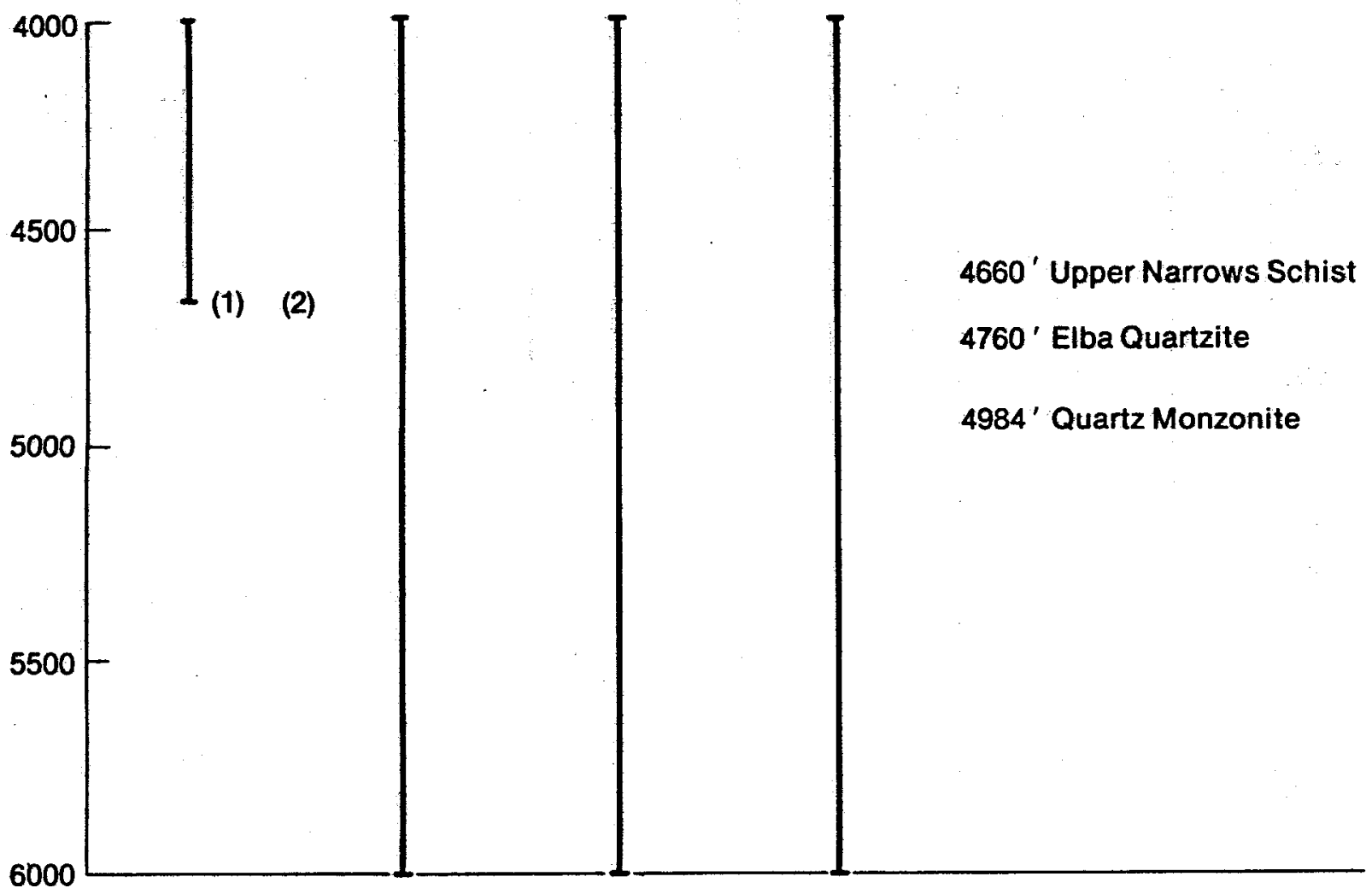

1) Dual induction curves saturated from $4670^{\prime}$ to TD. Curves are meaningless other than to denote high resistance

2) $\mathrm{SP}$ is drifting excessively

3) GR saturates at 340 API units over intervals from $5000^{\prime}$ to TD

4) Caliper is washed out in intervals from 4226 ' to $4700^{\prime}$ and in gauge from $5000^{\prime}$ to TD

5) Density and neutron were run on sandstone matrix

6) GR and acoustic porosity were not run

7) Caliper was traced from the density log

8) Acoustic reads $54 \mu \mathrm{sec}$ in casing

INEL-A-19 541

Figure 6. RRGE-2 log suite with notes on $\log$ quality. 


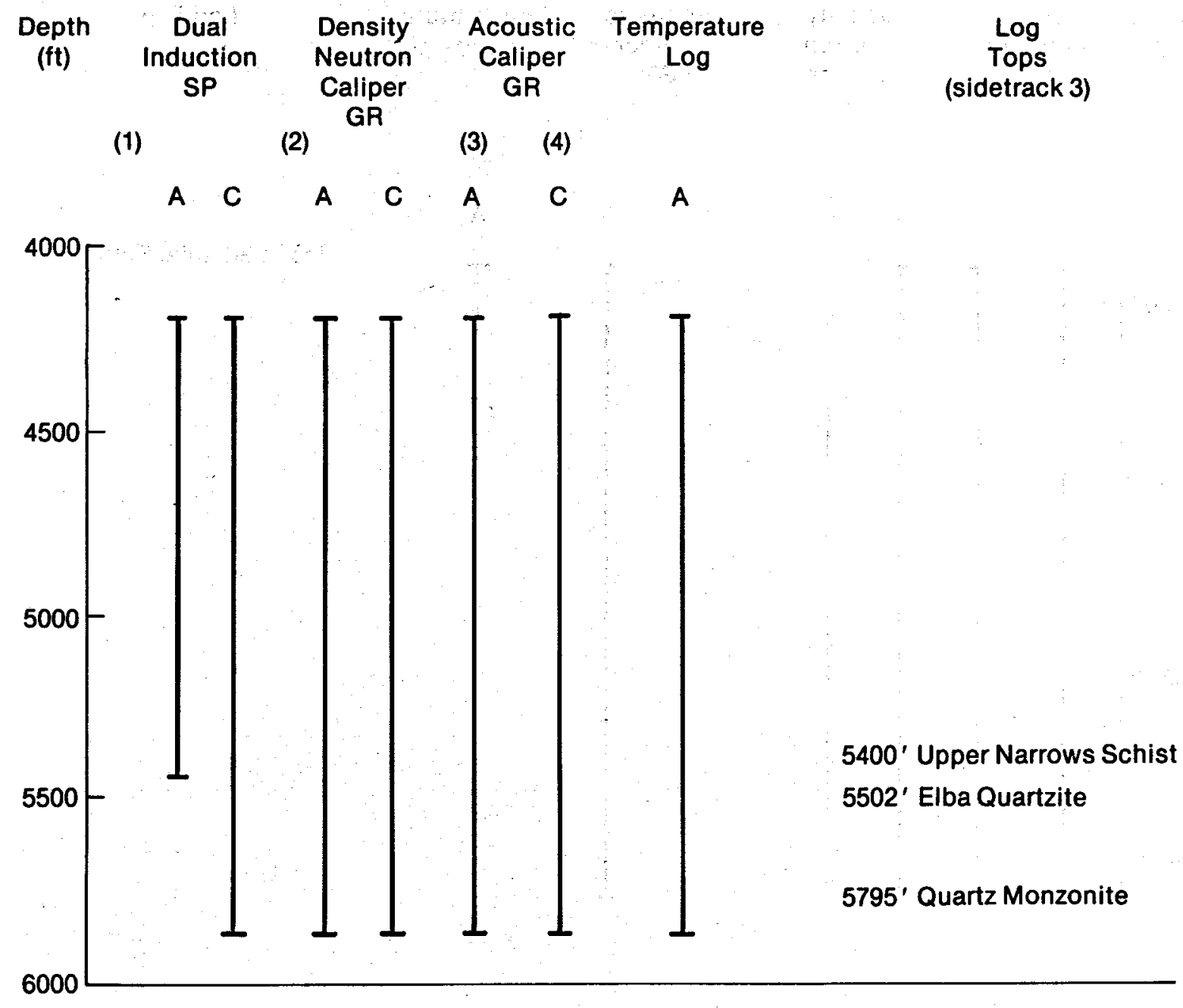

1) Dual induction unreadable below $5380^{\prime}$; SP off-scale from $5304^{\prime}$ to 5386 '

2) There is a 6-foot depth discrepency between density and neutron

3) Gamma ray not reading correctly

4) Acoustic is very noisy and reading very high porosity in tight rock; acoustic values are questionable

Figure 7. RRGE-3 log suite with notes on $\log$ quality. 


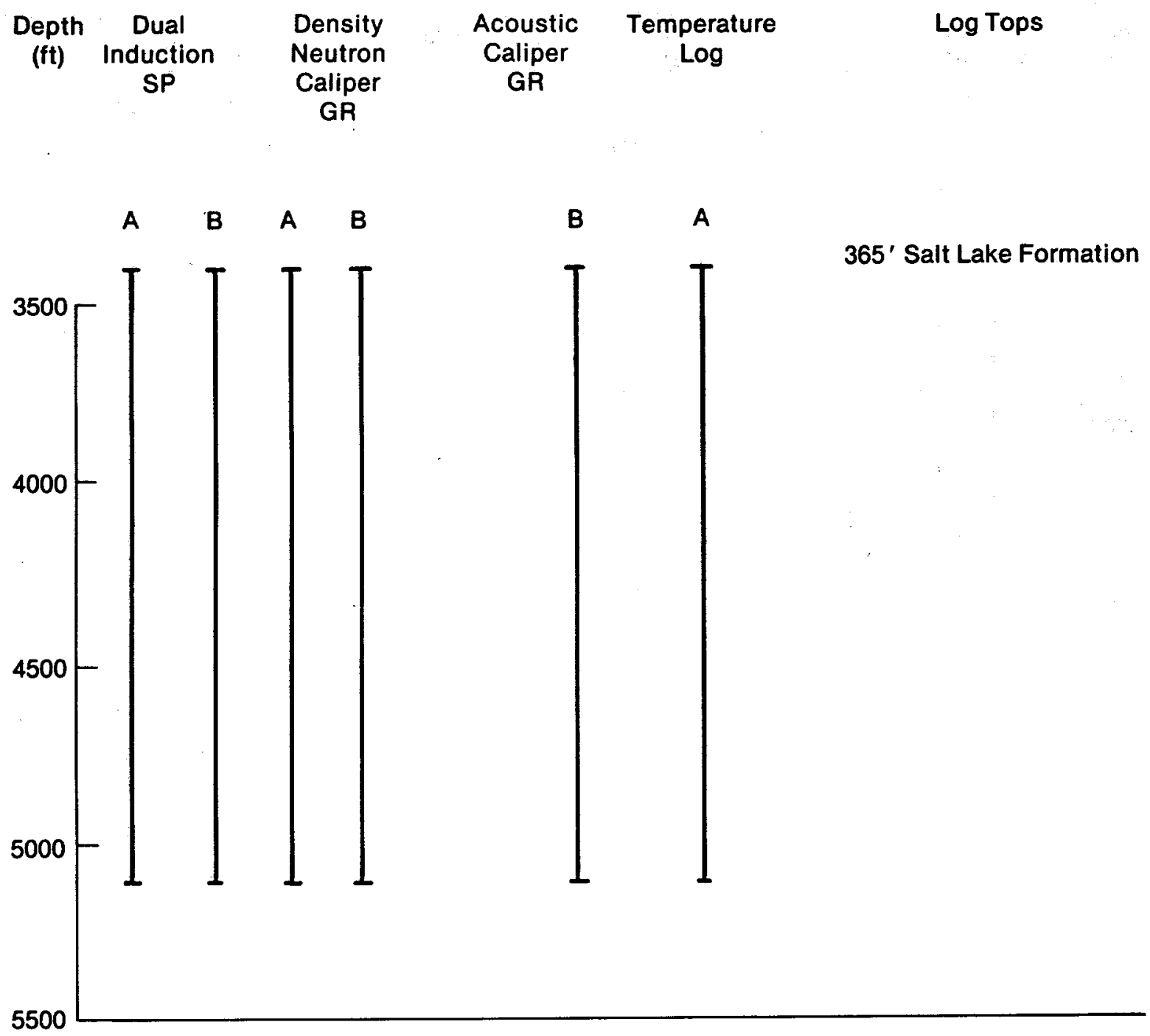

1) Caliper, GR, and acoustic on $\log A$ is not reading correctly

INEL-A-19 536

Figure 8. RRGP-4 $\log$ suite with notes on $\log$ quality. 


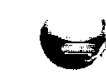

Depth Dual

(ft) Induction

Density

Neutron

SP

Caliper

Acoustic

Caliper

Temperature

Log

Log Tops

$\bullet$

(1) (2)

(3)

(4)

(5)

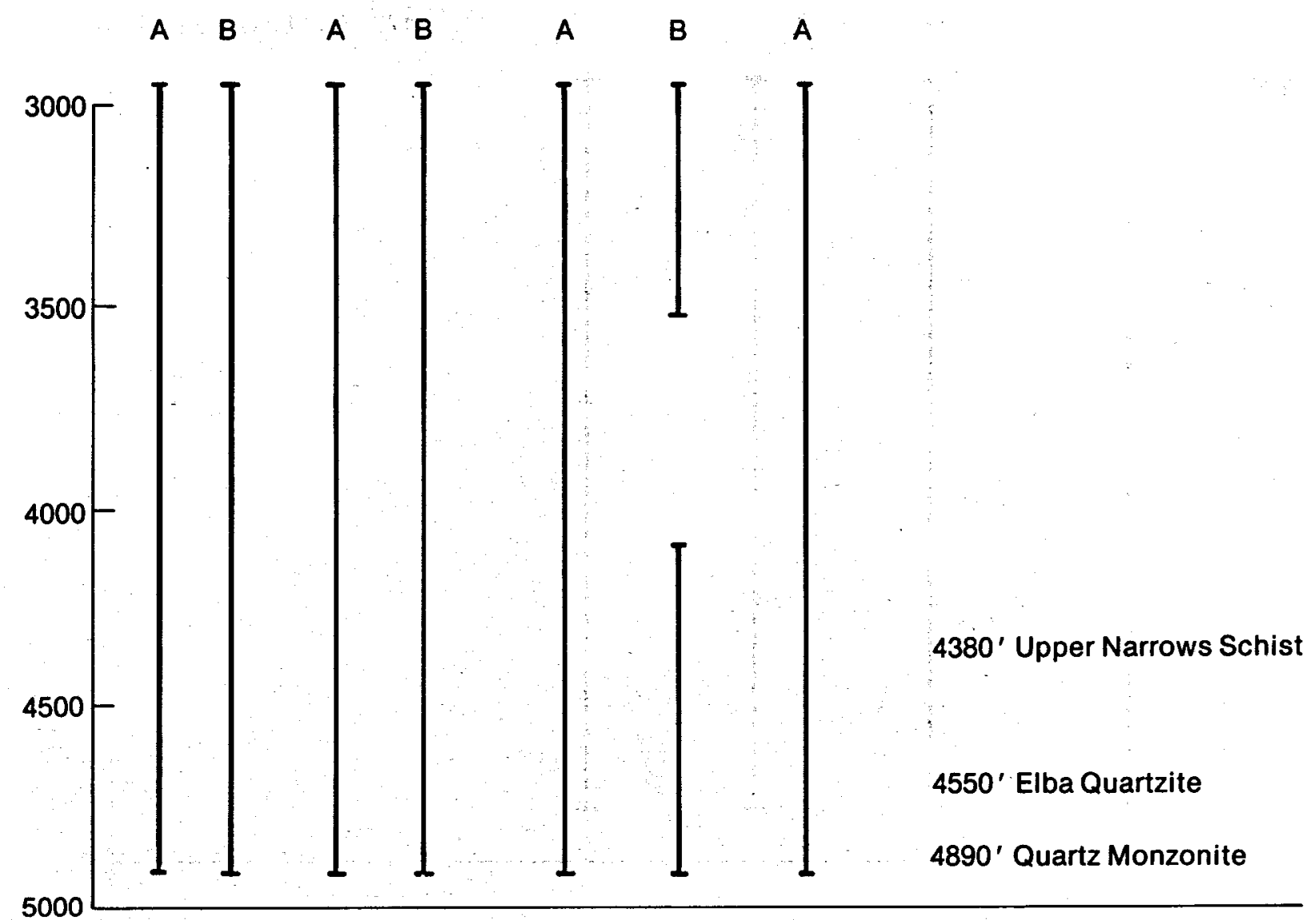

1) $S P$ is questionable from $4450^{\prime}$ to TD

2) SFL is questionable below $4650^{\prime}$

3) Density and neutron scales for wells $A$ and $B$ are not compatible, but the information is correct

4) The acoustic porosity curve on $\log A$ is not reading correctly; that is, the acoustic porosity on the $\log$, at a given $\Delta t$ and at a $51.3 \mu \mathrm{sec} / \mathrm{ft}$ matrix velocity, does not match the chart book porosity values

5) $\Delta t$ and density curve appear correct, but BGT caliper appears to be reading incorrectly

INEL-A-19 679

Figure 9. RRGP-5 log suite with notes on $\log$ quality. 


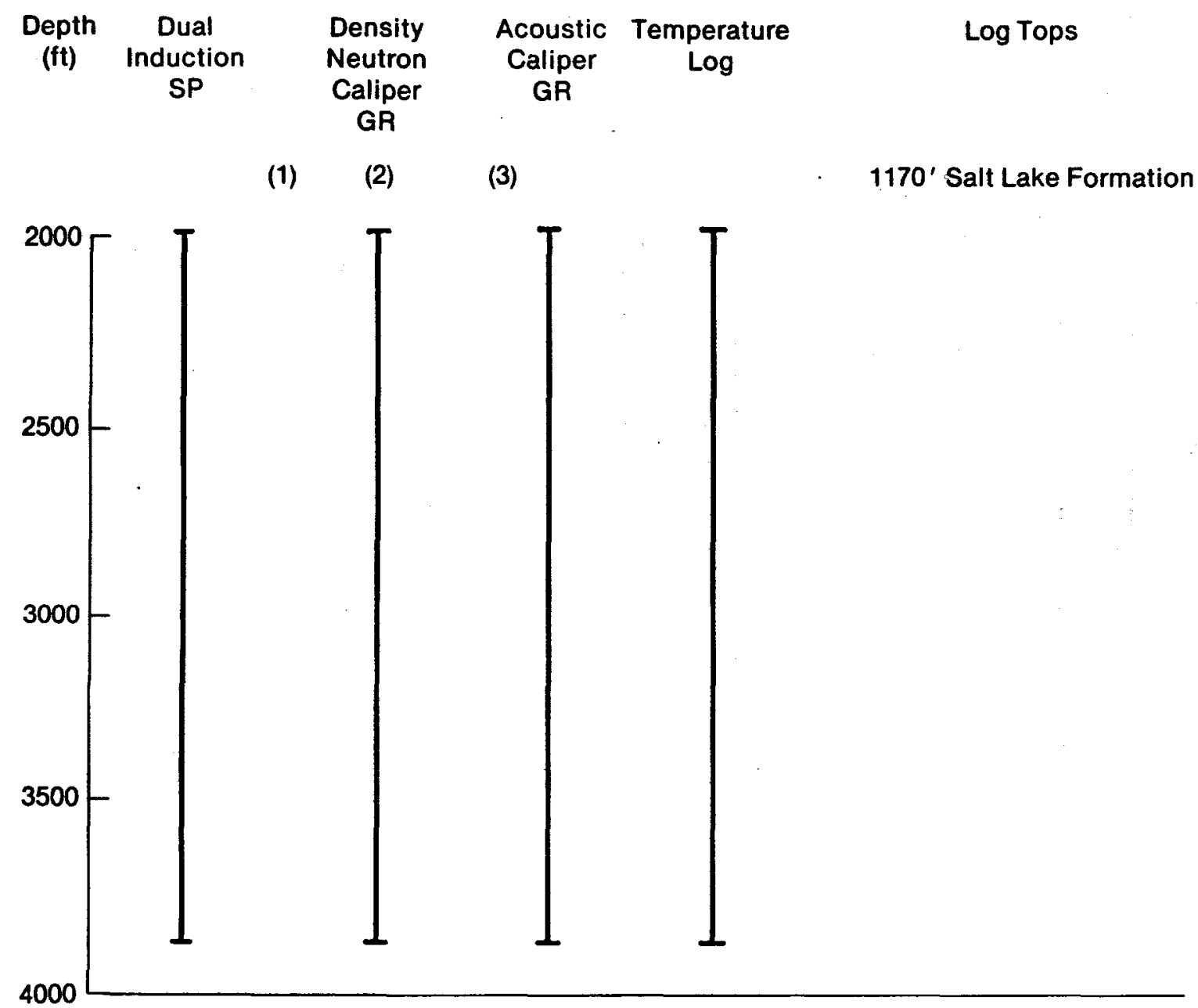

1) Borehole is washed out to 17 in. or greater

2) Backup porosity curves are not identified

3) No gamma ray on acoustic log; however, the log heading does indicate a gamma ray run on a scale of $0-150$

INEL-A-19 537

Figure 10. RRGI-6 log suite with notes on log quality. 


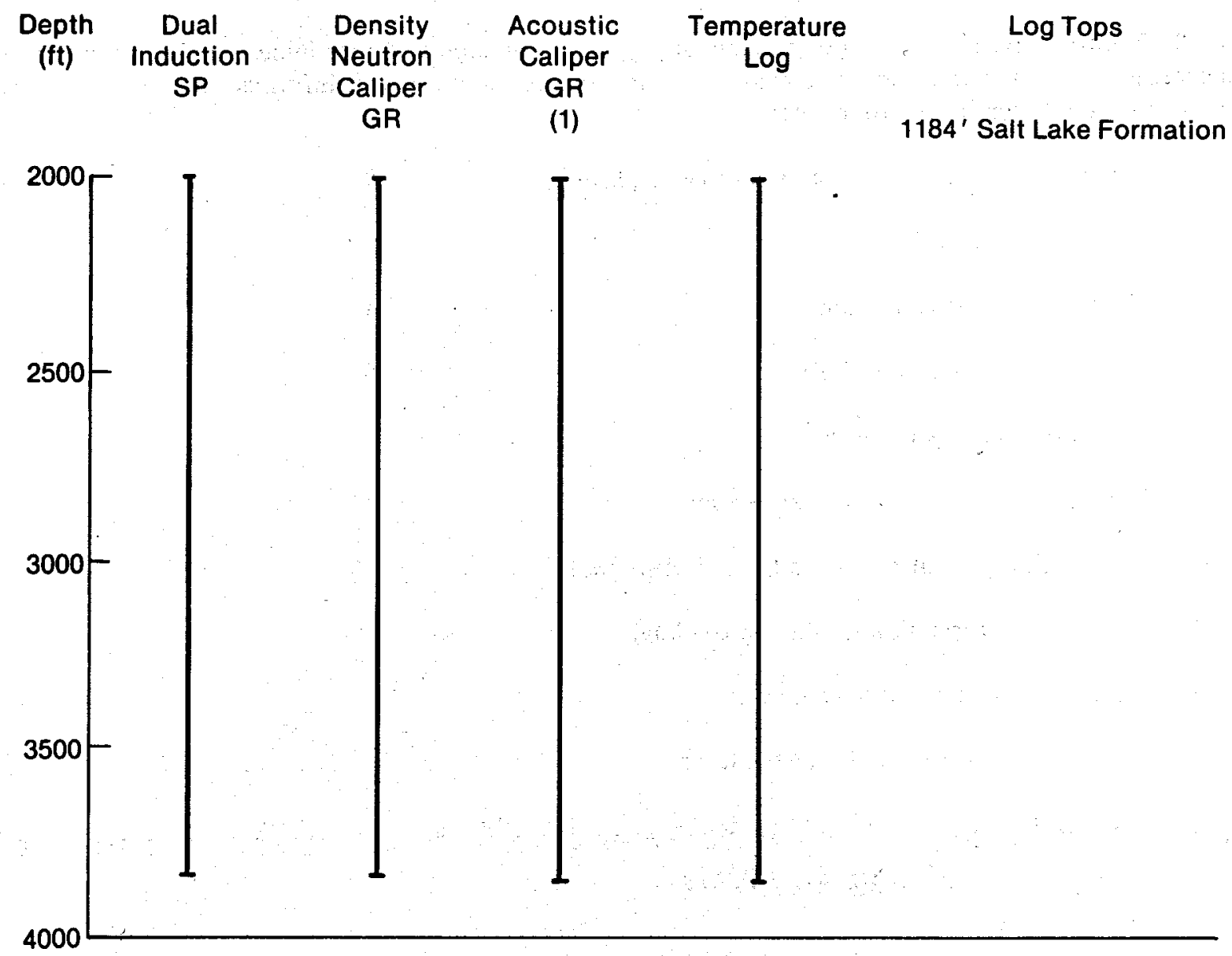

1) No caliper on acoustic log

Figure 11. RRGI-7 $\log$ suite with notes on $\log$ quality. 
It is critical that the tools be properly centralized and run with an operational caliper. Also the scales and reference points on the logs are inconsistent and often do not facilitate interpretation. It is also very important that log and drilling depths be referenced to the same point, either land surface or the kelly bushing. An important issue regarding utility of the log data in metamorphic and igneous rock types concerns coring. Core coverage and core recovery were typically less than $2 \%$ of the borehole. Core calibration of the logs is of paramount importance in an unknown basin geology.

3.3.3 Recommendations. In general, the logging programs should be determined in advance, and then a careful onsite inspection should be made to ensure complete and accurate information. A good logging program should identify the following:

1. The logs to be run and the curves to be displayed.

2. The logging intervals.

3. The proper scales to be run.

4: The updated tool calibrations.

5. The matrix settings to be run.

6. The repeat sections/intervals to be run.

7. The identification of all curves that are displayed.

8. The correct information on the log heading.

9. The acceptable depth discrepancy.

10. The acceptable repeatability of the tools.

\subsection{Classification of the Raft River Geothermal Reservoir from the Viewpoint of Log Analysis}

A possible classification scheme for the Raft River geothermal reservoir has been developed by S. K. Sanyal ${ }^{50}$ with the hope that the vast number of known geothermal reservoirs can be grouped into a small number of reservoir classes, each with its distinct set of log responses and typical log analysis problems. The distribution of geothermal reservoirs is outlined in Table 4. Consequently, the Raft River geothermal reservoir is classified ID, II A/C/D, III B, IV A/B, VA.

3.4:1 Identifying Reservoir Anomalies from Logs. The interpretation of geophysical logs has been refined extensively for petroleum applications. Unfortunately, in the Raft River production zones, lithology is not composed of sedimentary sequences; these metamorphic and igneous rocks are much more complex and have log responses that are almost totally unknown. For example, in the Raft River production wells, quartzite, tuff, quartz monzonite, schist, tuffaceous sandstone, shales, and siltstones are encountered. The log response from these materials is unique compared with the classical responses. Consequently, characteristic responses must be noted and an attempt made to understand the geological parameters causing these responses.

A first step was to identify anomalous zones. Some of the anomalous zones are outlined in Figures 12 through 17. The fracture zones shown by the acoustic televiewer are not shown because it is anticipated the USGS report will evaluate these fractures in depth. Tables 5 through 13 provide descriptions of anomalies in each well. 
Table 4. Distribution of geothermal reservoirs

\begin{tabular}{|c|c|c|c|}
\hline Parameter & Type & Description & $\begin{array}{c}\text { Frequency of } \\
\text { Occurrence } \\
(\%)\end{array}$ \\
\hline Fluid Type and Temperature & $\begin{array}{l}\text { IA } \\
\text { IB } \\
\text { IC } \\
\text { ID } \\
\text { IE }\end{array}$ & $\begin{array}{l}\text { Steam } \\
\text { High temperature water }(>400 \mathrm{~F}) \\
\text { Moderate temperature water }(300-400 \mathrm{~F}) \\
\text { Low temperature water }(<300 \mathrm{~F}) \\
\text { Dry }\end{array}$ & $\begin{array}{r}7.4 \\
33.3 \\
33.3 \\
22.3 \\
3.7\end{array}$ \\
\hline Lithologic Types & $\begin{array}{l}\text { IIA } \\
\text { IIB } \\
\text { IIC } \\
\text { IID } \\
\text { IIE } \\
\text { IIF }\end{array}$ & $\begin{array}{l}\text { Sedimentary } \\
\text { Metamorphic } \\
\text { Igneous (crystalline and glassy) } \\
\text { Volcanic ash and associated sediments } \\
\text { Breccia } \\
\text { Hydrothermally altered }\end{array}$ & $\begin{array}{r}22.2 \\
6.7 \\
31.1 \\
20.0 \\
-- \\
20.0\end{array}$ \\
\hline Geologic Province & $\begin{array}{l}\text { IIIA } \\
\text { IIIB } \\
\text { IIIC } \\
\text { IIID } \\
\text { IIIE } \\
\text { IIIF } \\
\text { IIIG }\end{array}$ & $\begin{array}{l}\text { Basin and Range } \\
\text { Northwest Volcanic } \\
\text { Salton Trough } \\
\text { Northern California Coast Range } \\
\text { Rio Grande Rift and Colorado Plateau Borderland } \\
\text { Hawaii } \\
\text { Alaska }\end{array}$ & $\begin{array}{l}38.5 \\
19.2 \\
23.0 \\
7.7 \\
7.7 \\
3.9 \\
--\end{array}$ \\
\hline Pore Geometry & $\begin{array}{l}\text { IVA } \\
\text { IVB } \\
\text { IVC }\end{array}$ & $\begin{array}{l}\text { Sedimentary intergranular } \\
\text { Fracture } \\
\text { Vesicular or vuggy }\end{array}$ & $\begin{array}{l}31.3 \\
50.0 \\
18.7\end{array}$ \\
\hline Salinity & $\begin{array}{l}\text { VA } \\
\text { VB } \\
\text { VC } \\
\text { VD } \\
\text { VE }\end{array}$ & $\begin{array}{l}\text { Low salinity }(<5000 \mathrm{ppm}) \\
\text { Moderate salinity }(5000-35000 \mathrm{ppm}) \\
\text { High salinity }(35000-100000 \mathrm{ppm}) \\
\text { Hypersaline }(>100000 \mathrm{ppm}) \\
\text { Dry }\end{array}$ & $\begin{array}{r}52.3 \\
30.4 \\
8.7 \\
4.4 \\
4.4\end{array}$ \\
\hline
\end{tabular}




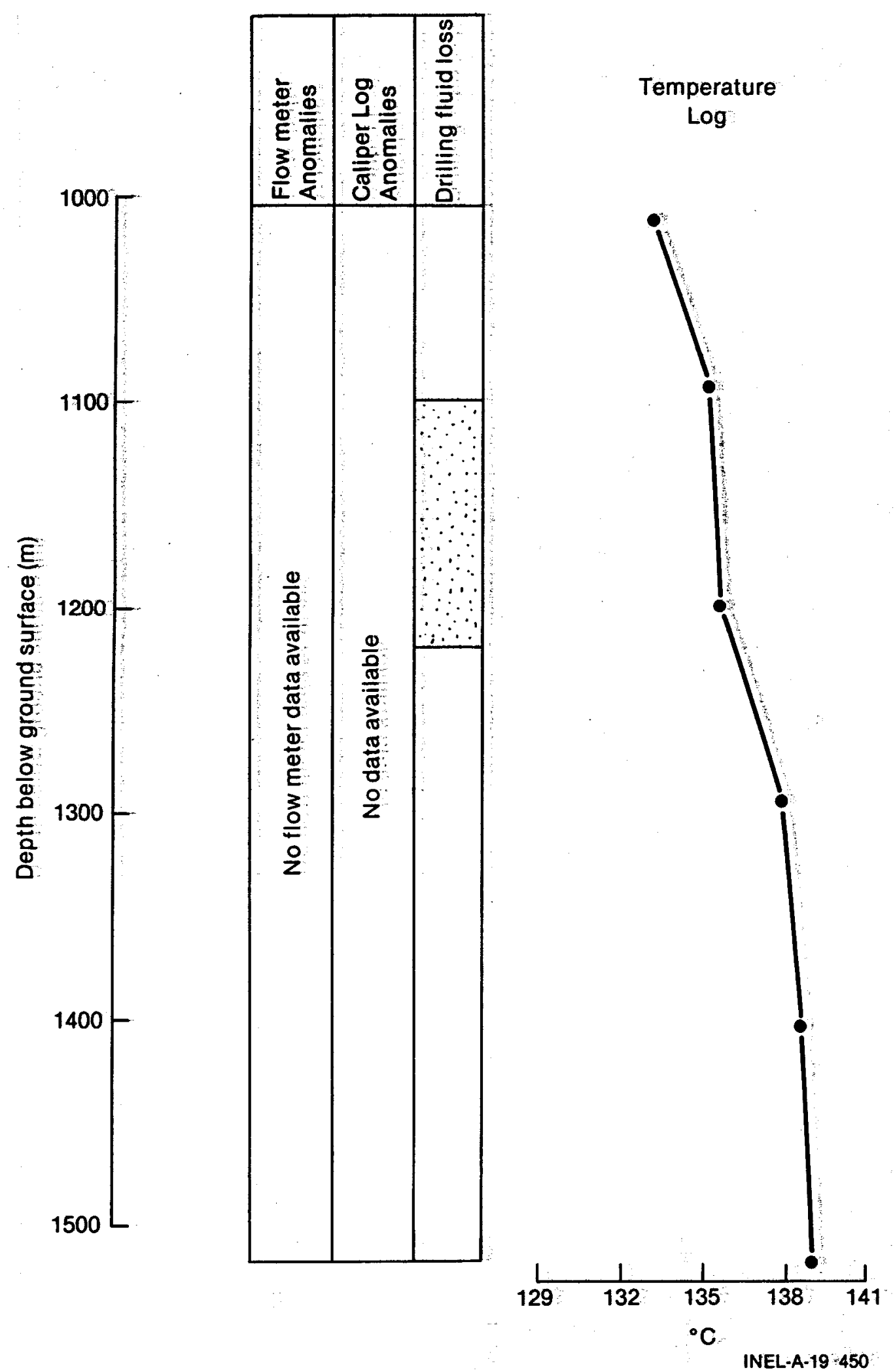

Figure 12. Anomalous zones from data on RRGE:1: 

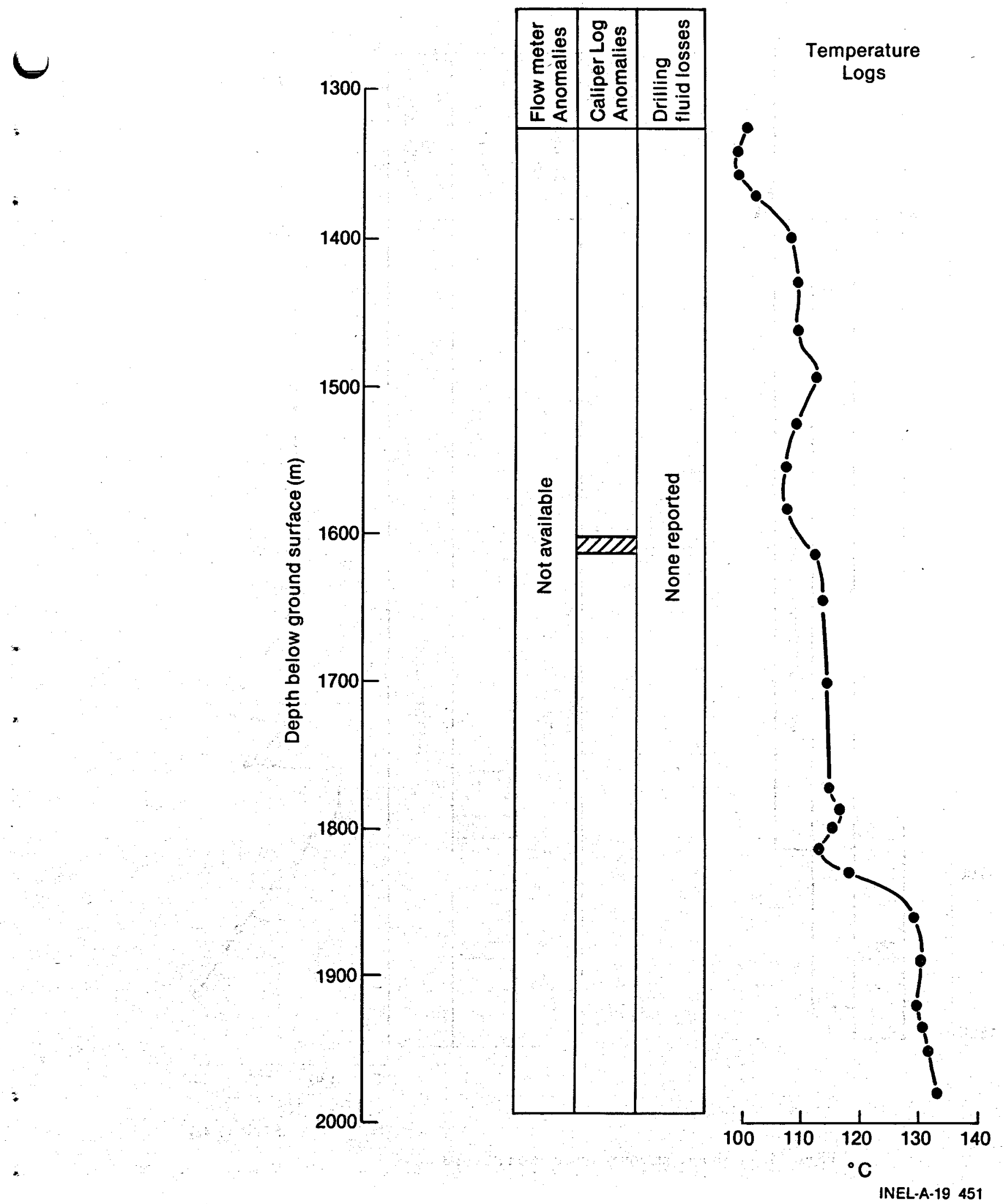

Figure 13. Anomalous zones from data on RRGE-2. 

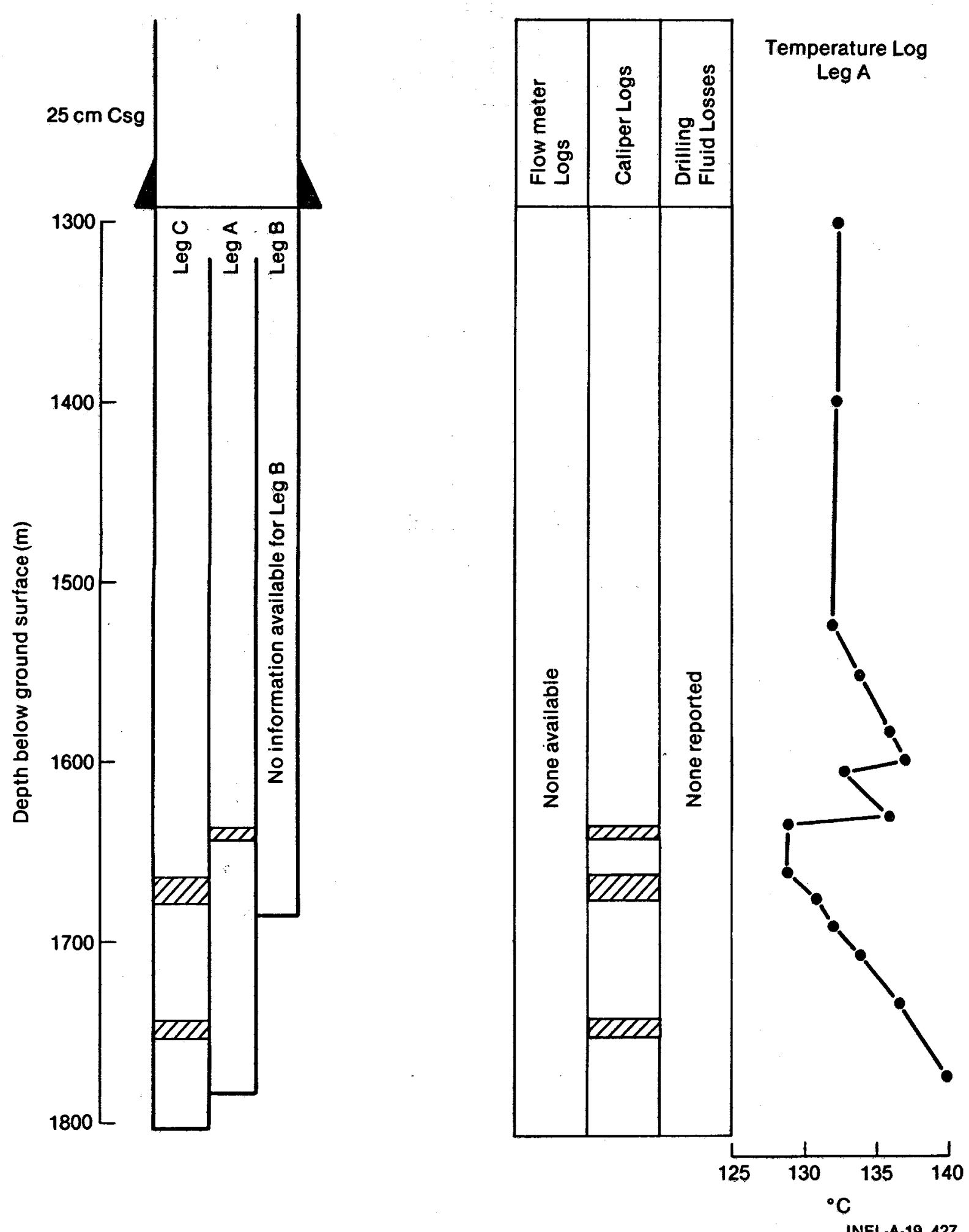

Figure 14. Anomalous zones from data on RRGE-3. 


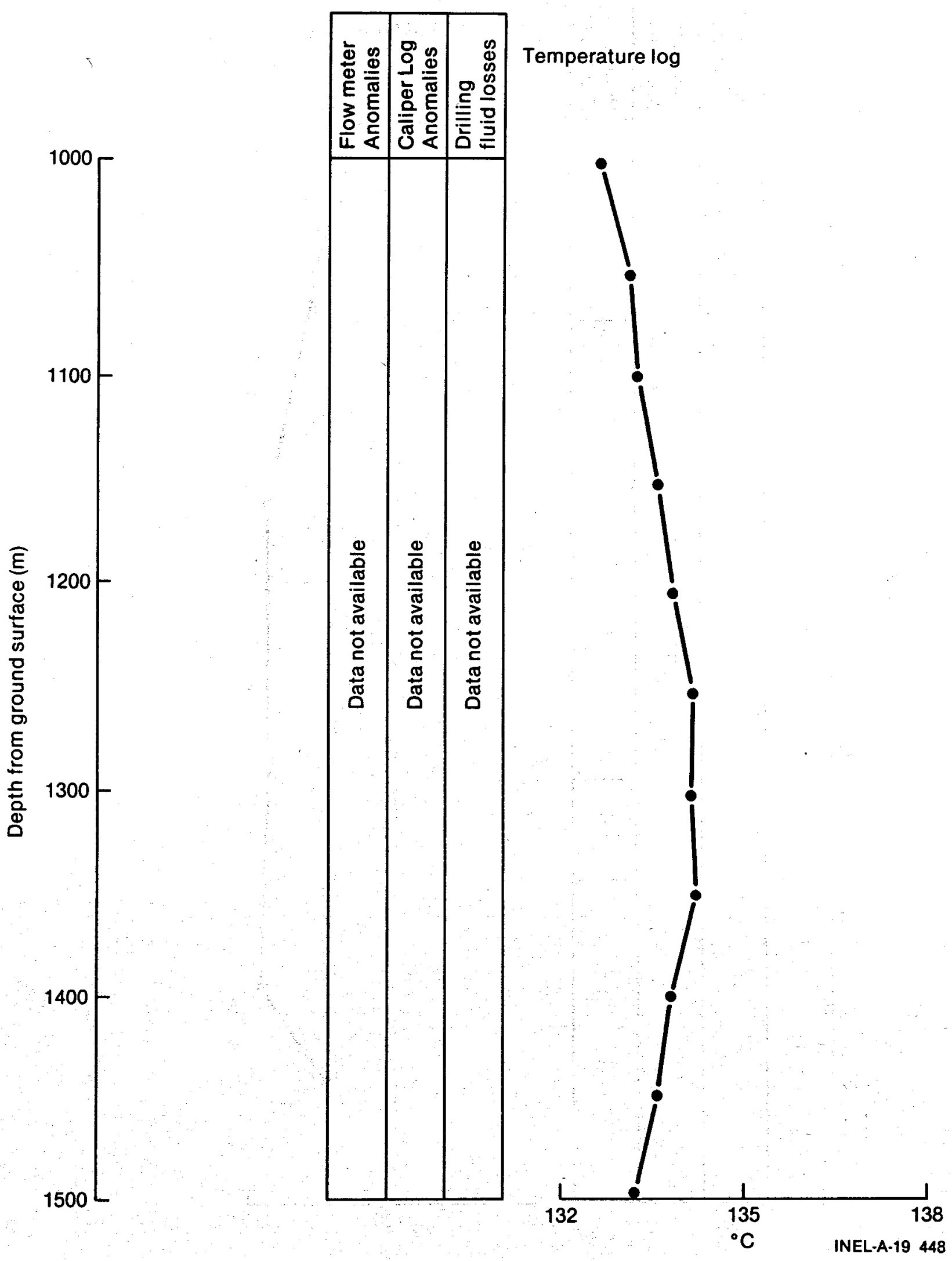

Figure 15. Anomalous zones from data on RRGP-5. 


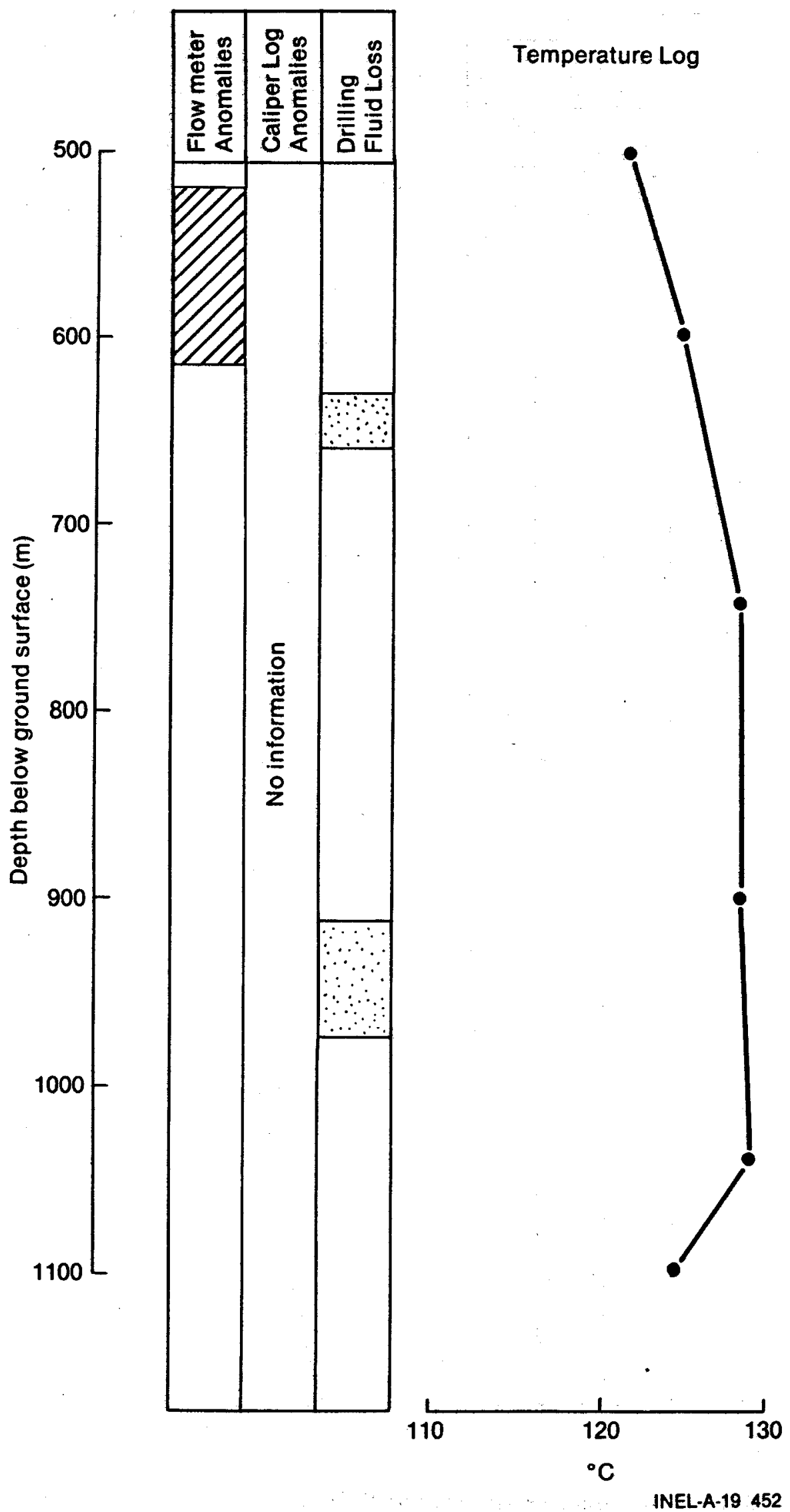

Figure 16. Anomalous zones from data on RRGI-6. 


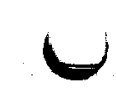

$+$

z

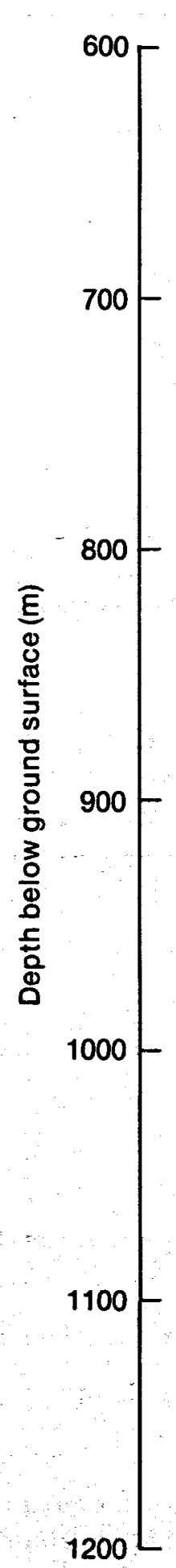

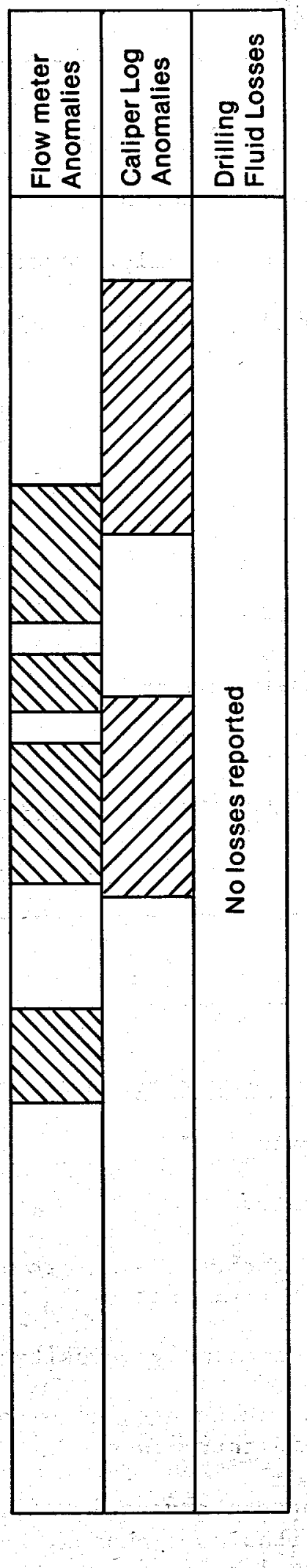
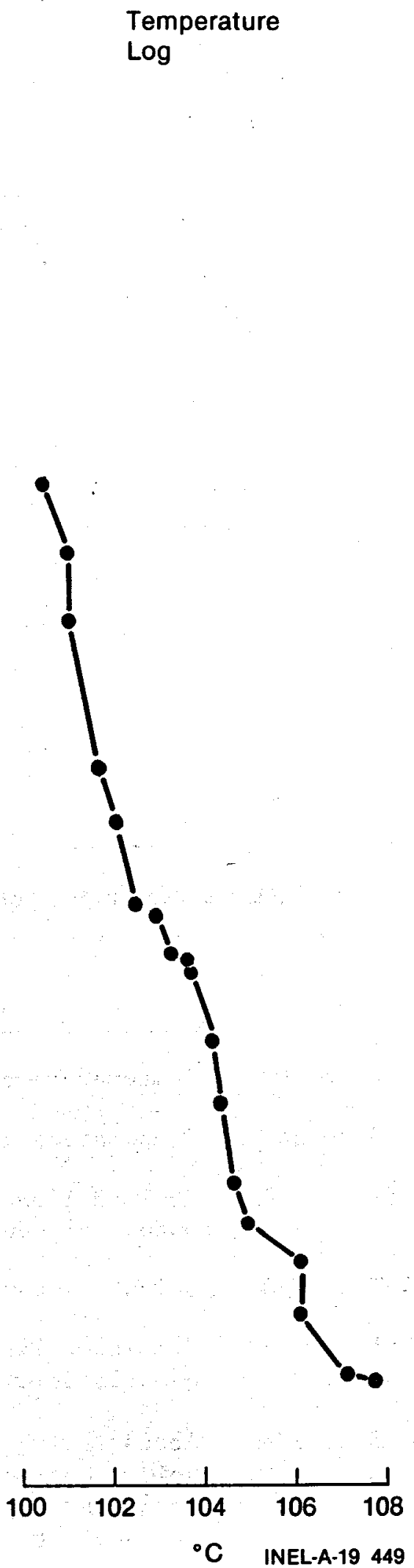

Figure 17. Anomalous zones from data on RRGI-7. 
Table 5. RRGE-1 anomalous zones

\begin{tabular}{c}
$\begin{array}{c}\text { Depth } \\
\text { (m) }\end{array}$ \\
\hline 1279 \\
1282 \\
1351 \\
1363 \\
1368 \\
1390 \\
1392 \\
1393 \\
1394 \\
1395 \\
1398 \\
1402 to 03 \\
1423 to 24 \\
\\
1424 to 43 \\
1451 to 53 \\
1453 to 59 \\
1473 \\
1478 to 96 \\
1489 to 96
\end{tabular}

Description of Anomaly

Prominent $\Delta t$ anomaly.

Obvious $\Delta t$ anomaly, possible fracture.

$\Delta t$ anomaly, correlates with ATV.

$\begin{array}{ll}" 1 & " 1 \\ " 1 & " 1 \\ " 1 & " 1 \\ " 1 & " 1 \\ " 1 & \end{array}$

$\Delta t$ anomaly, major vertical fracture system.

" "

$\Delta t$ anomaly, 12-degree bedding "plane.

1489 to 96

Table 6. RRGE-2 anomalous zones

\footnotetext{
Depth

(m)

Description of Anomaly

305 to 307 Temperature anomaly.

349 to 359 : Temperature anomaly.

358 to 373 Obvious lithologic change with prominent temperature break; potential zone of fluid entry, $\phi_{a}=0.21$.

467 to 468 Slight temperature anomaly opposite lost circulation zone.

705 to 767 Prominent lithologic change, high apparent porosity, but questionable fluid entry zone.

788 to 838 Acoustic log response adversely affected by irregular borehole; apparent lithologic change, but improbable zone of fluid entry--most likely siltstone interval with low permeability.

910 to 912 Temperature anomaly, questionable fluid entry.
} 
Table 6. (continued)

\begin{tabular}{|c|c|}
\hline $\begin{array}{l}\text { Depth } \\
(\mathrm{m})\end{array}$ & Description of Anomaly \\
\hline 937 to 938 & $\begin{array}{l}\text { Temperature breaks in fractured siltstone, questionable fluic } \\
\text { entry. }\end{array}$ \\
\hline 946 & $\begin{array}{l}\text { Abrupt, decided temperature break which correlates with a } \\
\text { zone of tight, }\left(\phi_{a}=0.15\right) \text { but probably higher permeabi- } \\
\text { lity rock than overtying intervals. }\end{array}$ \\
\hline 949 to 953 & Prominent temperature break; potential zone of fluid entry. \\
\hline 1039 to 1086 & Tight zone $\phi_{a}=0.18$ \\
\hline 1102 to 1158 & As above. \\
\hline 1250 to 1295 & $\begin{array}{l}\text { DST proven zone of fluid entry; logs indicate fluid entry } \\
\text { zone to be } 1254 \text { to } 1271 \mathrm{~m}, \phi_{a}=0.15\end{array}$ \\
\hline NOTE: No DIL & coverage over zones above. \\
\hline 1318 to 1322 & Increasing temperature gradient. \\
\hline 1322 to 1323 & $\begin{array}{l}\text { Probable zone of fluid entry in possible fractured zone; } \\
\text { prominent temperature anomaly. }\end{array}$ \\
\hline 1342 to 1357 & $\begin{array}{l}\text { Increasing temperature gradient throughout this interval } \\
\text { with probable fluid entry from } 1351 \text { to } 1353 \mathrm{~m} \text {. }\end{array}$ \\
\hline 1358 & $\begin{array}{l}\text { Anomalous temperature log response is most likely a mechani- } \\
\text { cal shift which was not labeled by the logging engineer. }\end{array}$ \\
\hline 1412 to 1417 & Logs detect a subtle temperature break. \\
\hline 1422 to 1445 & Probable zone of fluid entry in biotite schist. \\
\hline 1503 to 1505 & $\begin{array}{l}\text { Temperature anomaly in zone of potentially fractured rock, } \\
\text { probable fluid entry zone. }\end{array}$ \\
\hline 1507 to 1526 & $\begin{array}{l}\text { Anomalous zone as indicated by acoustic and resistivity logs; } \\
\text { probable zone of fluid entry, dense section, very possible } \\
\text { with low-angle fractures. }\end{array}$ \\
\hline 1591 to 1596 & $\begin{array}{l}\text { Temperature and resistivity anomalies in zone with irregular } \\
\text { borehole. }\end{array}$ \\
\hline 1750 & $\begin{array}{l}\text { Slight temperature anomaly which correlates with resistivity } \\
\text { depression in zone of lithologic change; possible fluid entry }\end{array}$ \\
\hline 1756 to 1764 & Zone of possible low-angle fractures. \\
\hline 1785 & slight temperature anomaly. \\
\hline
\end{tabular}


Table 7. RRGE-3A anomalous zones

\begin{tabular}{|c|c|}
\hline $\begin{array}{l}\text { Depth } \\
(\mathrm{m})\end{array}$ & Description of Anomaly \\
\hline 1311 to 1357 & $\begin{array}{l}\text { The temperature } \log \text { is the only diagnostic tool to predict } \\
\text { fluid entry; some of the acoustic log response may be indica- } \\
\text { tive of fractures. }\end{array}$ \\
\hline 1405 & Temperature break, no indications on other logs. \\
\hline 1570 & $\begin{array}{l}\text { Slight temperature change which correlates with lithologic } \\
\text { gradation into basement rock. }\end{array}$ \\
\hline 1602 to 1604 & Lithologic change associated with temperature decrease. \\
\hline 1636 to 1639 & As above. \\
\hline 1631 & $\begin{array}{l}\text { High apparent density porosities correlated with irregular } \\
\text { borehole conditions, acoustic response due to lithologic } \\
\text { changes. }\end{array}$ \\
\hline
\end{tabular}


Table 8. RRGE-3C anomalous zones

\begin{tabular}{|c|c|}
\hline $\begin{array}{l}\text { Depth } \\
(\mathrm{m})\end{array}$ & Description of Anomaly \\
\hline 1347 to 1351 & Minor hot zones, no other log indications. \\
\hline 1388 to 1406 & 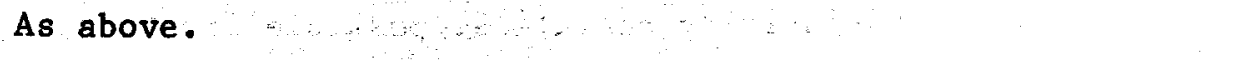 \\
\hline 1441 & Temperature change correlated with lithologic change. \\
\hline 1451 & $\begin{array}{l}\text { Minor temperature change correlated with neutron log } \\
\text { response. }\end{array}$ \\
\hline 1476 & $\begin{array}{l}\text { Minor temperature increase correlated with a substantial } \\
\text { increase in } \Delta t \text {. }\end{array}$ \\
\hline 1483 to 1485 & $\begin{array}{l}\text { Slight temperature increase, but in tight rock; no apparent } \\
\text { fracturing. }\end{array}$ \\
\hline 1527 to 1547 & $\begin{array}{l}\text { Minor temperature increases which correlate with resistivity } \\
\text { anomalies and very obvious } \Delta t \text { excursions. }\end{array}$ \\
\hline 1550 & $\begin{array}{l}\text { Cold zone at lithologic change, noticeably hotter below this } \\
\text { break to total depth (TD). }\end{array}$ \\
\hline 1599 & $\begin{array}{l}\text { Resistivity anomaly, possible transit time attentuation, } \\
\text { doubtful fluid production interval. }\end{array}$ \\
\hline 1669 to 1670 & $\begin{array}{l}\text { Potential hot zone as identified by FDC-CNL although no tem- } \\
\text { perature anomaly, possible lithologic change, no ATV } \\
\text { coverage. }\end{array}$ \\
\hline
\end{tabular}


Table 9. RRGP-4A anomalous zones

\begin{tabular}{|c|c|}
\hline $\begin{array}{l}\text { Depth } \\
(\mathrm{m})\end{array}$ & Description of Anomaly \\
\hline 1060.9 to 1070 & Minor temperature increase. \\
\hline 1078 to 1115 & Resistivity anomalies, possible fractures. \\
\hline 1173 to 1234 & As above. \\
\hline 1273 to 1297 & Temperature breaks at lithology changes. \\
\hline 1338 to 1349 & Temperature decrease. \\
\hline 1349 to 1375 & $\begin{array}{l}\text { Numerous resistivity anomalies, potential bedding and/or } \\
\text { fractures. }\end{array}$ \\
\hline 1392 to 1404 & $\begin{array}{l}\text { Prominent resistivity anomalies correlate with slight tem- } \\
\text { perature increase, potential fractures. }\end{array}$ \\
\hline 1418 to 1420 & Lithologic changes producing resistivity anomalies. \\
\hline 1422 to 1591 & $\begin{array}{l}\text { There are several temperature fluctuations which show no } \\
\text { correlation with other log responses or with lithologic } \\
\text { changes. }\end{array}$ \\
\hline 1591 to 1653 & Only temperature log coverage over this interval. \\
\hline
\end{tabular}


Table 10. RRGP-4B anomalous zones

\begin{tabular}{|c|c|}
\hline $\begin{array}{l}\text { Depth } \\
(\mathrm{m})\end{array}$ & Description of Anomaly \\
\hline 1070 & Slight temperature break. \\
\hline 1103 to 1114 & $\begin{array}{l}\text { Resistivity anomalies and acoustic attenuation most likely } \\
\text { due to the extremely large borehole. }\end{array}$ \\
\hline 1150 to 1154 & $\begin{array}{l}\text { Pronounced spinner response in very large hole, no other } \log \\
\text { anomalies. }\end{array}$ \\
\hline 1183 to 1197 & Pronounced spinner response; no other log anomalies. \\
\hline 1371 to 1418 & Cooling apparent as metamorphic contact approached. \\
\hline 1416 & $\begin{array}{l}\text { Metamorphic log top contact, correlates with temperature } \\
\text { break and attenuated acoustic response, possibly indicative } \\
\text { of fractures. }\end{array}$ \\
\hline 1444 to 1449 & Slight temperature break, no other $\log$ correlation. \\
\hline 1478 to 1494 & $\begin{array}{l}\text { Temperature peak at } 1492 \text { m opposite subtle resistivity anom- } \\
\text { aly, a few other resistivity departures, and slight transit } \\
\text { time attenuation in this interval--possible zone of fluid } \\
\text { entry. }\end{array}$ \\
\hline 1501 to 1510 & Probable zone of low-angle fractures. \\
\hline 1528 & Temperature peak correlates with acoustic anomaly. \\
\hline 1546 to 1553 & $\begin{array}{l}\text { Possible low-angle fractures as evidenced by acoustic and } \\
\text { resistivity response. }\end{array}$ \\
\hline \multicolumn{2}{|c|}{ Correlation of Conventional Acoustic Anomalies ${ }^{a}$ with GR-Spectralog } \\
\hline & Acoustic Anomaly \\
\hline & 1777 to 1778 \\
\hline & 1771 to 1772 \\
\hline & $\begin{array}{l}1366 \text { to } 1376 \\
1502 \text { to } 1503\end{array}$ \\
\hline & 1543 to 1543 \\
\hline $\begin{array}{l}\text { a. Acoustic } \\
\text { GR-Spectralo }\end{array}$ & ths, acoustic recorded 0.3 to $0.6 \mathrm{~m}$ lower than \\
\hline
\end{tabular}


Table 11. RRGP-5A anomalous zones

\begin{tabular}{|c|c|}
\hline $\begin{array}{l}\text { Depth } \\
\text { (m) }\end{array}$ & Description of Anomaly \\
\hline 1149 to 1169 & $\begin{array}{l}\text { Lithology potentially fractured, faulted, and bedded; resis- } \\
\text { tivity and acoustic log responses correlate with core } \\
\text { descriptions from overlying rock. }\end{array}$ \\
\hline 1205 to 1287 & Log responses of questionable value due to oversize hole. \\
\hline 1335 to 1355 & $\begin{array}{l}\text { Prominent resistivity anomalies, potential zone of } \\
\text { production. }\end{array}$ \\
\hline 1384 & $\begin{array}{l}\text { Decided temperature reduction below this level which corre- } \\
\text { lates with lithologic change into quartzites. }\end{array}$ \\
\hline 1465 to TD & Numerous acoustic anomalies, possible fluid entry. \\
\hline
\end{tabular}

Table 12. RRGP-5B anomalous zones

\begin{tabular}{|c|c|}
\hline $\begin{array}{l}\text { Depth } \\
(\mathrm{m})\end{array}$ & Description of Anomaly \\
\hline 1358 & $\begin{array}{l}\text { Prominent temperature break occurs at this point, higher than } \\
\text { in Leg } A \text {. } \\
\text { Interval not logged with acoustic tool. }\end{array}$ \\
\hline $\begin{array}{l}\text { Depth } \\
(\mathrm{m})\end{array}$ & Description of Anomaly \\
\hline 747 to 760 & $\begin{array}{l}\phi=0.20 \text {, questionable fractures, no significant televiewer } \\
\text { anomalies. }\end{array}$ \\
\hline 823 to 832 & $\begin{array}{l}\phi=0.19 \text { to } 0.23 \text {, variable rock quality; doubtful if } \\
\text { fractured. }\end{array}$ \\
\hline 1045 to 1052 & $\begin{array}{l}\text { Doubtful fractures, apparent lithologic change, hole is } \\
\text { enlarged, log responses of questionable validity. }\end{array}$ \\
\hline 1089 to 1102 & $\begin{array}{l}\$=0.15 \text { to } 0.18 \text {, hot zone, no fracture indications, poten- } \\
\text { tial fluid entry zone. }\end{array}$ \\
\hline 1131 to 1142 & $\begin{array}{l}\phi=0.18 \text { to } 0.27 \text {, temperature break, probable fluid entry } \\
\text { zone. }\end{array}$ \\
\hline
\end{tabular}


3.4.1.1 RRGE-1-An attempt was made to correlate the acoustic televiewer (ATV) response to conventional tools. Meter-by-meter correlations between the standard acoustic tool and the ATV were not possible. In fact, some of the strongest ATV fracture indications were missed entirely on the acoustic log and vice versa. Based on what correlation did exist between the two, the fractured zones occurred at an interval below $1219 \mathrm{~m}$.

3.4.1.2 RRGE-2-Commercial log coverage terminates at $1831 \mathrm{~m}$ in RRGE-2. Below this depth the USGS ran temperature logs, flow meters, and the acoustic televiewer tool. Keyes 48 should be consulted for interpretation of these surveys. This well was also discussed by Sanyal, 50 in which a good summary of crossplotting techniques was presented with RRGE-2 as an example.

All logs proved useful for interpretation of this well. The acoustic log exhibits responses that are indicative of low-angle fractures at depth. The acoustic televiewer log isolates numerous, major high-angle fractures in a network below $1829 \mathrm{~m}$.

3.4.1.3 RRGE-3-There are a number of hot zones at shallow depths of well 3. This well has three legs as shown in Appendix B, Figure B-8. Average apparent porosities are about 0.15 to 0.18 , so it is somewhat questionable that these zones would yield fluid. No core was obtained at shallow depths. The available core suggests that the sharp attenuations in acoustic response may be correlated with bedding planes or lowangle fractures. Where high-angle fractures are present, the acoustic log does not identify them.

Temperature changes below $1220 \mathrm{~m}$ correlated with major lithologic changes. The absolute values of temperature cannot be trusted on well 3 , Leg $\mathrm{A}$ - the temperature readings changed as scale changes were made. Well 3, Leg B was difficult to reenter and had no diagnostic logs run.

There is a substantial amount of anomalous acoustic response in both Legs A and C. The ATV anomalies are present in Leg $C$, and no correlation could be established between these and conventional $\log$ responses.

3.4.1.4 RRGP-4-Primarily due to poor log quality, zones of fluid entry were impossible to delineate in well 4 Leg A. The dual-induction focused log (DIFL) was the only good quality log. Based on the DIFL, potential fracture zones are apparent from $1077 \mathrm{~m}$ to the metamorphic rocks, indicating a probable hydraulic connection.

Log quality improved substantially on well 4, Leg B; the only problem was failure of the spinner flow meter due to high borehole temperature.

The acoustic televiewer logs showed little correlation with conventional log response. Well 4, Leg B is similar to well 3 in that few prominent fractures were visible.

3.4. 1.5 RRGP-5A-A temperature decrease occurred in both Legs A and B near the lithologic change from the metamorphics into the igneous basement. This is similar to the change that occurred in well 4, Leg B at the Precambrian. This temperature decrease was not experienced in wells 1,2 , or 3 .

Fluid production zones were difficult to delineate in well 5 . Based on the spinner and temperature surveys, the dense schist at 1357 to $1387 \mathrm{~m}$ in well 5, Leg A was an apparent production interval. The quartzite zone from 1335 to $1354 \mathrm{~m}$ was also a contributor, corroborated by resistivity logs.

The acoustic televiewer indicates promise for well 5, Leg B, including the deep zones. Numerous acoustic anomalies are present from $1433 \mathrm{~m}$ to TD which correlate with ATV fracture response. The resistivity log shows poor correlation in the deep zones, but some resistivity response from 1250 to $1357 \mathrm{~m}$ does correlate with ATV zones of interest.

3.4.1.6 RRGI-6-As a result of the large hole, the logs on this well are essentially useless for quantitative interpretation. A cursory examination revealed no significant zones of interest. 
3.4.1.7 RRG1-7-This well is rather nondescript, but once again the hole is so large over most of the well that it renders wireline log responses nearly useless. The televiewer logs showed low-angle contacts, bedding features, and lithologic changes. A few fractures of varying angles were noted below $762 \mathrm{~m}$. None of these correlate with conventional logs. The intervals of interest are few in number due to low confidence in the log data.

3.4.2 Crossplot Interpretation. The Raft River geothermal reservoir is primarily tuffaceous siltstone, conglomerate, and sandstone in the upper section. Below this sequence, a metamorphic zone of phyllite, schist, and quartzite rests on the quartz monzonite basement rock. The fluid production from the Raft River is dependent on highly fractured zones. 49

From the logging standpoint, the reservoir lithology poses several problems. Standard calibrations are inadequate, matrix responses of the mineral constituents are unknown, and mineral composition varies drastically from zone to zone. Consequently, the conventional complex lithology analysis, aided by crossplots, provides the best interpretation model for the igneous and metamorphic-type lithologies. This technique may at first appear to be an oversimplification of a complex problem, but it is the key to model development for further computations. To determine permeability, porosity must be known, and in order to determine porosity, lithology must be known in order to specify the matrix response of the logging tools being used. The crossplot techniques, then, hold the key to determining several formation parameters that are important to the Geothermal industry.

A $530 \mathrm{~m}$ interval from the RRGE-2 well was selected for study of lithology definition. Porosity and M-N crossplots were made, as shown in Figure 18 and applied to the following two rock groups.

3.4.2.1 Group 1: Quartz Monzonite and Quartzite-The porosity data plots primarily between the classical matrix lines for standstone and limestone. Distinction between the two can be made by two characteristics. The quartz monzonite (1524 $\mathrm{m}$ ) is predominantly less dense than the quartzite. The neutron log, however, shows both types of rocks to have very little porosity or associated water or hydrogen. Another distinctive characteristic is the gamma ray response. The quartz monzonite is very radioactive as compared to the quartzite, and on the log, the gamma ray is saturated over the quartz monzonite interval. Likewise, the resistivity is saturated and the neutron porosity is essentially zero. (See Figures 18 and 4.)

3.4.2.2 Group 2: Schist-The zone between 1734 to $1756 \mathrm{~m}$ is shown on the cross plots as having the highest density and the highest neutron hydrogen index in the studied interval. The transit time is about $164 \mu \mathrm{s} / \mathrm{m}$. This zone plots far outside the "standard"' lithology lines as shown in Figure 18, and is readily correlated.

Figure 4 identifies quartzite, quartz monzonite, and the schist zones on the M-N plots.

3.4.3 Lithologic Indications from Logs. Using RRGE-2 as an example, Table 14 was constructed outlining $\log$ anomalies of the zones that were identified in the crossplot interpretation section. As indicated in Table 14, the lithologic zones cause drastic changes in some log responses. As an example, the schist exhibits high resistance, high density and low gamma, whereas the quartz monzonite exhibits high resistance, low density, low neutron porosity, and high gamma.

\subsection{Conclusions}

Because of the scope and nature of this report, a full log interpretation of all wells at the Raft River was not attempted. One of the main reasons was that some wells did not have the logs digitized, and under the conditions found at Raft River, computer digitization of the data is necessary. Another problem with doing an extensive $\log$ analysis is that the wells were drilled with water. This drilling technique was necessary; however, the drilling with water caused large borehole washouts and consequently poor log quality. Also, many qualitative interpretive techniques depend on drilling mud and its invasion and mud cake buildup capabilities. 51 Therefore, interpreting logs in water-drilled holes was very difficult. 
Finally, even though the igneous and metamorphic zones were easily distinguishable from the crossplots, the effects of hydrothermal alteration prevented the determination of porosity values and production zones. Therefore, a more extensive study must be made. This extensive study should include the statistical variation and filtering techniques using the raw logging data. The effects of hydrothermal alteration could then be considered, and more accurate matrix parameters in igneous and metamorphic environments could be obtained.

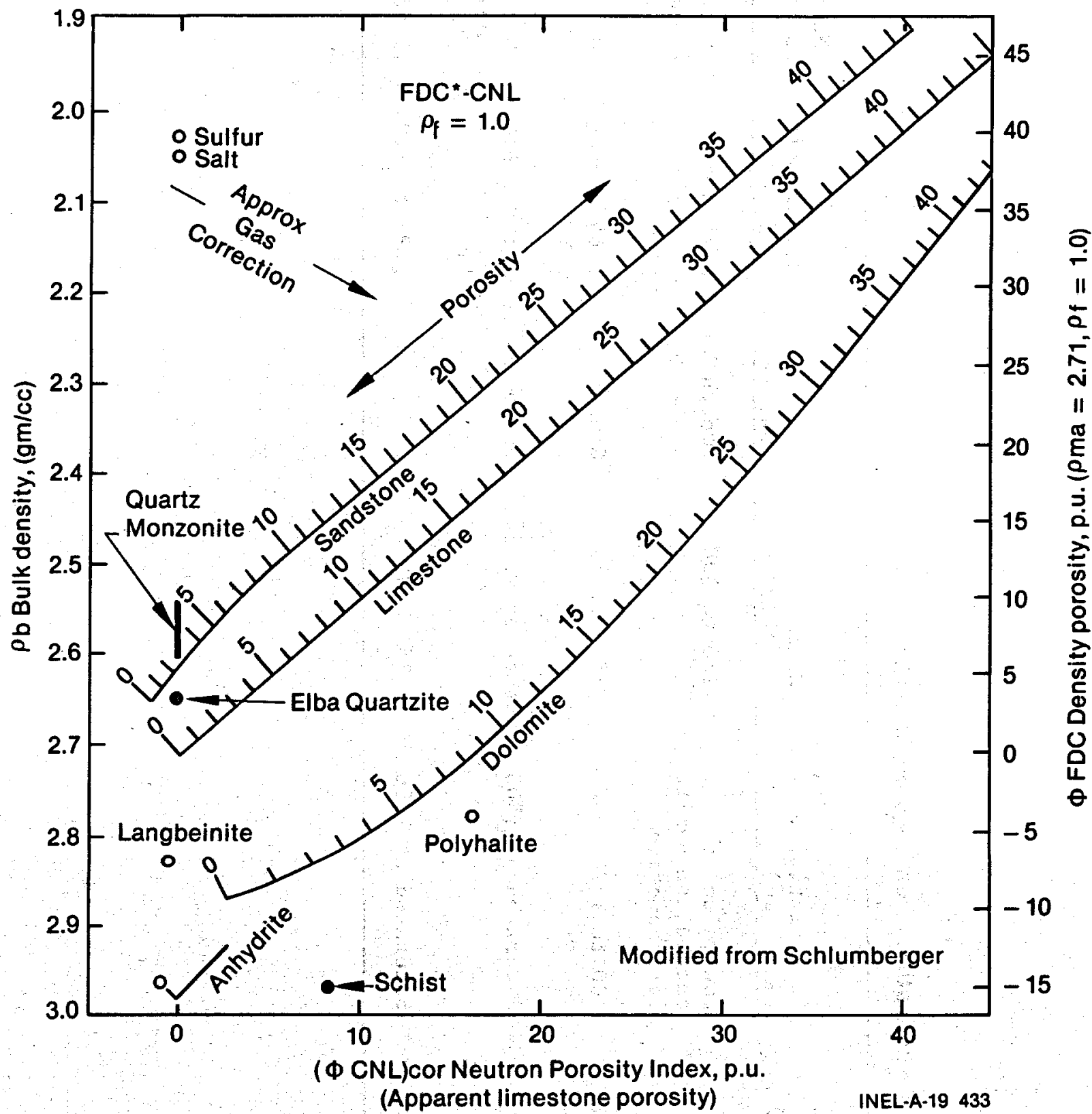

Figure 18. Bulk density-porosity plot from Schlumberger modified to show Raft River rock types. 
Table 14. Lithologic indications from logs on RRGE-2

\begin{tabular}{|c|c|c|c|c|c|c|}
\hline & $\begin{array}{c}\text { Resistivity } \\
(\mu \mathrm{m})\end{array}$ & $\begin{array}{c}\text { Gamma Ray } \\
\text { (APIV) }\end{array}$ & Caliper & $\begin{array}{l}\text { Bulk Density } \\
(\mathrm{g} / \mathrm{cc})\end{array}$ & $\begin{array}{c}\text { Neutron } \\
\text { Porosity } \\
(\%) \\
\end{array}$ & $\begin{array}{c}\text { Acoustic } \\
\Delta t \\
(\mu s / f t) \\
\end{array}$ \\
\hline $\begin{array}{l}\text { Narrows Schist } \\
\text { transition zone } \\
1422-49\end{array}$ & $\begin{array}{l}\text { Low value to } \\
\text { saturation pyrite } \\
\text { is conductive }\end{array}$ & 125 to 250 & $\begin{array}{l}\text { Smooth but } \\
\text { enlarged }\end{array}$ & 2.75 average & $7^{5}$ to 12 & 60 \\
\hline $\begin{array}{l}\text { Elba Quartzite } \\
1449-1520\end{array}$ & 200 to 1500 & 75 average & Gauge & 2.65 average & $\begin{array}{l}0 \text { to } 1 \\
5 \text { maximum }\end{array}$ & 55 \\
\hline $\begin{array}{l}\text { Quartz Monzonite } \\
1520-1734 \text { and } \\
1756-\text { TD }\end{array}$ & Saturated at 1500 & Saturated at 340 & Gauge & 2.55 to 2.60 & $\begin{array}{c}0 \text { to } 1 \\
5 \text { maximum }\end{array}$ & 52 \\
\hline Schist $1734-1756$ & Saturated at 1500 & 25 to 30 & & 2.95 to 3.0 & 12 to 13 & 50 \\
\hline
\end{tabular}




\section{HYDROLOGY OF THE RAFT RIVER GEOTHERMAL SITE}

\subsection{Introduction}

Drilling of Raft River geothermal production wells, injection wells, and monitor wells has been conducted since 1975. Although numerous tests were run during the development of the well fields, other activities precluded obtaining reservoir data as the primary goal. Late in the program, difficulties were encountered with downhole pumps, further accentuating the difficulties in long-term reservoir drilling.

Ground water, petroleum, and high-temperature geothermal equipment and techniques were used to test the Raft River wells. Numerous tests, less than 8 hours in duration, are of questionable value due to timedependent thermal effects of the wellhead data and/or discharge rate control problems. The evaluation which follows is based on previously analyzed well tests that were longer than $\mathbf{8}$ hours in duration.

\subsection{Previous Reports}

Reports that have been published on reservoir testing and evaluation at the Raft River Geothermal Site, include an evaluation of the shallow aquifer system, 52,53 an evaluation of the deep geothermal system, $54,55,56,57,49$ and an evaluation of the "intermediate zone." 8,58,59 Numerous technical memorandums and internal reports have been issued, but are unavailable. The data and a synopsis of each test analysis will be presented in this section.

\subsection{Well Field Development}

The Raft River geothermal field includes five deep geothermal exploratory production wells and two intermediate depth injection wells. Drilling of these wells was completed between 1975 and 1978.

The site for the Raft River geothermal exploration No. 1 (RRGE-1) was one of several considered after extensive surveys were conducted by the Idaho National Engineering Laboratory (INEL) and the United States Geological Survey (USGS) in the late fall of 1974. The RRGE-1 well was designed to initially confirm the existence of hot water in quantities potentially suitable for commercial power applications. Drilling operations were started early in January 1975 and were completed at a total depth of about $1521 \mathrm{~m}$ on April 1, 1975. For RRGE-1 construction details, see Appendix B, Figure B-2. Limited flow testing and reinjection testing were performed before demobilizing the drill rig. A flow rate of approximately $37.8 \mathrm{~L} / \mathrm{s}$ was measured and a maximum downhole temperature of $144^{\circ} \mathrm{C}$ was recorded. 4

The site for the Raft River geothermal exploration No. 2 (RRGE-2) was selected by the Idaho National Engineering Laboratory (INEL). The RRGE-2 well was designed to intersect a deep geothermal circulation system and possibly confirm the existence of hot water in quantities potentially suited for commercial power applications. Drilling operations were started in late April 1975 and were suspended at a depth of about $1825 \mathrm{~m}$ on June 26, 1975. Limited flow testing, logging, and reinjection testing were performed. Limited flow testing up to $50.4 \mathrm{~L} / \mathrm{s}$ discharge, resulted in a maximum downhole temperature of $147^{\circ} \mathrm{C}$. Drilling operations were reactivated in early March 1976 and the well was drilled an additional $169 \mathrm{~m}$ to a total drilled depth of $1994.0 \mathrm{~m}$ from ground level. For RRGE-2 construction details, see Appendix B, Figure B-5. Coring, logging, and flow testing were accomplished during drilling and after completion of the well. 5

The Raft River geothermal exploration No. 3 (RRGE-3) was designed as a possible reinjection well. A unique feature of this well was that it consisted of three directional legs originating from a single wellbore. For RRGE-3 construction details, see Appendix B, Figure B-8. Drilling operations commenced on March 28, 1976, after the drill rig was relocated from the RRGE-2 site. The last of the three directional legs of the well reached total depth on May 24, 1976.6 
The drilling and completion of RRGE-1, -2, and -3 was performed by Reynolds Electrical and Engineering Co., Inc. (REECo), under the direction of the United States Energy Research \& Development Administration (ERDA), Nevada Operations Office (NV). Technical program requirements were provided by the INEL. The Manager of ERDA, Idaho Operations Office (ID), was responsible for the coordination of all project related activities between NV/REECo and ID/INEL and for funding the drilling operation.

The Raft River geothermal injection No. 4 (RRGI-4) well was originally designed and drilled as an injection well. The first stage of drilling began April 8, 1977 and was completed on May 4, 1977 to a depth of $866 \mathrm{~m}$ below ground level (GL). The deepening of RRGI-4 well (now to be called RRGP-4) to the actual depth began on September 21, 1978, and was completed on November 15, 1978. Two legs were drilled to depths of $1652 \mathrm{~m} \mathrm{GL}$ and $1558 \mathrm{~m}$ GL. For RRGP-4 construction details, see Appendix B, Figure B-11. The RRGP 4 well is a poor producer and is used for reservoir monitoring rather than production. 60,10

The Raft River geothermal production No. 5 (RRGP-5) well was designed to be completed as a production well with three barefoot legs. For RRGP-5 construction details, see Appendix B, Figure B-14. Because of technical and funding problems, two legs were drilled; only one leg is producing geothermal fluid. Drilling operations began on May 7,1978, and were completed on September 14. (Drilling was interrupted to drill another well during July and August 1978). The producing leg of RRGP-5 well is $1497 \mathrm{~m}$ deep. 61 Colorado Well Service performed the drilling and completion of RRGP-4 and RRGP-5. The drilling supervision, subcontracted by EG\&G, was conducted by an independent company-Energy Drilling Specialists of Denver, Colorado. Technical direction was supplied to the drilling subcontractor through the drilling supervisor. DOE-ID provided funding for the drilling operation and EG\&G provided procurement services.

Raft River geothermal injection Nos. 6 and 7 (RRGI-6 and RRGI-7) were designed for injection into the intermediate depth zone. This 600 - 1000-m zone was selected in order to minimize contamination of near surface ground water, to prevent the cooling of deep geothermal reservoir, and to reduce well cost. RRGI-6 well was drilled in April 1978 and RRGI-7 was drilled in July 1978, both to the total depth of $1172 \mathrm{~m} .9,62$ Injection wells were drilled by Colorado Well Service under supervision of Energy Drilling Specialists of Denver, and direction of EG\&G Idaho, Inc., and DOE-ID. (For RRGI-6 and -7 construction details, see Appendix B, Figures B-17 and B-18.) All of the exploratory and production wells penetrate total thickness of the basin sediments and are terminated in quartz monzonite basement. The injection wells are terminated in, and open to, fractured and porous Salt Lake Formation sediments.

\subsection{Methods of Well Testing}

Limited well testing was conducted during drilling of the exploration, production, and injection wells. Additional tests were conducted immediately after completion of each well. The objectives of many of the tests were to evaluate pumps, or the 5MW power plant facilities. The secondary objective of such a test was to obtain well performance data, reservoir parameters, or to monitor effects on shallow aquifers. Only a few tests were run with the primary objective of understanding the resource and the reservoir. Many of the test methodologies were dependent on the primary objectives and the immediate availability of pumps and instrumentation.

4.4.1 Well Tests During Drilling. Short artesian flow tests were conducted either after drilling activity reached a casing depth, a loss circulation zone, or total depth. The flow control for most of these tests was nonexistent. Occasionally, manually operated gate valves were used for regulating the discharge rate. Only flowing wellhead pressure and temperature data were taken during the production portion of the tests. During recovery, data were collected with a wellhead pressure gauge. Temperature measurements were taken on an irregular basis with a mercury thermometer or a thermocouple ( $J$ or $K$ Constanan). In many cases the discharge rate was only estimated.

If the well did not artesian flow or flow at a sufficient rate, then air-lifting was accomplished. Discharge rates are not controllable during this type of test. Only recovery data were valid for an evaluation. It is not practical to quantitatively evaluate well or reservoir parameters from the testing conducted during drilling. 
4.4.2 Artesian Flow Well Tests. Artesian flow, constant-rate, variable-head, well testing was conducted shortly after the completion of drilling at wells RRGE-1, -2, -3, and RRGP-5. The discharge rate was controlled by manually operated gate valves and measured by means of an in-line orifice plate with a differential pressure instrument across the orifice. Measurement of change in wellhead pressure during drawdown and recovery utilized either a wellhead Heise gauge, a Paroscientific digiquartz pressure gauge, or a Hewlett-Packard temperature-compensated downhole pressure probe. Discharge temperature was recorded using a mercury thermometer, a platinum resistance thermometer, and/or a thermocouple installed in the discharge line.

The advantage of the artesian flow well test is the low cost. Good quality data obtained from these tests permitted the calculation of well and aquifer parameters. It was determined that at the lower artesian flow discharge rates, the well and reservoir parameters appear to be better or more transmissive. This may be a function of the type of reservoir system at the Raft River. It was found that longer duration well tests were required when using wellhead pressure instrumentation.

Information obtained from these tests was used to size pumps and design the pump depth setting for higher discharge rate tests. In addition, the lower discharge rate test data were used to evaluate well productivity.

4.4.3 Pulse Tests. Pulse tests, as designed and conducted at the Raft River, are short-duration, constant-rate, variable-head discharge tests with recovery between each test. These tests are conducted at a wide range of discharge rates. The pumping and recovery phase for each pulse are equal in duration. The instrumentation used for pulse testing at the Raft River was the same as previously discussed, except at higher discharge rates when a pump was used, a bubbler tube was used to show changes in annular water pressure.

Pulse testing was accomplished rather than conventional water well step testing, due to time-dependent density problems when changing discharge rates. Pulse testing at the Raft River also differs from petroleum pulse testing by the duration of each pulse (at Raft River the shortest pulse duration was $8+$ hours), and by the distance to the monitoring point (at Raft River no additional wells were monitored). This form of testing proved useful at Raft River for evaluation of well parameters and preliminary reservoir data.

4.4.4 Pump and Injection Tests. Pump and injection testing have been conducted at most Raft River exploration, production, and injection wells. This testing used electric-powered submersible and turbine shaft pumps, restricting the discharge rates to the design limitations of the particular pump. This restricted the production and injection rates to the high rates required for operating the $5 \mathrm{MW}(\mathrm{e})$ power plant. Using pumps in the well bore of the Raft River wells limited the ability to obtain downhole data. It was typical to measure drawdown/recovery in a production well by using a bubbler tube and surface gauge and build-up/fall-off by a wellhead gauge. To reduce thermal shock in the transite pipeline, most wells were artesian flowed through the pipeline prior to starting of the pump test. Wellhead pressure rose and then stabilized as function of wellbore fluid density. Thus, "initial" cold or hot wellhead pressures are of questionable value. (Additional discussion concerning preheating of wells will follow in Section 4.4.6.) No recovery was accomplished before starting the higher discharge rate pump test.

Well testing, with the primary goal of reservoir evaluation, were conducted for greater than 500 hours duration of pumping and injecting. Recovery data were obtained for a much shorter period of time due to wellbore fluid density changes. Data were obtained in as many observation wells as possible. However, many of these observation wells were producing fluids at poorly regulated discharge rates for various reasons.

Numerous injection tests at reservoir temperatures, and a few at cooler-than-reservoir temperatures were conducted. No reservoir parameters could be calculated from the cool water injection tests due to the short duration and discharge rate control problems. Projected effects of injecting cooler water is desirable, as the SMW(e) power plant will cool the injection fluid. However, injection of cool water was used successfully for delineating production zones. 57 
4.4.5 Interference Tests. Interference testing is the measurement of pressure response from a production/injection well at some distant observation well(s). Data collected from an inactive observation well produce data unavailable by any other technique. These data may, under favorable circumstances, be used to determine the average transmissivity of a large volume of the reservoir. The data also have the advantage of not being thermally affected. However, if the observation well is producing fluids, as was the case in many of the tests at the Raft River, the data may be meaningless. Also, the distance to the observation well effects the required duration of the production/injection test, dependent on reservoir parameters.

4.4.6 Preheating. As discussed previously, preheating of wells by low discharge, natural artesian, and flow rates were required to prevent thermal shock in the transite pipeline. This procedure also reduced the time required to reach an isothermal discharge at the higher discharge rate tests. Although the procedure affects the cold wellhead pressure, it appears to be advantageous for evaluating a well or reservoir when wellhead data are being obtained. Additional research is required.

4.4.7 Evaluation of Fractured Flow. Evaluation of a fractured flow reservoir is controversial in both the petroleum and ground water fields. The recommended analytical techniques range from using the standard Theis assumptions and equations for an anisotropic permeable medium ${ }^{63}$ to computer simulations of block responses. ${ }^{64}$ The latter technique suggests that use of the Theis solution in analyzing pump test data from fractured reservoirs can yield grossly erroneous values of reservoir parameters.

The Raft River pump test data are complicated not only by a fracture flow system, but also by several hundred minutes of thermally effected wellhead data. However, after early-time well and thermal effects are past, the production and injection well drawdown/build-up typically approaches a straight line on a semi-logarithmic plot. Since early-time data are not analyzable at the Raft River, most well test analyses have not been used to calculate the standard reservoir parameters. Instead, the straight line slope of the data over one log cycle $\left(s_{10}\right)$ divided by the discharge rate $(Q)$ has been used. The values of $Q / s_{10}$ are not a reservoir parameter, but do allow for comparison between wells in a reservoir.

4.4.8 Test Equipment. All nonpumping production wells observed during tests used a Heise guage and either a 0 - to 1379-kPaa digiquartz pressure transducer with a digital tape printout or a Hewlett-Packard temperature-compensated downhole pressure probe. This instrument records simultaneous pressure and temperature measurements using a 2813-B quartz pressure tool coupled to a 401 pressure computer processor. The instrument has a temperature range of -15 to $150^{\circ} \mathrm{C}$ and maximum pressure rating of $103 \mathrm{mPa}$. Similar surface instrumentation was installed in monitor wells 1 and 2 which have flowing artesian heads. Wellhead pressures at injection wells RRGI-6 and -7, during injection tests, were monitored with similar instruments up to pressures of $1379 \mathrm{kPaa}$. Additional measurements were recorded at the injection wellheads using a 0 to 6895-kPag Heise gauge and a Rosemont D6895 kPag pressure transmitter interfaced to a Hewlett-Packard strip chart recorder when pressures exceeded the digiquartz capacities.

Fluid levels in the pumped production wells RRGE-1, -2, -3, and RRGP-5 were measured using bubbler tubes attached to the pump column to a depth close to the pump intake. The fluid in the bubbler tube was displaced by purging periodically with nitrogen. Displacement pressure in the tube was measured by a 0 to 6895-kPag Heise gauge in wells RRGE-2, -3, and RRGP-5. This gauge is precise to $7 \mathrm{kPag}$. Digiquartz instruments measured wellhead pressure in the annulus, a space surrounding the pump discharge columns. These instruments provided only potentiometric fluid levels under confined, shut-in conditions. Digiquartz instruments record absolute pressure rather than gauge pressure.

Fluid levels in the nonflowing monitor wells MW-3, $-4,-5,-6$, and -7 were measured by Stevens Type F water level recorders with periodic steel tape readings for control.

Fluid discharge rates were regulated in all the early tests and in most exploration/production wells by a manually operated gate valve. The discharge rate was typically measured by differential pressure across an in-line orifice plate at wells RRGI-6 and RRGI-7. Fisher valve with Cavitol trim was used to control flow at RRGI-6 and RRGI-7. This valve relied on a Rosemont differential pressure transmitter, sensing differential pressure across an in-line circular orifice. Pressure differential across the orifice was recorded on a Hewlett-Packard strip chart recorder. 
An experimental, custom-built, four butterfly valve hydroelectric controller was used for a while on RRGP-5. However, the resolution of flow rate control was unacceptable. The valve set was later removed.

Wellhead temperatures at production and injection wells were measured by in-line $J$ and $K$ Constantan thermocouples, recorded on Soltee strip chart recorders. In-line mercury thermometers provided backup temperature data. Platinum resistance thermometers have also been used. Temperature profiles were run in injection wells RRGI-6 and RRGI-7 during selected tests. The instrument used was a probe run on single conductor cable through wellhead lubricators.

\subsection{Well Field Analysis}

4.5.1 Well RRGE-1. A list of all well tests run at RRGE-1 are in Table 15. A discussion of these $\leq 24$-hour tests follows.

A short-term artesian flow test was conducted between November 5 to 6, 1975. After making observations on background reservoir pressure for about 18 hours, the well was artesian flowed at an average discharge of $1.7 \mathrm{~L} / \mathrm{s}$ for a period of 30 hours. After shutting down flow, pressure buildup was monitored for approximately 19 hours. During the test, the downhole pressure instrument was positioned at a depth of $731.5 \mathrm{~m}$ within the well. The time history of pressure change is graphically presented in Figure 19 . The reservoir parameters for the drawdown phase are: $\mathrm{Q} / \mathrm{s}_{10}=1.2(\mathrm{~L} / \mathrm{s}) /(\mathrm{kPa}) / \log$ cycle, $\mathrm{kH}_{\mathrm{a}} \cong 47300 \mathrm{mD} \cdot \mathrm{m}, \mathrm{T}_{\mathrm{a}}=2 \times 10^{-3} \mathrm{~m}^{2} / \mathrm{s}$. Recovery is graphically presented in Figure 20 . The break in the slope was attributed to masking effects of earth tides. 65 The reservoir parameters for the recovery phase are: $\mathrm{Q} / \mathrm{s}_{10}=0.63(\mathrm{~L} / \mathrm{s}) /(\mathrm{kPa}) / \mathrm{log}$ cycle, $\mathrm{kH}_{\mathrm{a}} \cong 24000 \mathrm{mD} \cdot \mathrm{m}, \mathrm{T}_{\mathrm{a}}=1 \times 10^{-3} \mathrm{~m}^{2} / \mathrm{s}$. The reservoir parameters for the recovery phase are of questionable value. No-time-versus temperature data were recorded at the surface. The maximum pressure drawdown at the end of 30 hours of production was approximately $7.6 \mathrm{kPa}$. Additional details of the test are described by Narasimhan et al. 65

A longer-duration test was conducted between February 2 and 6,1976 . The well was pumped at an average discharge of $55.5 \mathrm{~L} / \mathrm{s}$ for a period of 99 hours. During the test, drawdown was recorded by bubbler tube pressure. The time history of pressure change is graphically presented in Figure 21. The reservoir parameters for the drawdown phase are: $Q / s_{10}=0.5(\mathrm{~L} / \mathrm{s}) /(\mathrm{kPa}) / \log$ cycle, $\mathrm{kH}_{\mathrm{a}}=20600 \mathrm{mD} . \mathrm{m}$, and $\mathrm{T}_{\mathrm{a}}=9.2 \times 10^{-2} \mathrm{~m}^{2} / \mathrm{s}$. Neither recovery data nor time-versus-discharge temperature were analyzed. The data and analysis appear questionable.

Table 15. Well RRGE-1 performance testing activity

\begin{tabular}{|c|c|c|c|c|}
\hline Description & Date & $\begin{array}{c}\text { Duration } \\
\text { (hr) } \\
\end{array}$ & $\begin{array}{l}\text { Rate } \\
(\mathrm{L} / \mathrm{s})\end{array}$ & Type \\
\hline Short-term well test ${ }^{a}$ & $11 / 05 / 75$ & 30 & 1.7 & Artesian flow \\
\hline Sustained well test & $02 / 02 / 76$ & 99 & 55 & Pump test \\
\hline $\begin{array}{l}\text { Attempted long-term } \\
\text { production/injection test: } \\
\text { RRGE-1 to RRGI-7 }\end{array}$ & $\begin{array}{l}10 / 12 / 79 \\
10 / 15 / 79\end{array}$ & 8 & $\begin{array}{l}75.6 \\
63\end{array}$ & $\begin{array}{l}\text { Pulse pump } \\
\text { test } \\
\text { Pump test }\end{array}$ \\
\hline $\begin{array}{l}\text { Production/injection test: } \\
\text { RRGE-1 to RRGI-6 and RRGI-7 }\end{array}$ & $08 / 18 / 80$ & 500 & 56.8 & Pump test \\
\hline
\end{tabular}




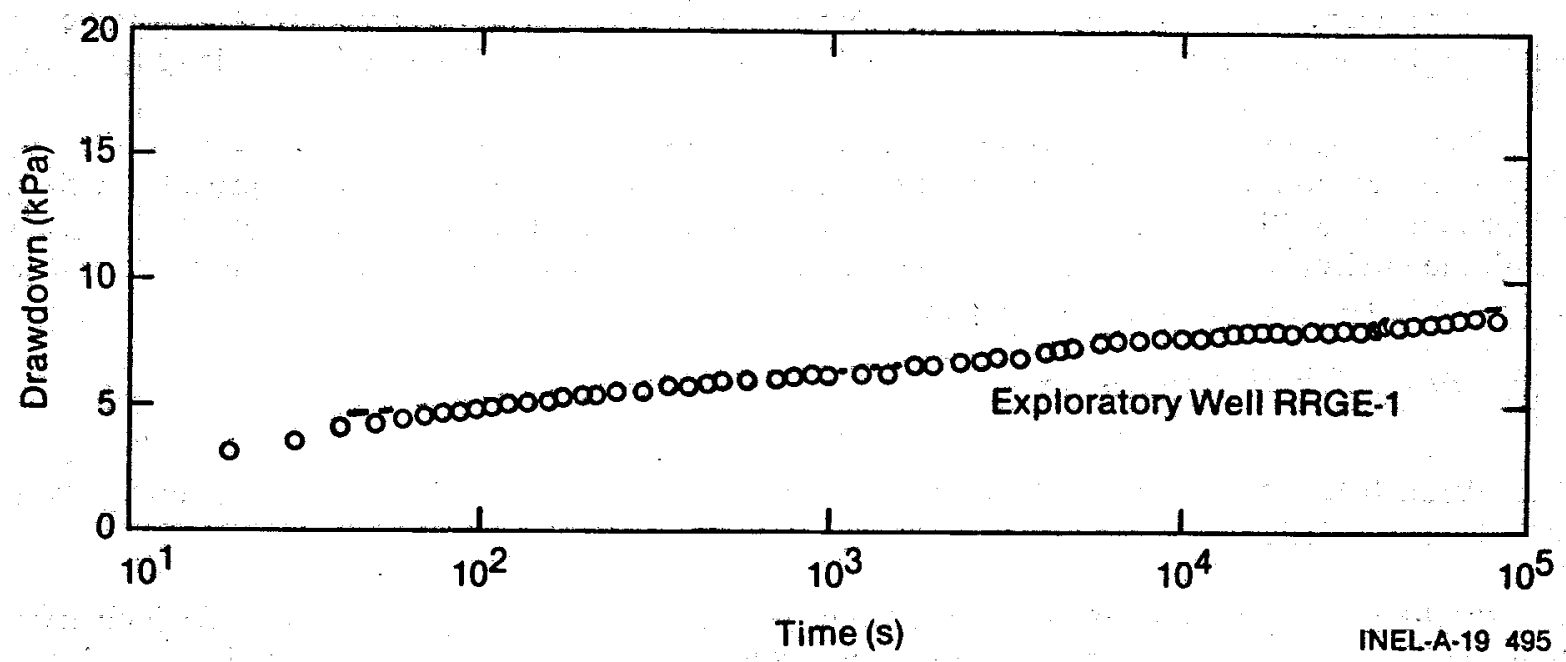

Figure 19. Drawdown during production test of well RRGE-1, November 5, 1975, at a discharge rate of $1.7 \mathrm{~L} / \mathrm{s}$ for 30 continuous hours. Data obtained with downhole pressure probe (abstracted from Reference 65).

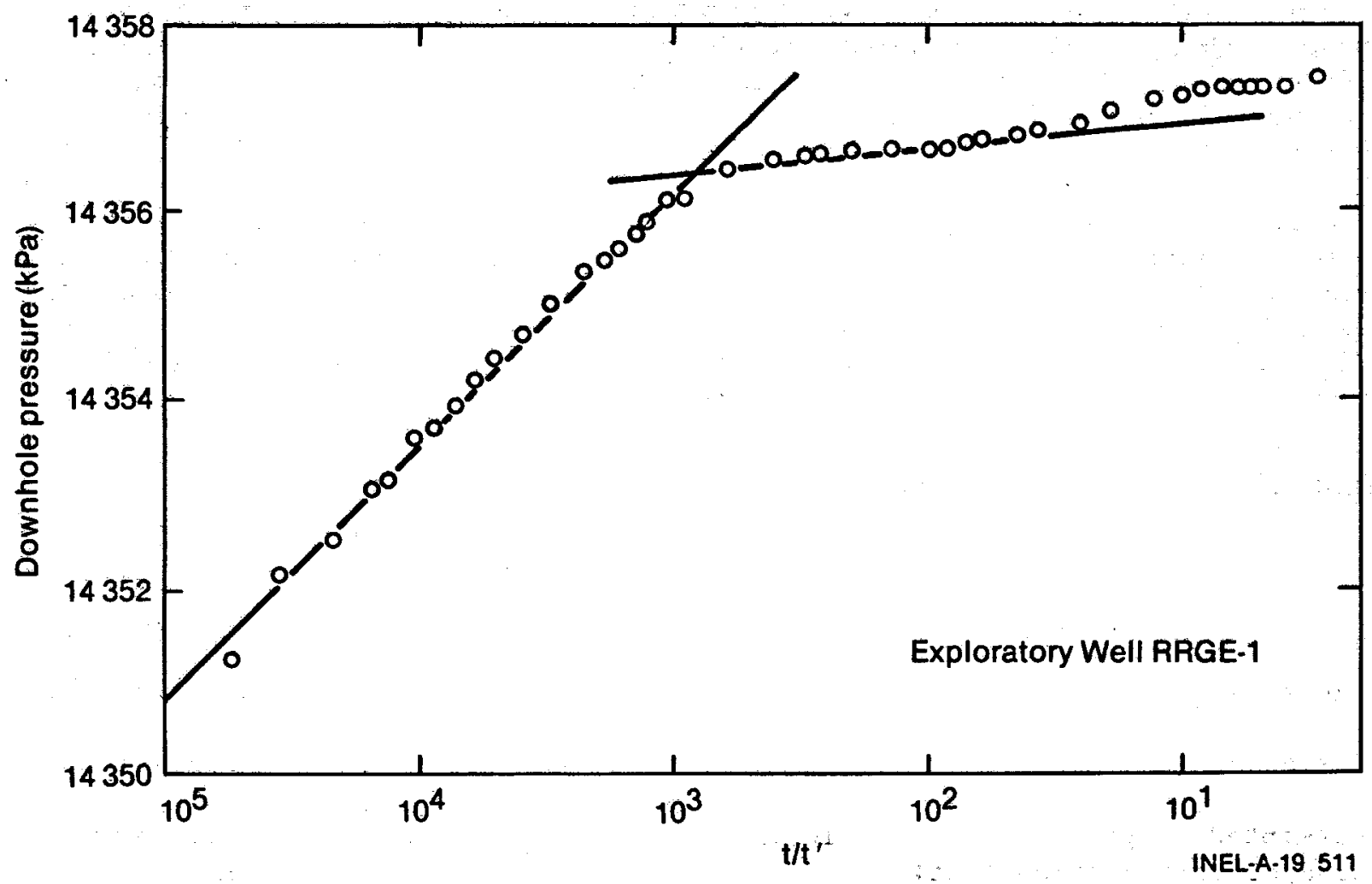

Figure 20. Recovery from production test of well RRGE-1, November 5, 1975, at a discharge rate of $1.7 \mathrm{~L} / \mathrm{s}$ for 30 continuous hours. Data obtained with downhole pressure probe (abstracted from Reference 65). 


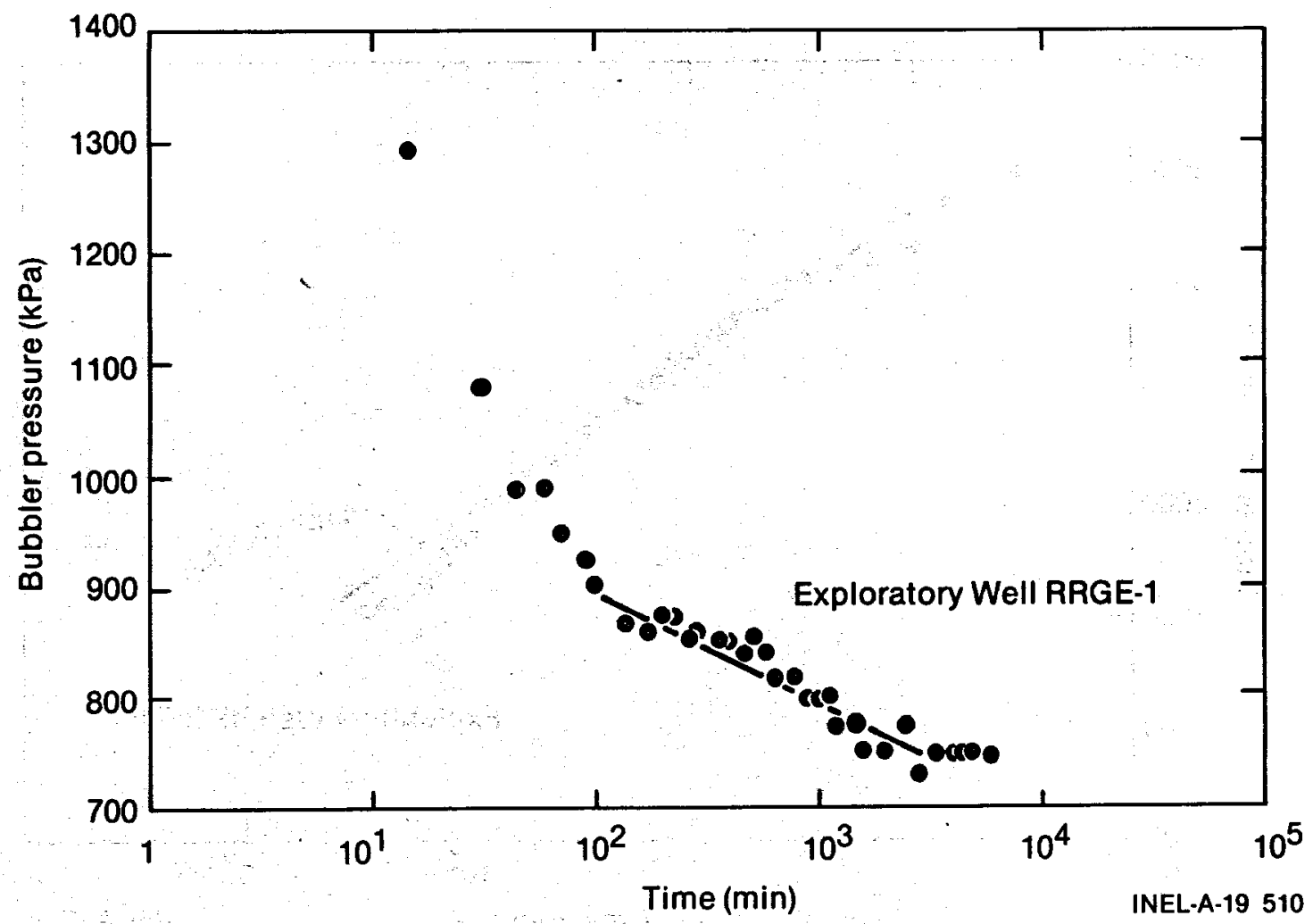

Figure 21. Drawdown during production test of well RRGE-1, February 2, 1976, at a discharge rate of $55.5 \mathrm{~L} / \mathrm{s}$, for 99 continuous hours. Initial wellhead pressure was $1200 \mathrm{kPa}$.

Another intermediate-duration test was conducted between October 15 and 18,1979 . The well was pumped at an average discharge of $63 \mathrm{~L} / \mathrm{s}$ for a period of 80 hours. During the test, drawdown and recovery were obtained by bubbler tube pressure. The initial bubbler tube pressure was $6136 \mathrm{kPa}$. After 300 min of testing, pump difficulties caused a $14-m i n$ period of recovery. The time history of pressure change during the drawdown phase is graphically presented in Figure 22. The reservoir parameters for drawdown phase are: $\mathrm{Q} / \mathrm{s}_{10}=0.086(\mathrm{~L} / \mathrm{s}) /(\mathrm{kPa}) / \mathrm{log}$ cycle, $\mathrm{kH}_{\mathrm{a}}=3300 \mathrm{mD} \cdot \mathrm{m}$, and $\mathrm{T}_{\mathrm{a}}=1.5 \mathrm{x}$ $10^{-4} \mathrm{~m}^{2} / \mathrm{s}$. The recovery phase is graphically presented in Figure 23 . Reservoir parameters for the recovery phase are: $\mathrm{Q} / \mathrm{s}_{10}=0.21(\mathrm{~L} / \mathrm{s}) /(\mathrm{kPa}) / \log$ cycle, $\mathrm{kH}_{\mathrm{a}}=8200 \mathrm{mD} \cdot \mathrm{m}$, and $\mathrm{T}_{\mathrm{a}}=3.7 \times 10^{-4} \mathrm{~m}^{2} / \mathrm{s}$. No wellhead temperature-versus-time was reported. The maximum bubbler tube drawdown of $2.6 \times 10^{3} \mathrm{kPa}$ was reached before the pump difficulties at $300 \mathrm{~min}$.

A long-duration test was conducted between August 18, 1980 and September 10, 1980. The well was pumped initially at a rate of $66.2 \mathrm{~L} / \mathrm{s}$ but declined to $56.8 \mathrm{~L} / \mathrm{s}$ within the first $100 \mathrm{~min}$ of the test. Drawdown and recovery data were recorded by use of a bubbler tube and Heise pressure gauge. The initial bubbler tube pressure was not recorded, but is estimated to be about $6.1 \times 10^{3} \mathrm{kPa}$ (hot). During the test there were several pump outages of short duration. The time history of pressure change during drawdown is graphically presented in Figure 24 . Well parameters for the drawdown phase are: $Q / s_{10}=$ $0.28(\mathrm{~L} / \mathrm{s}) /(\mathrm{kPa}) / \log$ cycle, $\mathrm{kH}_{\mathrm{a}}=10900 \mathrm{mD} . \mathrm{m}$, and $\mathrm{T}_{\mathrm{a}}=4.9 \times 10^{-4} \mathrm{~m}^{2} / \mathrm{s}$. Recovery is graphically presented in Figure 25 . Well parameters for the recovery phase are: $Q / s_{10}=0.24(\mathrm{~L} / \mathrm{s}) /(\mathrm{kPa}) / \log$ cycle, $\mathrm{kH}_{\mathrm{a}}=9300 \mathrm{mD} . \mathrm{m}$, and $\mathrm{T}_{\mathrm{a}}=4.2 \times 10^{-4} \mathrm{~m}^{2} / \mathrm{s}$. No time-versus-discharge temperature was reported. The maximum bubbler tube drawdown was about $2068 \mathrm{kPa}$. A summary of the calculated well parameters for those well tests of 724 hours in duration is presented in Table 16 . If the data from the $2 / 2 / 76,55-\mathrm{L} / \mathrm{s}$ test are not considered, then it appears that at low discharge rates the apparent well parameters are considerably higher than at the high discharge rates. Although well parameters should be a constant, this may not hold in the case of a fractured reservoir. 


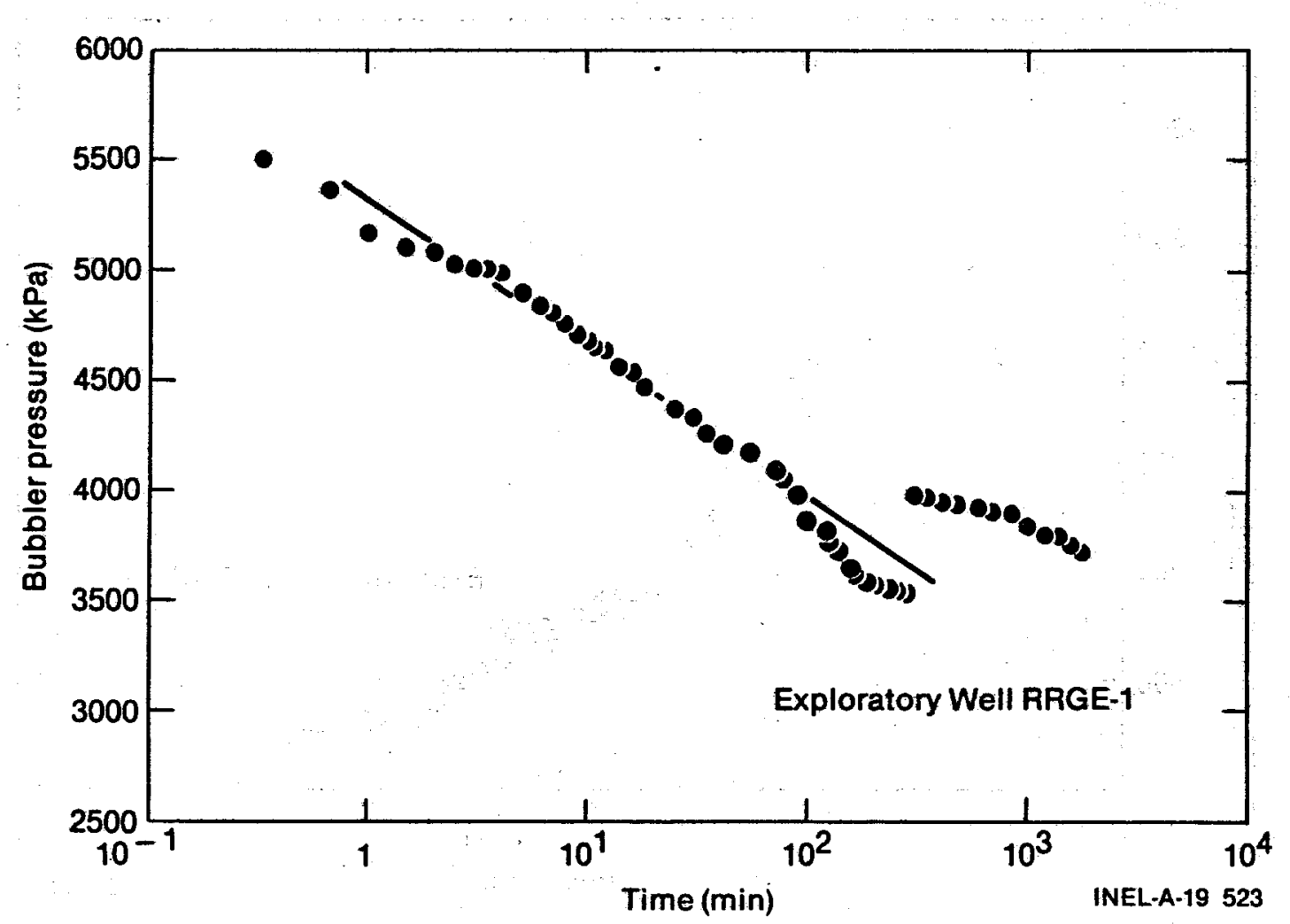

Figure 22. Drawdown during production test of well RRGE-1, October 15, 1979 at a discharge rate of $63 \mathrm{~L} / \mathrm{s}$ for 80 hours with one 14 minute pause after 300 minutes. Maximum discharge temperature was $142^{\circ} \mathrm{C}$.

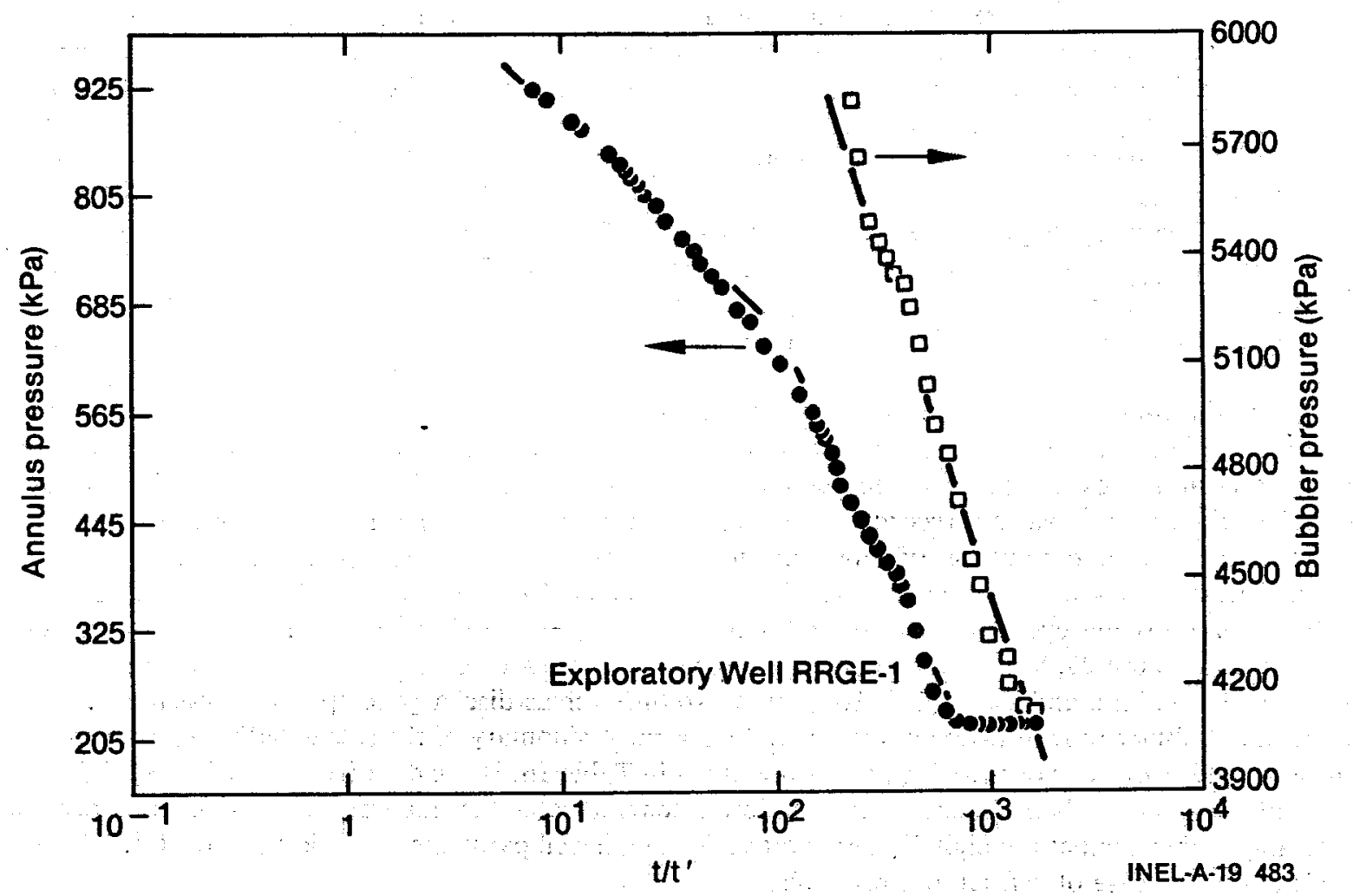

Figure 23. Recovery from production test of well RRGE-1, October 15, 1979 at a discharge rate of $63 \mathrm{~L} / \mathrm{s}$ for 80 hours with one 14 minute pause after 300 minutes. 


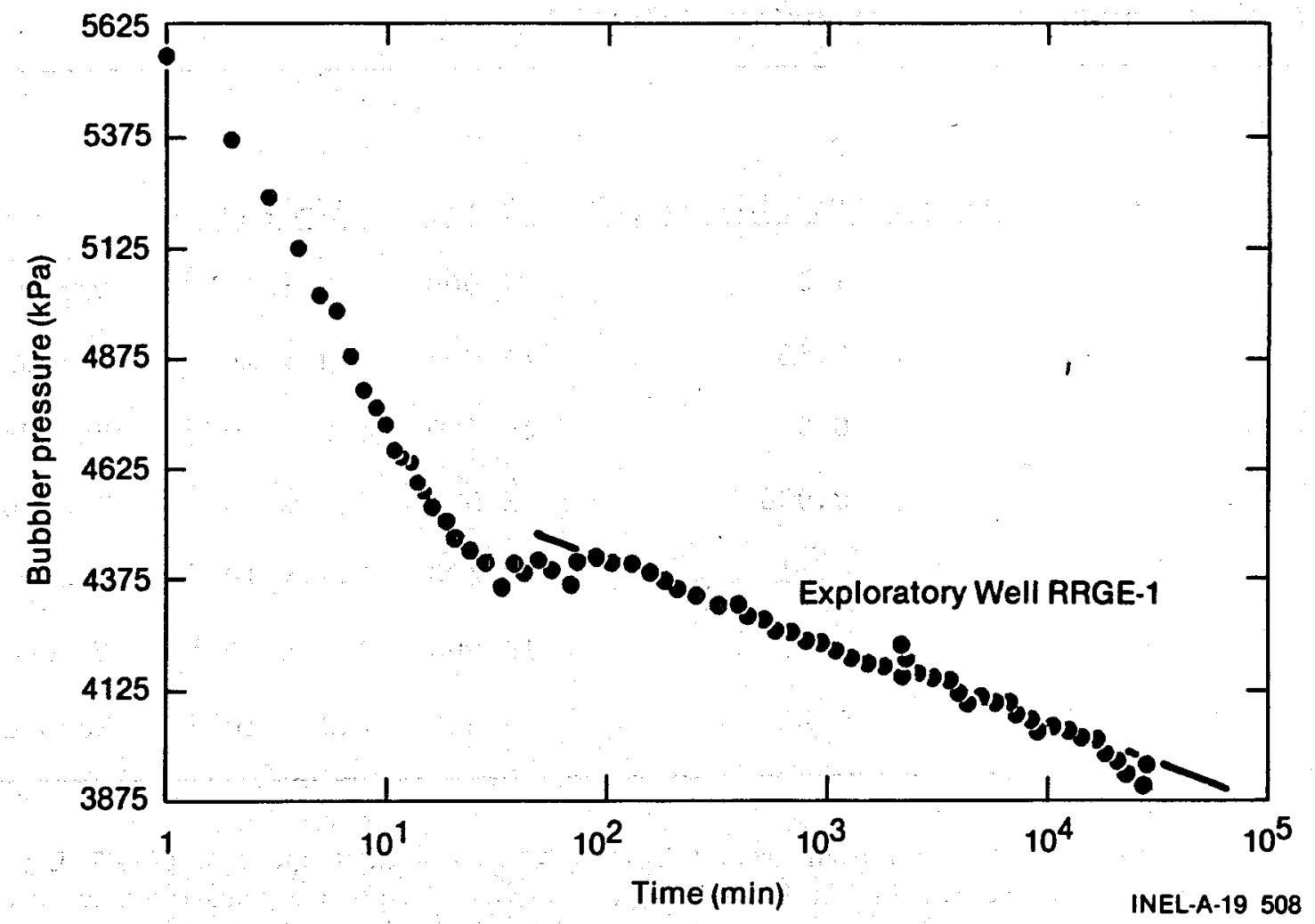

Figure 24. Drawdown during production test of well RRGE-1, August 18, 1980 at an average discharge rate of $61.5 \mathrm{~L} / \mathrm{s}$. During the test there were numerous pump outages.

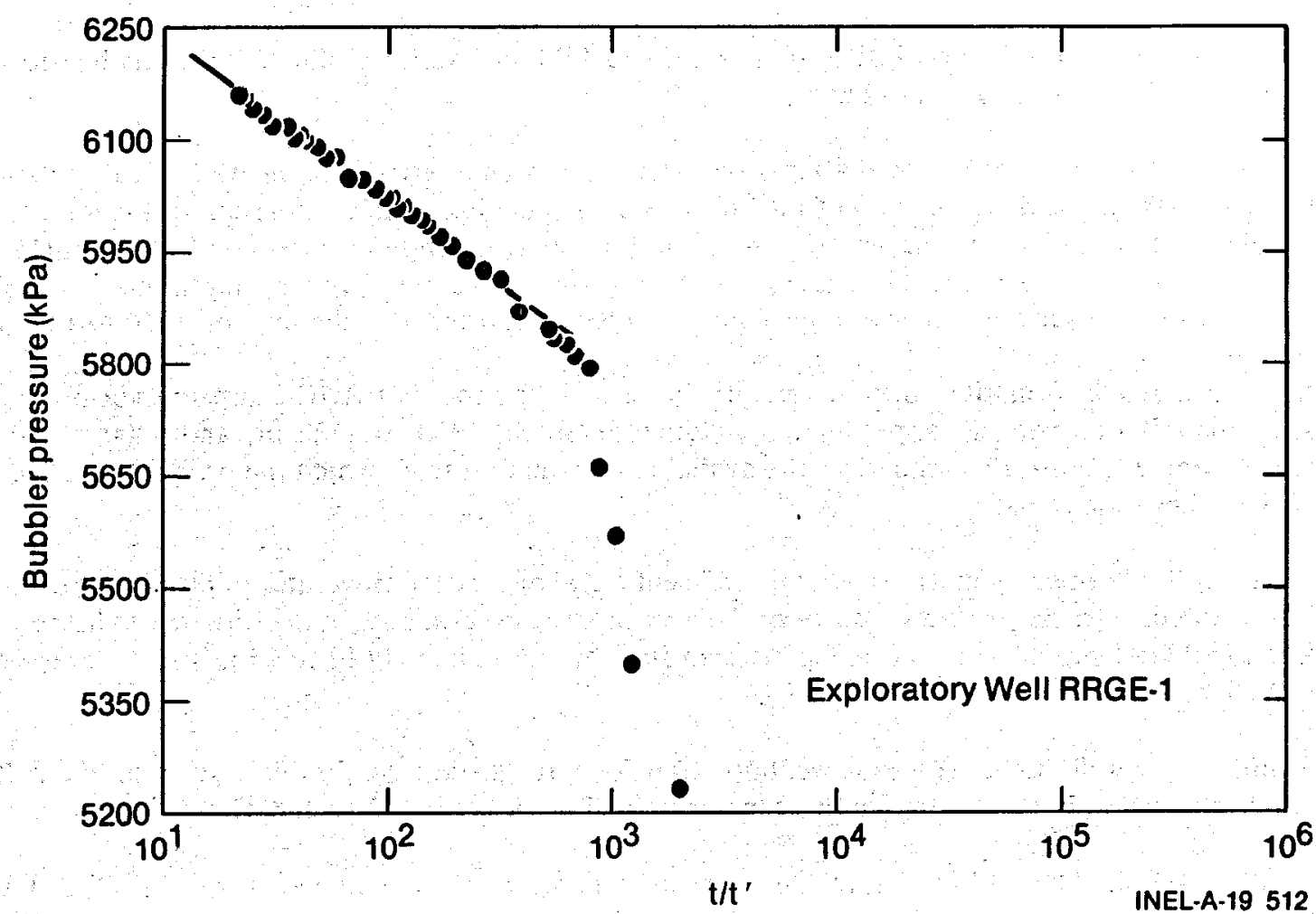

Figure 25. Recovery from production test of well RRGE-1, August 18, 1980 at an average discharge rate of $61.5 \mathrm{~L} / \mathrm{s}$. 
Table 16. Summary of well parameters at RRGE-1

\begin{tabular}{|c|c|c|c|c|c|}
\hline Date & $\begin{array}{c}Q \\
(L / s) \\
\end{array}$ & $\begin{array}{c}Q / \mathrm{s} / 0 \\
{\left[(\mathrm{~L} / \mathrm{s}) /(\mathrm{kPa}) / \log _{\text {cycle }}\right]}\end{array}$ & $\begin{array}{c}\mathrm{kH}_{\mathrm{a}} \\
\left(\mathrm{mD}^{\circ} \mathrm{m}\right) \\
\end{array}$ & $\begin{array}{c}\mathrm{T}_{\mathrm{a}} \\
\left(\mathrm{m}^{2} / \mathrm{s}\right) \\
\end{array}$ & Test \\
\hline \multirow[t]{2}{*}{$11 / 05 / 75$} & 1.7 & 1.2 & 47000 & $2 \times 10^{-3}$ & Drawdown \\
\hline & & 0.63 & 24000 & $1 \times 10^{-3}$ & Recovery \\
\hline $02 / 02 / 76$ & 55 & 0.5 & 20600 & $9.2 \times 10^{-3}$ & Drawdown \\
\hline \multirow[t]{2}{*}{$10 / 12 / 79$} & 63 & 0.086 & 3000 & $1.5 \times 10^{-4}$ & Drawdown \\
\hline & & 0.21 & 8200 & $3.7 \times 10^{-4}$ & Recovery \\
\hline \multirow[t]{2}{*}{$08 / 18 / 80$} & 56.8 & 0.28 & 10900 & $4.9 \times 10^{-4}$ & Drawdown \\
\hline & $y$ & 0.24 & 9300 & $4.2 \times 10^{-4}$ & Recovery \\
\hline
\end{tabular}

The 24-hour specific capacity ranged from $0.24(\mathrm{~L} / \mathrm{s}) / \mathrm{kPa}$ at a discharge rate of $1.7 \mathrm{~L} / \mathrm{s}$ to $0.03(\mathrm{~L} / \mathrm{s}) / \mathrm{kPa}$ at a discharge rate of $56.8 \mathrm{~L} / \mathrm{s}$. The specific capacity is apparently progressively smaller with higher rates. The productivity curve is plotted in Figure 26. Evaluation of the line between the two plotted points results in the equation $y=34.17 \times-51$.10. However, implications from 24-hour data suggest that the curve is a quadratic of the form $y=-0.23 x^{2}+13.37 x-15.05$. It is likely that the productivity curve is a quadratic due to the fractured nature of the reservoir.

The interval open to production in RRGE-1 is 1104 to $1521 \mathrm{~m}$. During drilling, fluid was lost to the formation in the interval of 1100 to $1220 \mathrm{~m}$.

Temperature gradient changes, noted after cooler water had been injected into the well, occur at depths of $1201,1230,1300 \mathrm{~m}$ and in the interval of 1406 to $1423 \mathrm{~m}$. Caliper logs indicate hole enlargement through the interval of 1140 to $1175 \mathrm{~m}$ and several thin zones of hole enlargement in the interval of 1406 to $1415 \mathrm{~m}$. No flow meter surveys are available to assess producing zones. Fractured zones, interpreted from the available USGS televiewer logs occur at approximately $1300 \mathrm{~m}$ and through the interval 1400 to $1496 \mathrm{~m}$.

From the available information, the most significant producing zones in RRGE-1 appear to be probable fractured intervals occurring at approximately 1190 to $1230 \mathrm{~m}, 1300$ to $1320 \mathrm{~m}$, and $1400 \mathrm{~m}$ in the borehole. Section 3, Figure 12 summarizes the available information from which the probable producing intervals have been identified.

RRGE-1 has not been adequately tested at a sufficient range of artesian flow rates to predict its artesian capability with confidence. From its history of flow to support experiments, it is estimated that the well should be capable of supporting a sustained artesian flow of approximately 12 to $15 \mathrm{~L} / \mathrm{s}$ for a three-year period. Wellhead flowing temperature is $135^{\circ} \mathrm{C}$.

An estimation of well discharge-versus-wellbore drawdown from static conditions is given in Figure 27. At the higher rates $(30 \mathrm{~L} / \mathrm{s})$, the discharge temperature will be between 132 to $138^{\circ} \mathrm{C}$.

4.5.2 Well RRGE-2. Table 17 lists all of the reservoir evaluation tests conducted at well RRGE-2. Each of the tests that lasted in excess of 24 hours will be reviewed and their reservoir characteristics will be presented. 


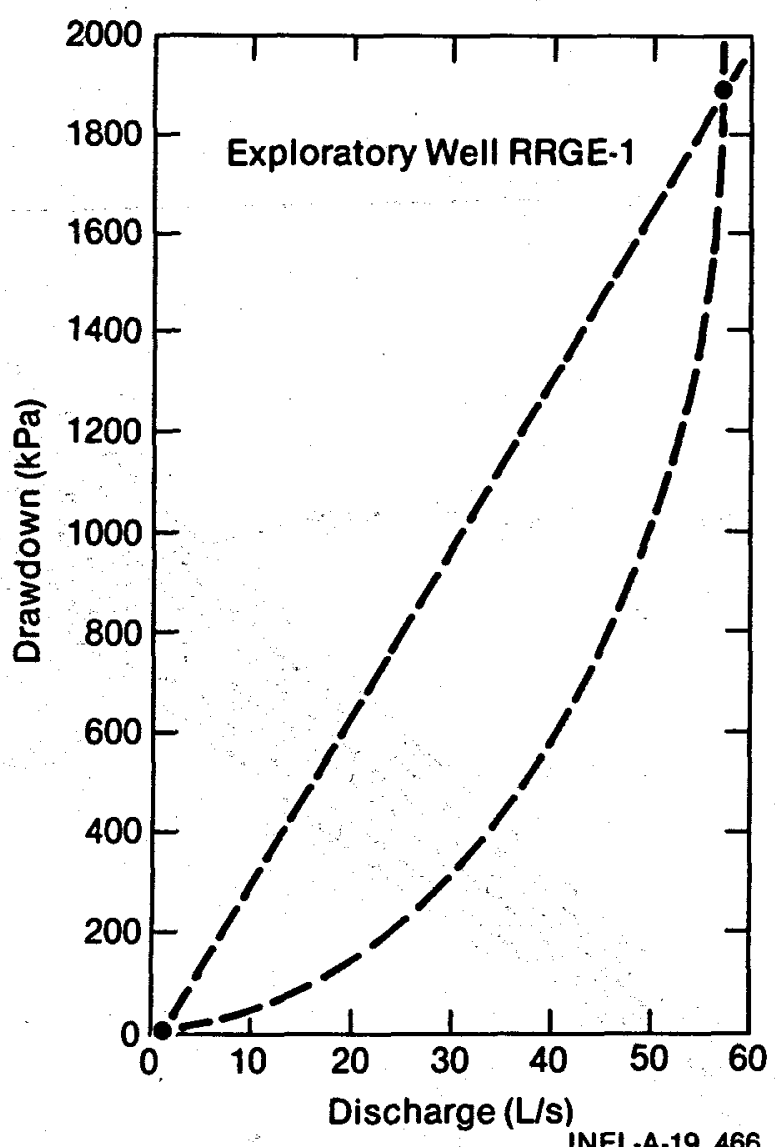

Figure 26. Productivity curve of 24-hour data from exploratory well RRGE-1.

During 1977, several pulse-type production tests were made at Well RRGE-2. Each was conducted in a similar manner and each was instrumented with a wellhead pressure gauge. Most of these tests lasted 24 hours. Figure 28 is a semi-log plot of pressure response observed during these tests. The reservoir characteristics resulting from these tests are presented in Table 18. The use of wellhead instrumentation when testing wells in which the production fluid varies in temperature complicates analysis of pressure observations; early time data are most severely affected. If sufficient data are obtained after thermal equilibrium is reached in the borehole, an analysis can be conducted with reasonable confidence.

The pressure recovery of RRGE-2 was observed following the artesian pulse test of February 17, 1977. Figure 29 contains a semi-log plot of this recovery. Reservoir characteristics obtained from this test are: $\mathrm{kH}_{\mathrm{a}}=2700 \mathrm{mD} . \mathrm{m} ; \mathrm{T}_{\mathrm{a}}=1.2 \times 10^{-4}, \mathrm{~m}^{2} / \mathrm{s} ; \mathrm{Q} / \mathrm{s} 10=0.07(\mathrm{~L} / \mathrm{s}) /(\mathrm{kPa}) / \mathrm{log}$ cycle. These values are approximately $50 \%$ smaller than the values obtained from the production test.

The May 30, 1978 production test was the third longest performed on RRGE-2. Pressure and temperature data were collected at the wellhead during the test. Figure 30 shows the pressure drawdown observed. Temperature effects were noted prior to the 100-min point of the test, beyond $100 \mathrm{~min}$ temperature remained relatively constant at about $137^{\circ} \mathrm{C}$. The sharp change in slope after $500 \mathrm{~min}$ of production may represent the influence of a reservoir boundary. Reservoir characteristics suggested by the early-time data following temperature stabilization are: $\mathrm{kH}_{\mathrm{a}}=2900 \mathrm{mD} \cdot \mathrm{m}, \mathrm{T}_{\mathrm{a}}=1.3 \times 10^{-3} \mathrm{~m} / \mathrm{s}$, and $\mathrm{Q} / \mathrm{s}_{10}=0.75(\mathrm{~L} / \mathrm{s}) /(\mathrm{kPa}) / \log$ cycle. When late-time data (after $500 \mathrm{~min}$ ) are used to interpret reservoir characteristics, $\mathrm{kH}_{\mathrm{a}}=3500 \mathrm{mD} . \mathrm{m}, \mathrm{T}_{\mathrm{a}}=1.6 \times 10^{-4} \mathrm{~m}^{2} / \mathrm{s}$, and $\mathrm{Q} / \mathrm{s}_{10}=0.9(\mathrm{~L} / \mathrm{s}) /(\mathrm{kPa}) / \log$ cycle.

During the calendar year 1979, three tests were conducted at RRGE-2. The first of these began on January 9 and was designed to provide fluid for use in injection testing at RRGI-6. To diminish the effects of temperature and density variations in the injection test, RRGE-2 was produced at $6.3 \mathrm{~L} / \mathrm{s}$ under artesian 


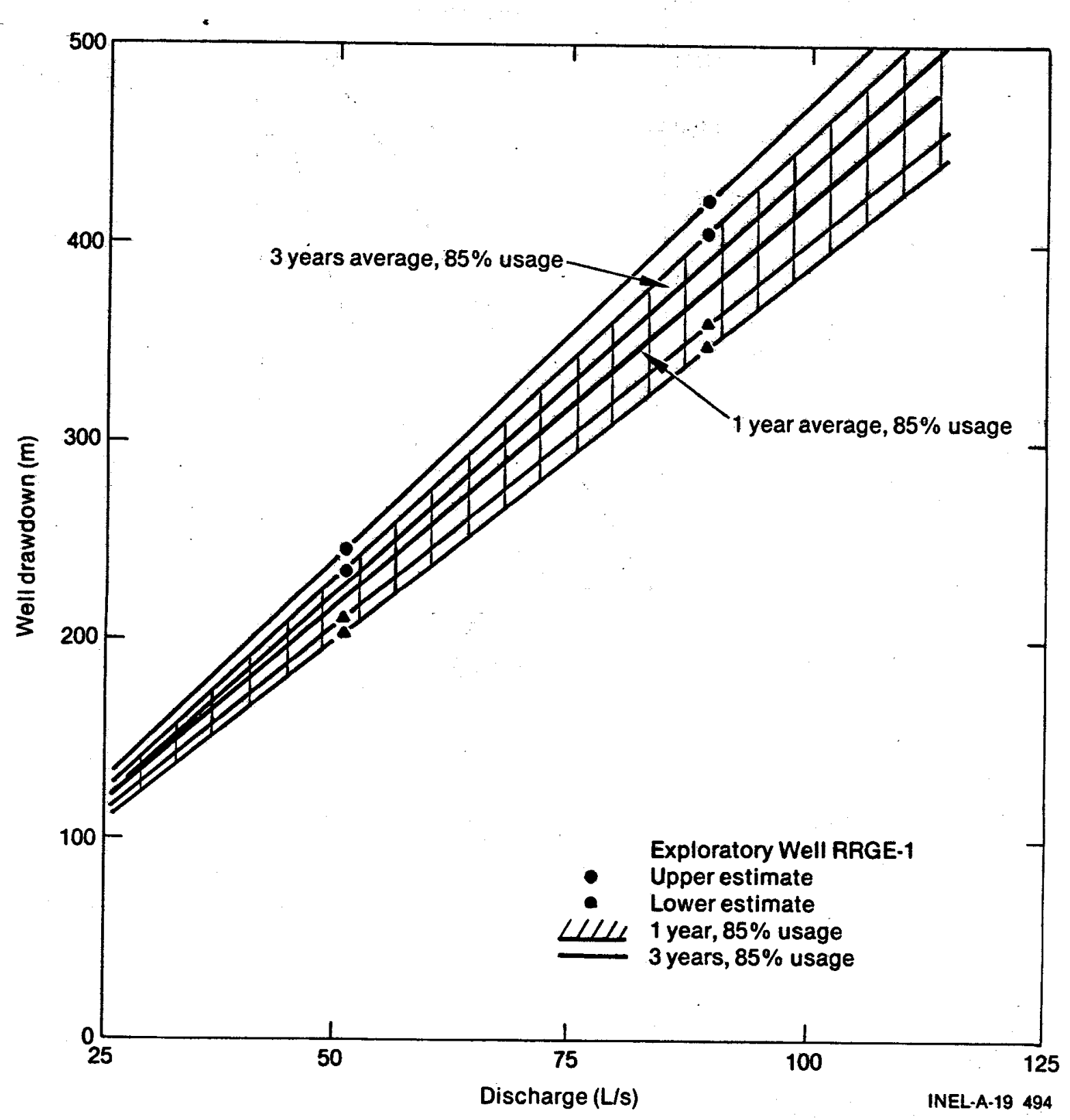

Figure 27. Expected drawdown versus flow rate at exploratory well RRGE-1 (not including interference effects). 
Table 17. Well RRGE-2 performance testing activity

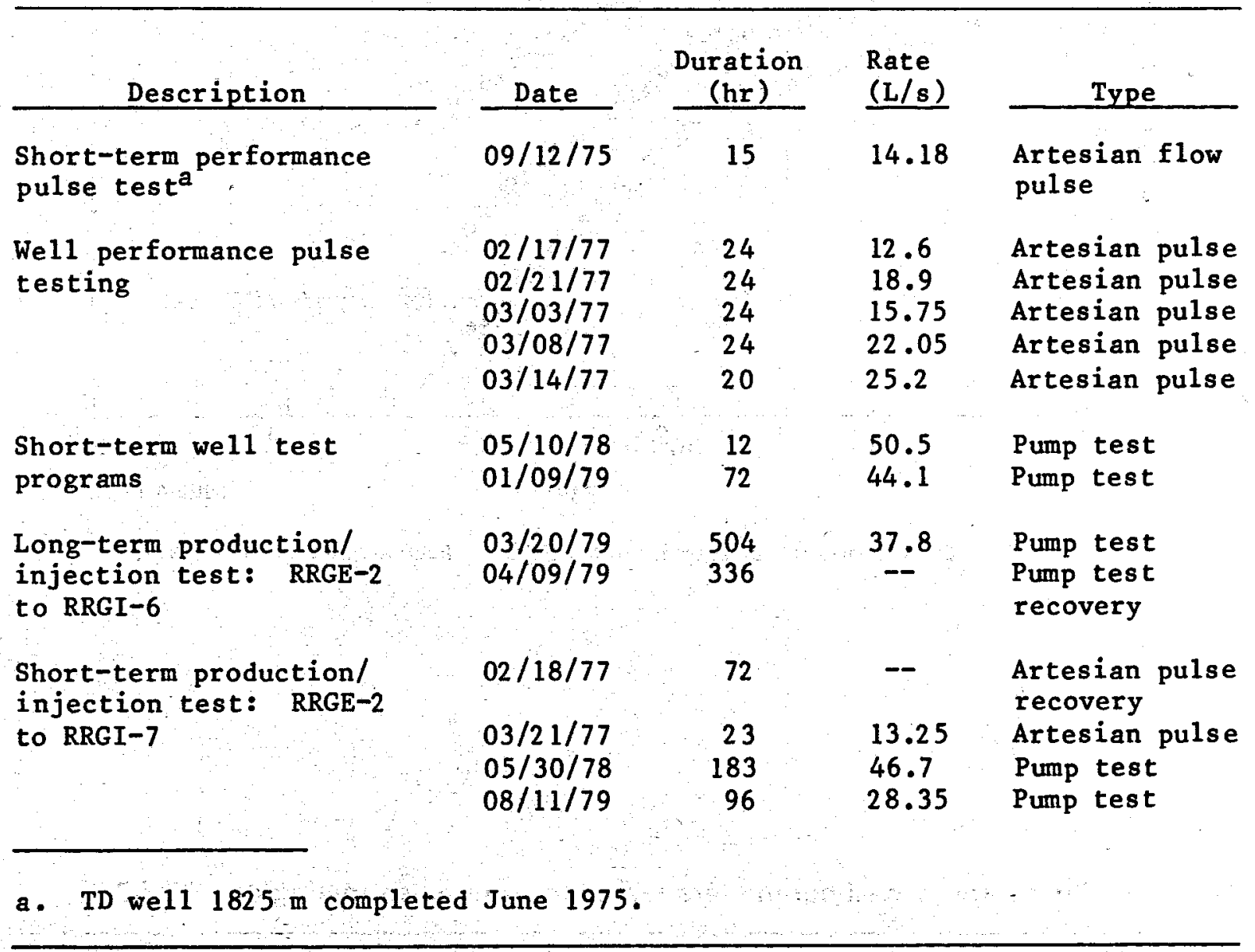




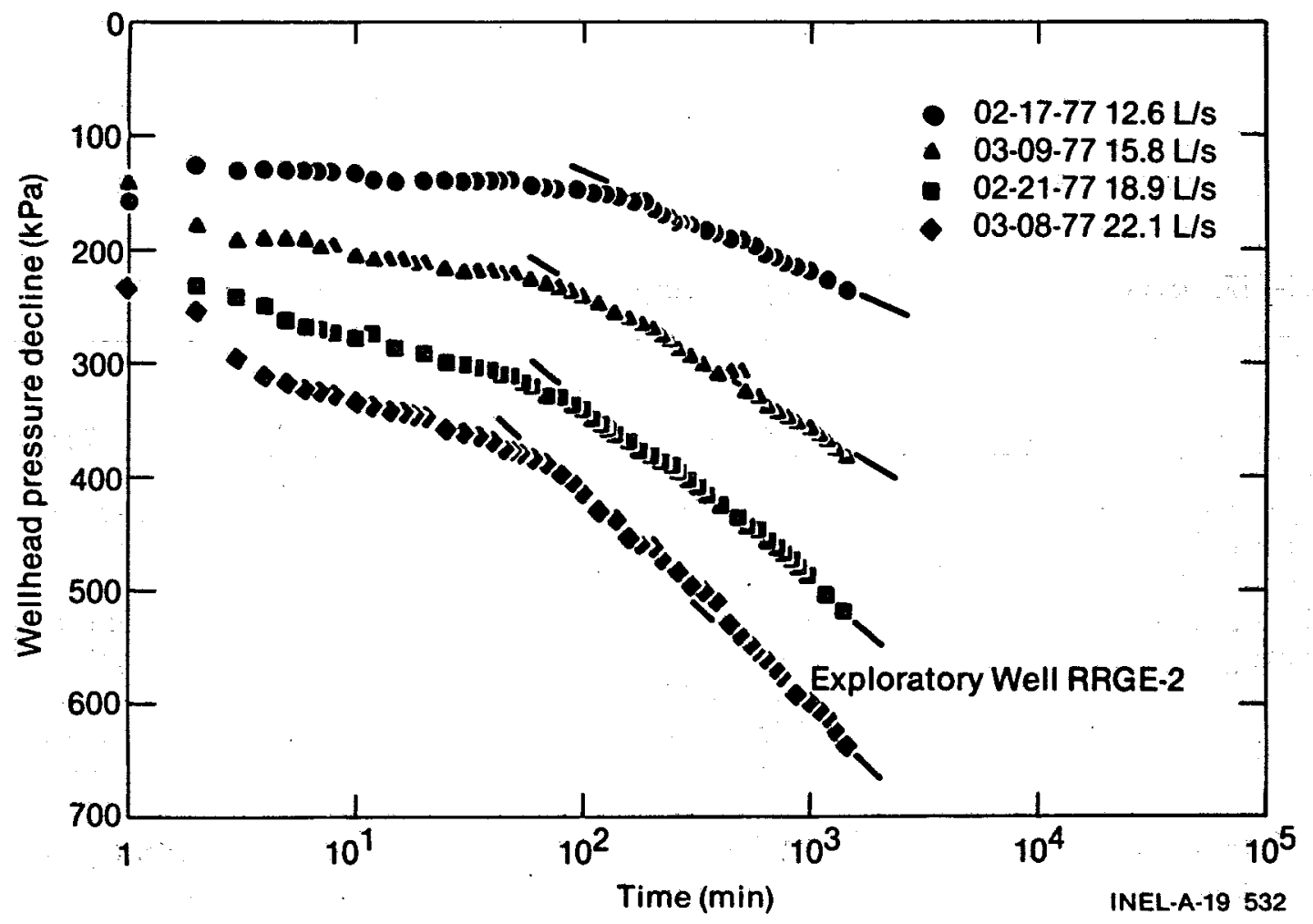

Figure 28. Drawdown during pulse testing of well RRGE-2, February through March 1977.

Table 18. Summary of well parameters resulting from pulse testing at RRGE-2

\begin{tabular}{|c|c|c|c|c|}
\hline Date & $\begin{array}{r}\mathrm{kH}_{\mathrm{a}} \\
\left(\mathrm{mD}^{\circ} \mathrm{m}\right) \\
\end{array}$ & $\begin{array}{c}T_{a} \\
\left(m^{2} / s\right) \\
\end{array}$ & $\begin{array}{c}\mathrm{s}_{10} \\
(\mathrm{kPa} / \log \text { cycle }) \\
\end{array}$ & $\begin{array}{c}Q / \mathrm{s} 10 \\
{[(\mathrm{~L} / \mathrm{s}) /(\mathrm{kPa}) / \log \text { cycle }]}\end{array}$ \\
\hline $\begin{array}{l}02 / 17 / 77 \\
02 / 21 / 77 \\
03 / 03 / 77 \\
03 / 08 / 77\end{array}$ & $\begin{array}{l}5600 \\
4600 \\
4900 \\
4300\end{array}$ & $\begin{array}{r}2.5 \times 10^{-4} \\
2 \times 10^{-4} \\
2.2 \times 10^{-4} \\
1.9 \times 10^{-4}\end{array}$ & $\begin{array}{r}86.2 \\
158.6 \\
122.7 \\
196.5\end{array}$ & $\begin{array}{l}0.15 \\
0.12 \\
0.13 \\
0.11\end{array}$ \\
\hline
\end{tabular}




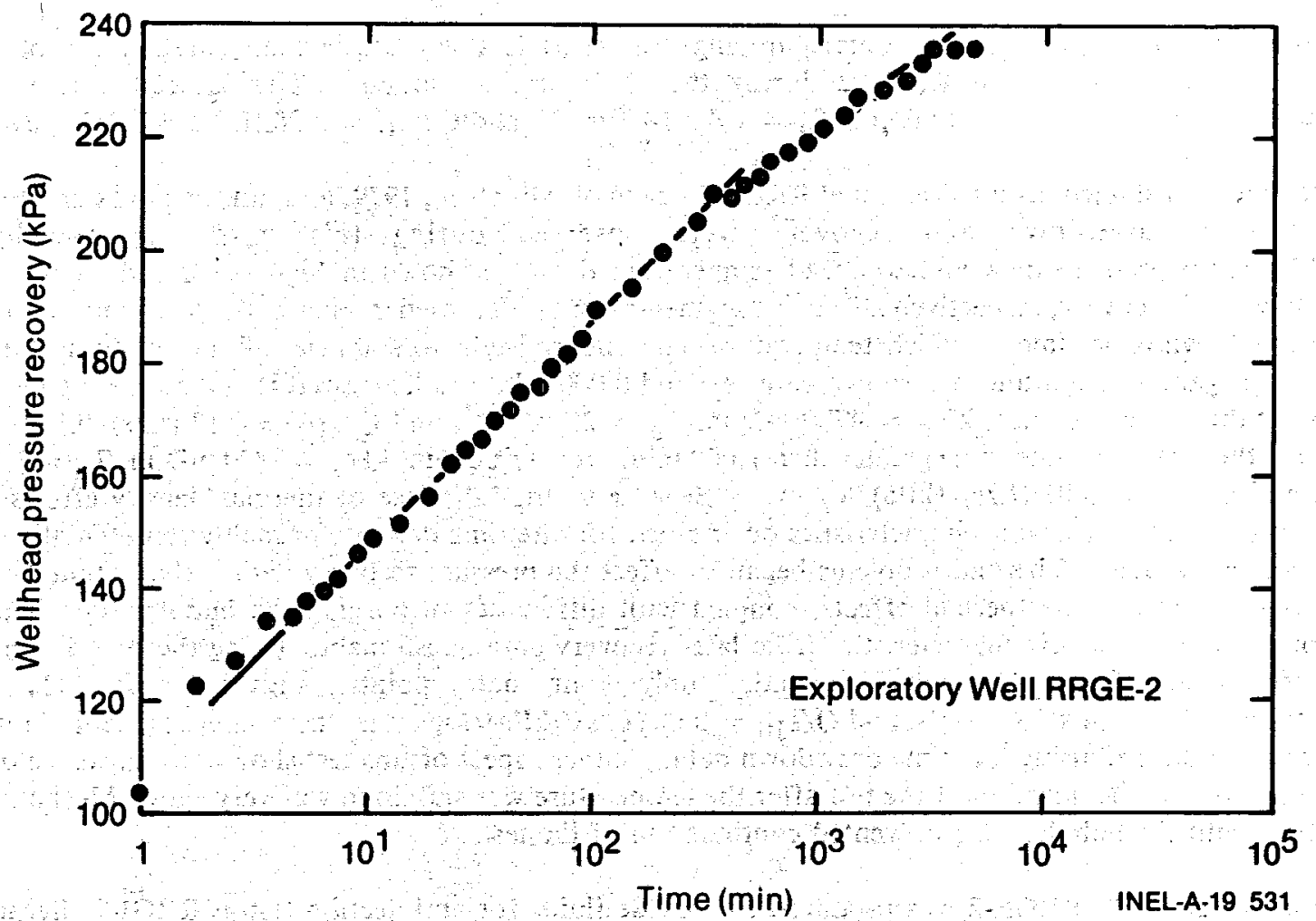

Figure 29. Recovery from pulse testing of well RRGE-2, February 18, 1977 at a discharge rate of $12.6 \mathrm{~L} / \mathrm{s}$ for $24 \mathrm{hours}$. (For recovery tests, time is measured starting from the time of pump shut-in).

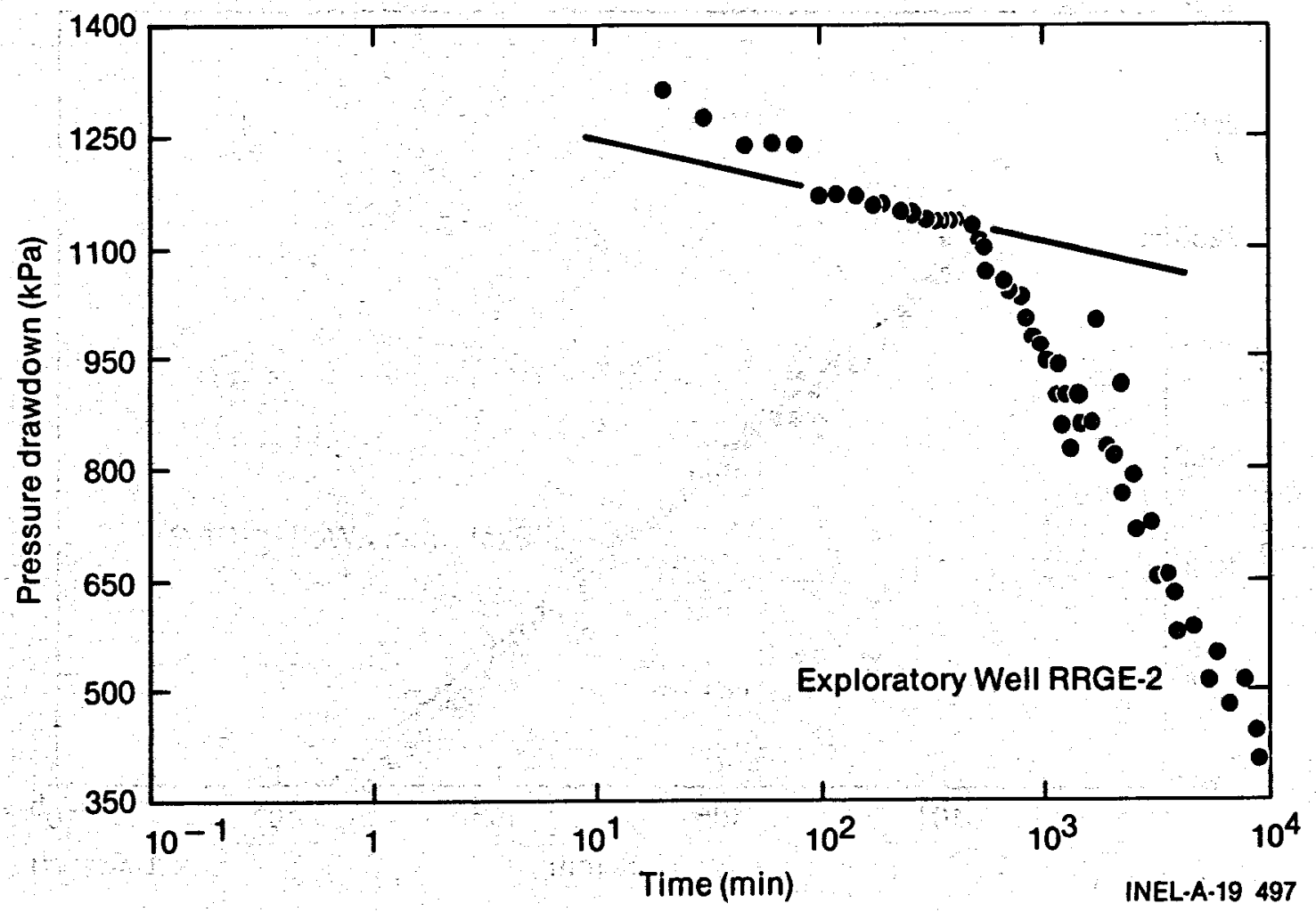

Figure 30. Drawdown during production test of well RRGE-2, May 30, 1978 at a discharge rate of $46.7 \mathrm{~L} / \mathrm{s}$ for 200 continuous hours. 
pressure for three weeks prior to actual pumping. Figure 31 is a semi-logarithmic presentation of the pressure change observed in RRGE-2 during the 72 hours of pumping. The associated reservoir characteristics are: $\mathrm{kH}_{\mathrm{a}}=3200 \mathrm{mD} \cdot \mathrm{m}, \mathrm{T}_{\mathrm{a}}=1.4 \times 10^{-4} \mathrm{~m}^{2} / \mathrm{s}$, and $\mathrm{Q} / \mathrm{s}_{10}=0.08(\mathrm{~L} / \mathrm{s}) /(\mathrm{kPa}) / \log$ cycle.

The longest sustained production test at RRGE-2 began on March 20, 1979, and ran for 504 hours. Both the pressure drawdown and recovery were observed during this test. The downhole (bubbler tube) pressure data and wellhead temperature data are shown in Figures 32 and 33 for the drawdown and recovery, respectively. Two line segments can be identified in Figure 32; the change in slope corresponds with the time at which temperature data finally begin to stabilize, about 1,000 min after pumping began. The spurious drawdown data, beyond $6,000 \mathrm{~min}$, results from difficulties in purging the bubbler tube. From this test, $\mathrm{kH}_{\mathrm{a}}=4700 \mathrm{mD} . \mathrm{m}, \mathrm{T}_{\mathrm{a}}=2.1 \times 10^{-4}$, and $\mathrm{Q} / \mathrm{s}_{10}=0.12(\mathrm{~L} / \mathrm{s}) /(\mathrm{kPa}) / \mathrm{log}$ cycle for the early-time line (time greater than $1,000 \mathrm{~min}$ ) after $1,000 \mathrm{~min}, \mathrm{kH}_{\mathrm{a}}=2800 \mathrm{mD} \cdot \mathrm{m}, \mathrm{T}_{\mathrm{a}}=1.2 \mathrm{x}$ $10^{-4}$, and $\mathrm{Q} / \mathrm{s}_{10}=0.07(\mathrm{~L} / \mathrm{s}) /(\mathrm{kPa}) / \log$ cycle. Because of the influence of thermal/density effects on early-time data, the reservoir characteristics determined for late-time data are probably representative of the reservoir resource. Thermal problems began to affect the pressure recovery data early, within 4 min after pump shut-in. The thermal effects, coupled with difficulties in purging the bubbler tube, make interpretation of reservoir characteristics from later recovery data questionable. Using the first 4 min of recovery data, Figure 33, which includes only four data points, suggests that $\mathbf{k H}_{\mathrm{a}}=$ $3300 \mathrm{mD} . \mathrm{m}, \mathrm{T}_{\mathrm{a}}=1.4 \times 10^{-4} \mathrm{~m}^{2} / \mathrm{s}$, and $\mathrm{Q} / \mathrm{s}_{10}=0.08(\mathrm{~L} / \mathrm{s}) /(\mathrm{kPa}) / \log$ cycle; these values agree favorably with results obtained using late-time drawdown data. Neither aspect of this test shows any existence of a barrier; however, the duration of the test after the temperature was stabilized was very short. Mechanical problems with the bubbler tube prevented continuation of the test.

During August 1979, RRGE-2 was produced to provide fluids for an injection test at RRGI-7. Because primary emphasis of the testing was to evaluate the injection well, operation of and data collection at RRGE-2 was not directed toward analysis of production well pressure data. The production rate was

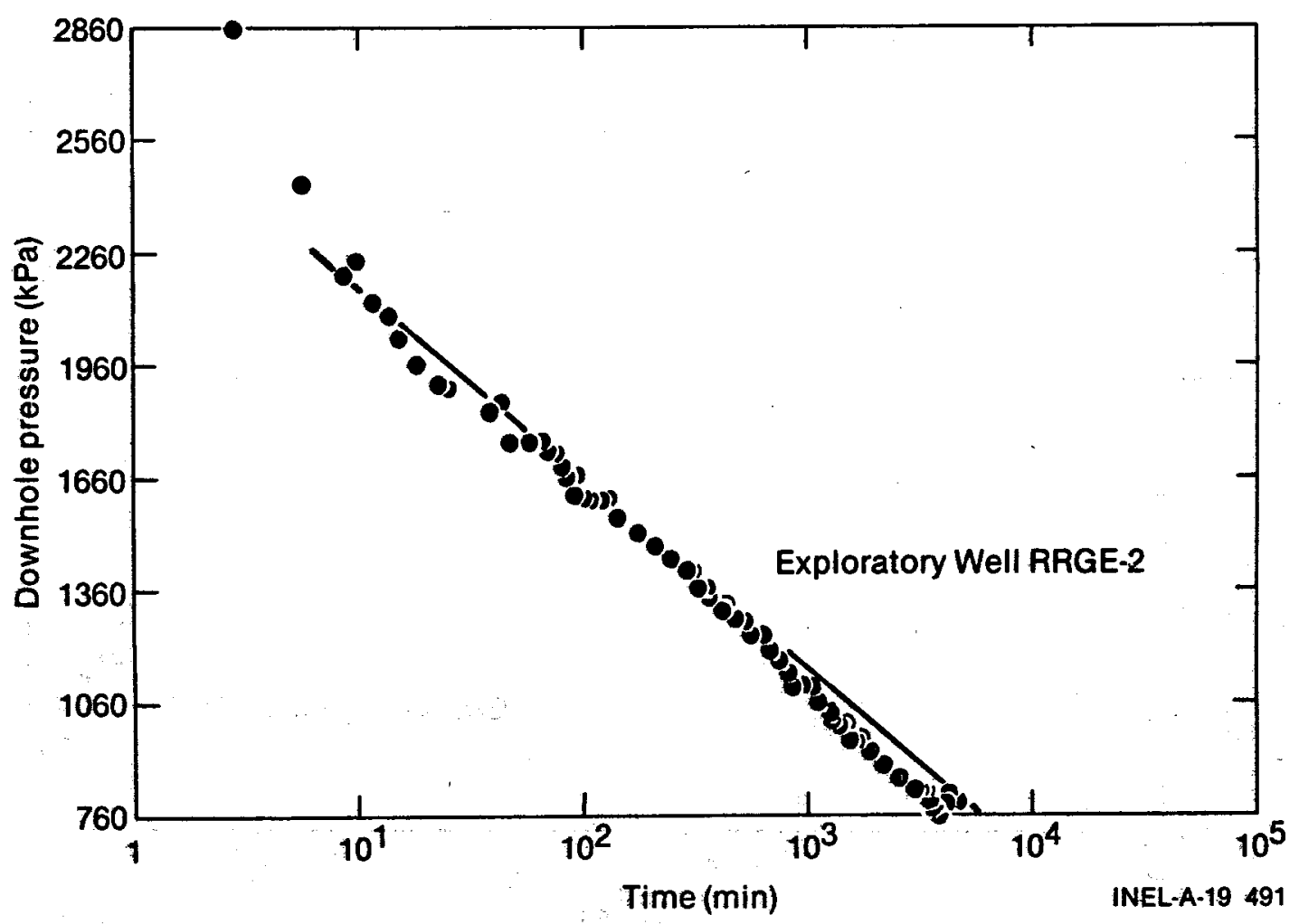

Figure 31. Drawdown during production test of well RRGE-2, January 9, 1979 at a discharge rate of $6.3 \mathrm{~L} / \mathrm{s}$ for 72 continuous hours. 


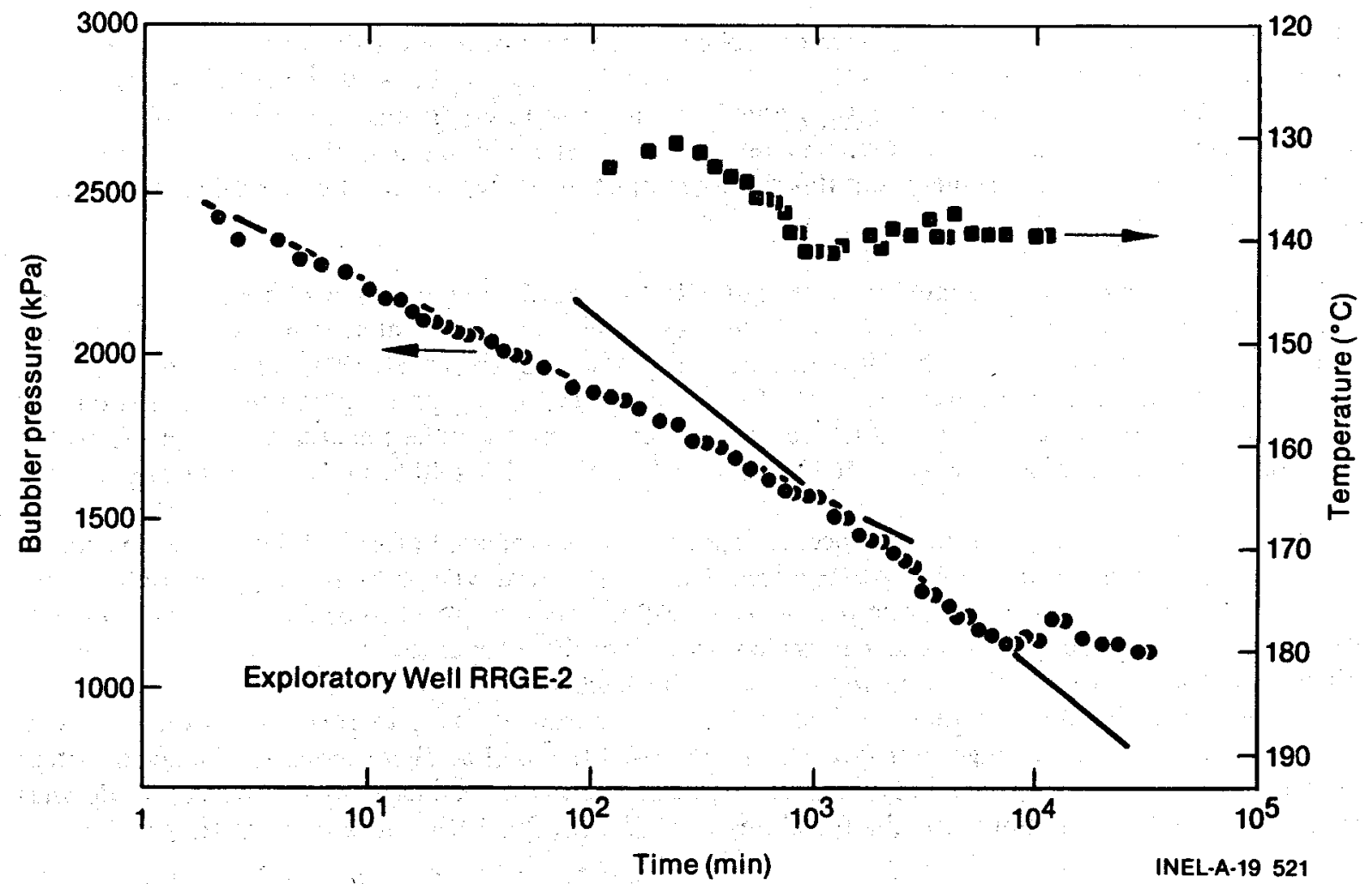

Figure 32. Drawdown during production of well RRGE-2, March 20, 1979 at a discharge rate pf $37.8 \mathrm{~L} / \mathrm{s}$ for $504 \mathrm{hours}$. Data obtained by surface gauge on a continuous bubbler tube. Initial bubbler tube pressure was $3033 \mathrm{kPa}$.

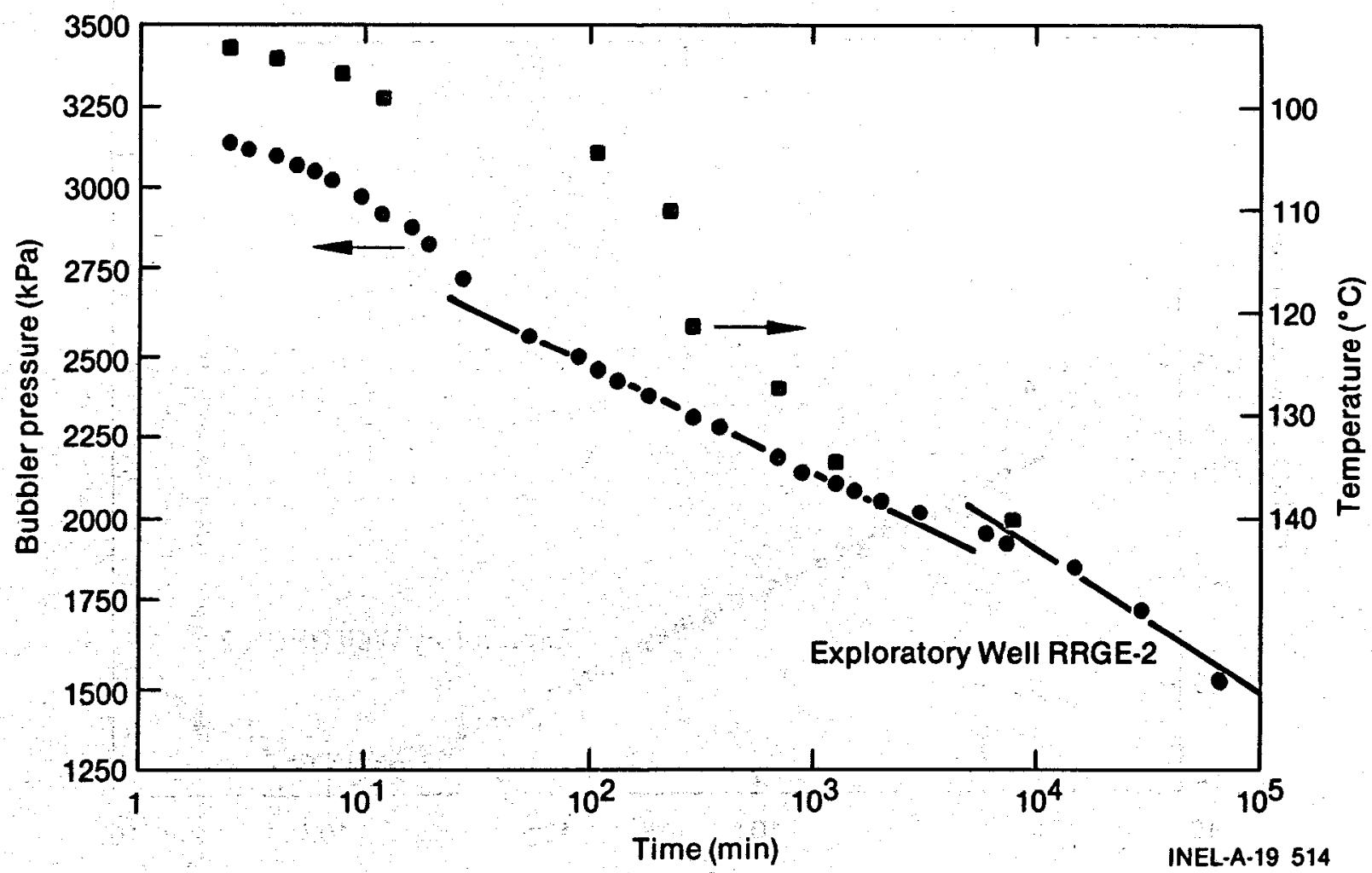

Figure 33. Recovery from production test of well RRGE-2, March 20, 1979 at a discharge rate of $37.8 \mathrm{~L} / \mathrm{s}$ for $504 \mathrm{hours}$. Data obtained by surface gauge on a continuous tube. 
allowed to vary and temperature data were not collected. The plot of pressure drawdown (Figure 34) does show a linear segment from which $\mathrm{kH}_{\mathrm{a}}=11700 \mathrm{mD} \cdot \mathrm{m}, \mathrm{T}_{\mathrm{a}}=5.2 \times 10^{-4} \mathrm{~m}^{2} / \mathrm{s}$, and $\mathrm{Q} / \mathrm{s}_{10}=$ $0.31(\mathrm{~L} / \mathrm{s}) /(\mathrm{kPa}) / \log$ cycle; for the reasons noted above, these reservoir characteristics must be viewed with considerable caution. In fact, a cursory review of the reservoir characteristics obtained from other testing at RRGE-2 (Table 19) shows that this test is significantly different and should be discounted when characterizing the reservoir.

Reservoir characteristics estimated from tests at RRGE-2, which are more than 24 hours long, are summarized in Table 19. The September 20, 1975 test was conducted as an interference test and therefore samples a larger portion of the reservoir than other tests. Also, the August 11, 1979 test, which shows very high reservoir characteristics, was of questionable value due to lack of temperature information and variable flow. Neglecting these two tests, reservoir characteristics for the remaining tests group within fairly narrow bounds: $2700<\mathrm{kH}_{\mathrm{a}}<5600,1.2 \times 10^{-4}<\mathrm{T}_{\mathrm{a}}<2.5 \times 10^{-4}$, and $0.07<\mathrm{Q} / \mathrm{s}_{10}<0.9$.

Table 19 contains a list of apparent specific capacity values evaluated after 24 hours of testing for all production well tests except the August 1979 test. The initial pressure $(3033 \mathrm{kPa})$ were given only for the March 1979 test. Data collected during the January 1979 test were assumed to be free of thermal/density effects because of the long pretest warmup period. In each of the other cases, the static pressure was determined by extending the late-time pressure drawdown line backward in time to one minute. Calculating the static pressure in this manner allows estimation of specific capacity as if thermal effects did not exist. Values of specific capacity range from $0.01(\mathrm{~L} / \mathrm{s}) / \mathrm{kPa}$ to $0.1(\mathrm{~L} / \mathrm{s}) / \mathrm{kPa}$. There appears to be no consistent pattern between specific capacity and discharge. Figure 35 shows the productivity curve when drawdown is determined as discussed above. Results for all tests except May 30, 1979, fall around a straight line.

The interval open to production in RRGE-2 is 1288 to $1994 \mathrm{~m}$. Hole diameter is approximately $21 \mathrm{~cm}$. No significant loss of drilling fluid from the borehole was noted in the interval open to production.

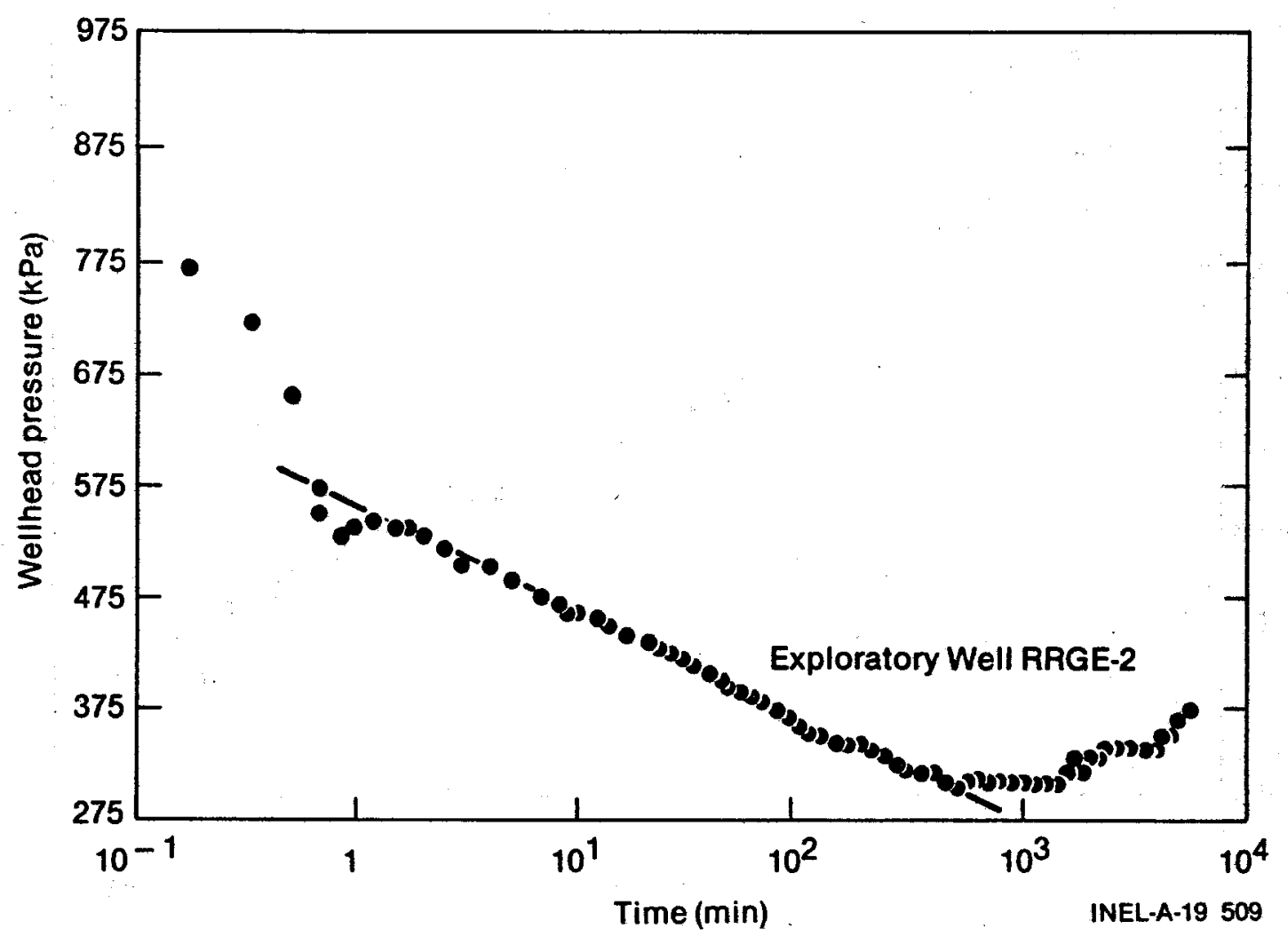

Figure 34. Drawdown during production of well RRGE-2, August 11, 1979 at a discharge rate of $28.41 \mathrm{~L} / \mathrm{s}$ for 92 hours. Data obtained by surface gauge on the wellhead annulus. 
Table 19. Summary of well parameters at RRGE-2

\begin{tabular}{|c|c|c|c|c|c|c|}
\hline Date & $\begin{array}{l}\text { Rate } \\
(\mathrm{L} / \mathrm{s})\end{array}$ & $\begin{array}{c}Q / \mathrm{s} \\
10 \\
{[(\mathrm{~L} / \mathrm{s}) /(\mathrm{kPa}) / \log \text { cycle }]}\end{array}$ & $\begin{array}{c}\mathrm{kH}_{\mathrm{a}} \\
\left(\mathrm{mD}^{\circ} \mathrm{m}\right) \\
\end{array}$ & $\begin{array}{c}\mathrm{T} \\
\left(\mathrm{m}^{2} / \mathrm{s}\right) \\
\end{array}$ & $\begin{array}{r}\mathrm{Q} / \mathrm{s} / 24 \\
(\mathrm{~L} / \mathrm{s}) / \mathrm{kPa} \\
\end{array}$ & Test \\
\hline $09 / 20 / 75$ & 25.2 & $\begin{array}{l}1.02 \\
1.9\end{array}$ & $\begin{array}{l}34000 \\
64000\end{array}$ & $\begin{array}{l}3.0 \times 10^{-4} \\
3.2 \times 10^{-4}\end{array}$ & $--a$ & Interference \\
\hline $02 / 17 / 77$ & 16.6 & 0.15 & 5600 & $2.5 \times 10^{-4}$ & $0.06^{b}$ & Drawdown \\
\hline $02 / 18 / 77$ & - & 0.07 & 2700 & $1.2 \times 10^{-4}$ & - & Recovery \\
\hline $02 / 21 / 77$ & 18.9 & 0.12 & 4600 . & $2.0 \times 10^{-4}$ & $0.04^{\mathrm{b}}$ & Drawdown \\
\hline $03 / 03 / 77$ & 15.8 & 0.13 & 4900 & $2.2 \times 10^{-4}$ & $0.04^{b}$ & Drawdown \\
\hline $03 / 08 / 77$ & 22.0 & 0.11 & 4300 & $1.9 \times 10^{-4}$ & $0.03^{b}$ & Drawdown \\
\hline $05 / 30 / 78$ & 46.7 & $\begin{array}{l}0.75^{c} \\
0.9^{d}\end{array}$ & $\begin{array}{l}2900^{\mathrm{c}} \\
3500^{\mathrm{d}}\end{array}$ & $\begin{array}{l}1.3 \times 10^{-4^{c}} \\
1.6 \times 10^{-4^{d}}\end{array}$ & $0.10^{b}$ & $\begin{array}{l}\text { Drawdown } \\
\text { Drawdown }\end{array}$ \\
\hline $01 / 09 / 79$ & 44.1 & 0.08 & 3200 & $1.4 \times 10^{-4}$ & 0.02 & Drawdown \\
\hline $03 / 20 / 79$ & 37.8 & $\begin{array}{l}0.12^{d} \\
0.07^{d}\end{array}$ & $\begin{array}{l}4700^{\mathrm{c}} \\
2800^{\mathrm{d}}\end{array}$ & $\begin{array}{l}2.1 \times 10^{-4^{c}} \\
1.2 \times 10^{-4^{d}}\end{array}$ & 0.03 & $\begin{array}{l}\text { Drawdown } \\
\text { Drawdown }\end{array}$ \\
\hline $\begin{array}{l}04 / 09 / 79 \\
08 / 11 / 79\end{array}$ & 28.4 & $\begin{array}{l}0.08 \\
0.31\end{array}$ & $\begin{array}{r}3300 \\
11700\end{array}$ & $\begin{array}{l}1.4 \times 10^{-4} \\
5.2 \times 10^{-4}\end{array}$ & & $\begin{array}{l}\text { Recovery } \\
\text { Drawdown }\end{array}$ \\
\hline $\begin{array}{l}\text { a. Data } \\
\text { b. Wellh } \\
\text { c. Early } \\
\text { d. Late- }\end{array}$ & $\begin{array}{l}\text { lected } \\
\text { press } \\
\text { me dat } \\
\text { e data }\end{array}$ & $\begin{array}{l}\text { observation well. } \\
\text { data corrected for ther } \\
\text { ed. }\end{array}$ & effects. & & & \\
\hline
\end{tabular}




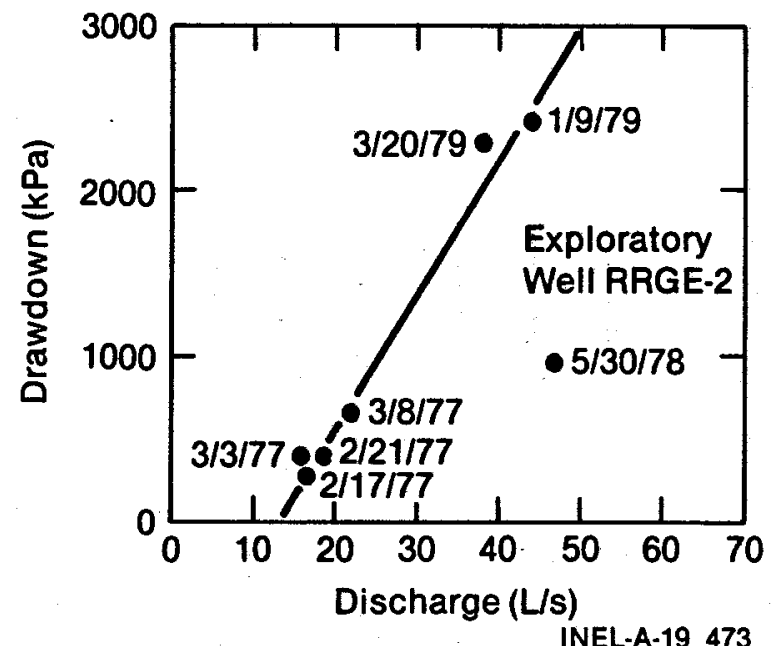

Figure 35. Productivity curve of 24-hour data from exploratory well RRGE-2.

Temperature logs identify three major producing intervals at depths of approximately 1370,1600 , and $1830 \mathrm{~m}$. These zones are apparent as abrupt increases in gradient, evident after cold water has been injected into the well. Caliper logs indicate hole enlargement in the interval 1603 to $1612 \mathrm{~m}$. No flow meter survey information is available. Available USGS televiewer logs indicate possible fractures in the interval 1830 to $1840 \mathrm{~m}$.

The major producing zones in RRGE-2 occur at depths of approximately 1370,1600 , and $1830 \mathrm{~m}$ in the open borehole. The uppermost zone occurs in a sandstone unit of the Tertiary Valley fill; the lower two zones occur in crystalline basement rocks. Section 3, Figure 13 summarizes available information.

The probable maximum sustained free-flowing artesian capability of well RRGE-2 is $22 \mathrm{~L} / \mathrm{s}$. Predicted drawdowns at a range of flow rates and times are shown on Figure 36. The predictions are based on several assumptions:

1. The intended use will be $85 \%$ for a period of three to five years.

2. The estimated hot wellhead shut-in pressure is $970 \mathrm{kPa}$.

3. The minimum wellhead pressure required to sustain flow is $70 \mathrm{kPa}$.

4. The available drawdown for free flow is $900 \mathrm{kPa}$.

5. No interference drawdowns or buildups are imposed on the well.

With these assumptions, the available drawdown would be exhausted after three years of $85 \%$ sustained use at $22 \mathrm{~L} / \mathrm{s}$. Flowing wellhead temperature is approximately $135^{\circ} \mathrm{C}$.

4.5.3 Well RRGE-3. A list of all well tests run at RRGE-3 are in Table 20. A discussion of all tests $<24$ hours follows.

An artesian flow test was conducted between June 8 and 16, 1976. During the first 60 hours of the test, the discharge rate fluctuated between 9.6 and $7.6 \mathrm{~L} / \mathrm{s}$. For the remaining 133 hours the discharge rate averaged $8.6 \mathrm{~L} / \mathrm{s}$. During this test, a downhole pressure instrument was used to monitor change in wellbore pressure. The time history of pressure change for the early portion of the drawdown test is presented in 


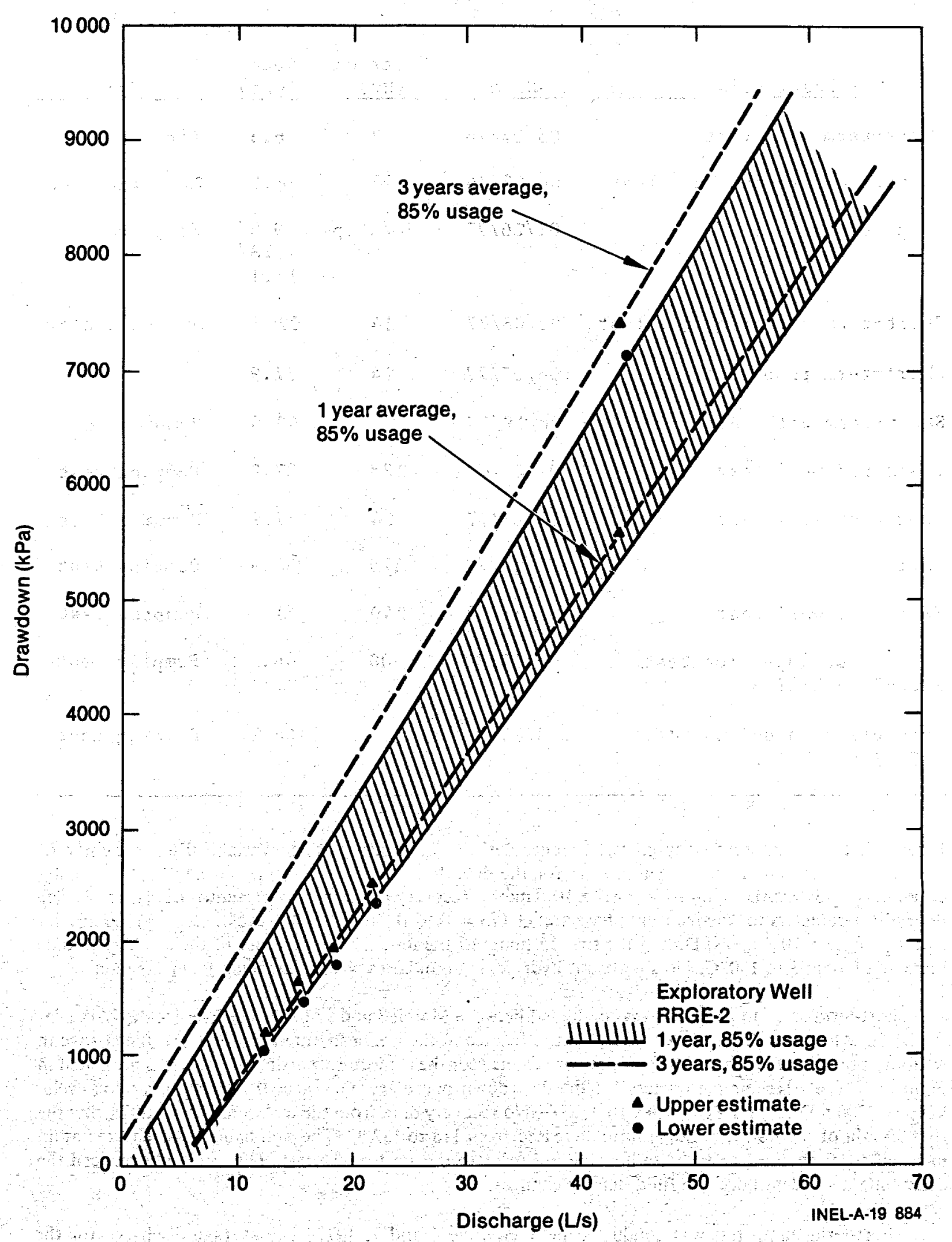

Figure 36. Expected drawdown versus flow rate at exploratory well RRGE-2 (not including interference effects). 


\begin{tabular}{|c|c|c|c|c|}
\hline Description & Date & $\begin{array}{l}\text { Duration } \\
\text { (hr) } \\
\end{array}$ & $\begin{array}{l}\text { Rate } \\
(\mathrm{L} / \mathrm{s}) \\
\end{array}$ & Type \\
\hline Short-term we 11 test & $05 / 04 / 76$ & 7 & 6.3 & Air lift \\
\hline Sustained artesian well test & $06 / 08 / 76$ & 193 & 8.61 & Artesian flow \\
\hline Step test & $01 / 26 / 77$ & $74 /$ step & $\begin{array}{l}9.5 / \\
15.81 \\
22.1\end{array}$ & Step test \\
\hline Short-term artesian well test & $03 / 08 / 77$ & 24 & 22.1 & Artesian flow \\
\hline Short-term pump test & $06 / 07 / 77$ & 24 & 37.9 & \\
\hline Short-term well test & $06 / 29 / 77$ & 24 & 49.6 & Pumping test \\
\hline Sustained well test & $07 / 06 / 77$ & 288 & 37.9 & Pumping test \\
\hline Long-term well test & $11 / 17 / 77$ & $24^{\circ}$ & 37.9 & Pumping test \\
\hline Long-term well test & $11 / 28 / 77$ & 575 & 37.9 & Pumping test \\
\hline Sustained we11 test & $01 / 31 / 78$ & 240 & 41 & Pumping test \\
\hline $\begin{array}{l}\text { Production/injection test: } \\
\text { RRGE-3 to RRGI-6 }\end{array}$ & $05 / 14 / 80$ & 800 & 44.2 & Pumping test \\
\hline $\begin{array}{l}\text { Production/injection test: } \\
\text { RRGE-3 to RRGI-7 }\end{array}$ & $03 / 19 / 81$ & 250 & 44.2 & Pumping test \\
\hline
\end{tabular}

Figure 37. These data were analyzed by Lawrence Berkeley Laboratory using a variable discharge curve-fit computer model. The reservoir parameters for the drawdown phase are: $\mathrm{Q} / \mathrm{s}_{10}=0.1(\mathrm{~L} / \mathrm{s}) /(\mathrm{kPa}) / \log$ cycle, $\mathrm{kH}_{\mathrm{a}}=3700 \mathrm{mD} . \mathrm{m}$, and $\mathrm{T}_{\mathrm{a}}=1.7 \times 10^{-4} \mathrm{~m}^{2} / \mathrm{s}$. Recovery is graphically presented in Figure 38 . The reservoir parameters for the recovery phase are: $\mathrm{Q} / \mathrm{s}_{10}=0.05(\mathrm{~L} / \mathrm{s}) /(\mathrm{kPa}) / \log$ cycle, $\mathrm{kH}_{\mathrm{a}}=1700 \mathrm{mD} . \mathrm{m}$, and $T_{a}=7.8 \times 10^{-5} \mathrm{~m}^{2} / \mathrm{s}$. During the first 15 hours of the test, the temperature of the discharge fluids increased from 93 to $150^{\circ} \mathrm{C}$. No significant hydrologic boundaries were interpreted from the data.

A short-term artesian flow test was conducted between March 8 and 9, 1977. The average discharge for the 24-hour test was $22.1 \mathrm{~L} / \mathrm{s}$. A pressure gauge located at the wellhead annulus monitored the change in wellbore pressure. The time history of pressure change for the drawdown portion of the test is presented in Figure 39. The reservoir parameters for the drawdown phase are: $Q / s_{10}=0.1(\mathrm{~L} / \mathrm{s}) /(\mathrm{kPa}) / \log$ cycle, $\mathrm{kH}_{\mathrm{a}}=4200 \mathrm{mD} . \mathrm{m}$, and $\mathrm{T}_{\mathrm{a}}=1.9 \times 10^{-4} \mathrm{~m}^{2} / \mathrm{s}$. No recovery data from the test were obtained. During the first $80 \mathrm{~min}$ of the test, the temperature increased from 118 to $132^{\circ} \mathrm{C}$. The well had been preheated at an unspecified discharge rate for a 24-hour period prior to the start of the test. This probably reduced the early time-dependent borehole fluid density changes.

A short-term pump test was conducted between June 6 and 7, 1977. The average discharge for the 24-hour test was $37.9 \mathrm{~L} / \mathrm{s}$. The annulus drawdown was measured using a bubbler tube set above the pump at $236 \mathrm{~m}$. The initial (cold) wellhead pressure was $469 \mathrm{kPa}$. The maximum drawdown for the test was 


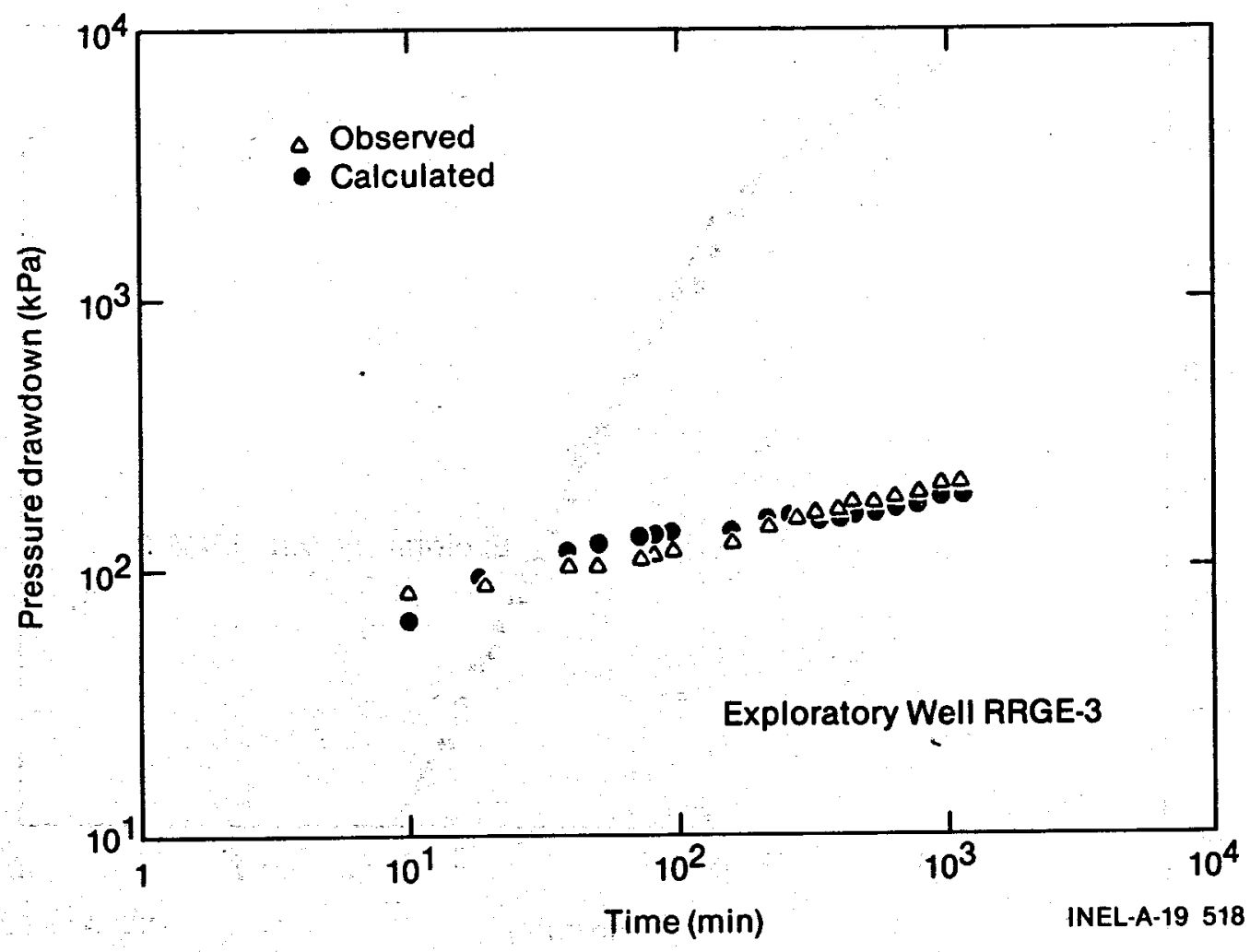

Figure 37. Drawdown during production test of well RRGE-3 June 8, 1976 at an average discharge rate of $8.6 \mathrm{~L} / \mathrm{s}$ for 193 hours (analyzed by Lawrence Berkeley Laboratory).

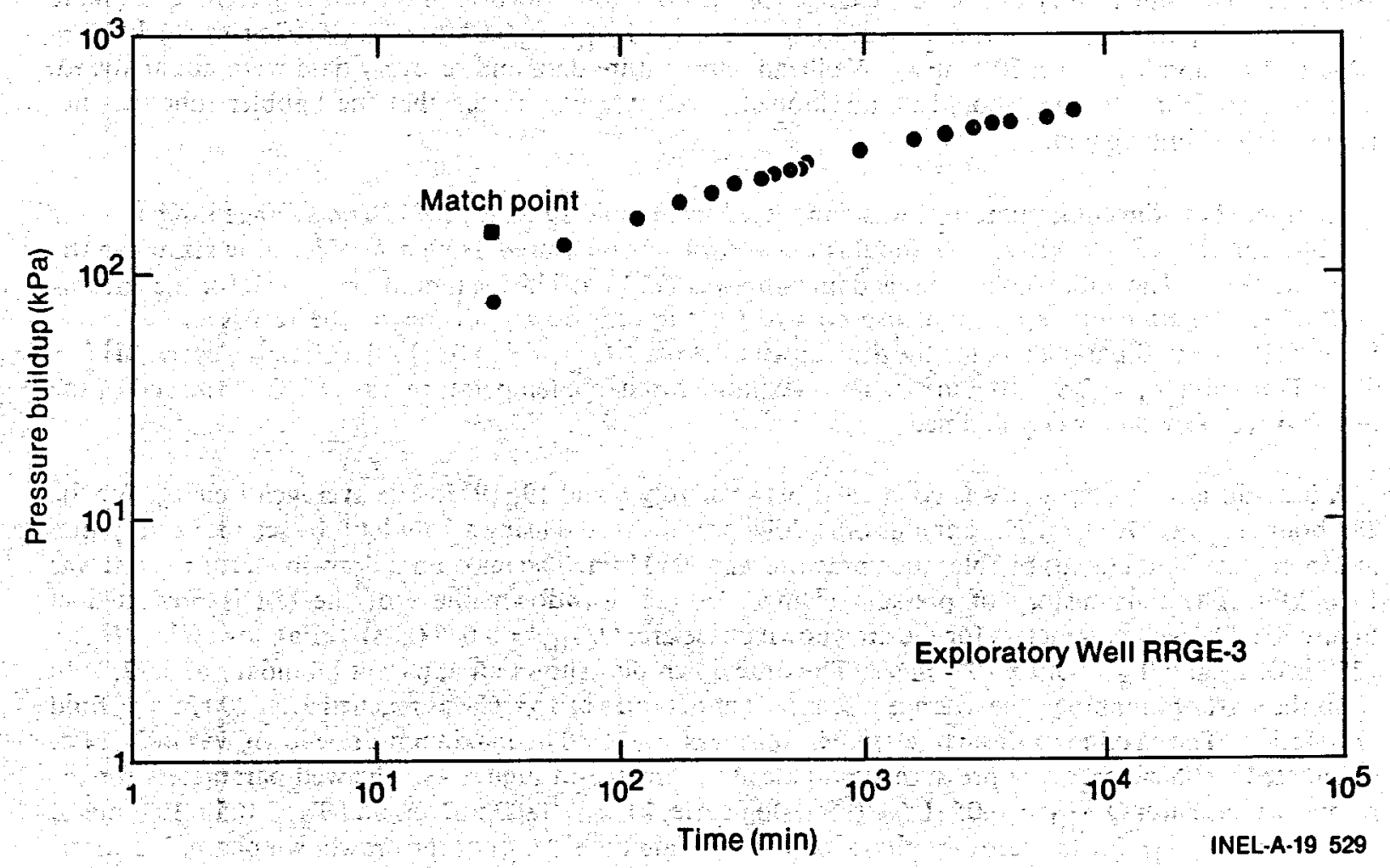

Figure 38. Recovery from production test of well RRGE-3, June 8, 1976 at an average discharge rate of $8.6 \mathrm{~L} / \mathrm{s}$ for 193 hours. 


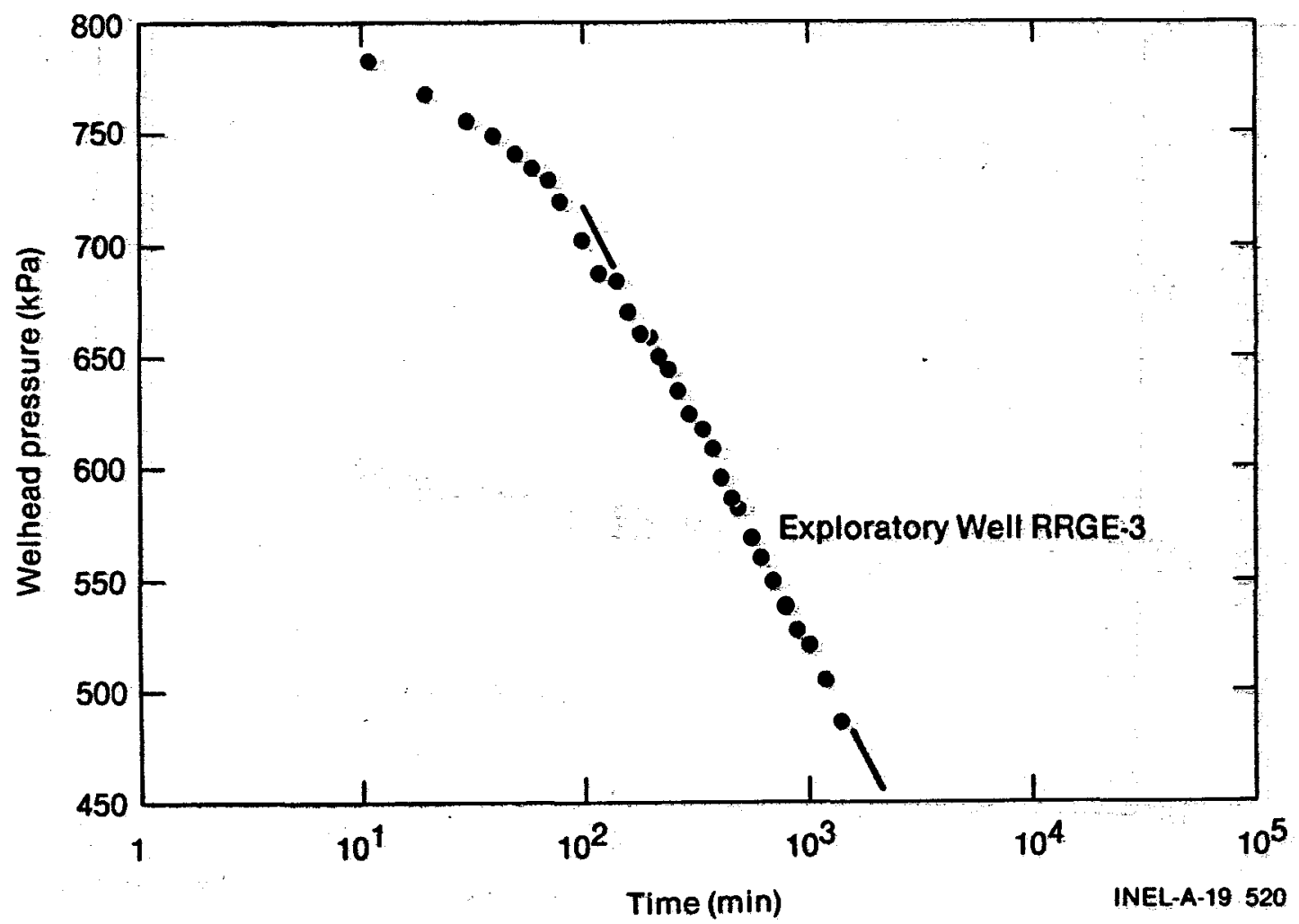

Figure 39. Drawdown during production test of well RRGE-3, March 8, 1977 at an average discharge rate of $22.1 \mathrm{~L} / \mathrm{s} \mathrm{for}$ 24 hours.

$1418 \mathrm{kPa}$. The time history of pressure change for the drawdown portion of the test is presented in Figure 40. The well parameters for the drawdown phase are: $Q / s_{10}=0.03(\mathrm{~L} / \mathrm{s}) /(\mathrm{kPa}) / \log$ cycle, $\mathbf{k H}_{\mathrm{a}}=$ $2200 \mathrm{mD} . \mathrm{m}$, and $\mathrm{T}_{\mathrm{a}}=1 \times 10^{-4} \mathrm{~m}^{2} / \mathrm{s}$. Wellhead temperature data and recovery data were not analyzed. The analysis from this test should be questioned, since it was reported that the bubbler tube was not responding as anticipated.

Another short-duration pump test was conducted from June 29 to 30,1977 . The average discharge for the 24-hour test was $49.6 \mathrm{~L} / \mathrm{s}$. The annulus drawdown was measured using a bubbler tube set above the pump at $236 \mathrm{~m}$. The initial (cold) wellhead pressure was $773 \mathrm{kPa}$. The maximum drawdown for the test was $2173 \mathrm{kPa}$. The time history of pressure change for the drawdown portion of the test is presented in Figure 41. The well parameters for the drawdown phase are: $\mathrm{Q} / \mathrm{s}_{10}=0.02(\mathrm{~L} / \mathrm{s}) /(\mathrm{kPa}) / \log$ cycle, $\mathrm{kH}_{\mathrm{a}}=$ $600 \mathrm{mD} . \mathrm{m}$, and $\mathrm{T}_{\mathrm{a}}=2.9 \times 10^{-5} \mathrm{~m}^{2} / \mathrm{s}$. The maximum discharge temperature was $148^{\circ} \mathrm{C}$ at the end of the test. No recovery data were obtained.

A long-duration pump test was conducted between July 6 and 19, 1977. The average discharge for the 288-hour test was $37.9 \mathrm{~L} / \mathrm{s}$. The annulus drawdown was measured using a bubbler tube set above the pump at $236 \mathrm{~m}$. The initial (cold) bubbler tube pressure was $2930 \mathrm{kPa}$. The maximum drawdown for the test was $1310 \mathrm{kPa}$. The time history of pressure change for the drawdown phase of the test is presented in Figure 42. The well parameters for the drawdown phase are: $\mathrm{Q} / \mathrm{s}_{10}=0.048(\mathrm{~L} / \mathrm{s}) /(\mathrm{kPa}) / \log$ cycle, $\mathrm{kH}_{\mathrm{a}}=$ $1250 \mathrm{mD} . \mathrm{m}$, and $\mathrm{T}_{\mathrm{a}}=5.9 \times 10^{-5} \mathrm{~m}^{2} / \mathrm{s}$. The drawdown plot shows an apparent boundary at $3,325 \mathrm{~min}$ from the start of pumping. The average discharge temperature of $143^{\circ} \mathrm{C}$ was reached after 200 min of fluid production. The maximum discharge temperature was $148^{\circ} \mathrm{C}$. The maximum drawdown was $4826 \mathrm{kPa}$. Calculated wellhead recovery pressure is graphically presented in Figure 43. The well parameters for the recovery phase are: $\mathrm{Q} / \mathrm{s}_{10}=0.05(\mathrm{~L} / \mathrm{s}) /(\mathrm{kPa}) / \log$ cycle, $\mathrm{kH}_{\mathrm{a}}=1800 \mathrm{mD} \cdot \mathrm{m}$, and $\mathrm{T}_{\mathrm{a}}=8.5 \times 10^{-5} \mathrm{~m}^{2} / \mathrm{s}$. The value of $Q / s_{10}$ for the recovery phase matches the late time $Q / s_{10}$ of the drawdown phase. However, the slope $s_{10}=758 \mathrm{kPa} / \mathrm{log}$ cycle of the recovery is for late time data with no consideration for wellbore cooling effects. The close relationship of late-time drawdown to late-time recovery may be coincidental. 


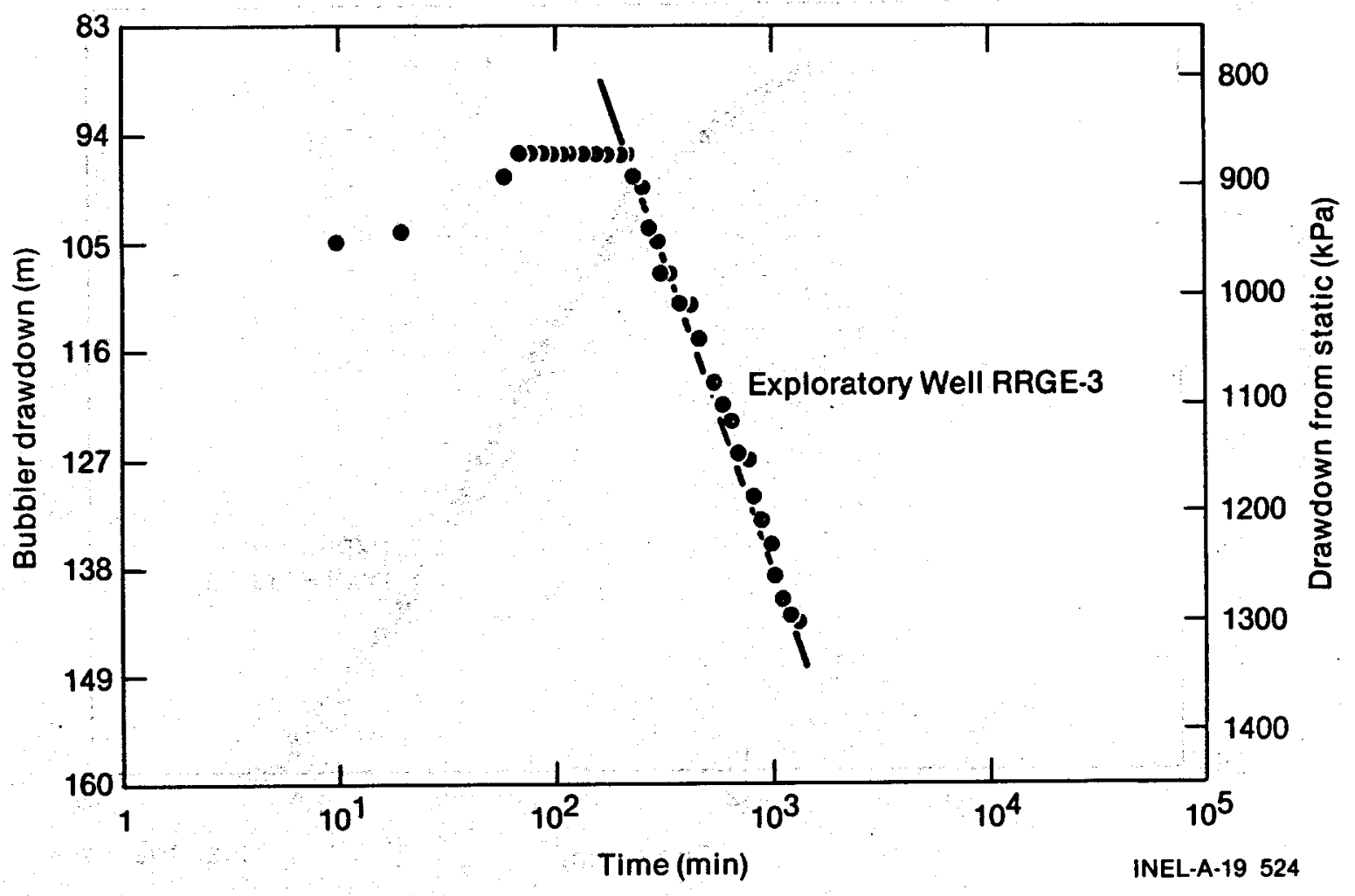

Figure 40. Drawdown during production test of well RRGE-3, June 6, 1977 at a discharge rate of $37.9 \mathrm{~L} / \mathrm{s}$ for 24 hours. Static (cold) water level was $\mathbf{4 7 . 9} \mathrm{m}$ above ground level.

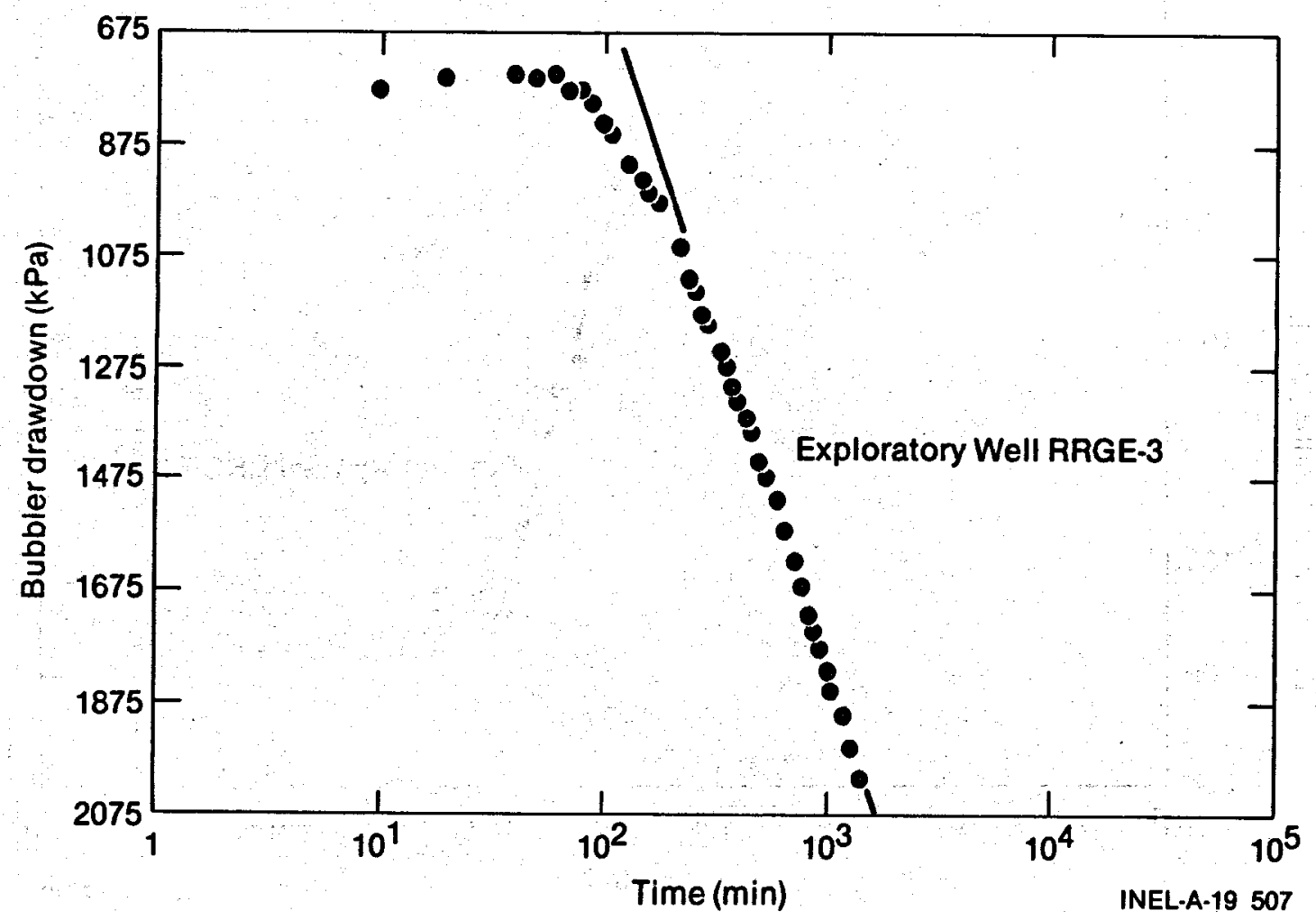

Figure 41. Drawdown during production test of well RRGE-3, June 29, 1977 at a discharge rate of $49.6 \mathrm{~L} / \mathrm{s}$ for $24 \mathrm{hours}$. Static (cold) water level was $78.9 \mathrm{~m}$ above ground level. 


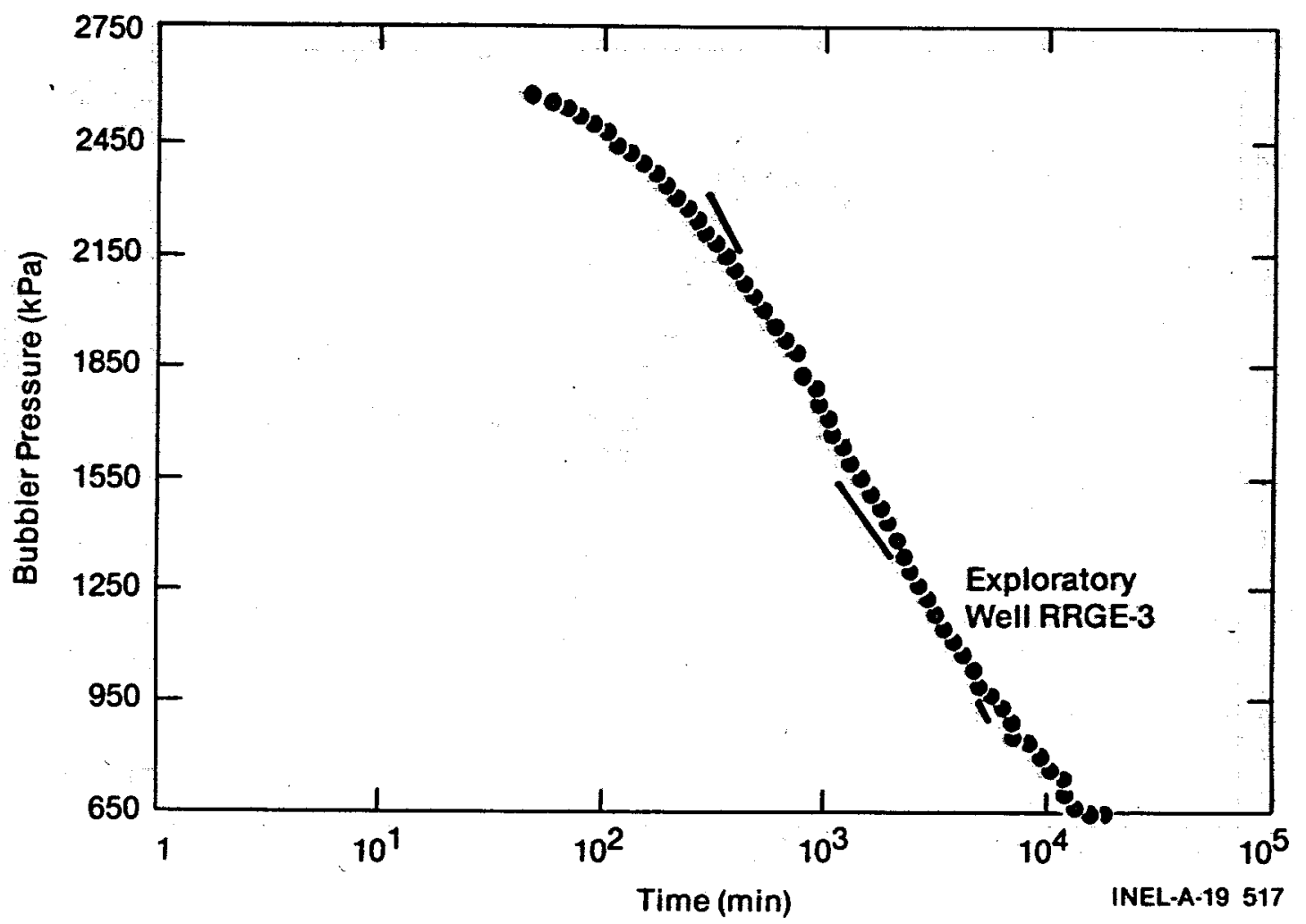

Figure 42. Drawdown during production test of well RRGE-3, July 6, 1977 at a discharge rate of $37.9 \mathrm{~L} / \mathrm{s}$ for 288 hours.

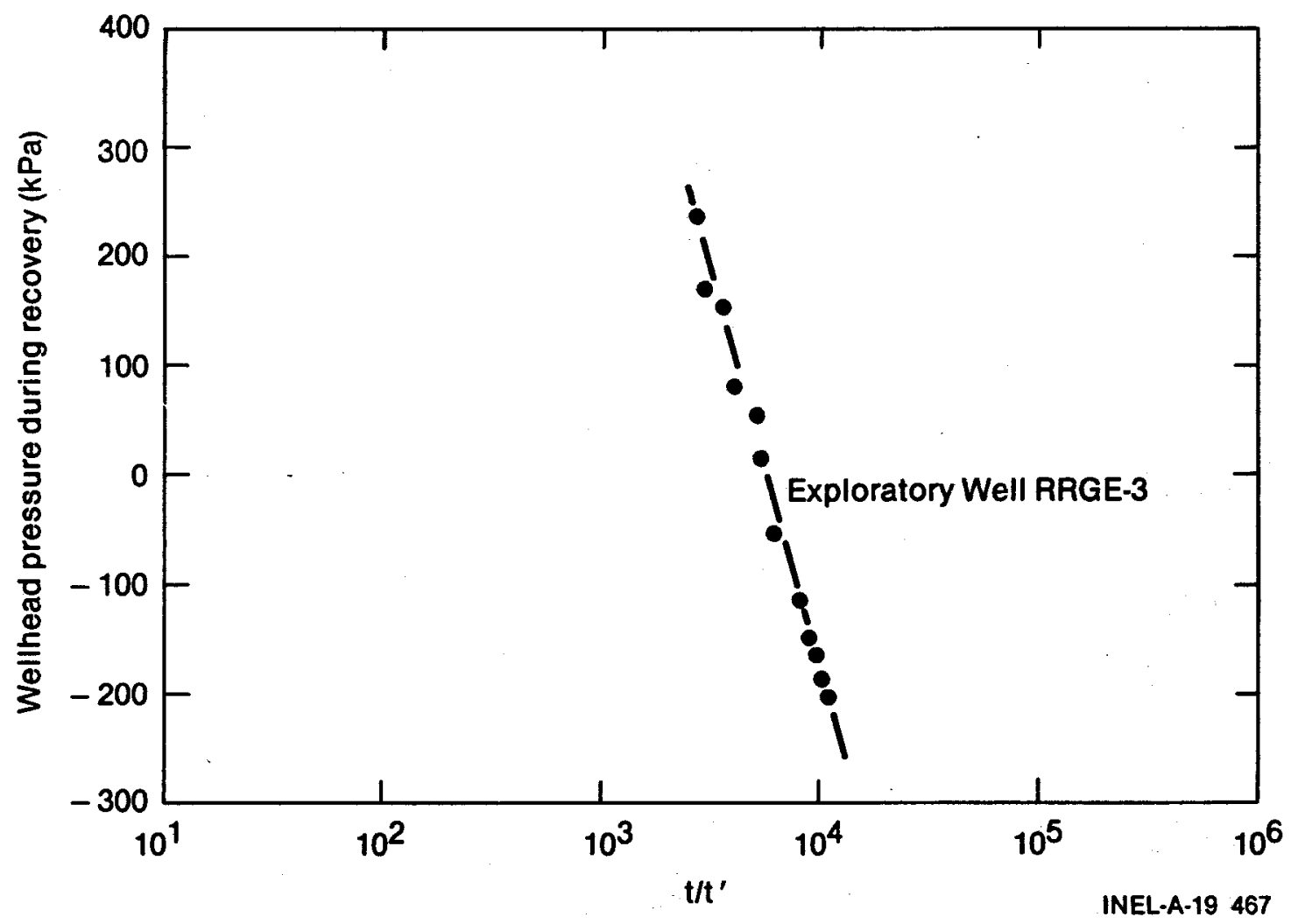

Figure 43. Calculated recovery from production test of well RRGE-3, July 6, 1977 at a discharge rate of $37.9 \mathrm{~L} / \mathrm{s}$ for 288 hours. 
Another short-duration pump test was conducted on November 17 and 18, 1977. The average discharge for the 24-hour test was $37.9 \mathrm{~L} / \mathrm{s}$. The annulus drawdown was measured using a bubbler tube. The time history of pressure change for the drawdown phase of the test is presented in Figure 44. The well parameters for the drawdown phase are: $\mathrm{Q} / \mathrm{s}_{10}=0.04(\mathrm{~L} / \mathrm{s}) /(\mathrm{kPa}) / \log$ cycle, $\mathrm{kH}_{\mathrm{a}}=1600 \mathrm{mD}$. $\mathrm{m}$, and $T_{a}=7.5 \times 10^{-5} \mathrm{~m}^{2} / \mathrm{s}$. No thermal or recovery data were analyzed for this test.

Another long-duration pump test was conducted from November 28 to December 22,1977 . The average discharge for the 575-hour test was $37.9 \mathrm{~L} / \mathrm{s}$. The well had been flowing for seven days prior to the start of the test at unreported low artesian flow rates. The annulus drawdown was measured using a bubbler tube. The initial (warm) bubbler tube pressure was $2875 \mathrm{kPa}$. The time history of pressure change during the drawdown test is presented in Figure 45. The reservoir parameters for the drawdown phase are: $Q / s_{10_{1}}=$ $0.04(\mathrm{~L} / \mathrm{s}) /(\mathrm{kPa}) / \log$ cycle, $\mathrm{Q} / \mathrm{s}_{10_{2}}=0.059(\mathrm{~L} / \mathrm{s}) /(\mathrm{kPa}) / \log$ cycle, $\mathrm{kH}_{\mathrm{a}}=1600 \mathrm{mD} . \mathrm{m}$, and $\mathrm{T}_{\mathrm{a}}=7 \mathrm{x}$ $10^{-5} \mathrm{~m}^{2} / \mathrm{s}$. The drawdown plot shows an apparent boundary at about $8,500 \mathrm{~min}$ from the start of pumping. No discharge temperature was reported. Recovery is graphically presented in Figure 46 . Well parameters calculated for the recovery phase are: $\mathrm{Q} / \mathrm{s}_{10_{1}}=0.04(\mathrm{~L} / \mathrm{s}) /(\mathrm{kPa}) / \log$ cycle, $\mathrm{Q} / \mathrm{s}_{10}=$ $0.07(\mathrm{~L} / \mathrm{s}) /(\mathrm{kPa}) / \log$ cycle, $\mathrm{kH}_{\mathrm{a}}=1600 \mathrm{mD} . \mathrm{m}$, and $\mathrm{T}_{\mathrm{a}}=7 \times 10^{-5} \mathrm{~m}^{2} / \mathrm{s}$. The break of slope in the recovery plot is assumed to be time-dependent density effects. The second break of slope in the recovery plot (at $-6,570 \mathrm{~min}$ from the start of recovery) exhibits unexplained pressure changes. Figure 47 is a graph of the bubbler pressure versus wellhead pressure during recovery. Abrupt changes in the relationship between bubbler pressure and wellhead pressure occur for bubbler pressures greater than $2310 \mathrm{kPa}$. These errors may result because of errors in reading the gauges. The unit slope when the bubbler pressures are between 2068 and $2310 \mathrm{kPa}$ suggest that the bubbler pressure data and the wellhead pressure data are equally valid. The wellhead data for pressure greater than $2344 \mathrm{kPa}$ appear to be approximately $48 \mathrm{kPa}$ too great relative to the trend from 2068 to $2310 \mathrm{kPa}$ (Figure 47). The increased slope of the data for bubbler pressure greater than $2427 \mathrm{kPa}$ is caused by temporally-dependent density differences of the nitrogen gas in the bubbler tube and the water in the wellbore surrounding the bubbler tube.

Another long-duration pump test was conducted from January 31 to February 9, 1978. The average discharge for the 240 -hour test was $41 \mathrm{~L} / \mathrm{s}$. The well had been flowing at an unreported low discharge rate for at least 15 days prior to the start of the test. The annulus drawdown was measured using a bubbler tube. The initial (warm) bubbler tube pressure was $2896 \mathrm{kPa}$. The time history of pressure change during the drawdown test is presented in Figure 48. The well parameters for the drawdown phase are: $Q / s_{10}=$ $0.03(\mathrm{~L} / \mathrm{s}) /(\mathrm{kPa}) / \log$ cycle, $\mathrm{Q} / \mathrm{s}_{102}=0.05(\mathrm{~L} / \mathrm{s}) /(\mathrm{kPa}) / \log$ cycle, $\mathrm{kH}_{\mathrm{a}}=1200 \mathrm{mD} \cdot \mathrm{m}$, and $\mathrm{T}_{\mathrm{a}}=5.8 \mathrm{x}$ $10^{-7} \mathrm{~m}^{2} / \mathrm{s}$. The drawdown plot shows an apparent boundary at $3,400 \mathrm{~min}$ from the start of pumping. Only a spot check of discharge temperature was recorded. No recovery data were recorded.

A long-duration pump test was conducted on May 14, 1980 through June 17, 1980. The average discharge for the 800 -hour test was $44.2 \mathrm{~L} / \mathrm{s}$. No analysis of the test was accomplished.

A final long-duration pump test was conducted from March 19 to 30, 1981. The average discharge for the 250-hour test was $44.2 \mathrm{~L} / \mathrm{s}$. The annulus pressure was measured using a bubbler tube. The initial (warm) bubbler tube pressure was $3309 \mathrm{kPa}$. The time history of pressure change during the drawdown test is presented in Figure 49. The well parameters for the drawdown phase are: $Q / s_{10}=$ $0.079(\mathrm{~L} / \mathrm{s}) /(\mathrm{kPa}) / \log$ cycle, $\mathrm{Q} / \mathrm{s}_{10}=0.04(\mathrm{~L} / \mathrm{s}) /(\mathrm{kPa}) / \log$ cycle, $\mathrm{kH}_{\mathrm{a}}=2900 \mathrm{mD} . \mathrm{m}$, and $\mathrm{T}_{\mathrm{a}}=1.3 \mathrm{x}$ $10^{-4} \mathrm{~m}^{2} / \mathrm{s}$. The drawdown plot shows an apparent boundary at $400 \mathrm{~min}$ from the start of pumping. However, the break in slope coincides with a pump outage and is thus suspect. Numerous other pump outages and a discharge rate change at 13,000 min effects the decline curve after 300 min from the start of the test. No temperatures versus discharge were reported. Recovery is graphically presented in Figure 50. Well parameters calculated for the recovery phase are: $\mathrm{Q} / \mathrm{s}_{10}=0.05(\mathrm{~L} / \mathrm{s}) /(\mathrm{kPa}) / \log$ cycle, $\mathrm{kH}_{\mathrm{a}}=$ $1700 \mathrm{mD} . \mathrm{m}, \mathrm{T}_{\mathrm{a}}=8 \times 10^{-5} \mathrm{~m}^{2} / \mathrm{s}$. However, these data are relatively late-time recovery which should have borehole thermal effects.

A summary of the calculated well parameters for those well tests $>24$ hours duration are presented in Table 21. It appears that the low flow rates produce slightly greater magnitude well parameters. The 


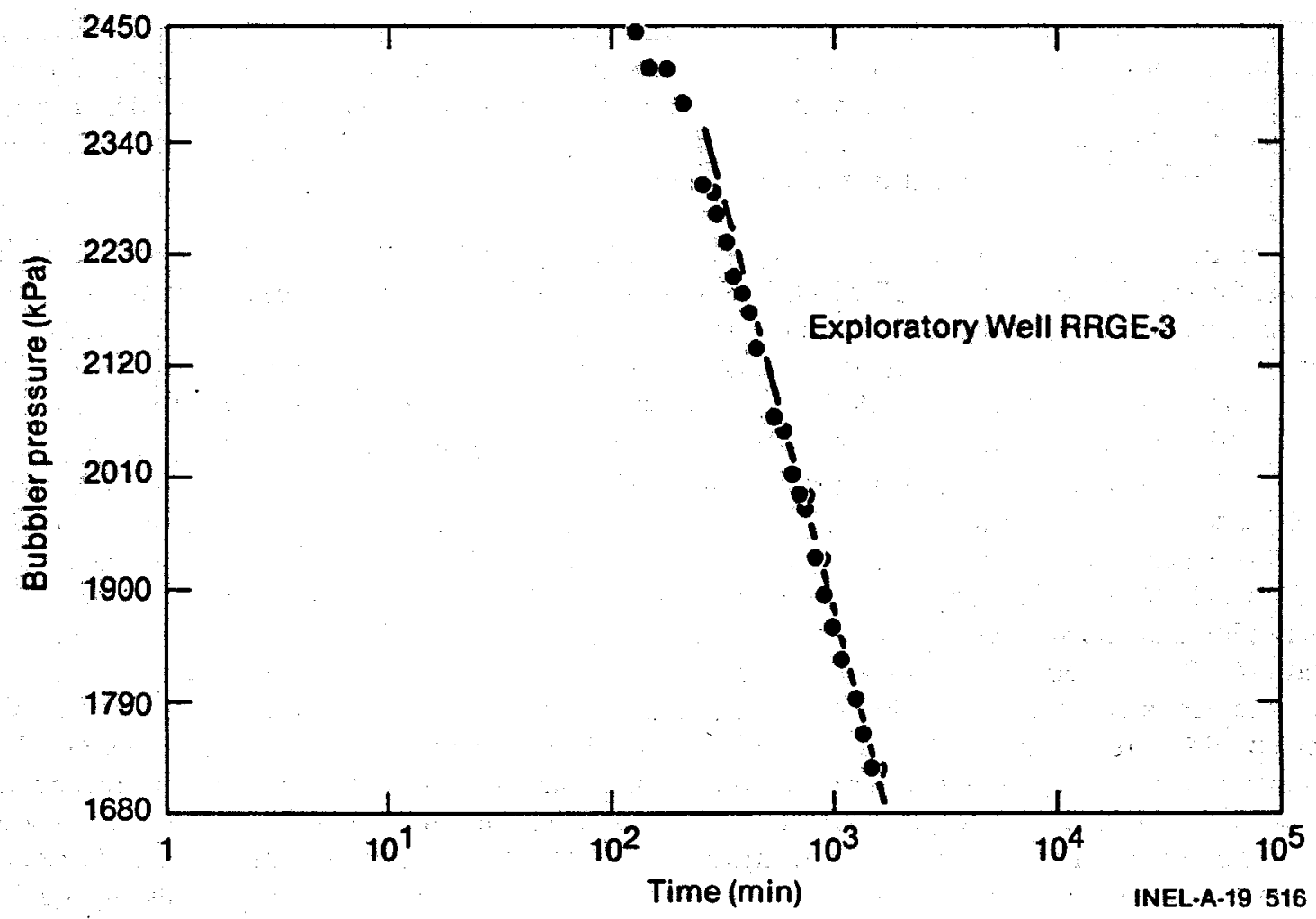

Figure 44. Drawdown during production test of well RRGE-3, November 17, 1977 at a discharge rate of $37.9 \mathrm{~L} / \mathrm{s}$ for 24 hours.

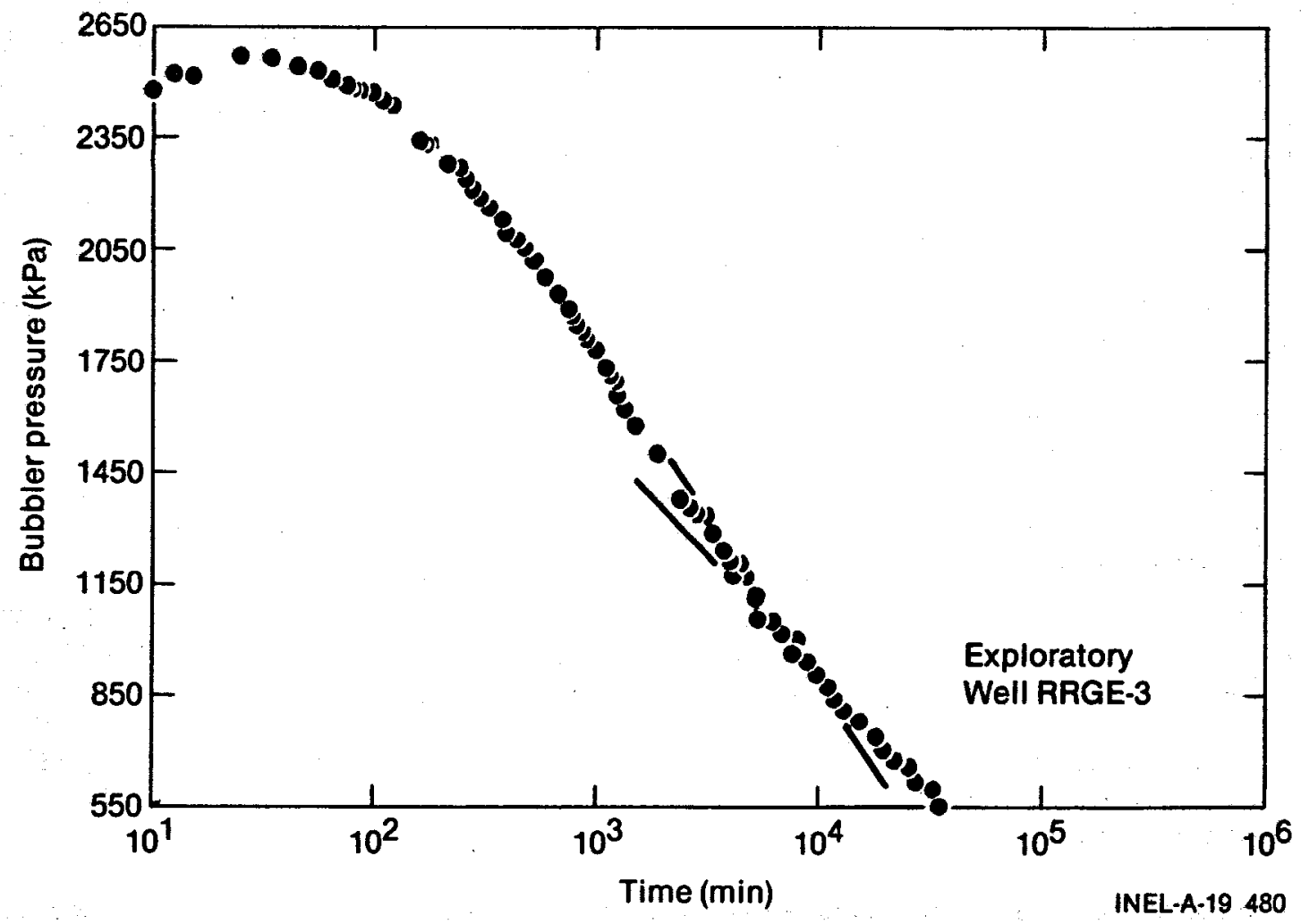

Figure 45. Drawdwon during production test of well RRGE-3, December 22, 1977 at a discharge rate of $37.9 \mathrm{~L} / \mathrm{s}$ for 575 hours. 


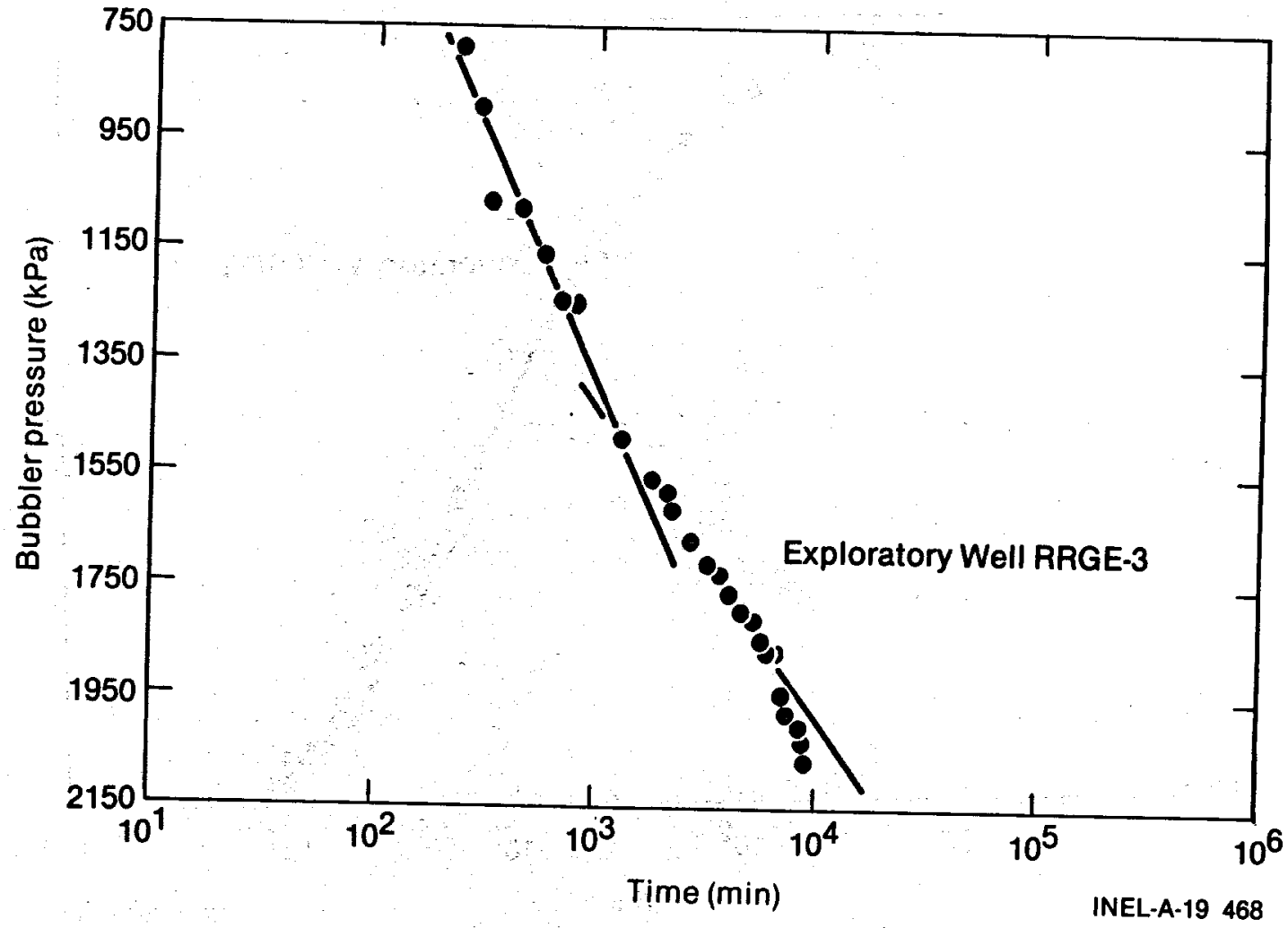

Figure 46. Recovery from production test of well RRGE-3, December 22, 1977 at a discharge rate of $37.9 \mathrm{~L} / \mathrm{s}$ for 575 hours.

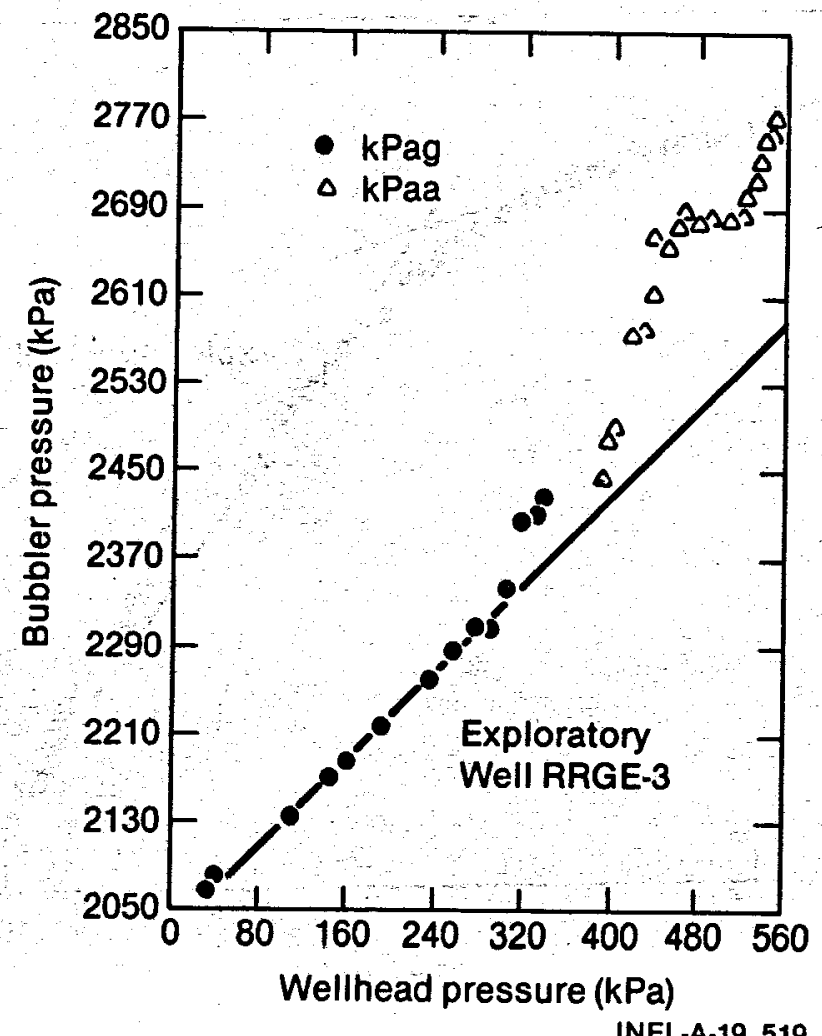

Figure 47. Bubbler pressure versus wellhead pressure for recovery of the production test of well RRGE-3, December 22, 1977. 


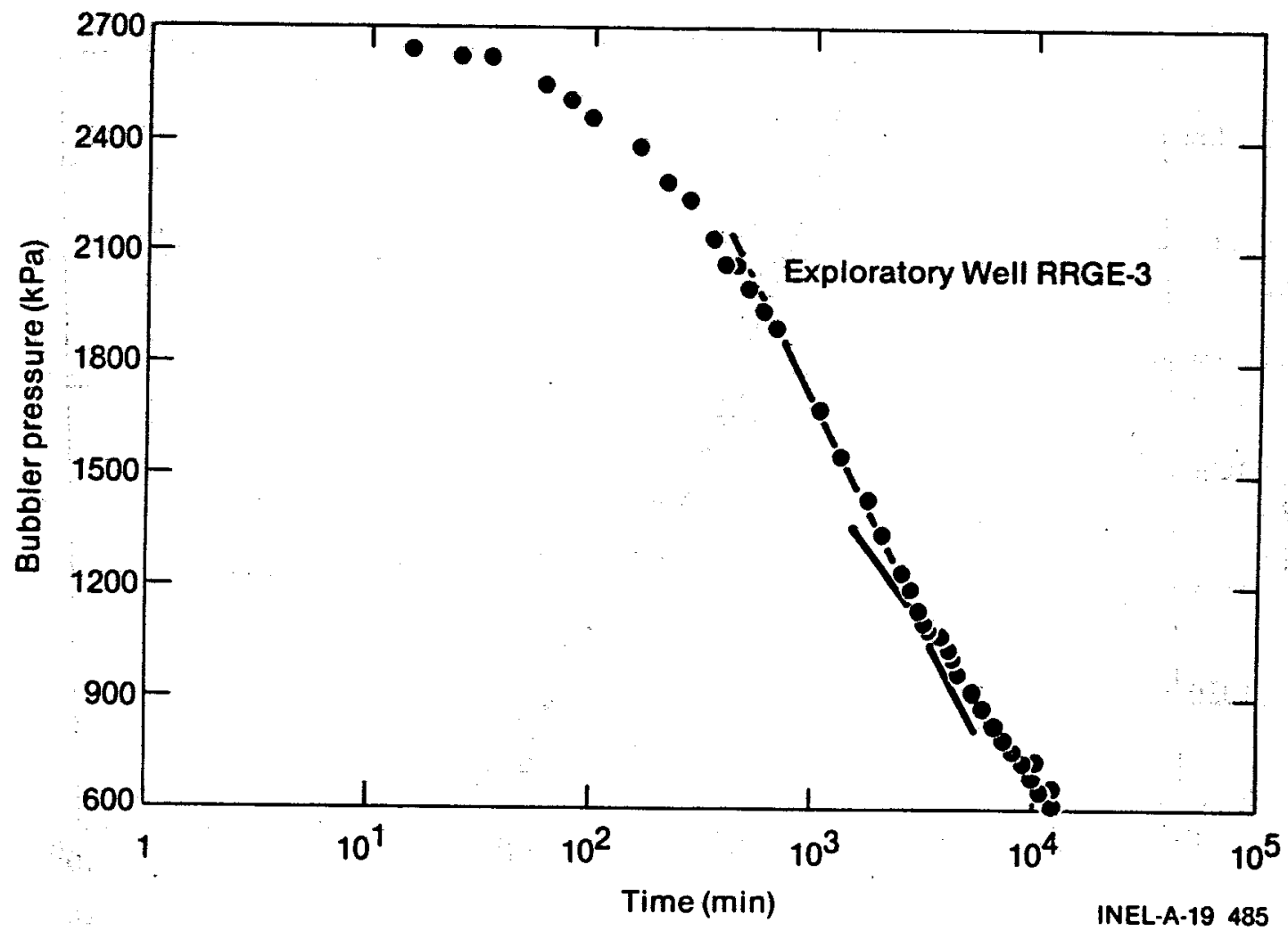

Figure 48. Drawdown during production test of well RRGE-3, January 31,1978 at a discharge rate of $41 \mathrm{~L} / \mathrm{s}$ for 240 hours.

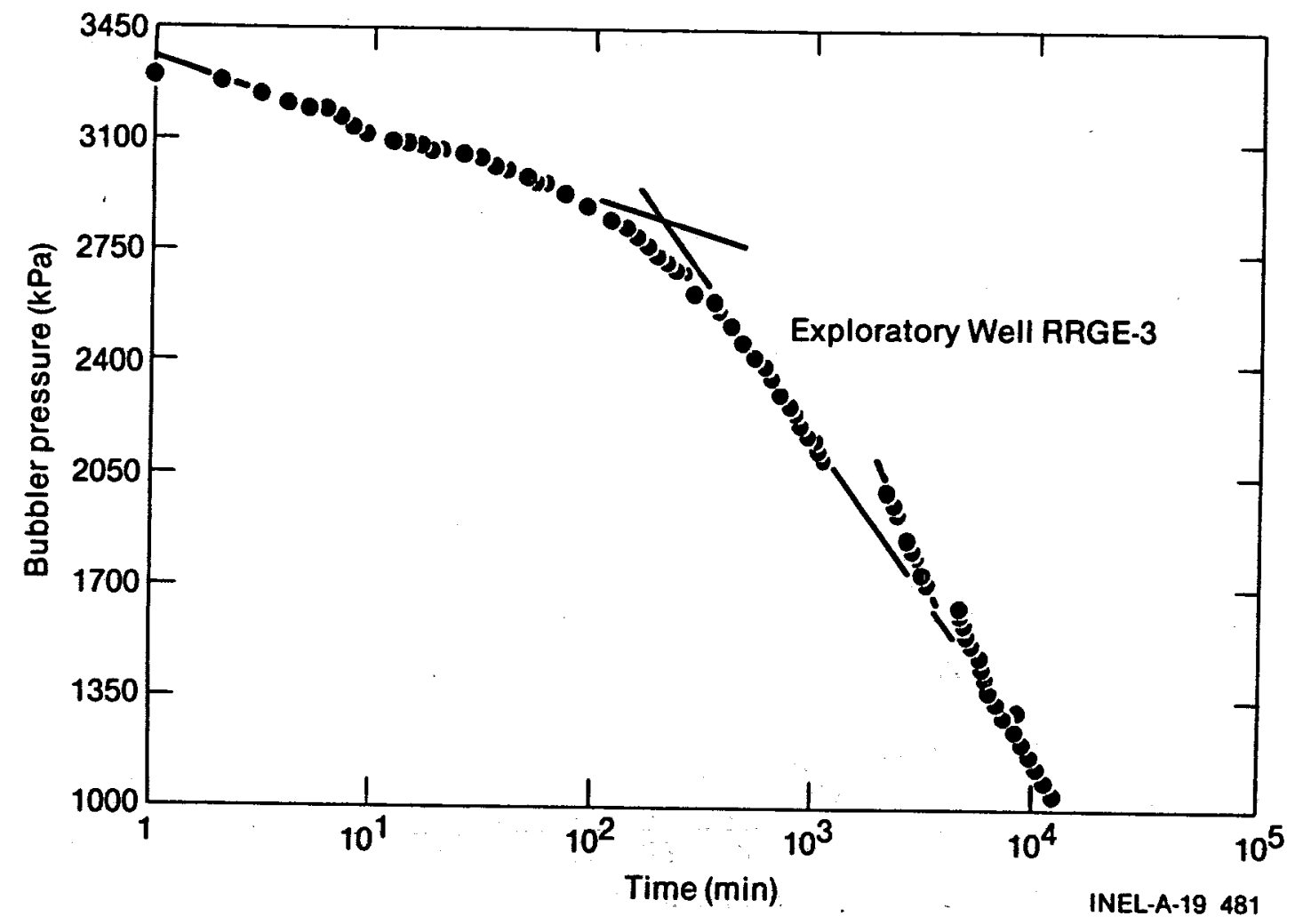

Figure 49. Drawdown during production test of well RRGE-3, March 19, 1981 at an average discharge rate of 44.2 L/s for 250 hours with numerous pump outages. 


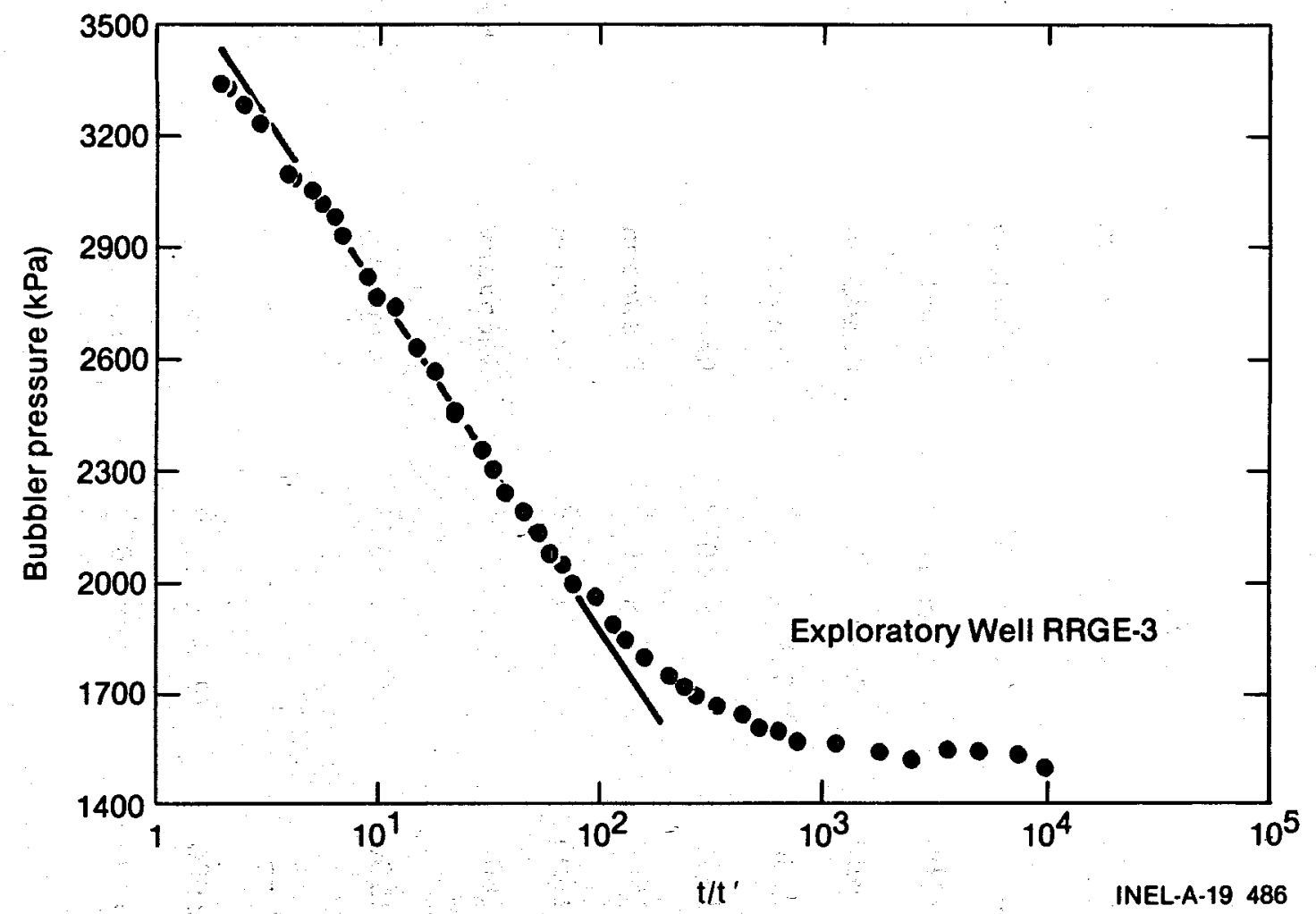

Figure 50. Recovery from production test of well RRGE-3, March 19, 1981 at an average discharge rate of $44.2 \mathrm{~L} / \mathrm{s}$ for 250 hours with numerous pump outages.

highest flow rate shows a significant increase in well parameters. The reason for the apparent decline in magnitude of well parameters with increasing discharge rates is thought to be due to fracture permeability. The "boundaries" which are seen in only some of the well tests and at various times are inconclusive. The apparent boundaries could be either an aquifer boundary related to the fracture permeability or a thermal boundary related to reservoir temperatures.

The 24-hour specific capacities ranged from 0.01 to $0.06(\mathrm{~L} / \mathrm{s}) / \mathrm{kPa}$. The mean value is $0.04(\mathrm{~L} / \mathrm{s}) / \mathrm{kPa}$. There is a slight decline in specific capacity as the well discharges at higher rates. However, the magnitude of the decline is statistically insignificant. The productivity curve is plotted in Figure 51. The two curves probably define the bounds of the wells productivity curve. It is possible that the equation is a quadratic, due to the fractured nature of the reservoir.

The three sidetrack legs in RRGE-3 are open to production between the bottom of the 25 -cm casing and total depth at $1791 \mathrm{~m}$ (Leg A), $1686 \mathrm{~m}$ (Leg B), and $1804 \mathrm{~m}$ (Leg C). No fluid losses were reported in these intervals during drilling.

Temperature logs indicate two possible production zones in Leg A at approximately 1600 and $1634 \mathrm{~m}$ and one possible zone in Leg C at $1550 \mathrm{~m}$. Caliper logs show hole enlargement in the intervals 1664 to $1678 \mathrm{~m}$ and 1743 to $1753 \mathrm{~m}$ in Leg C and the interval 1637 to $1643 \mathrm{~m}$ in Leg A. No flow meter logs are available for RRGE-3. Available televiewer logs indicate probable significant fracturing at approximately 1490 and $1641 \mathrm{~m}$ in Leg C. Less significant, possibly sealed fractures occur at depths of $1499 \mathrm{~m}, 1546 \mathrm{~m}$, and in the interval 1786 to $1794 \mathrm{~m}$. Televiewer coverage is available only for sidetrack Leg C.

Borehole information leading to identification of possible producing zones in RRGE-3 is summarized in Section 3, Figure 14. In sidetrack Leg A, the most significant contributory zone is at approximately 1600 to 
Table 21. Summary of well parameters at well RRGE-3

\begin{tabular}{|c|c|c|c|c|c|c|}
\hline $\begin{array}{l}\text { Start } \\
\text { Date } \\
\end{array}$ & $\begin{array}{c}Q \\
(L / s) \\
\end{array}$ & $\begin{array}{c}Q / s_{10} \\
{[(\mathrm{~L} / \mathrm{s}) /(\mathrm{kPa}) \log \text { cycle }]}\end{array}$ & $\begin{array}{c}\mathrm{kH}_{\mathrm{a}} \\
(\mathrm{mD} \cdot \mathrm{m}) \\
\end{array}$ & $\begin{array}{c}T_{a} \\
\left(\mathrm{~m}^{2} / \mathrm{s}\right) \\
\end{array}$ & Test & $\begin{array}{l}\text { Boundary } \\
\text { (min) }\end{array}$ \\
\hline $06 / 08 / 76$ & 8.6 & $\begin{array}{l}0.1 \\
0.05\end{array}$ & $\begin{array}{l}3700 \\
1700\end{array}$ & $\begin{array}{l}1.7 \times 10^{-4} \\
7.8 \times 10^{-5}\end{array}$ & $\begin{array}{l}\text { Drawdown } \\
\text { Recovery }\end{array}$ & $\begin{array}{l}\text { No } \\
\text { No }\end{array}$ \\
\hline $03 / 08 / 77$ & 22.1 & 0.1 & 4200 & $1.9 \times 10^{-4}$ & Drawdown & No \\
\hline $06 / 06 / 77$ & 37.9 & 0.03 & 2200 & $1 \times 10^{-4}$ & Drawdown ${ }^{a}$ & No \\
\hline $06 / 29 / 77$ & 49.6 & 0.02 & 600 & $2.9 \times 10^{-5}$ & Drawdown & No \\
\hline $07 / 06 / 77$ & 37.9 & $\begin{array}{l}0.034 \\
0.048 \\
0.05\end{array}$ & $\begin{array}{l}1250 \\
1800\end{array}$ & $\begin{array}{l}5.9 \times 10^{-5} \\
8.5 \times 10^{-5}\end{array}$ & $\begin{array}{l}\text { Drawdown } \\
\text { Recovery }\end{array}$ & $\begin{array}{c}3325 \\
\text { No }\end{array}$ \\
\hline $11 / 17 / 77$ & 37.9 & 0.04 & 1600 & $7.5 \times 10^{-5}$ & Drawdown & No \\
\hline $11 / 28 / 77$ & 37.9 & $\begin{array}{l}0.04 \\
0.06 \\
0.04 \\
0.07\end{array}$ & $\begin{array}{l}1600 \\
1600\end{array}$ & $\begin{array}{l}7 \times 10^{-5} \\
7 \times 10^{-5}\end{array}$ & $\begin{array}{l}\text { Drawdown } \\
\text { Recovery }\end{array}$ & $\begin{array}{l}8500 \\
6570\end{array}$ \\
\hline $01 / 31 / 78$ & 41 & $\begin{array}{l}0.03 \\
0.05\end{array}$ & 1200 & $5.8 \times 10^{-7}$ & Drawdown & 3400 \\
\hline $05 / 14 / 80$ & 44.2 & -- & - & - & -- & \\
\hline $03 / 19 / 81$ & 44.2 & $\begin{array}{l}0.08 \\
0.04 \\
0.05\end{array}$ & $\begin{array}{l}2900 \\
1700\end{array}$ & $\begin{array}{l}1.3 \times 10^{-4} \\
8 \times 10^{-5}\end{array}$ & $\begin{array}{l}\text { Drawdown } \\
\text { Recovery }\end{array}$ & 400 \\
\hline
\end{tabular}

a. Possible bubbler tube error. 


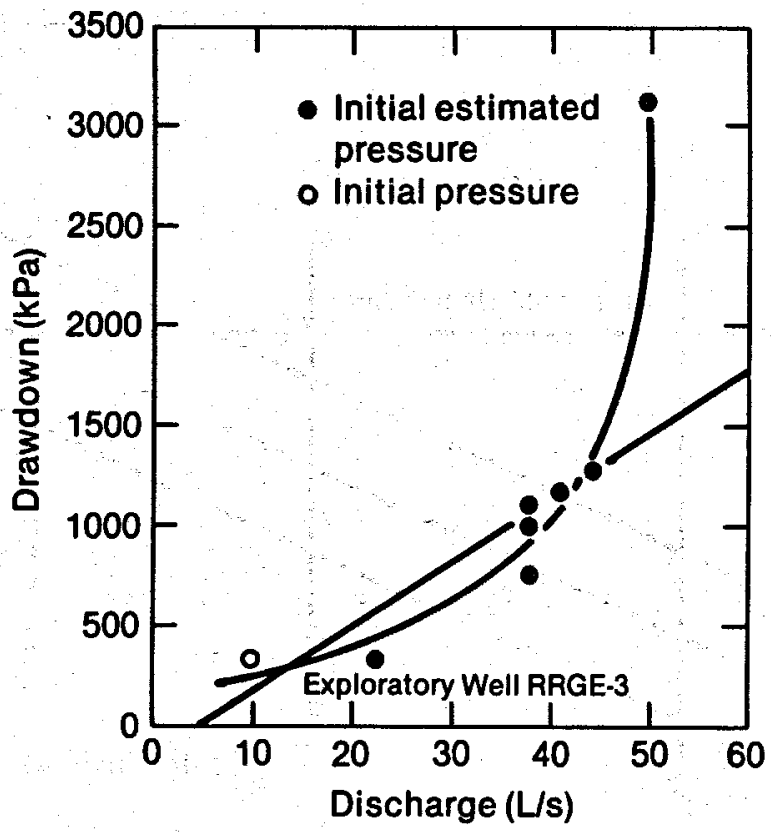

INEL-A-19 493

Figure 51. Productivity curve of 24-hour data from exploratory well RRGE-3.

$1650 \mathrm{~m}$. In sidetrack Leg $\mathrm{C}$, the most significant zones are at approximately 1550 and $1650 \mathrm{~m}$. The probable maximum sustained free-flowing artesian capability of well RRGE-3 is 12 to $13 \mathrm{~L} / \mathrm{s}$. Predicted wellhead pressure decline at a range of rates and times is shown in Figure 52. The predicted response is based on the following assumptions:

1. The intended use will be $85 \%$ for a period of three to five years.

2. The estimated hot shut-in wellhead pressure is $970 \mathrm{kPa}$.

3. The minimum wellhead pressure to sustain flow is $70 \mathrm{kPa}$.

4. The available drawdown for free flow is $900 \mathrm{kPa}$.

5. Projected drawdown is described by wellhead pressure, pressure $=180 \log$ time $(\mathrm{kPa})$.

6. No boundaries or interference drawdown or buildup are experienced.

With these assumptions, the available drawdown of $900 \mathrm{kPa}$ would be exhausted after three years of $85 \%$ sustained use at 12 to $13 \mathrm{~L} / \mathrm{s}$.

An estimation of well discharge versus wellbore drawdown from static conditions is given in Figure 53. At the higher rates $(>30 \mathrm{~L} / \mathrm{s})$, the discharge temperature will be between 145 and $150^{\circ} \mathrm{C}$.

4.5.4 Well RRGP-4. The Raft River well designated RRGP-4 was originally constructed and tested as an injection well. As such, the well carried the designation RRGI-4. Completion of the well to the original total depth of $866 \mathrm{~m}$ was achieved May 4, 1977. After a period of testing that spanned about one year, the well was drilled into the production zone of the geothermal reservoir. The extension was completed October 29, 1979 at a depth of $1654 \mathrm{~m}$. Primarily due to low artesian flow rates and the absence of significant fractures, a decision was made to construct a second leg within the production zone. The second leg was completed at $1559 \mathrm{~m}$ November 15,1978 . The artesian flow rate was still considered unsatisfactory after completion of the second leg in RRGP-4. In an effort to improve the artesian flow, an attempt was 


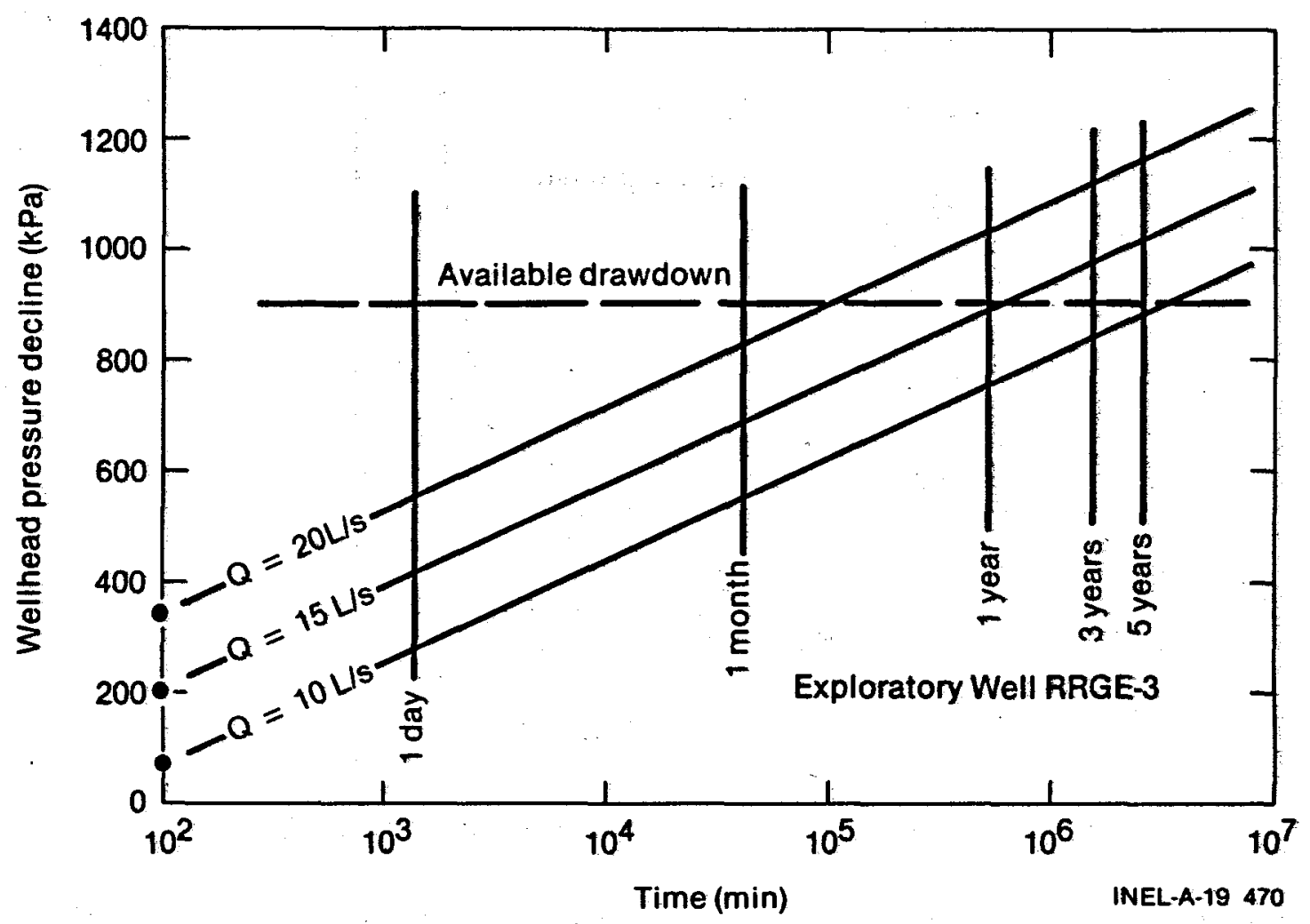

Figure 52. Predicted wellhead pressure decline for artesian flowing conditions at well RRGE-3.

made to induce fractures within the formation immediately surrounding the well. A portion of the previously open hole was closed off by cementing a liner in position to a depth of $1433 \mathrm{~m}$. Sand was placed in the bottom of the well to reduce the open space to a $61-\mathrm{m}$ segment 1433 to $1494 \mathrm{~m}$ ). The Dentritic or Kiel hydraulic fracturing technique was employed. A total of $49169 \mathrm{~kg}$ of sand and $1275656 \mathrm{~L}$ of speciallytreated water was used during the fracturing effort. 66 Emplacement of the liner prior to hydraulic fracturing closed off the prestimulation production zone. 67 The fracturing effort was successful because it treated fractures but allowed the well to flow under artesian conditions at rates from 4.7 to $14.2 \mathrm{~L} / \mathrm{s}$. These flow rates do not differ significantly from the artesian flow rates observed from the deepened borehole prior to stimulation. During the year following May 1977, when RRGI-4 was originally completed, a large number of both artesian flow and injection tests were conducted. The discharge rates for the artesian flow tests were in the range of 6 to $12 \mathrm{~L} / \mathrm{s}$ and most tests were of relatively short duration (Table 22). Two notable exceptions are the November 2, 1977 test which lasted 167 hours and the May 30, 1978 injection test. These are the only tests of sufficient length (greater than 24 hours) to analyze for reservoir characteristics. During the November 2, 1977 test, temperature appeared to stabilize after about 120 min (Figure 54). The variation in observed temperature beyond the 120 -min mark may be due to instrument insensitivity in slight variations in the discharge rate.

The average temperature after stabilization was taken to be $113^{\circ} \mathrm{C}$. Interpreting reservoir characteristics from the pressure response curve in Figure 54 suggests $\mathrm{kH}_{\mathrm{a}}=11000 \mathrm{mD} \cdot \mathrm{m}, \mathrm{T}_{\mathrm{a}}=3.9 \times 10^{-4} \mathrm{~m}^{2} / \mathrm{s}$, and $\mathrm{Q} / \mathrm{s}_{10}=0.22(\mathrm{~L} / \mathrm{s}) /(\mathrm{kPa}) / \log$ cycle.

The May 30, 1978 injection test was conducted despite several pump outages. The longest outage was $60 \mathrm{~min}$; generally, outages lasted for less than $15 \mathrm{~min}$. During the test, pump outages accounted for less than $115 \mathrm{~min}$ of the 13,000-min test. Following each pump outage, the injection rate was returned to and maintained at $44 \mathrm{~L} / \mathrm{s}$. Wellhead temperature of the injected fluid appeared to stabilize at $133^{\circ} \mathrm{C}$ after $170 \mathrm{~min}$ of injection (Figure 55). The temperature reflects, as expected, pump outages but variations about 


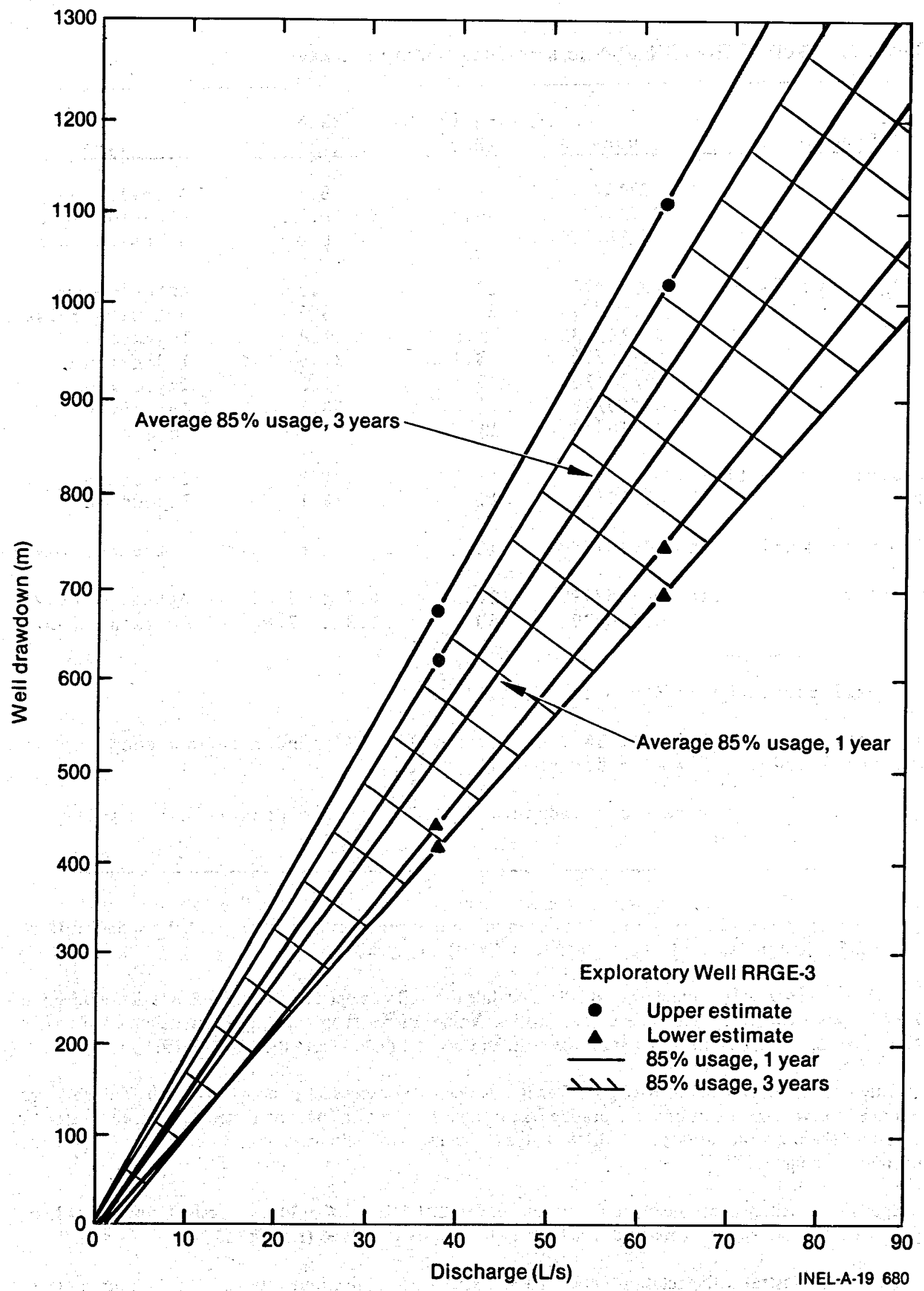

Figure 53. Expected drawdown versus flow rate at exploratory well RRGE-3 (not including interference effects). 


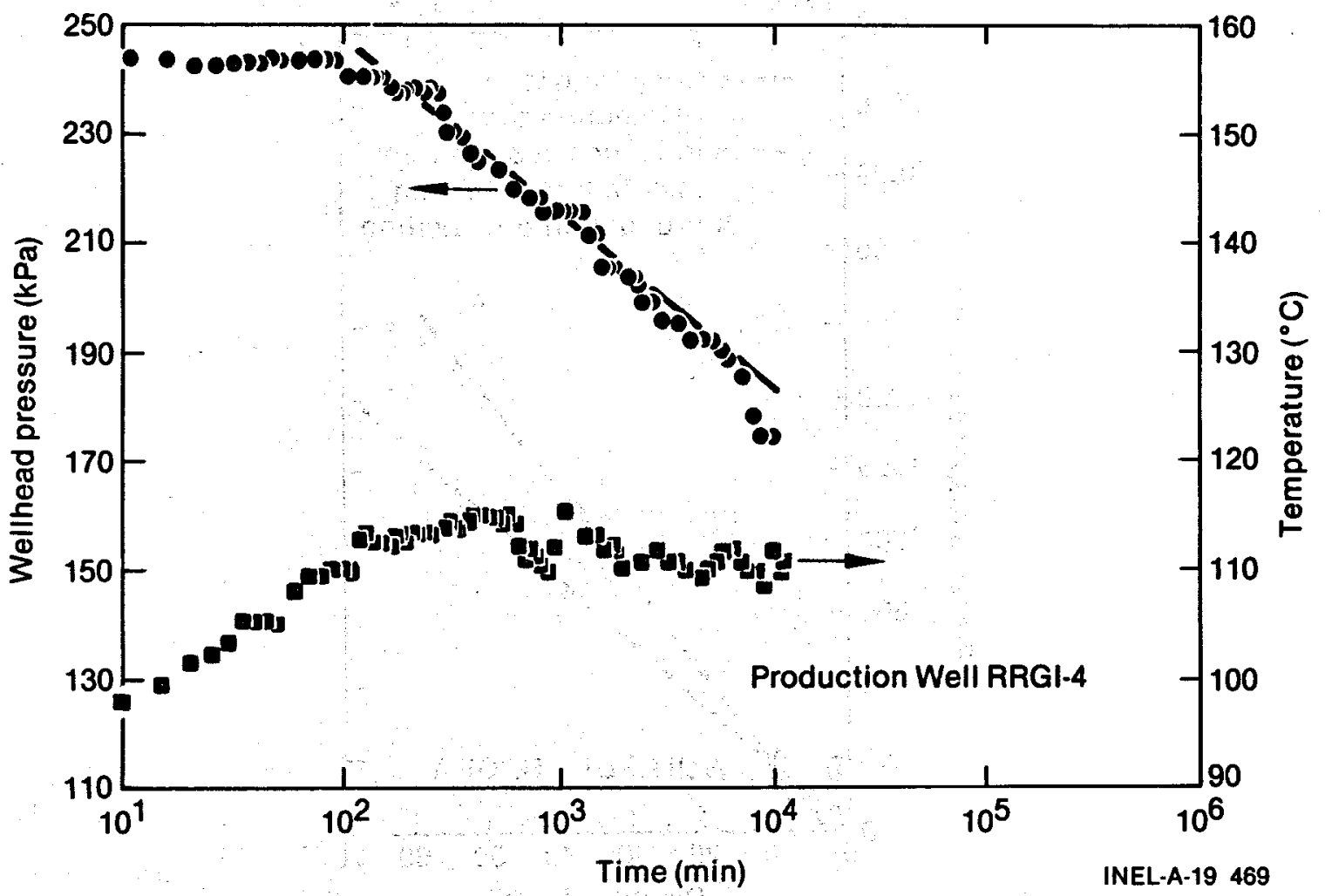

Figure 54. Wellhead pressure and temperature during production test of well RRGI-4 November 2, 1977 at a discharge rate of $6.3 \mathrm{~L} / \mathrm{s}$ for $167 /$ continuous hours.

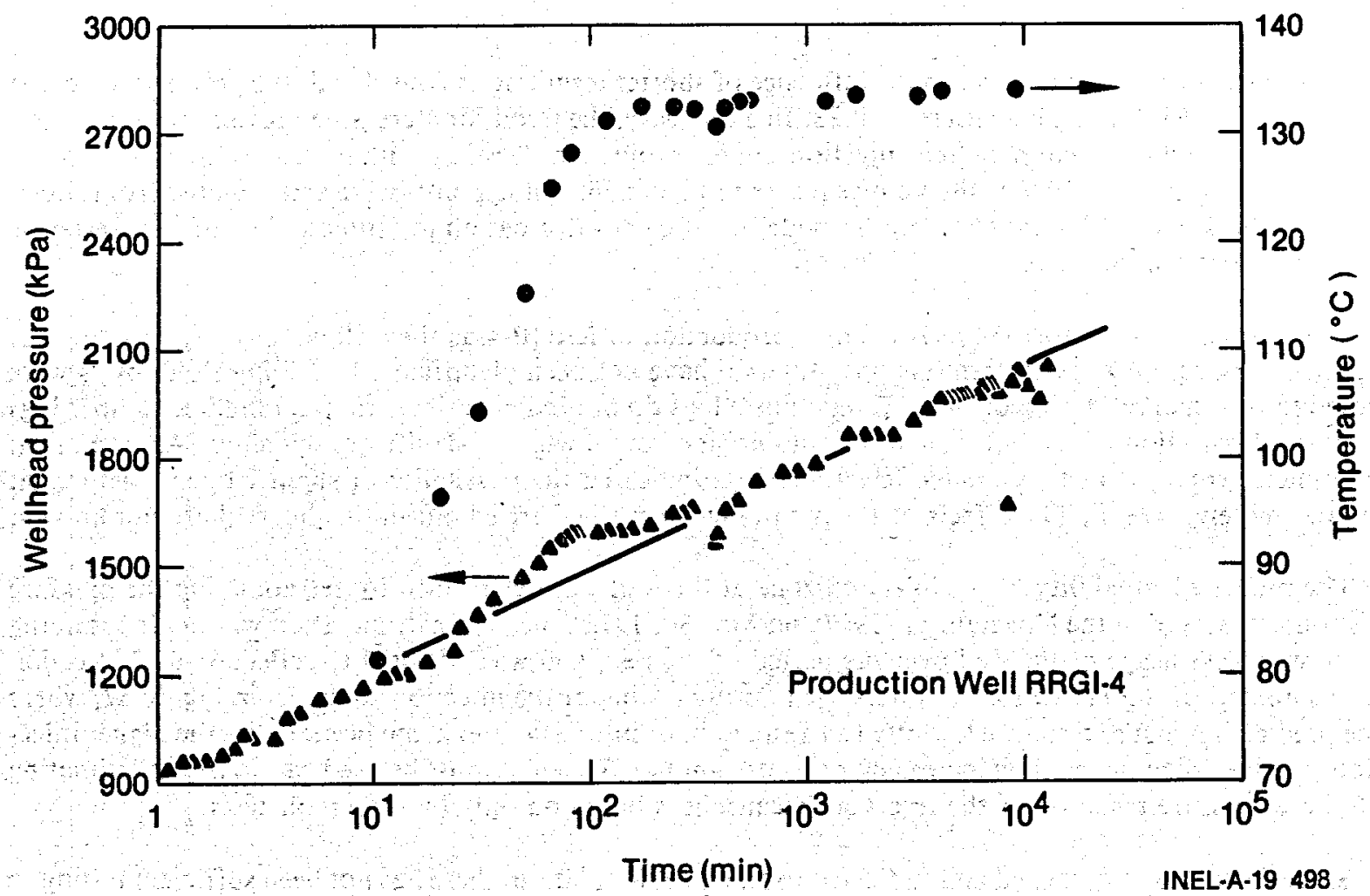

Figure 55. Wellhead pressure and temperature during injection test of well RRGI-4, May 30, 1978 at a discharge rate of . 44.1 L/s for 221 continuous hours. 


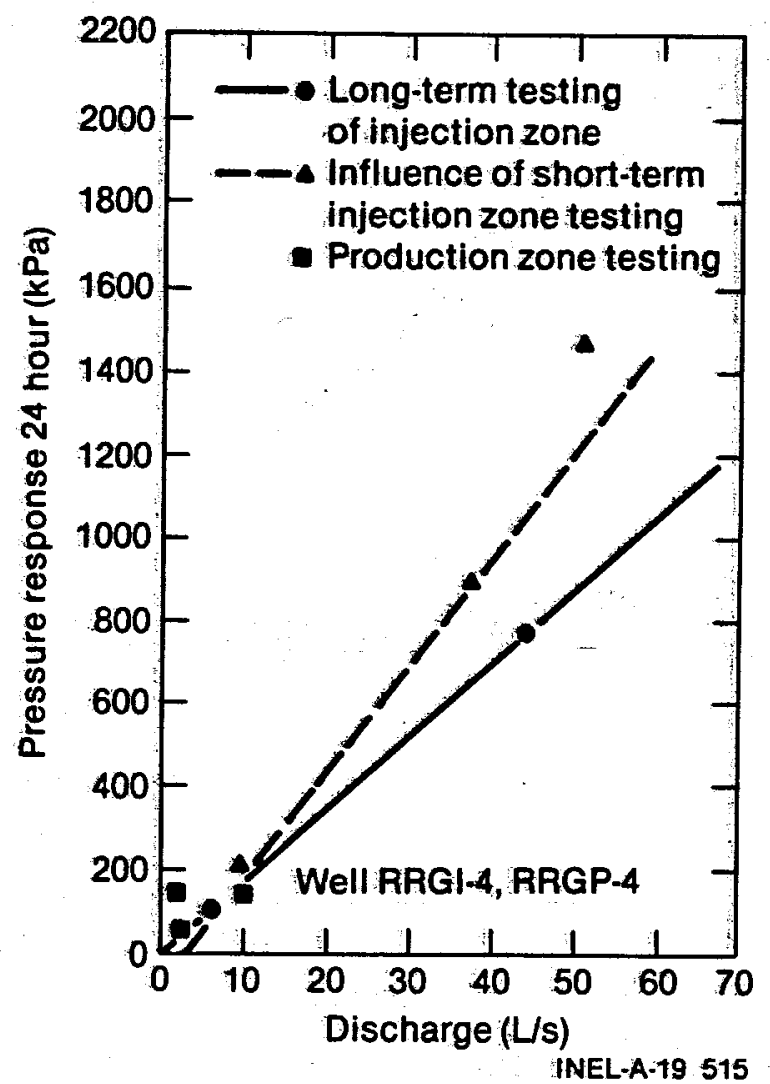

Figure 56. Productivity curve of 24-hour data from production well RRGP-4.

best-fit line, the $\mathrm{r}^{2}$ value is 1 . When the influence of shorter term tests is considered, the productivity curve becomes $y=-68.2+25.5 \mathrm{x}$, with $\mathrm{r}^{2}=0.88$. In either case, the trend for increasing pressure response, i.e., increasing pressure buildup in the injection zone, is obvious. Testing within the production zone at RRGP-4 after October 1978 is shown by squares in Figure 56. These points were extrapolated from shortduration (less than 24 hours) tests, and provide insufficient information to estimate the pressure response to various production rates.

The interval of 1434 to $1559 \mathrm{~m}$ is open to production in RRGP-4 as the well is presently constructed. Specific production zones within this open interval have not been identified. No drilling fluid losses were noted in this interval during drilling. Temperature logs do not indicate significant anomalies. Caliper logs indicate this section of the borehole to be smooth and round with no significant openings. An attempted flow meter survey failed. Available televiewer logs indicated the possibility of slightly open fractures at approximately $1478 \mathrm{~m}$. The effects of the hydraulic fracturing carried out in this interval are not known.

The predicted capability of the injection zone at the well was determined by extrapolating the pressure response observed in the November 2, 1977 and May 30, 1978 tests. The extrapolation was made assuming there was $85 \%$ usage of the well over the period of interest, and was adjusted to reflect $65.6^{\circ} \mathrm{C}$ injection fluids instead of the 117 to $133^{\circ} \mathrm{C}$ waters used during testing of the injection zone. From Figure 57, where the predicted pressure response is plotted as a function of injection rate, it can be seen that the higher injection rates are accompanied by increasing pressure buildup. This plot must be used cautiously in estimating ultimate pressure response of the reservoir because it is based on only two reservoir tests.

Since the well was deepened and subjected to fracture stimulation, there has not been sufficient testing to evaluate reservoir properties or performance. 


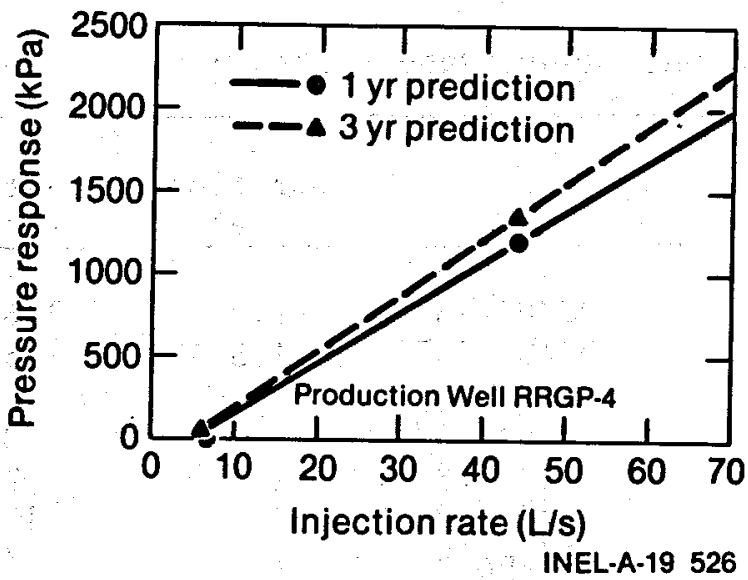

Figure 57. Expected pressure response versus injection rate at production well RRGP-4 (not including interference effects). This plot is based on data obtained while production well RRGP-4 was at a total depth of $866 \mathrm{~m}$.

4.5.5 Well RRGP-5. The drilling and development of RRGP-5 can be divided into three phases. Drilling began early in May 1978. The initial drilling activity was completed July 8, 1978 at a total depth of $1493 \mathrm{~m}$. The upper portion of the well, the portion within the injection zone, was tested after placing a cement plug at $1138 \mathrm{~m}$. On August 23, 1978, an attempt as made to drill through the cement plug and reopen the deep completion. This effort did not work; instead a new deep-completion leg was drilled around the plug. This new leg was completed at $1501 \mathrm{~m}$ on September 15, 1978. After about nine months of testing (Table 23), a decision was made to attempt to stimulate the well by hydro-fracturing.

The hydraulic fracturing effort was undertaken on November 12, 1979. Preparations for the test involved installation of an 18-cm cemented liner between 963 and $1397 \mathrm{~m}$ and placement of sand in the bottom 38-m of the well in order to isolate a $61-\mathrm{m}$ section for stimulation. These preparations effectively clos- ed off previously existing fracture zones of the well. Using a massive, planar, vertical fracture design, the treatment employed $1211 \mathrm{~m}^{3}$ of fluid and $195000 \mathrm{~kg}$ of "frac" sand. Post-stimulation testing indicates that the well has not achieved pretreatment flow capacities. ${ }^{68}$ Reservoir evaluation tests conducted following the stimulation effort have not been analyzed.

Tests conducted within the injection zone at RRGP-5 were of very short duration; because they lasted less than 24 hours, these tests have not been reviewed in this report.

Three tests out of those conducted following completion of the well within the production zone exceeded 24 hours in duration. These were the tests on November 1, 1978, May 16, 1979, and June 26, 1979 (Table 23).

A semi-logarithmic plot of the pressure response and temperature data collected during the November 1 , 1978 test is shown in Figure 58. Instrumentation failure resulted in the missing data between 42 and $160 \mathrm{~min}$. Pressure data collected between 1.5 and $42 \mathrm{~min}$ of testing sharply define a straight line in Figure 58. Reservoir properties estimated from the data are $\mathrm{kH}_{\mathrm{a}}=4900 \mathrm{mD} . \mathrm{m}, \mathrm{T}_{\mathrm{a}}=2.0 \times 10^{-4} \mathrm{~m}^{2} / \mathrm{s}$, and $\mathrm{Q} / \mathrm{s}_{10}=0.12(\mathrm{~L} / \mathrm{s}) /(\mathrm{kPa}) / \log$ cycle. Data plotted after $160 \mathrm{~min}$ do not form a definitive straight line; the reason for this is not fully understood. Additionally, any line fit to these data suggests reservoir parameters that are inconsistent with other test results. Thus, in summarizing reservoir evaluation at RRGP-5, late-time data from the November 1, 1978 test have been neglected.

Figure 59 presents the pressure response and temperature observed during the May 16, 1979 test. Wellhead temperature appears to have stabilized after $30 \mathrm{~min}$ of production, beyond this point the temperature was $125^{\circ} \mathrm{C} \pm 1{ }^{\circ} \mathrm{C}$. Pressure response data collected for time exceeding 200 min fall on a reasonably well defined straight line despite the influence of several pump outages. The pump outages 


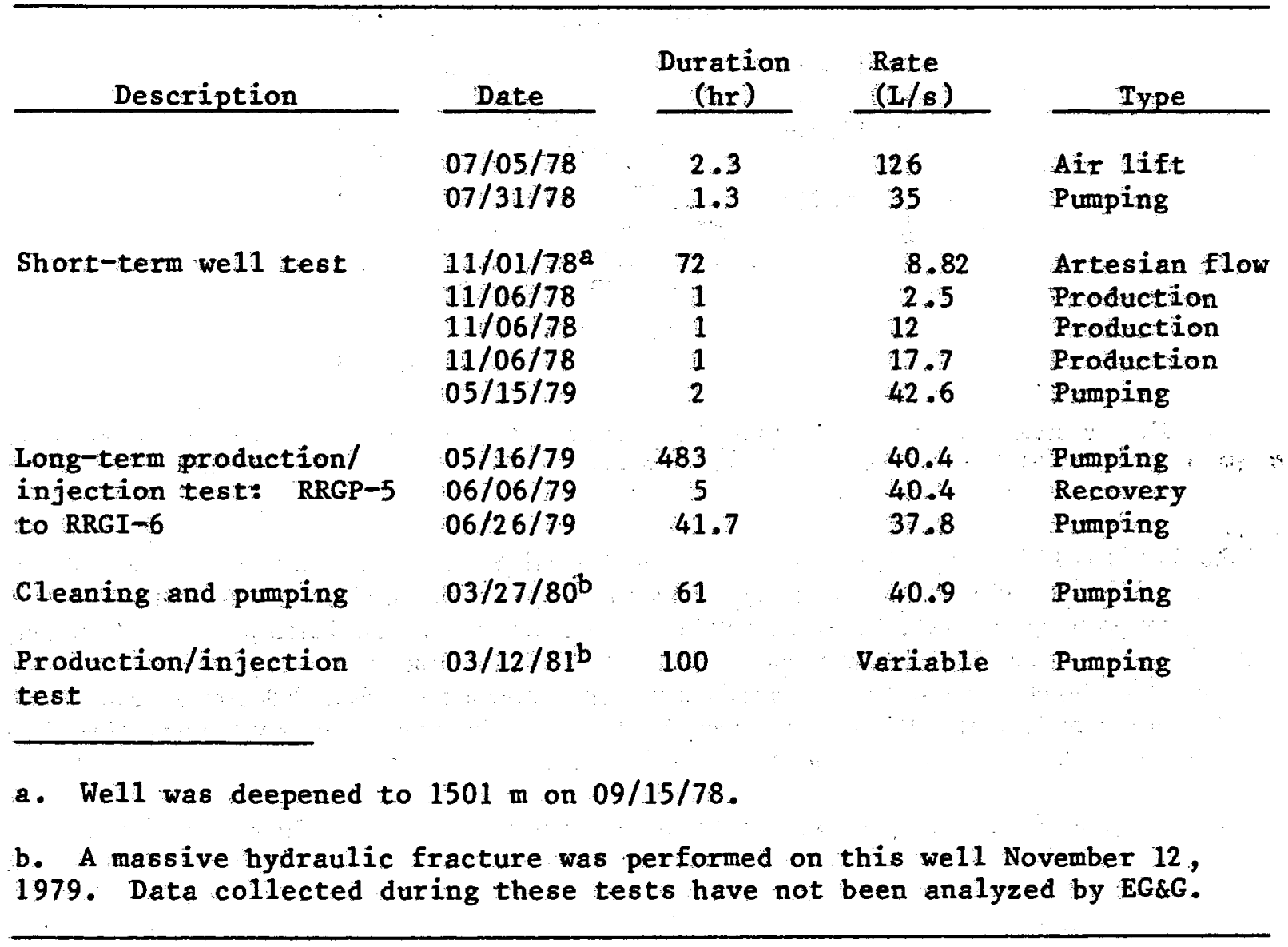

cause a sharp increase in the pressure response data, one such increase is observed at $2,500 \mathrm{~min}$ in Figure 59. Estimating reservoir properties from the straight line fit of data collected after 200 min gives $\mathrm{kH}_{\mathrm{a}}=6300 \mathrm{mD} \cdot \mathrm{m}, \mathrm{T}_{\mathrm{a}}=2.6 \times 10^{-4} \mathrm{~m}^{2} / \mathrm{s}$, and $\mathrm{Q} / \mathrm{s}_{10}=0.15(\mathrm{~L} / \mathrm{s}) /(\mathrm{kPa}) / \log$ cycle.

Pressure response observed during the production test of June 26, 1979 is shown in Figure 60. Temperature observations during this test are unavailable; however, it is possible to infer from the 11-1-78 and 5-16-79 tests that temperature had stabilized by $100 \mathrm{~min}$. A straight line was fit to pressure data obtained after $250 \mathrm{~min}$. The pressure response during this time may be influenced by varying discharge rates and pump outages; the pump outage at $1,500 \mathrm{~min}$ is the only one confirmed by test records. Reservoir properties estimated from the fitted straight line have the values: $\mathrm{kH}_{\mathrm{a}}=16500 \mathrm{mD} . \mathrm{m}, \mathrm{T}_{\mathrm{a}}=6.8 \mathrm{x}$ $10^{-4} \mathrm{~m}^{2} / \mathrm{s}$, and $\mathrm{Q} / \mathrm{s}_{10}=0.39(\mathrm{~L} / \mathrm{s}) /(\mathrm{kPa}) / \log$ cycle.

Stimulation of RRGP-5 was attempted, after the 1978-1979 testing period, using a hydraulic fracturing technique. Two tests conducted after the stimulation effort (Table 23) have not been analyzed by EG\&G; no post-stimulation estimate of reservoir properties is available.

Table 24 summarizes the estimated reservoir properties calculated from testing at RRGP-5. Averaging the estimates obtained for each test gives: $\mathrm{kH}_{\mathrm{a}}=9200 \mathrm{mD} . \mathrm{m}, \mathrm{T}_{\mathrm{a}}=3.8 \times 10^{-4} \mathrm{~m}^{2} / \mathrm{s}$, and $\mathrm{Q} / \mathrm{s}_{10}=$ $0.22(\mathrm{~L} / \mathrm{s}) /(\mathrm{kPa}) / \log$ cycle.

The specific capacity for these tests evaluated using the 24-hour pressure, ranges from 0.06 to $0.12(\mathrm{~L} / \mathrm{s}) / \mathrm{kPa}$ (Table 24). A productivity curve in which 24-hour pressure is plotted as a function of discharge rate is shown in Figure 61. The equation of the linear least squares fit is $y=66.25+7.70 x$, 


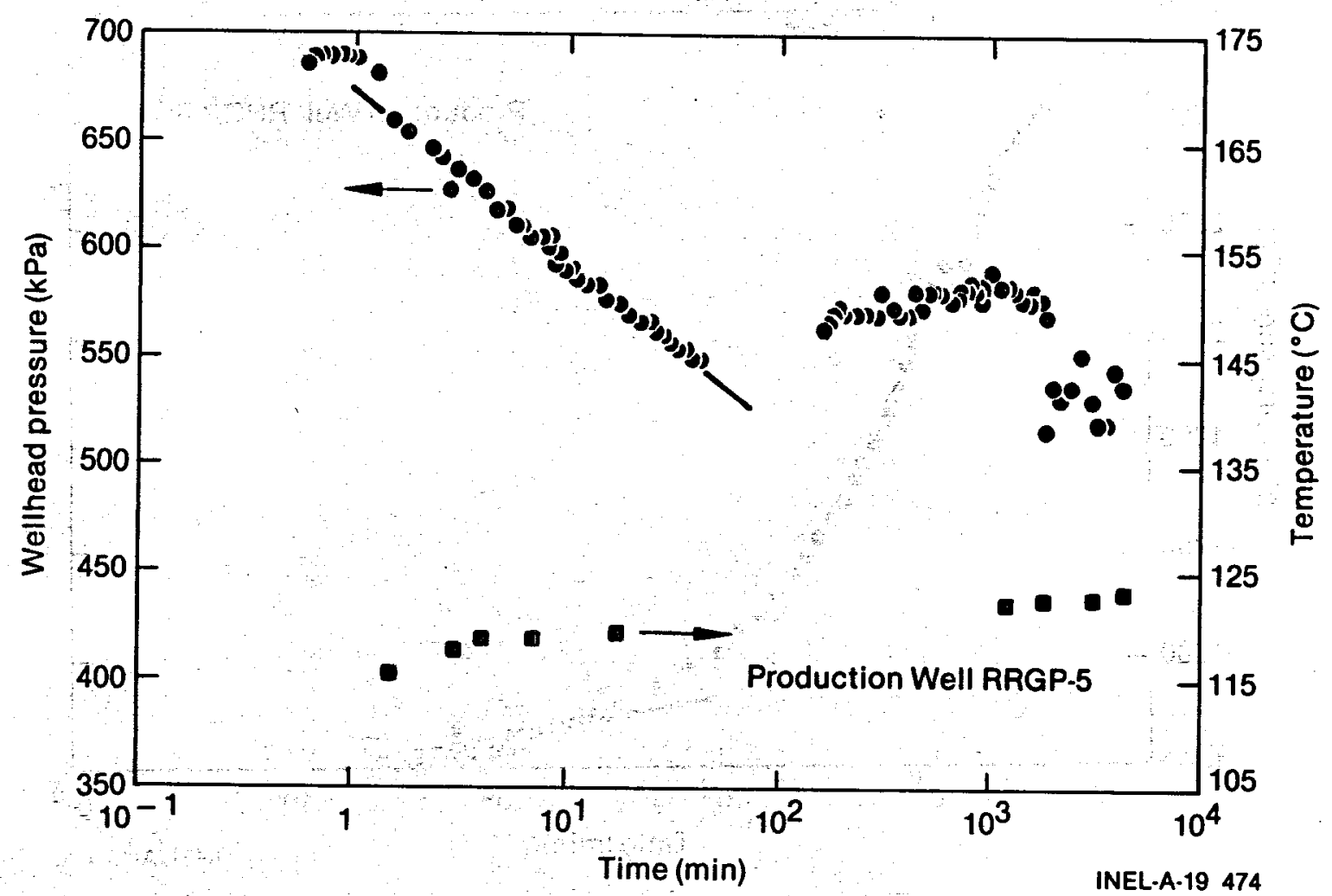

Figure 58. Wellhead pressure and temperature during production test of well RRGP-5, November 1, 1978 at a discharge rate of $8.82 \mathrm{~L} / \mathrm{s}$ for 72 continuous hours.

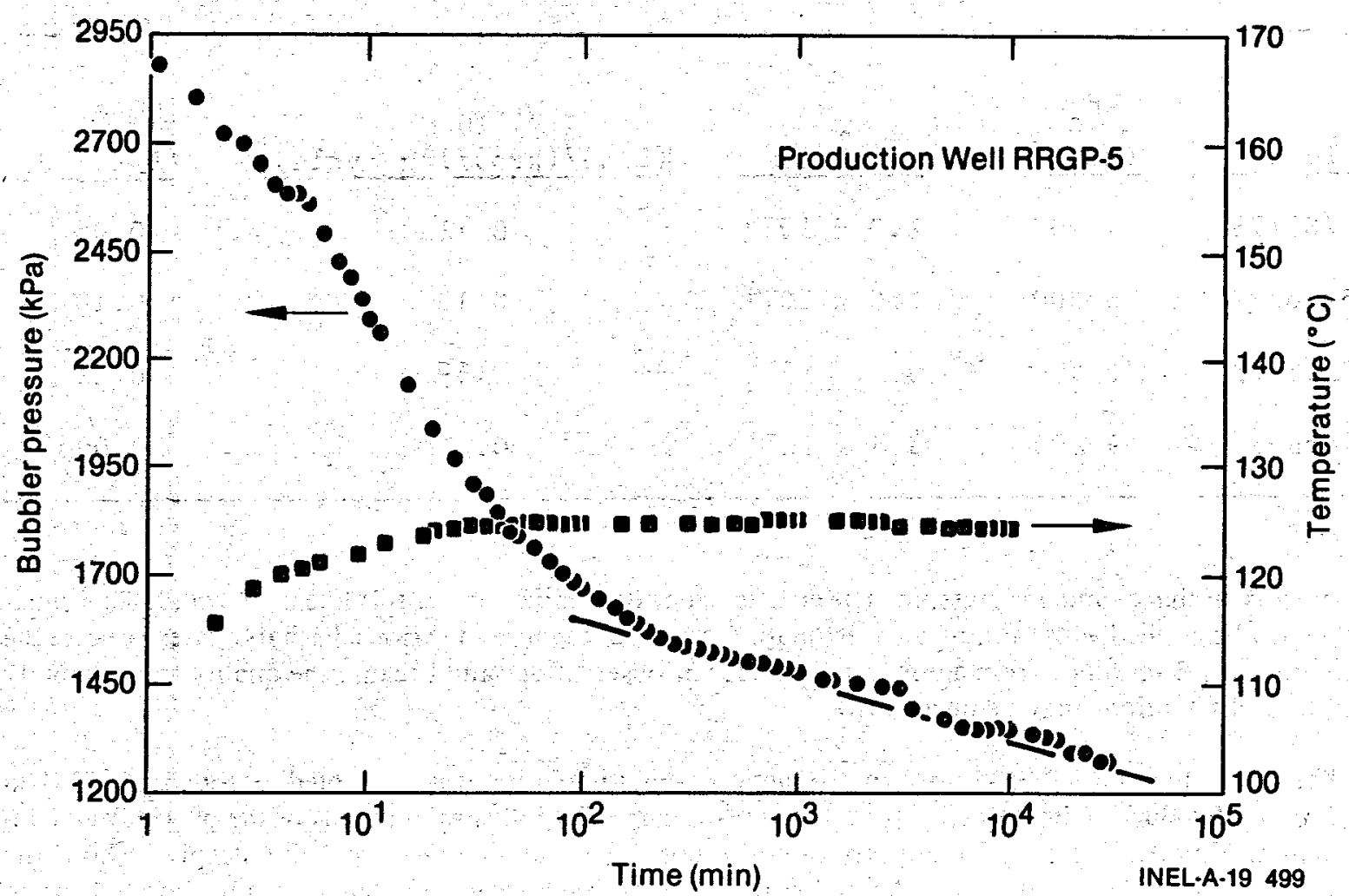

Figure 59. Bubbler pressure and wellhead temperature during production test of well RRGP-5, May 16, 1979 at a discharge rate of $40.4 \mathrm{~L} / \mathrm{s}$ from 483 continuous hours. 


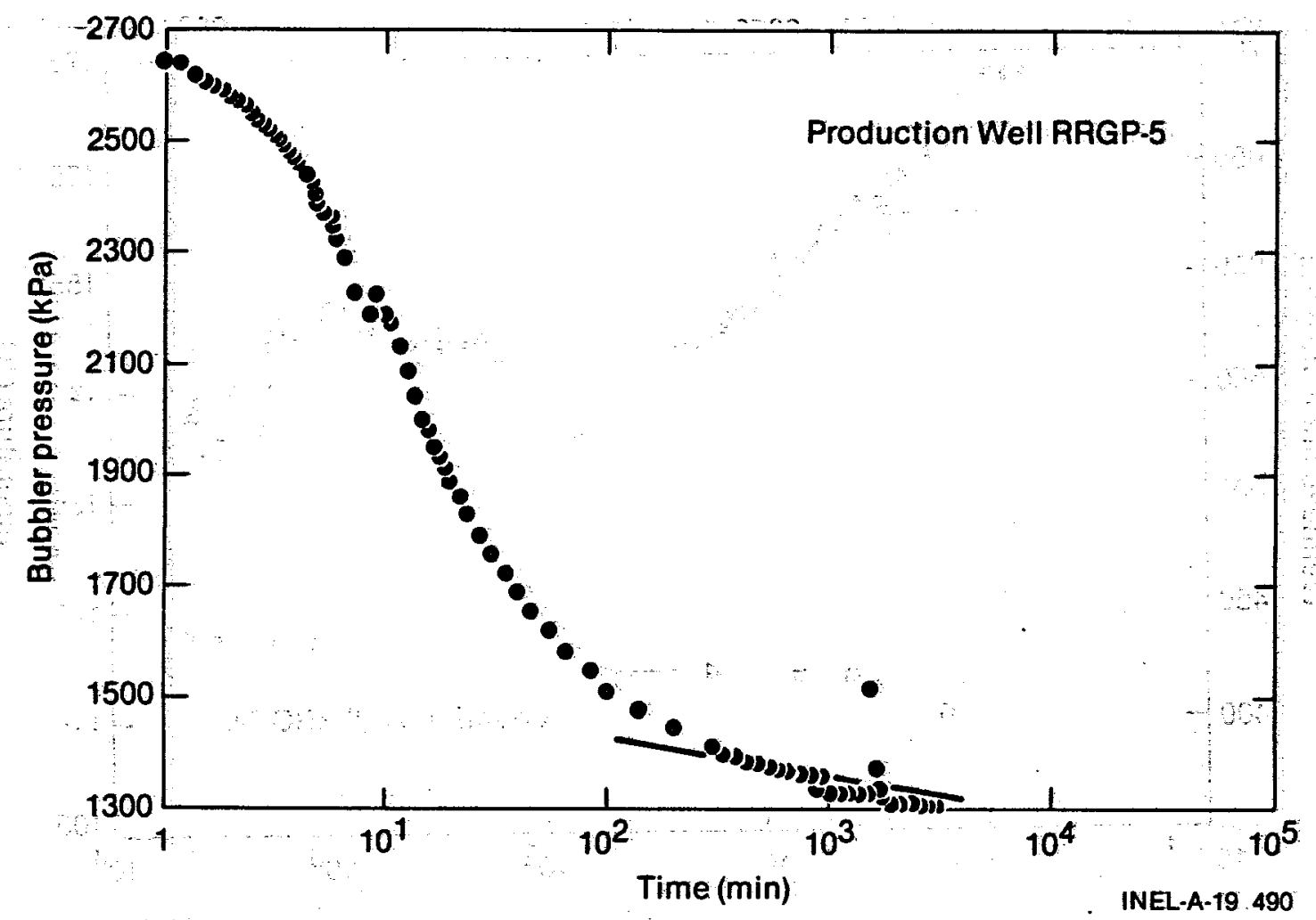

Figure 60. Wellhead pressure during production test of well RRGP-5, June 26,1979 at a discharge rate of $37.8 \mathrm{~L} / \mathrm{s}$ for 41.7 continuous hours.

Table 24. Summary of well parameters at RRGP-5

\begin{tabular}{|c|c|c|c|c|}
\hline Test & $\begin{array}{c}\mathrm{kH}_{\mathrm{a}} \\
\left(\mathrm{mD}^{\circ} \mathrm{m}\right) \\
\end{array}$ & $\begin{array}{c}T_{a} \\
\left(m^{2} / s\right) \\
\end{array}$ & $\begin{array}{c}Q / s_{10} \\
[(\mathrm{~L} / \mathrm{s}) /(\mathrm{kPa}) / \log \text { cycle })]\end{array}$ & $\begin{array}{c}Q / s_{2.4} \\
(\mathrm{~L} / \mathrm{s}) / \mathrm{kPa} \\
\end{array}$ \\
\hline $11 / 01 / 78$ & 4900 & $2.0 \times 10^{-4}$ & 0.12 & 0.06 \\
\hline $05 / 16 / 79$ & 6300 & $2.6 \times 10^{-4}$ & 0.15 & 0.10 \\
\hline $06 / 26 / 79$ & 16500 & $6.8 \times 10^{-4}$ & 0.39 & 0.12 \\
\hline Average & 9200 & $3.8 \times 10^{-4}$ & 0.22 & 0.09 \\
\hline
\end{tabular}

where $\mathrm{x}$ is discharge and $\mathrm{y}$ is pressure. The coefficient of determination for this line is $\mathrm{r}^{2}=0.9$. This equation must be applied with caution when estimating pressure response to various discharge rates because the equation was determined from a minimum number of observations and because the quality and reliability of those observations may be questioned.

The interval within RRGP-5 open to production after stimulation was attempted extends from $1397 \mathrm{~m}$ to $1501 \mathrm{~m}$. Production in the well is from fractures. Figures B-16 illustrates details of the present well construction. Significant fracturing appears to strike northeast and southwest and dip steeply in both the southeast and northwest directions. A number of identified fractures were isolated from the borehole when 


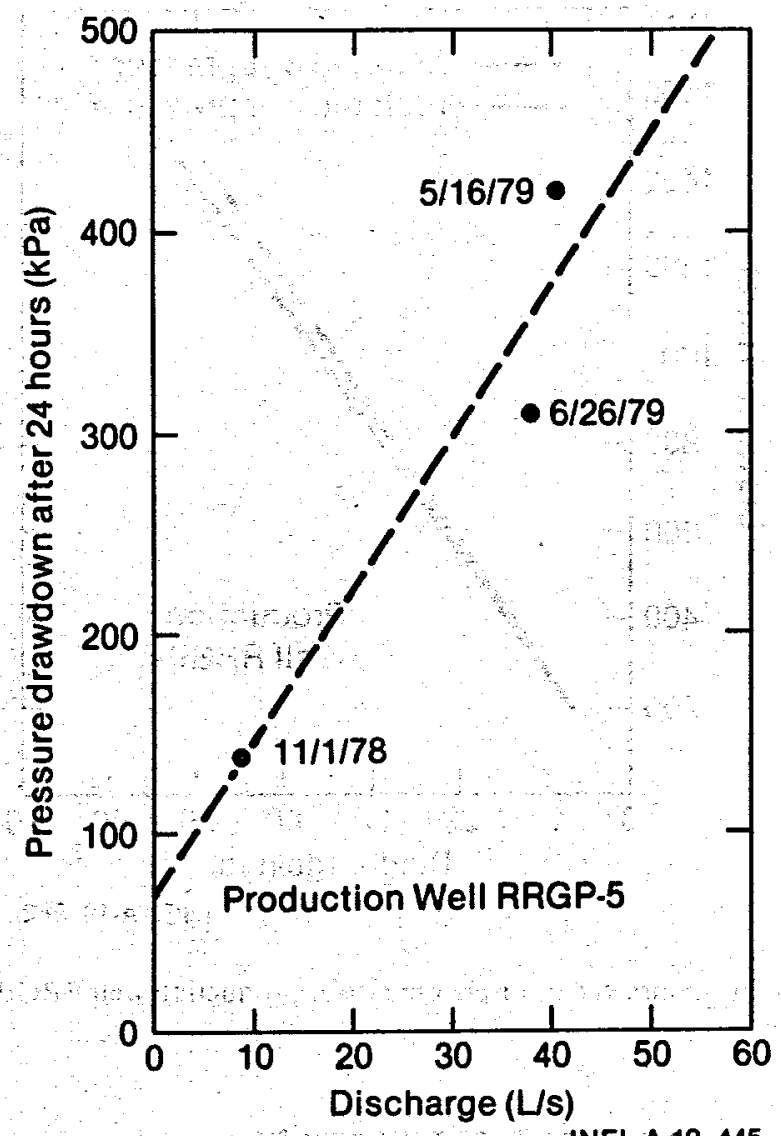

INEL-A-19 445

Figure 61. Productivity curve of 24 -hour data from production well RRGP-5.

- the 18-cm liner was installed in preparation for hydro-fracturing. Other producing zones may have been altered in the process of stimulation. A USGS televiewer log run after stimulation is not available for interpretation.

Determination of a definitive predicted capacity plot is not possible using the available data. Figure 62 graphs the expected pressure response as a function of discharge for one and three year periods.

4.5.6 Well RRGI-6. A list of five tests performed on well RRGI-6, for which sufficient data are available for analysis, is given in Table 25. Both injection and recovery data were collected for three of these tests.

A 72-hour injection test was conducted between January 10 to 13, 1979. Two short-term (one hour) pulse tests were performed before and after the 72-hour test to ascertain if injection had altered the wellbore. No changes were detected. Discharge during the test was $44.2 \mathrm{~L} / \mathrm{s}$. Pressure and temperature were measured at the surface and at a depth of $610 \mathrm{~m}$. The downhole pressure probe was very sensitive to temperature fluctuations and did not give reliable pressure readings until the temperature stabilized about $400 \mathrm{~min}$ into the test.

Plots of pressure and temperature during this test are shown in Figures 63 and 64 . The initial curvature of the pressure buildup curves is due to a gradual increase in pumping rate. The test rate of $44.2 \mathrm{~L} / \mathrm{s}$ was not reached until $8 \mathrm{~min}$ into the test. The change in slope in the pressure response graphs at about $400 \mathrm{~min}$ closely coincides with the stabilization of water temperature measured at a depth of $610 \mathrm{~m}$. The change in slope, therefore, is probably a thermal effect, and not related to any boundaries in the aquifer. Because of this, only the later slopes were analyzed for hydrologic parameters. 


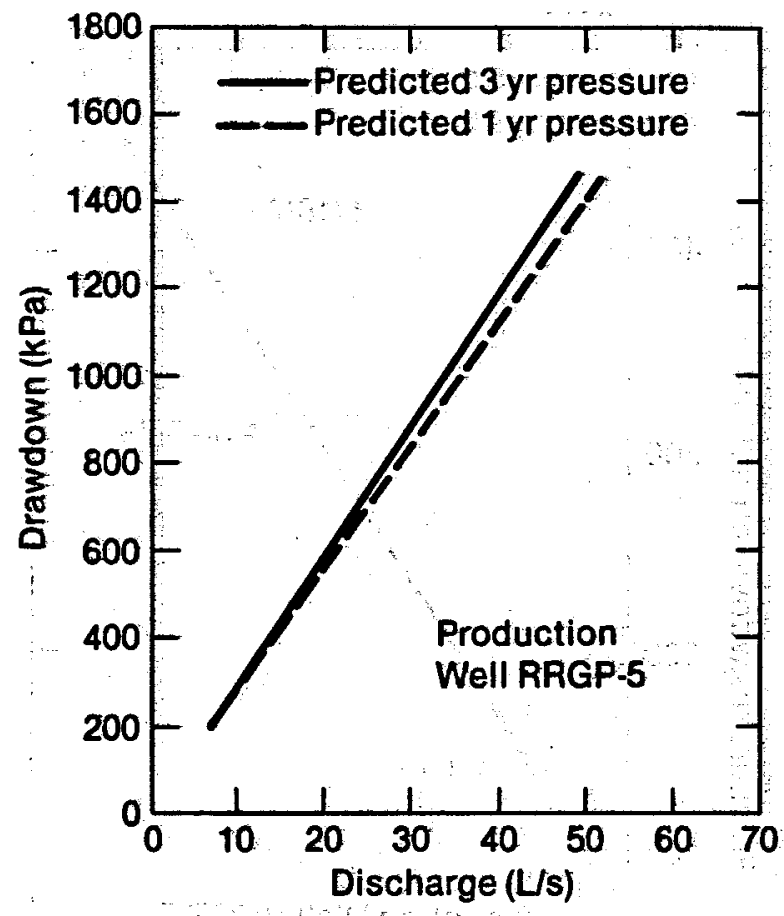

INEL-A-19 883

Figure 62. Expected pressure response versus discharge rate at production well RRGP-5 (not including interference tests).

Table 25. Well RRGI-6 performance testing activity

\begin{tabular}{lccccc}
\hline Description & Date & $\begin{array}{c}\text { Duration } \\
\text { (hr) }\end{array}$ & $\begin{array}{c}\text { Rate } \\
\text { (L/s) }\end{array}$ & & Type \\
\cline { 1 - 1 } From RRGE-2 to RRGI-6 & $01 / 10 / 79$ & 72 & 44.2 & Injection \\
From RRGE-2 to RRGI-6 & $03 / 10 / 79$ & 504 & 37.8 & Injection/Recovery \\
From RRGP-5 to RRGI-6 & $05 / 16 / 79$ & 500 & 40.4 & Injection/Recovery \\
From RRGE-3 to RRGI-6 & $05 / 14 / 80$ & 680 & 45.7 & Recovery \\
From RRGE-1 to RRGI-6 & $08 / 19 / 80$ & 190 & 56.8 & Injection/Recovery \\
\hline
\end{tabular}

The reservoir parameters determined from the wellhead pressure response are: $Q / \mathrm{s}_{10}=$ $0.39(\mathrm{~L} / \mathrm{s}) /(\mathrm{kPa}) / \log$ cycle, $\mathrm{kH}_{\mathrm{a}}-16000 \mathrm{mD} . \mathrm{m}$, and $\mathrm{T}_{\mathrm{a}}=2.1 \times 10^{-4} \mathrm{~m}^{2} / \mathrm{s}$. For the pressure changes recorded at $610 \mathrm{~m}$, the parameters are: $\mathrm{Q} / \mathrm{s}_{10}=0.40(\mathrm{~L} / \mathrm{s}) /(\mathrm{kPa}) / \log$ cycle, $\mathrm{kH}_{\mathrm{a}}=17000 \mathrm{mD} \cdot \mathrm{m}$, and $\mathrm{T}_{\mathrm{a}}=2.1 \times 10^{-4} \mathrm{~m}^{2} / \mathrm{s}$. These parameters are summarized in Table 26 .

A 21-day test (500 hours) was run during March 1979, with data collected during both injection and recovery. The flow rate during this test was $37.8 \mathrm{~L} / \mathrm{s}$. The change in wellhead pressure and temperature are shown in Figure 65 for the injection phase, and in Figure 66, the pressure is shown for the recovery phase. A change in slope of the injection pressure response curve can be observed at approximately the time temperature shows a sharp increase. Only the data collected after $\mathbf{4 0 0} \mathrm{min}$ of testing were used to analyze 


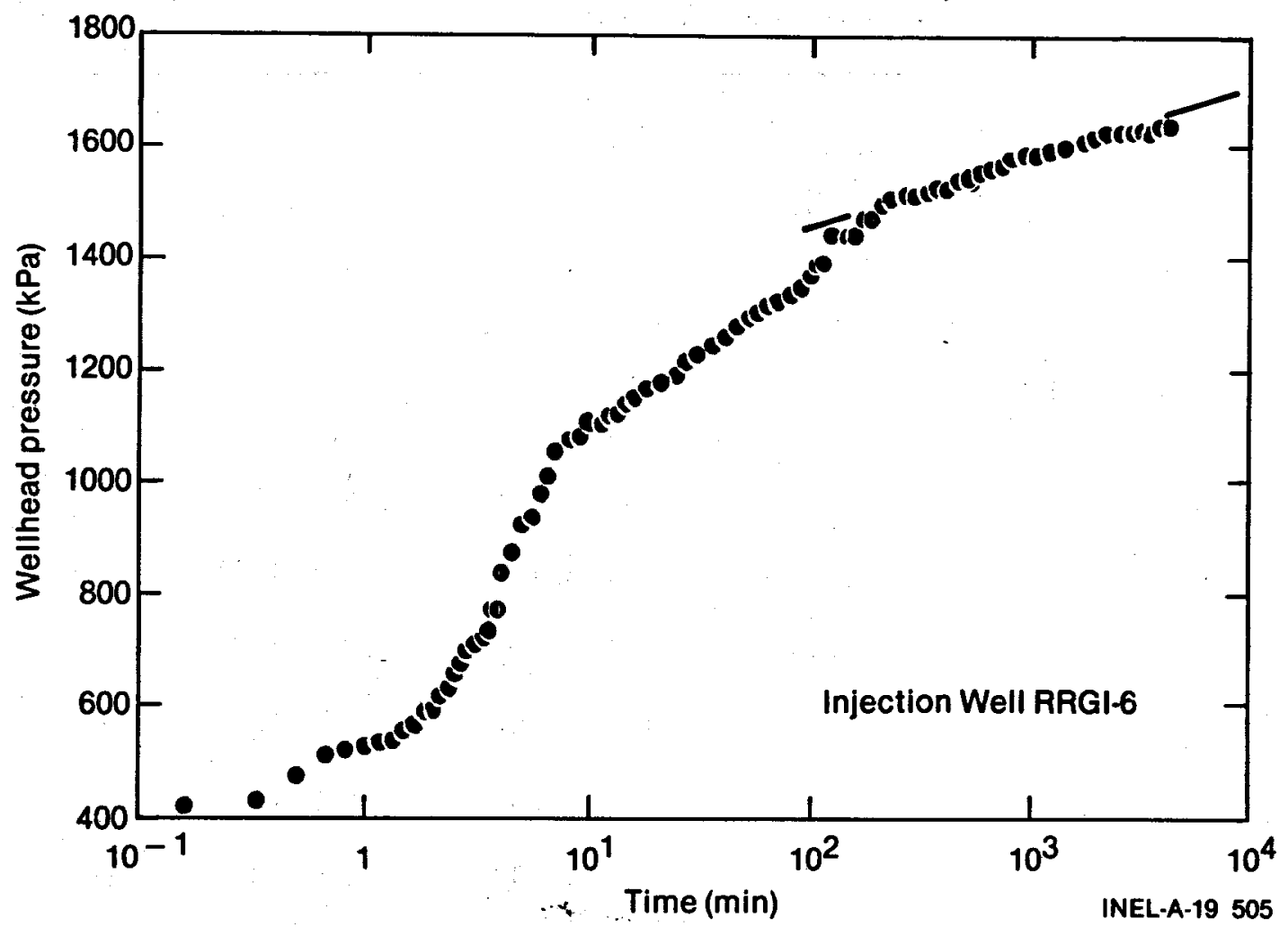

Figure 63. Pressure buildup during injection test of well RRGI-6, January 10-13, 1979. The test ran for 72 hours at an injection rate of $44.2 \mathrm{~L} / \mathrm{s}$. Data collected at the wellhead.

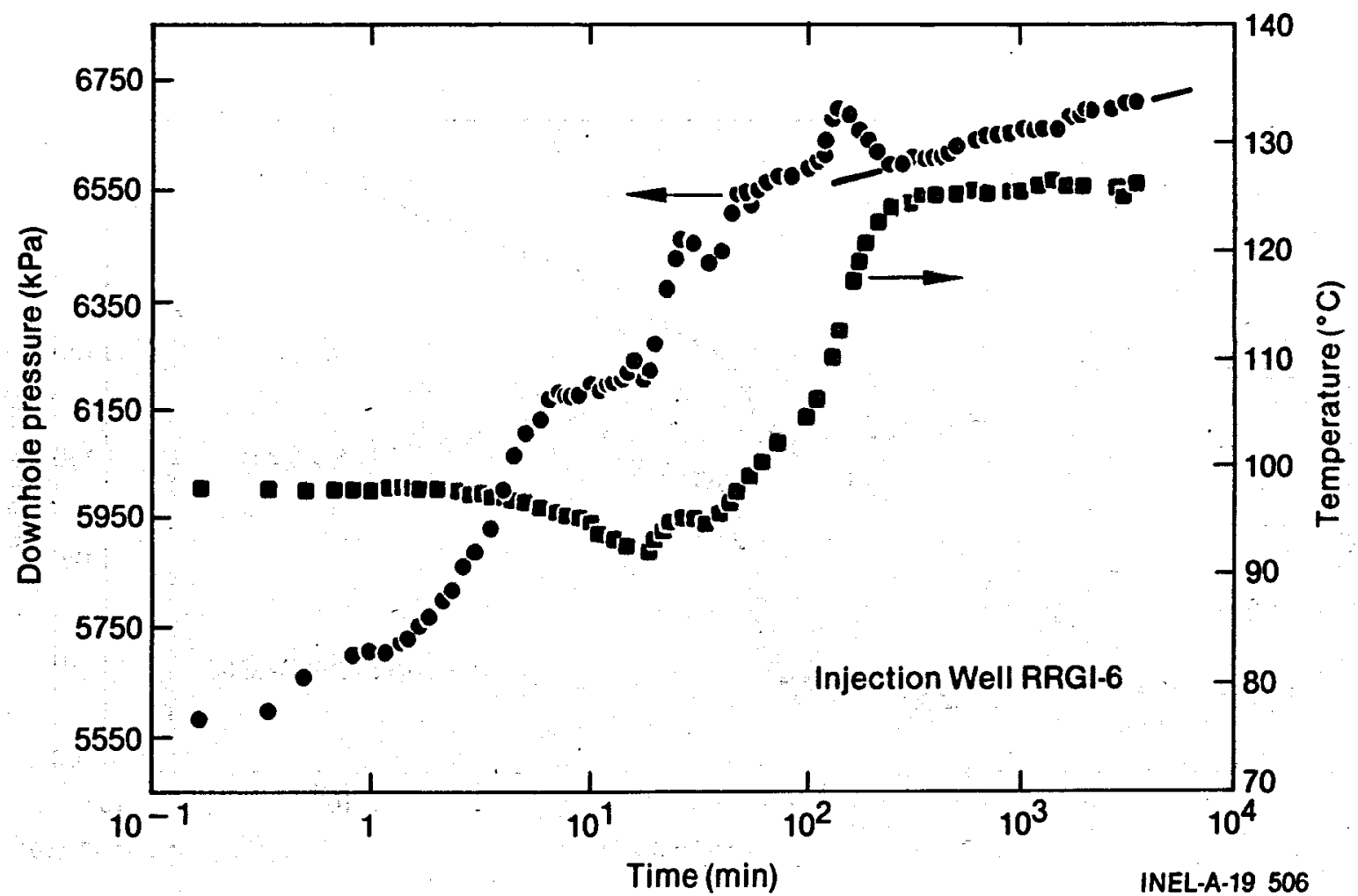

Figure 64. Pressure buildup and water temperature during injection test of well RRGI-6, January 10-13, 1979. The test ran for 72 hours at an injection rate of $44.2 \mathrm{~L} / \mathrm{s}$. Data collected at $610 \mathrm{~m}$. 
Table 26. Summary of well parameters at RRGI-6

\begin{tabular}{|c|c|c|c|c|c|}
\hline Date & $\begin{array}{c}Q \\
(L / S) \\
\end{array}$ & $\begin{array}{c}Q / s_{10} \\
(\mathrm{~L} / \mathrm{s} / \mathrm{kPa}) \\
\end{array}$ & $\begin{array}{r}\mathrm{kH} \\
(\mathrm{mD} \cdot \mathrm{m}) \\
\end{array}$ & $\begin{array}{c}T_{a} \\
\left(m^{2} / s\right) \\
\end{array}$ & Type \\
\hline 01/10/79 & 44.2 & 0.39 & $1.6 \times 10^{4}$ & $2.1 \times 10^{-4}$ & $\begin{array}{l}\text { Injection } \\
\text { (wellhead) }\end{array}$ \\
\hline $01 / 10 / 79$ & 44.2 & 0.40 & $1.7 \times 10^{4}$ & $2.1 \times 10^{-4}$ & $\begin{array}{l}\text { Injection } \\
(610 \mathrm{~m})\end{array}$ \\
\hline $03 / 10 / 79$ & 37.8 & 0.34 & $1.4 \times 10^{4}$ & $1.8 \times 10^{-4}$ & Injection \\
\hline $03 / 10 / 79$ & 37.8 & 0.27 & $1.1 \times 10^{4}$ & $1.4 \times 10^{-4}$ & Recovery \\
\hline $05 / 16 / 79$ & 40.4 & 0.34 & $1.4 \times 10^{4}$ & $1.8 \times 10^{-4}$ & Injection \\
\hline $05 / 16 / 79$ & 40.4 & 0.24 & $1.0 \times 10^{4}$ & $1.3 \times 10^{-3}$ & Recovery \\
\hline $05 / 14 / 80$ & 45.7 & 0.29 & $1.2 \times 10^{4}$ & $1.5 \times 10^{-4}$ & Recovery \\
\hline $08 / 19 / 80$ & 56.8 & 0.28 & $1.2 \times 10^{4}$ & $1.5 \times 10^{-4}$ & Injection \\
\hline $.08 / 19 / 80$ & 56.8 & 0.24 & $1.0 \times 10^{4}$ & $1.3 \times 10^{-4}$ & Recovery \\
\hline
\end{tabular}

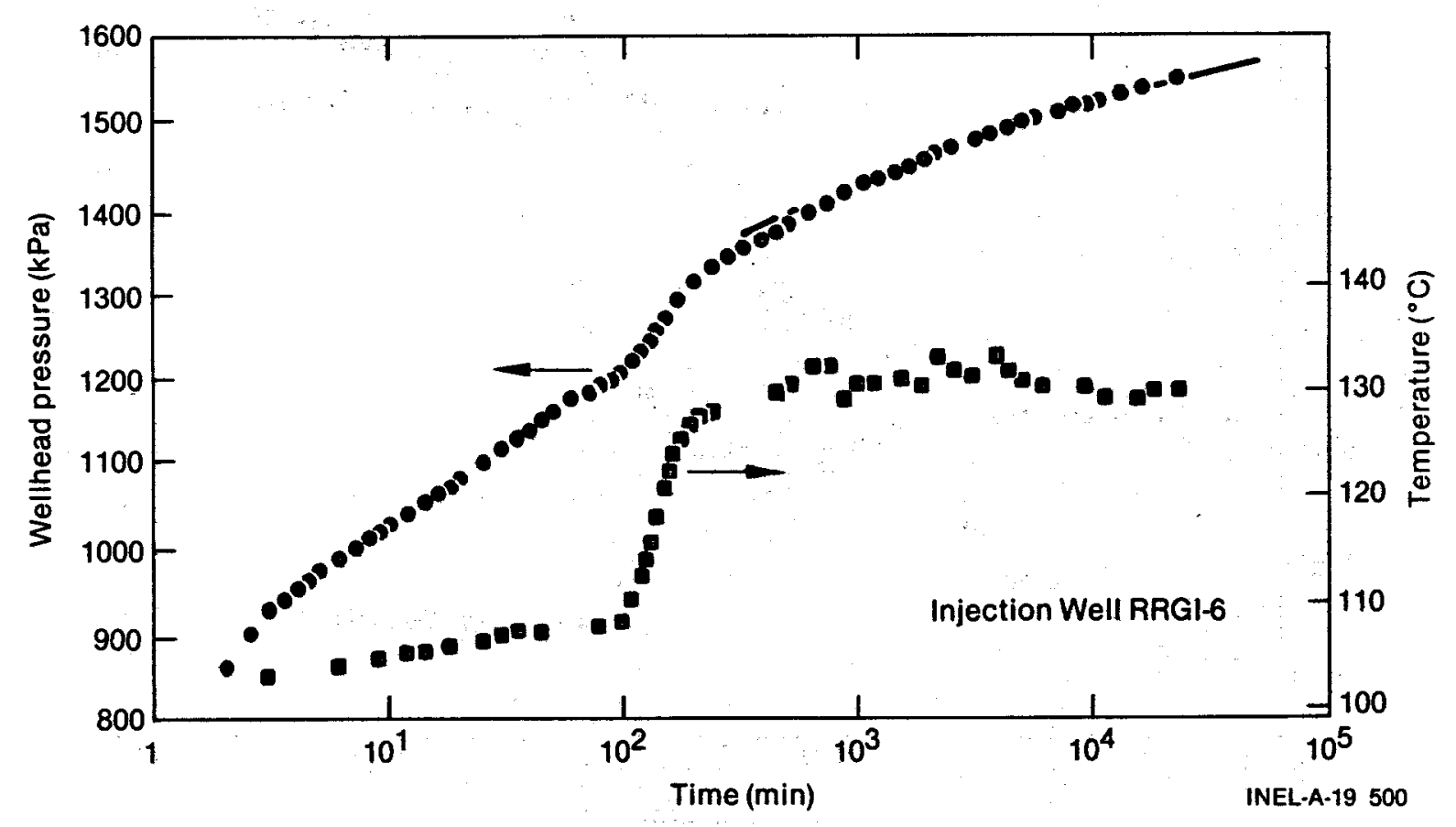

Figure 65. Pressure buildup and temperature during injection test of well RRGI-6, March 10-31, 1979. Test duration was 504 hours at an injection rate of $37.8 \mathrm{~L} / \mathrm{s}$. 


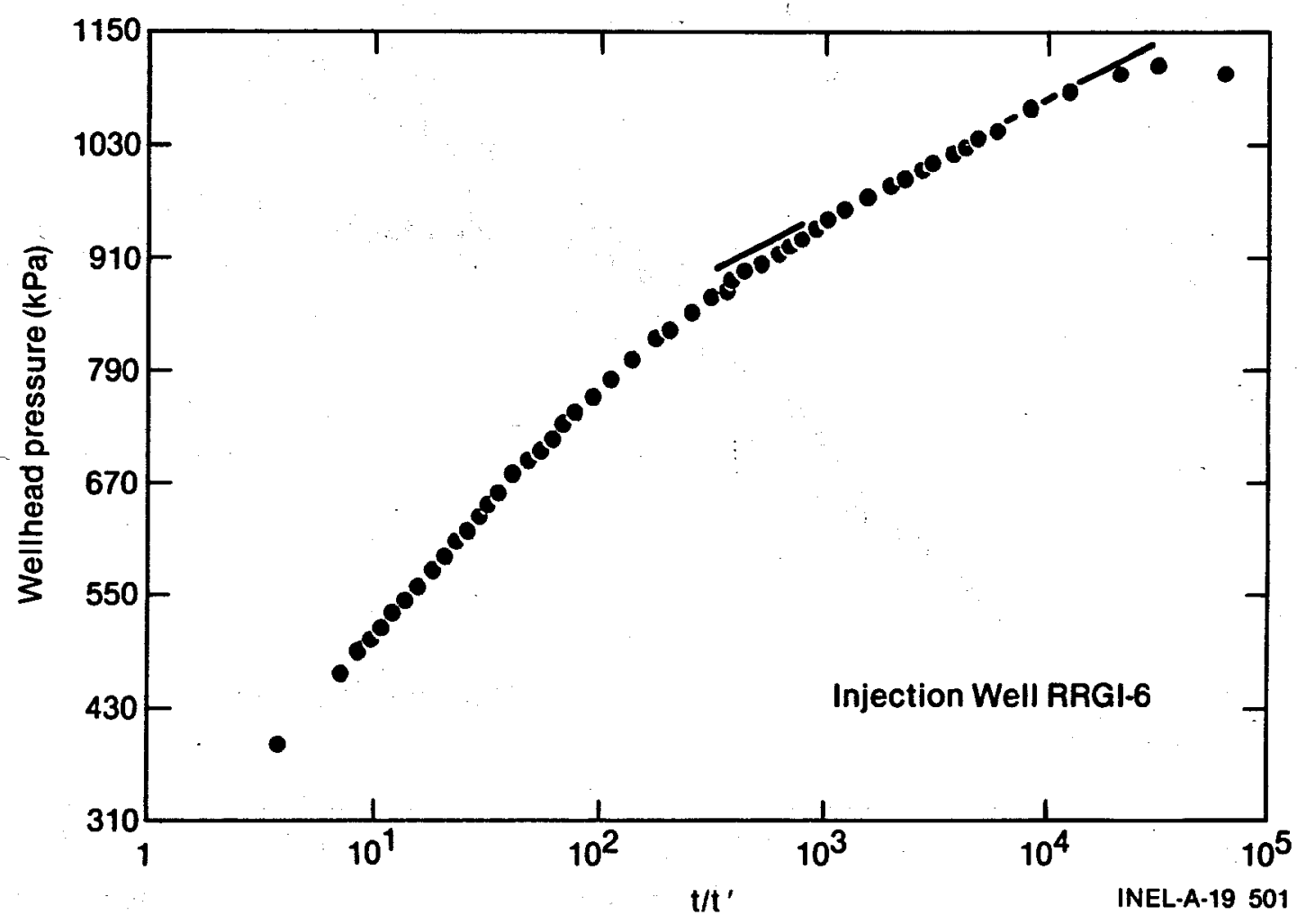

Figure 66. Pressure decline during recovery after injection test of well RRGI-6, August 10-31, 1979. Injection rate for $37.8 \mathrm{~L} / \mathrm{s}$ for 504 hours.

aquifer characteristics. Early recovery data were used to analyze for aquifer properties, to minimize thermal effects as standing water in the wellbore cools. Aquifer parameters calculated for the injection phase are: $\mathrm{Q} / \mathrm{s}_{10}=0.34(\mathrm{~L} / \mathrm{s}) /(\mathrm{kPa}) / \log$ cycle, $\mathrm{kH}_{\mathrm{a}}-14000 \mathrm{mD} \cdot \mathrm{m}$, and $\mathrm{T}_{\mathrm{a}}=1.8 \times 10^{-4} \mathrm{~m}^{2} / \mathrm{s}$. For the recovery phase, the parameters are: $\mathrm{Q} / \mathrm{s}_{10}=0.27(\mathrm{~L} / \mathrm{s}) /(\mathrm{kPa}) / \log$ cycle, $\mathrm{kH}_{\mathrm{a}}=11000 \mathrm{mD} \cdot \mathrm{m}$, and $\mathrm{T}_{\mathrm{a}}=1.4 \mathrm{x}$ $10^{-4} \mathrm{~m}^{2} / \mathrm{s}$. These parameter estimates are summarized in Table 26 .

A second 21-day test was performed during May and June of 1979 at a flow rate of $40.4 \mathrm{~L} / \mathrm{s}$. Injection pressure buildup again showed a change in slope at about $300 \mathrm{~min}$ (Figure 67), corresponding to a stabilization in wellhead water temperature. Analysis of the data collected for the latter part of this test give the following parameter estimates: $\mathrm{Q} / \mathrm{s}_{10}=0.34, \mathrm{kH}_{2}=15000 \mathrm{mD} \cdot \mathrm{m}$, and $\mathrm{T}_{\mathrm{a}}=1.8 \times 10^{-4} \mathrm{~m}^{2} / \mathrm{s}$. Parameters estimated from the recovery phase (Figure 68) are: $\mathrm{Q} / \mathrm{s}_{10}=0.24(\mathrm{~L} / \mathrm{s}) /(\mathrm{kPa}) / \log$ cycle, $\mathrm{kH}_{\mathrm{a}}=10.000 \mathrm{mD} \cdot \mathrm{m}$, and $\mathrm{T}_{\mathrm{a}}=1.3 \times 10^{-4} \mathrm{~m}^{2} / \mathrm{s}$.

A long-duration test lasting 680 hours was run during May and June of 1980. Data collected during the injection phase of the test were, unfortunately, not suitable for analysis. Data from the recovery phase of the test are shown in Figure 69. Reservoir parameters estimated for early time recovery data are: $Q / s_{10}=$ $0.29(\mathrm{~L} / \mathrm{s}) /(\mathrm{kPa}) / \log$ cycle, $\mathrm{kH}_{\mathrm{a}}=2000 \mathrm{mD} \cdot \mathrm{m}$, and $\mathrm{T}_{\mathrm{a}}=1.5 \times 10^{-4} \mathrm{~m}^{2} / \mathrm{s}$.

A second test was run during August of 1980 . The injection rate of $56.8 \mathrm{~L} / \mathrm{s}$ is the highest rate of the injection tests considered here. Both injection (Figure 70) and recovery (Figure 71) phases of the test were analyzed. Parameters determined from injection data are: $\mathrm{Q} / \mathrm{s}_{10}=0.28(\mathrm{~L} / \mathrm{s}) /(\mathrm{kPa}) / \log$ cycle, $\mathrm{kH}_{\mathrm{a}}=$ $12000 \mathrm{mD} . \mathrm{m}$, andT $\mathrm{a}=1.5 \times 10^{-4} \mathrm{~m}^{2} / \mathrm{s}$. For the recovery phase of the test, parameter estimates are: $\mathrm{Q} / \mathrm{s}_{10}=0.24(\mathrm{~L} / \mathrm{s}) /(\mathrm{kPa}) / \log$ cycle, $\mathrm{kH}_{\mathrm{a}}=10000 \mathrm{mD} \cdot \mathrm{m}$, and $\mathrm{T}_{\mathrm{a}}=1.3 \times 10^{-4} \mathrm{~m}^{2} / \mathrm{s}$.

Table 26 summarizes all the parameter estimates obtained from the five tests on well RRGI-6. There appears to be no correlation between aquifer parameters and flow rate, which is as it should be. For injection tests there seems to be an increasing trend with time, with later injection estimates being closer to recovery test estimates. 


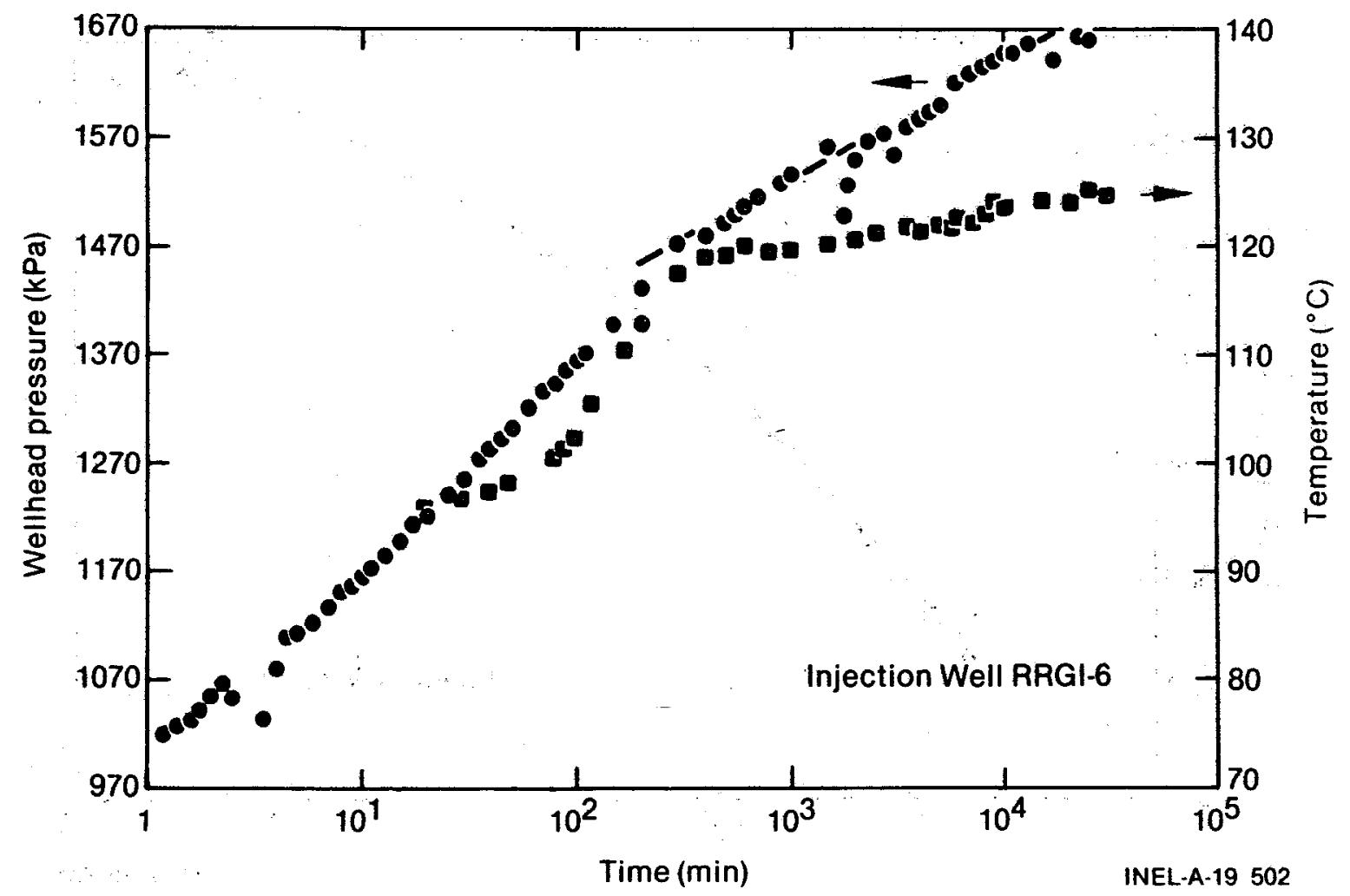

Figure 67. Pressure buildup and temperature during injection test of well RRGI-6, May 16-June 6, 1979. Test ran for 500 hours at an injection rate of $40.4 \mathrm{~L} / \mathrm{s}$.

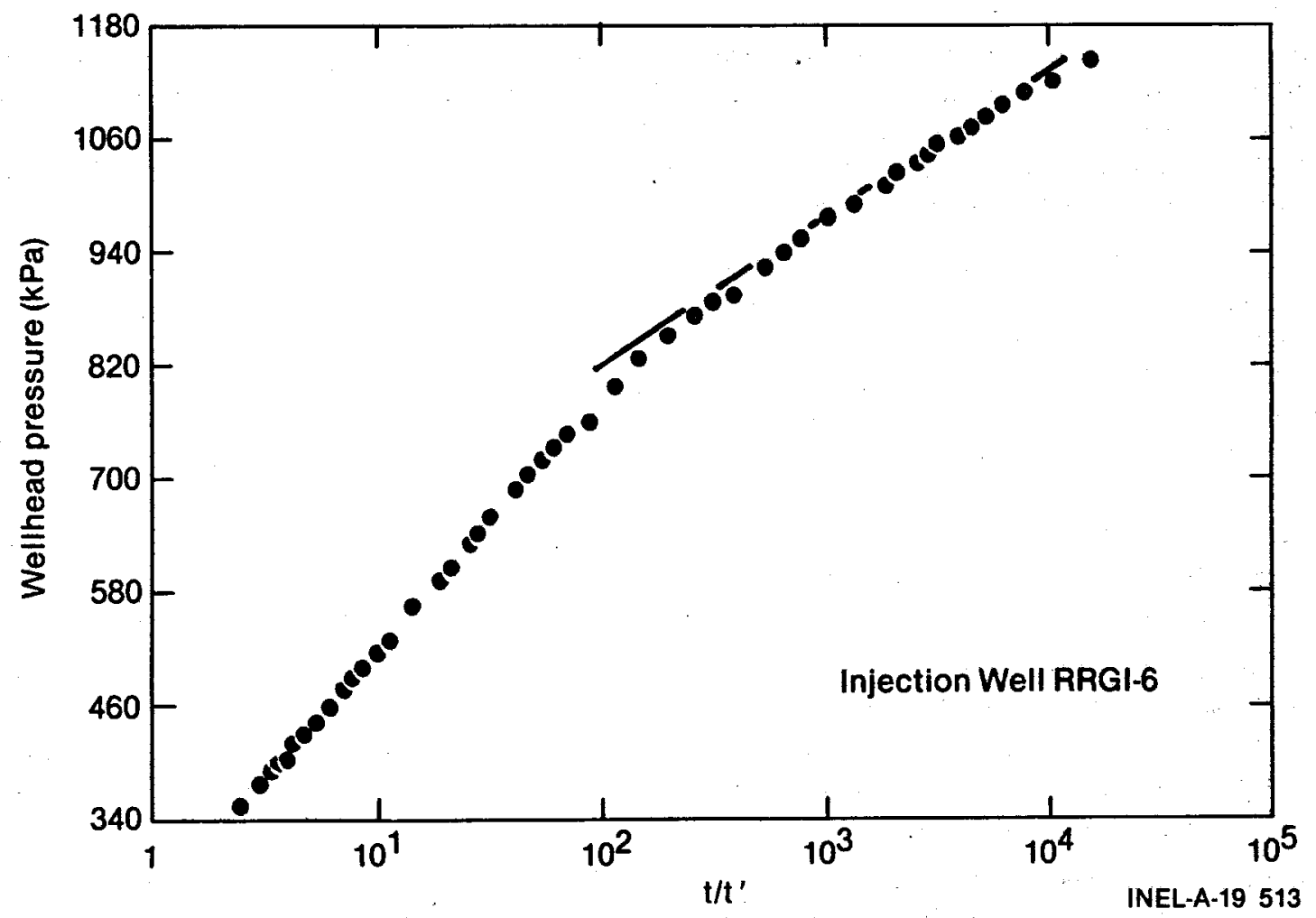

Figure 68. Pressure decline during recovery after injection test of well RRGI-6, May 16-June 6, 1979. Injection was at a rate of $40.4 \mathrm{~L} / \mathrm{s}$ for 500 hours. 


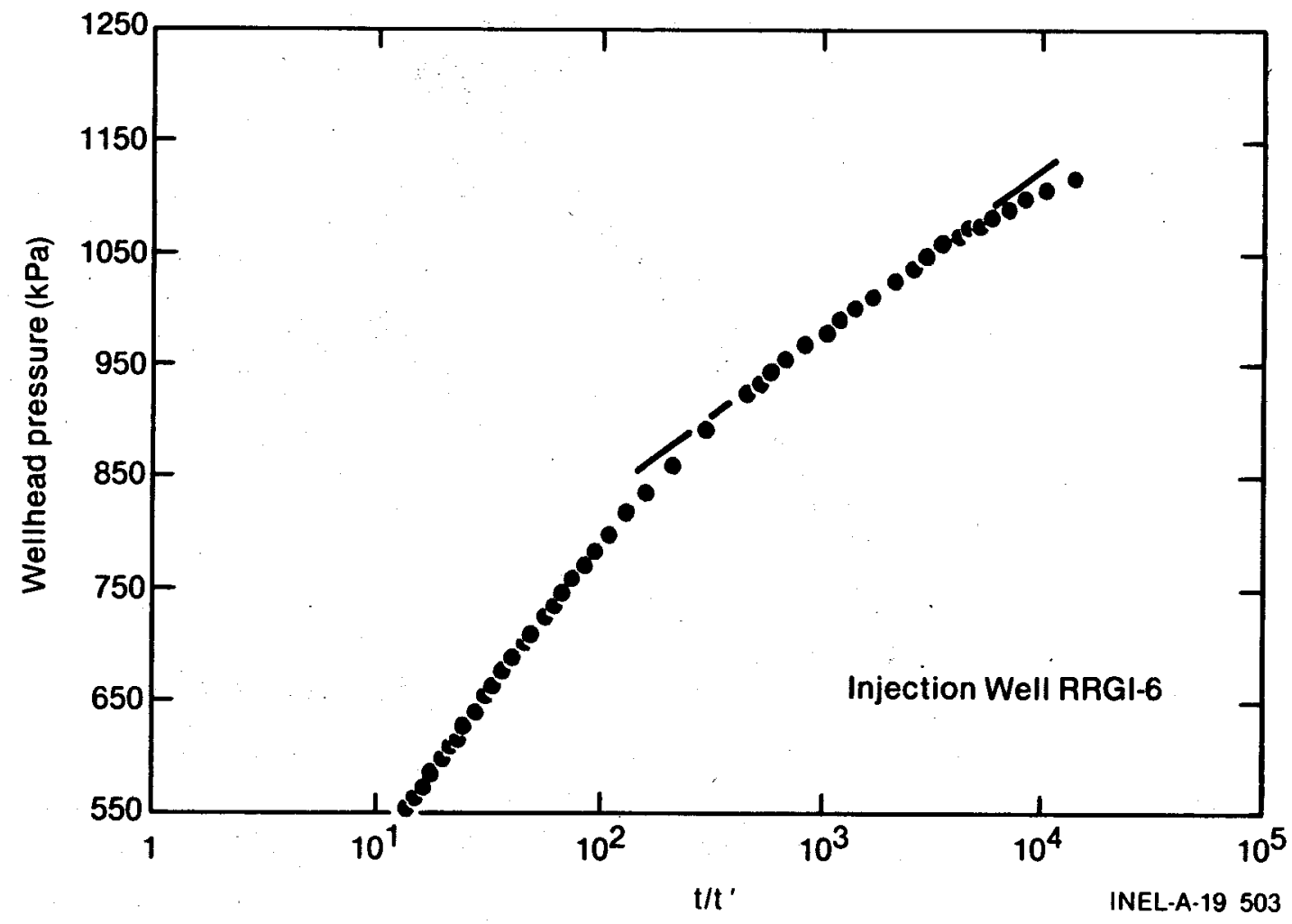

Figure 69. Pressure decline during recovery after injection test of well RRGI-6, May 14-June 11, 1980. Test ran for 680 hours at an injection rate of $45.7 \mathrm{~L} / \mathrm{s}$.

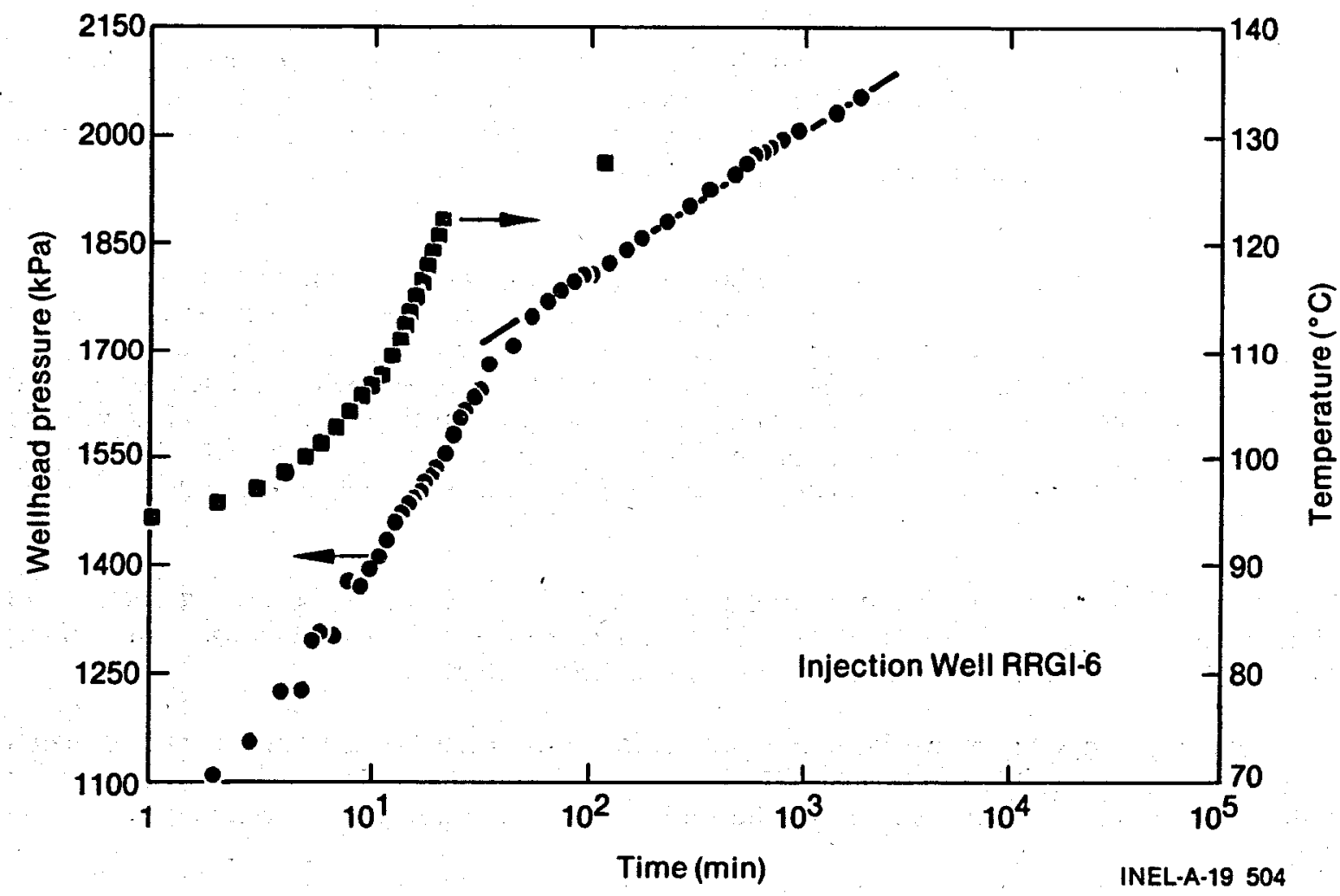

Figure 70. Pressure buildup and water temperature during injection test of well RRGI-6, August 19-28, 1980. An injection rate of $56.8 \mathrm{~L} / \mathrm{s}$ was used for 190 hours. 


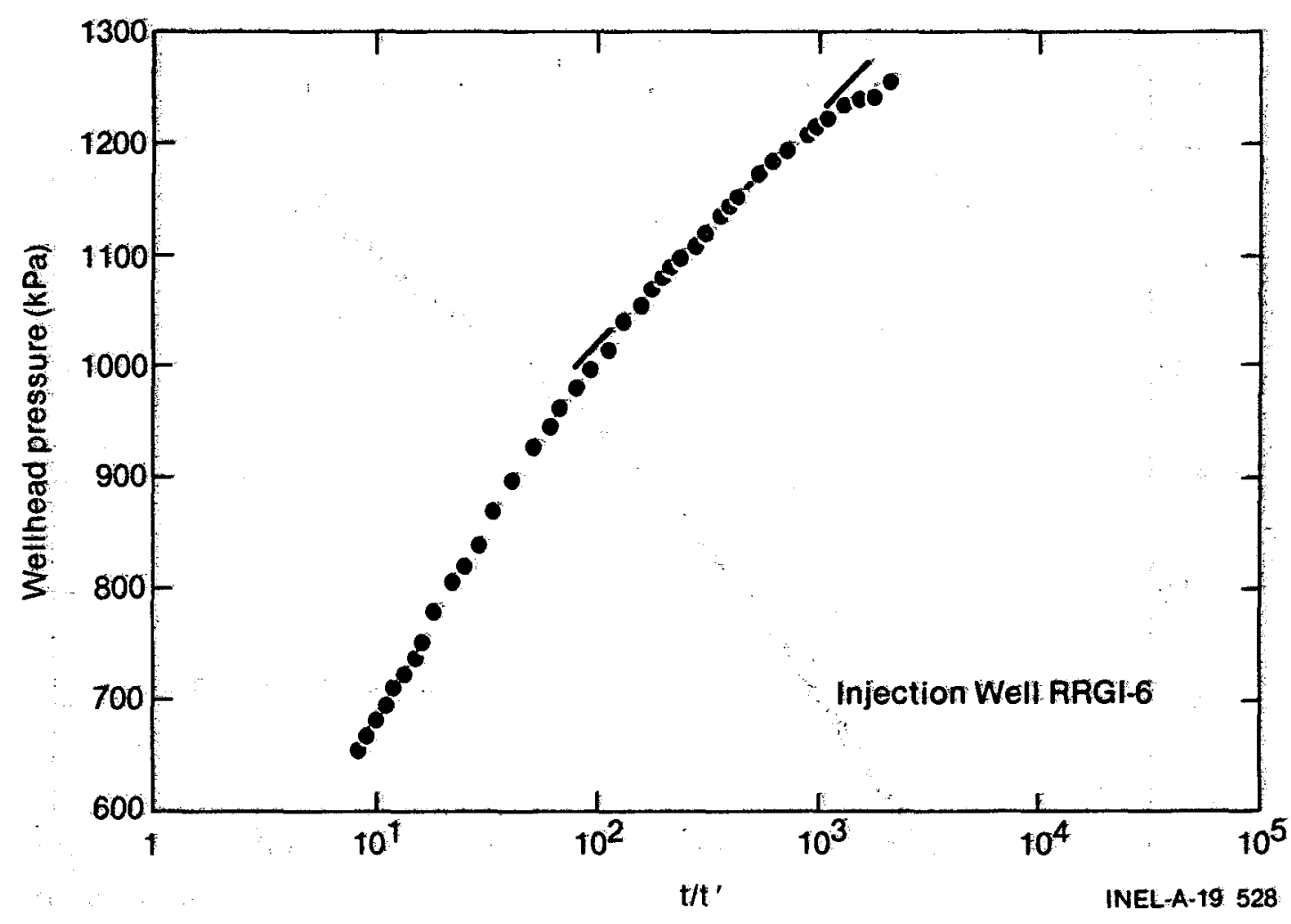

Figure 71. Pressure decline during recovery after injection test of well RRGI-6, August 19-28, 1980. The test ran for 190 hours at an injection rate of $56.8 \mathrm{~L} / \mathrm{s}$.

The 24-hour specific injectability was essentially constant for the four injection tests with values of 0.12 , $0.11,0.10$, and $0.13(\mathrm{~L} / \mathrm{s}) / \mathrm{kPa}$, in chronological order. The receptivity curve for well RRGI-6 is plotted in Figure 72. Injection rates varied over a narrow range, so the actual nature of the injectability relation cannot be determined. A linear least squares fit to the data gives the equation: pressure $=177.36+$ $0.462 \times$ discharge.

Figure 73 shows predicted wellhead pressure buildup for RRGI-6 after one and three years. The data points reflect projections from the four injection tests, and have been adjusted for an injection temperature of $66^{\circ} \mathrm{C}$. The estimated initial wellhead pressures for the three tests at the lower flow rates were on the order of 1100 to $1200 \mathrm{kPa}$, and for the test at $56.8 \mathrm{~L} / \mathrm{s}$ was $1400 \mathrm{kPa}$. In choosing the linear trend with increasing discharge or pressure buildup, it was assumed that the difference in initial wellhead pressure was responsible for the higher estimated pressures from this test. The alternative would be to assume a nonlinear change in pressure buildup with increased injection rates, which is not substantiated by the injectivity graph (Figure 72).

The interval 518 to $1172 \mathrm{~m}$ is open to injection (Appendix B, Figure B-19). During drilling, some loss of drilling fluid occurred in the intervals of 630 to $660 \mathrm{~m}$ and 915 to $975 \mathrm{~m}$. Temperature logs during drilling indicated a possible contributory zone in the intervals of 585 to $610 \mathrm{~m}$.

Available caliper logs do not provide useful information. Flow meter logs indicate that approximately two-thirds of the flow in RRGI-6 occurs in the intervals of 518 to $615 \mathrm{~m}$. The major injection zone in RRGI- 6 occurs in the $100-\mathrm{m}$ interval of open borehole immediately below the $34-\mathrm{cm}$ casing from 518 to $615 \mathrm{~m}$.

4.5.7 Well RRGI-7. A list of five well tests run on well RRGI-7 for which data was suitable for analysis is shown in Table 27. In August 1979, a series of short tests were run ranging in length from less than 1 hour 


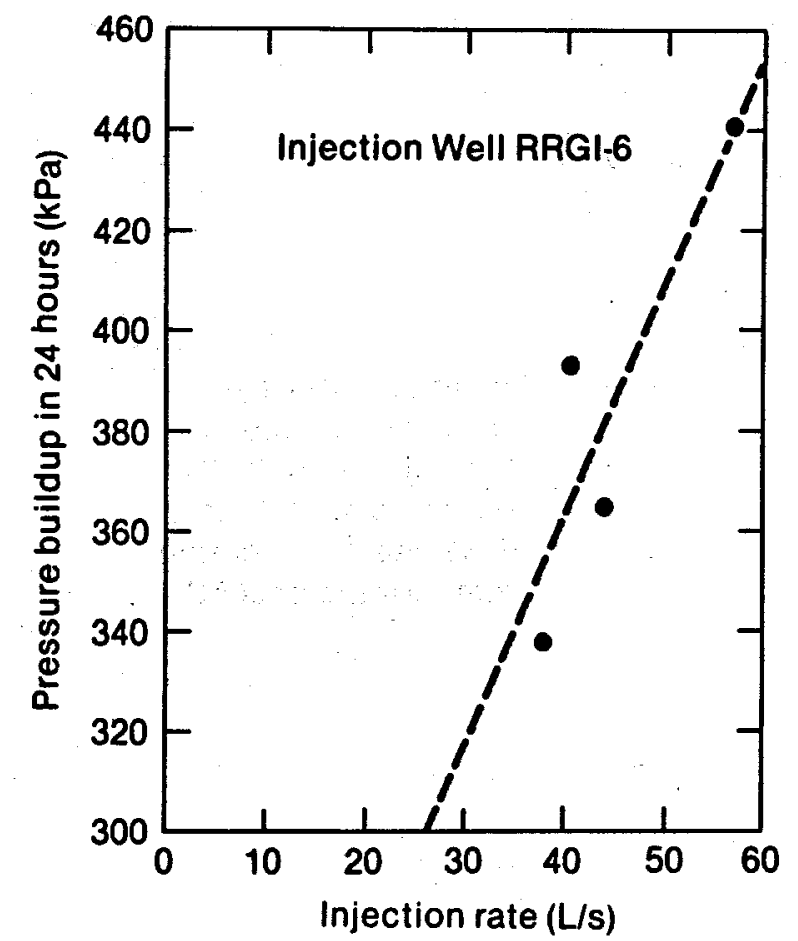

INEL-A-19 527

Figure 72. Injectivity curve of 24-hour data from injection well RRGI-6.

to 96 hours. An 8-hour test and the 96-hour test were analyzed to determine aquifer properties. Both injection and recovery phases of these tests were monitored; and for the 96-hour test, downhole temperature and pressure was monitored. Figure 74 is a plot of wellhead pressure and temperature for the 8-hour test run at $39.1 \mathrm{~L} / \mathrm{s}$. Temperature stabilized at $130^{\circ} \mathrm{C}$ after $300 \mathrm{~min}$, and data from the straight-line segment after this time were analyzed. For recovery from this test (Figure 75), cooling of water in the wellbore produces a curvature in the recovery plot. Early recovery data were analyzed for reservoir parameters. Estimates of these parameters were, for injection: $Q / s_{10}=0.50(\mathrm{~L} / \mathrm{s}) /(\mathrm{kPa}) / \log$ cycle, $\mathrm{kH}_{\mathrm{a}}=2.1 \times$ $10^{4} \mathrm{mD} . \mathrm{m}$, and $\mathrm{T}_{\mathrm{a}}=2.6 \times 10^{-4} \mathrm{~m}^{2} / \mathrm{s}$, and for recovery: $\mathrm{Q} / \mathrm{s}_{10}=0.35(\mathrm{~L} / \mathrm{s}) /(\mathrm{kPa}) / \log$ cycle, $\mathrm{kH}_{\mathrm{a}}=$ $1.5 \times 10^{4} \mathrm{mD} . \mathrm{m}$, and $\mathrm{T}_{\mathrm{a}}=1.9 \times 10^{-4} \mathrm{~m}^{2} / \mathrm{s}$.

Injection and recovery phases of the 96-hour test beginning on August 1, 1979 were analyzed for reservoir parameters, both at the wellhead and at a depth of $1130 \mathrm{~m}$. Analysis of the late-time wellhead injection pressures, after temperature stabilization at about $500 \mathrm{~min}$ (Figure 76), gives the following estimates for this $28.4-\mathrm{L} / \mathrm{s}$ injection test: $\mathrm{Q} / \mathrm{s}_{10}=0.48(\mathrm{~L} / \mathrm{s}) /(\mathrm{kPa}) / \log$ cycle, $\mathrm{kH}_{\mathrm{a}}=2.0 \times 10^{4} \mathrm{mD} . \mathrm{m}$, and $\mathrm{T}_{\mathrm{a}}=2.6 \mathrm{x}$ $10^{-4} \mathrm{~m}^{2} / \mathrm{s}$. The recovery phase (Figure 77) yielded the following estimates: $\mathrm{Q} / \mathrm{s}_{10}=0.33(\mathrm{~L} / \mathrm{s}) /(\mathrm{kPa}) / \log$ cycle, $\mathrm{kH}_{\mathrm{a}}=1.4 \times 10^{4} \mathrm{mD} . \mathrm{m}, \mathrm{T}_{\mathrm{a}}=1.7 \times 10^{-4} \mathrm{~m}^{2} / \mathrm{s}$. The downhole pressure data (Figure 78) exhibit a sharp break at $10 \mathrm{~min}$, with recovery between 200 and 1,000 min. Some of this behavior is attributable to temperature fluctuations. The early time data from this test were analyzed because of the uncertainty in later time data. Parameter estimates are: $\mathrm{Q} / \mathrm{s}_{10}=0.59(\mathrm{~L} / \mathrm{s}) /(\mathrm{kPa}) / \log$ cycle, $\mathrm{kH}_{\mathrm{a}}=2.5 \times 10^{4} \mathrm{mD} . \mathrm{m}$, and $T_{a}=3.1 \times 10^{-4} \mathrm{~m}^{2} / \mathrm{s}$. Analysis of the recovery data from the downhole (Figure 79) probe yields: $\mathrm{Q} / \mathrm{s}_{10}=0.37(\mathrm{~L} / \mathrm{s}) /(\mathrm{kPa}) / \log$ cycle, $\mathrm{kH}_{\mathrm{a}}=1.6 \times 10^{4} \mathrm{mD} . \mathrm{m}$, and $\mathrm{T}_{\mathrm{a}}=2.0 \times 10^{-4} \mathrm{~m}^{2} / \mathrm{s}$.

In September 1979, an 80-hour injection test was performed at a rate of $63 \mathrm{~L} / \mathrm{s}$. Temperature stabilized at $130^{\circ} \mathrm{C}$ after $200 \mathrm{~min}$. Analysis of wellhead pressure changes versus time (Figure 80) yielded the following. reservoir parameter estimates: $\mathrm{Q} / \mathrm{s}_{10}=0.75(\mathrm{~L} / \mathrm{s}) /(\mathrm{kPa}) / \log$ cycle, $\mathrm{kH}_{\mathrm{a}}=3.2 \times 10^{4} \mathrm{mD} . \mathrm{m}$, and $\mathrm{T}_{\mathrm{a}}=$ $4.0 \times 10^{-4} \mathrm{~m}^{2} / \mathrm{s}$. 


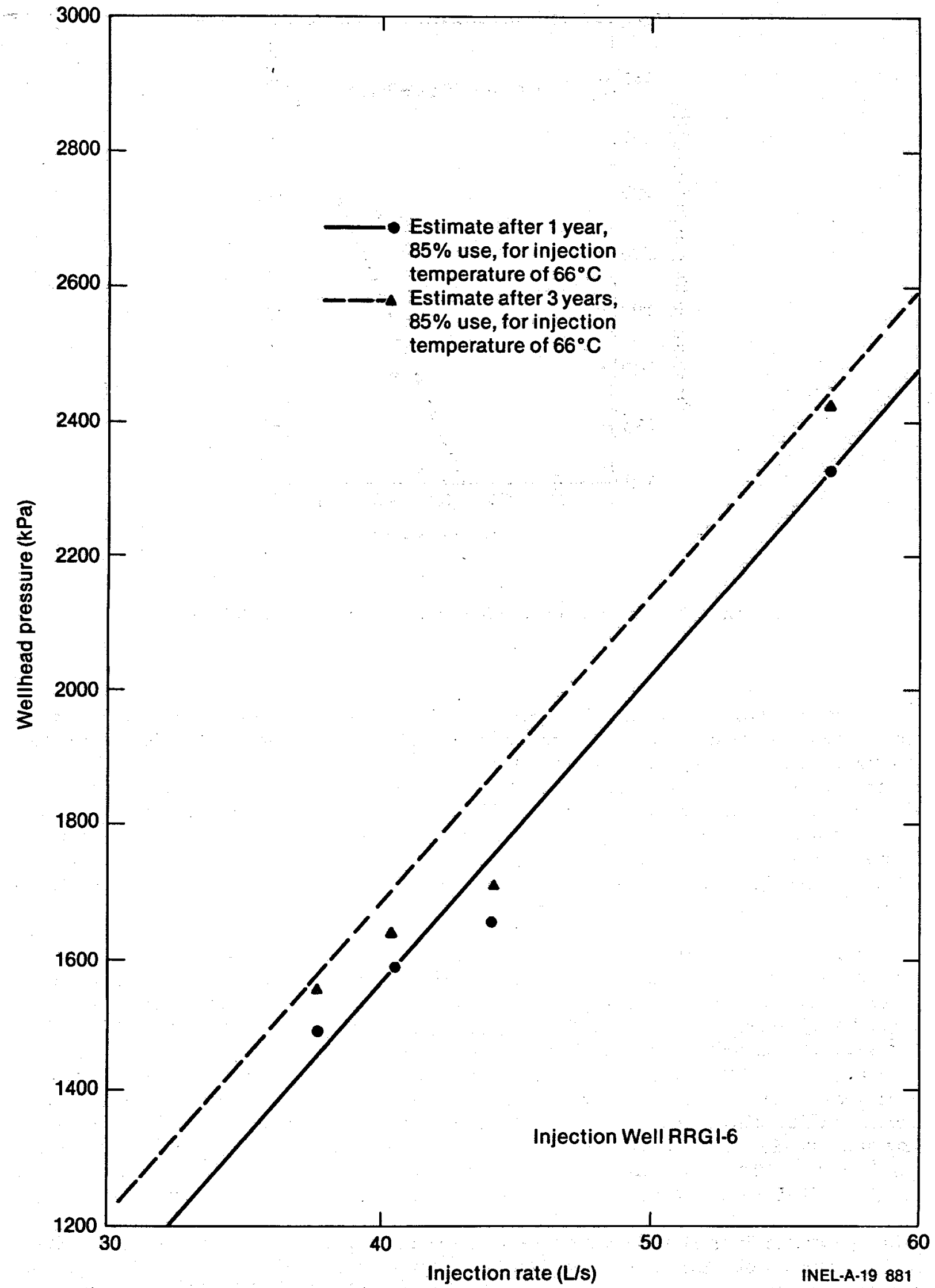

Figure 73. Predicted pressure buildup versus injection rate for injection well RRGI-6. 
Table 27. Well RRGI-7 performance testing activity

\begin{tabular}{lccccc}
\hline \multicolumn{1}{c}{ Description } & Date & $\begin{array}{c}\text { Duration } \\
(\mathrm{hr})\end{array}$ & $\begin{array}{l}\text { Rate } \\
\text { (L/s) }\end{array}$ & \multicolumn{1}{c}{ Type } \\
\cline { 1 - 3 } From RRGE-2 to RRGI-6 & $08 / 10 / 79$ & 8 & 39.1 & Injection/Recovery \\
From RRGE-2 to RRGI-6 & $08 / 11 / 79$ & 96 & 28.4 & Injection/Recovery \\
From RRGE-1 to RRGI-7 & $10 / 15 / 79$ & 80 & 63.0 & Injection \\
From RRGE-1 to RRGI-7 & $08 / 19 / 80$ & 35 & 60.0 & Injection/Recovery \\
From RRGE-1 to RRGI-7 & $09 / 10 / 80$ & 285 & 56.8 & Recovery \\
\hline
\end{tabular}

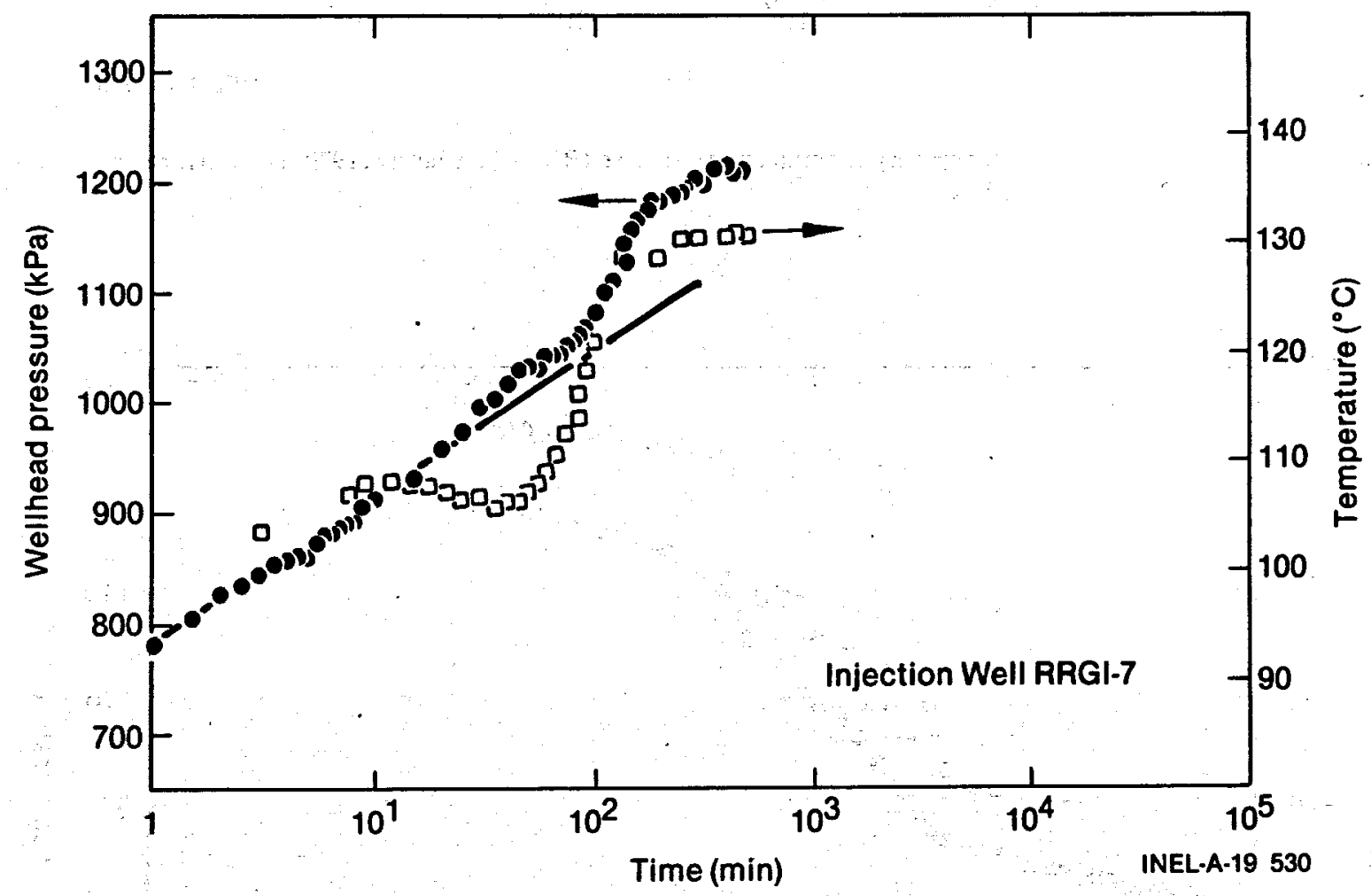

Figure 74. Pressure buildup and water temperature during injection test of well RRGI-7, August 8, 1979 at an injection rate of $39.1 \mathrm{~L} / \mathrm{s}$ for 8 hours.

During August and September of 1980 , pumping activity was designed to check pumps, pipelines, and the $5 \mathrm{MW}(\mathrm{e})$ power plant. For two of these tests, sufficient data were gathered for reservoir evaluation. Between mid-August and mid-September, well RRGE-1 was pumped into either well RRGI-6 or well RRGI-7. Starting August 19, 1980,60 L/s was injected into RRGI-7. However, after 35 hours, trouble with the pump at RRGI-7 necessitated switching injection to RRGI-6. Injection into RRGI-6 continued until August 28, when injection was switched back to RRGI-7. Injection at RRGI-7 continued until September 10. Both the injection and recovery phases of the 35-hour test on August 19 were analyzed. Only the data from the recovery phase of the 285 -hour test were suitable for analysis. 


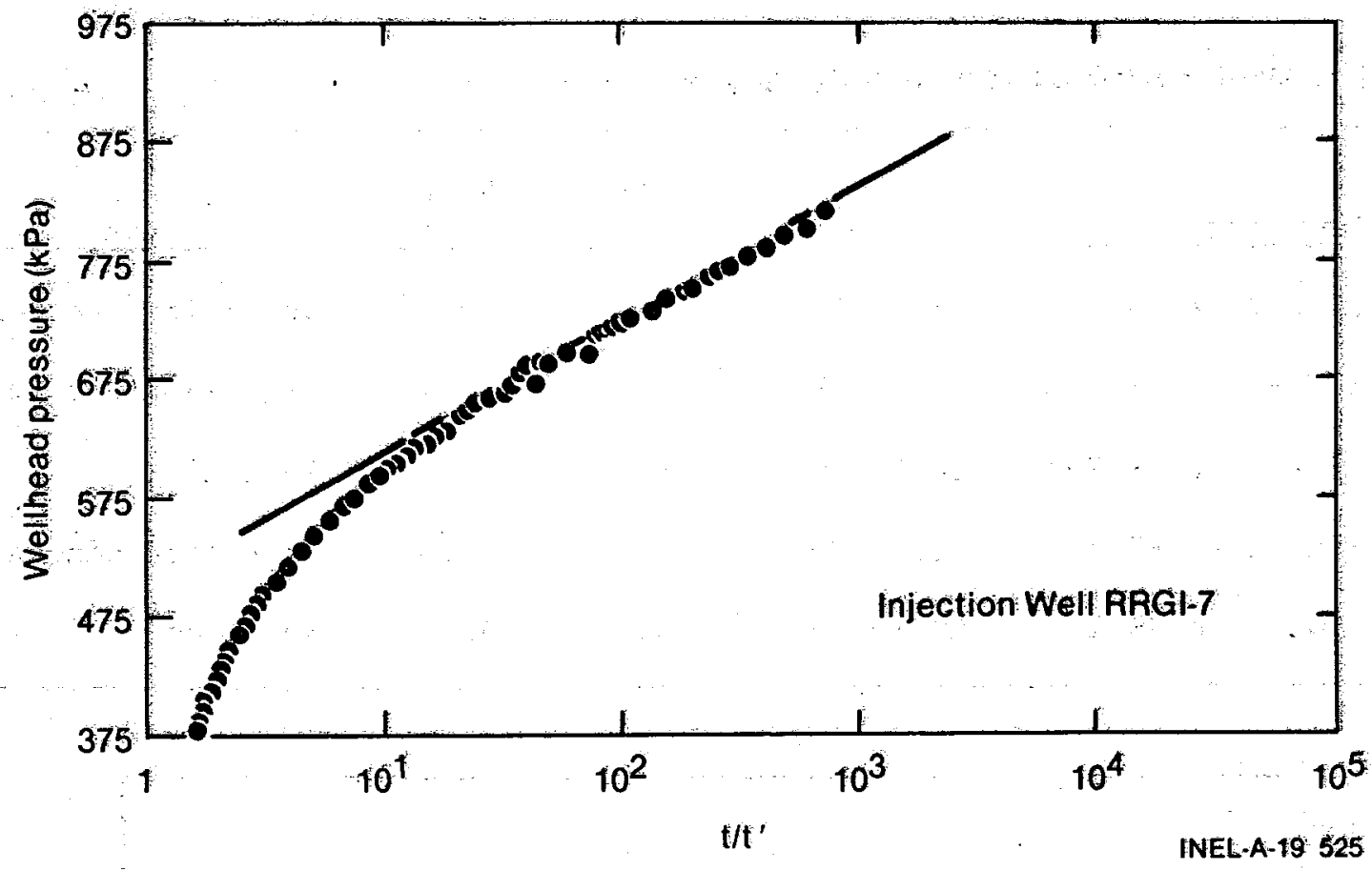

Figure 75. Pressure decline during recovery after injection test of well RRGI-7, August 8, 1979. Test tan for 8 hoursat an injection rate of $39.1 \mathrm{~L} / \mathrm{s}$.

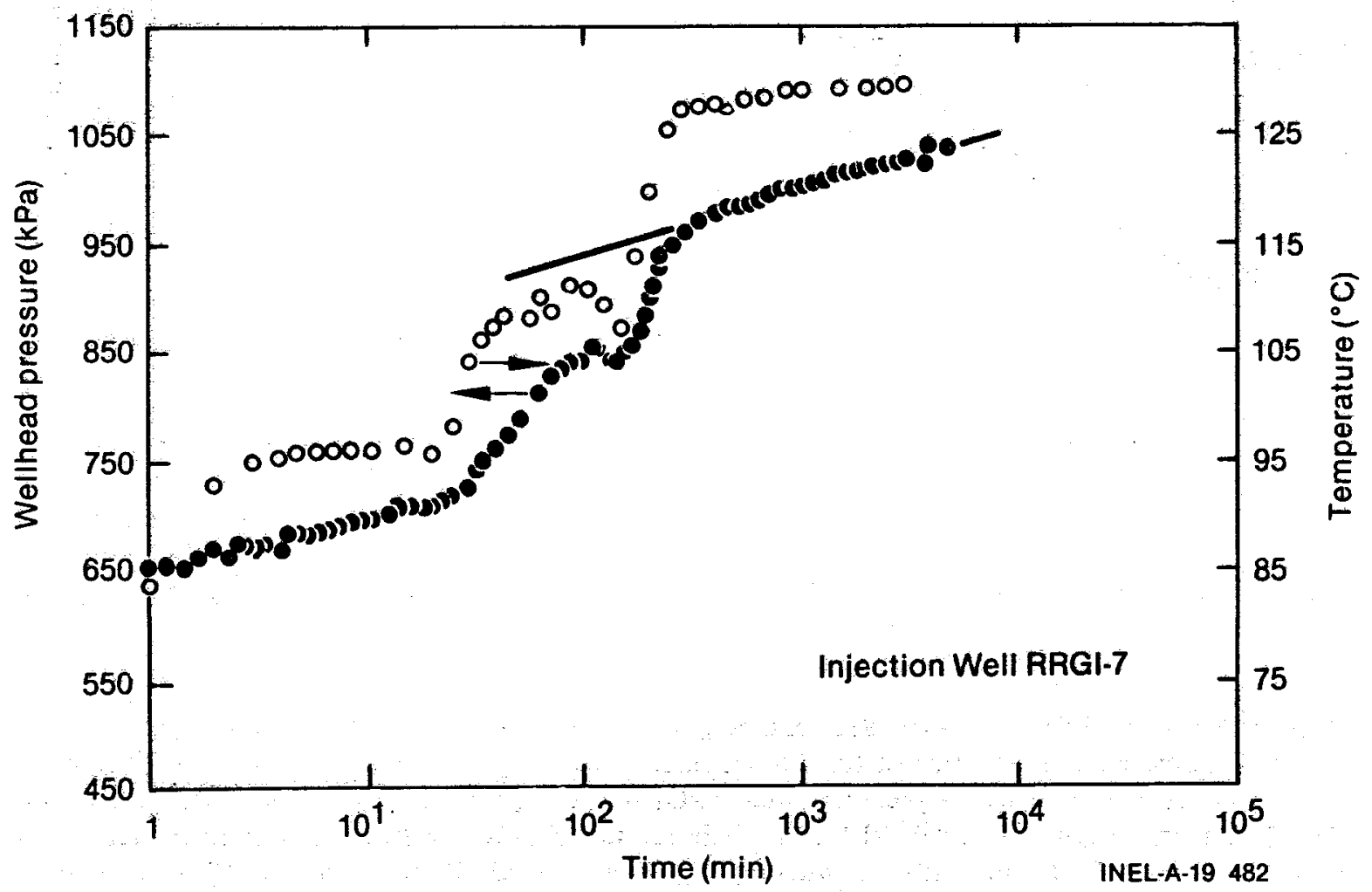

Figure 76. Pressure buildup and water temperature during injection test of well RRGI-7, August 11-15, 1979. Test duration was 96 hours at an injection rate of $28.4 \mathrm{~L} / \mathrm{s}$. Data collected at the welihead. 


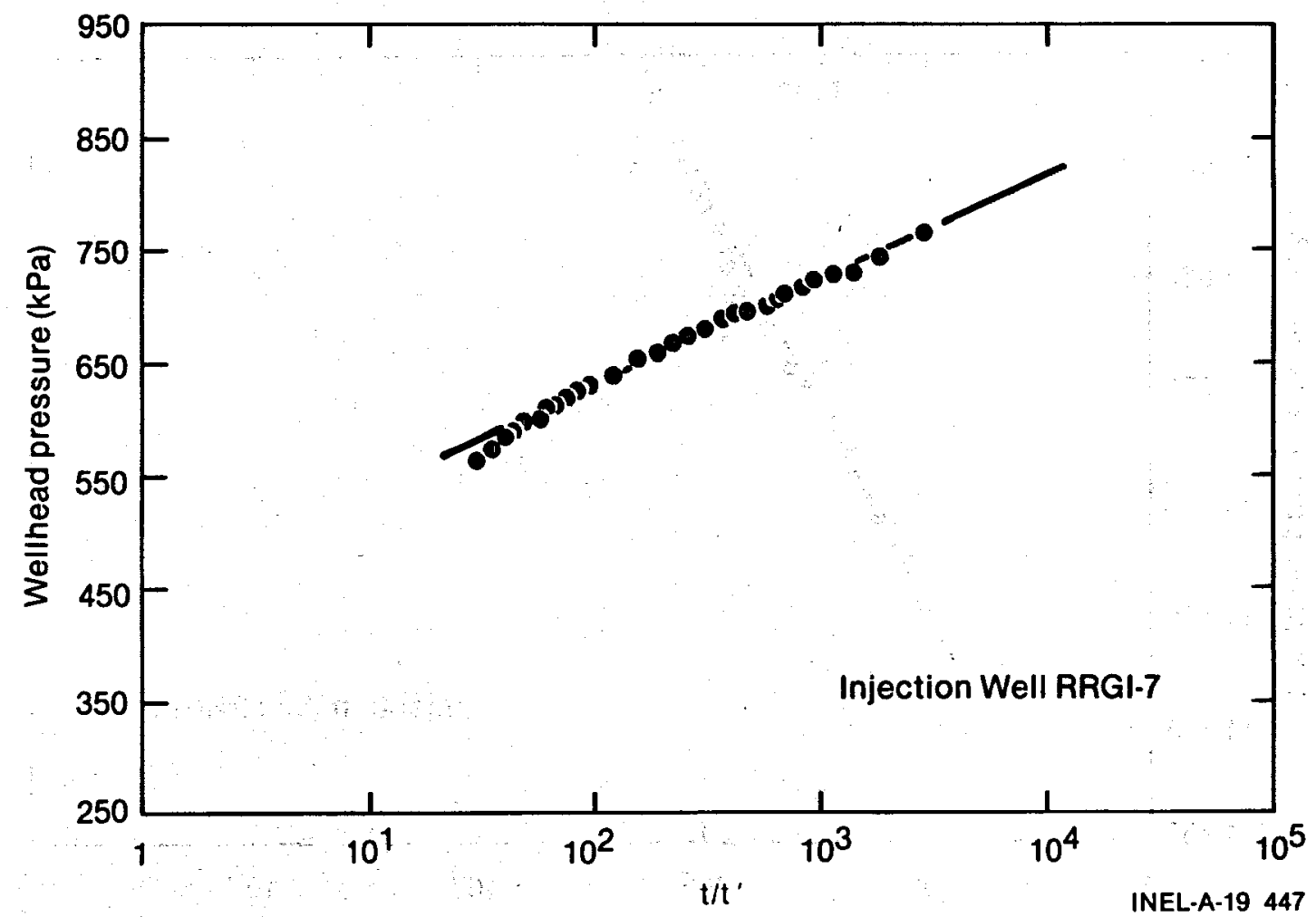

Figure 77. Pressure decline during recovery after injection test of well RRGI-7, Augusi 11-15, 1979. Test ran for 96 hours at an injection rate of $28.4 \mathrm{~L} / \mathrm{s}$. Data collected at the wellhead.

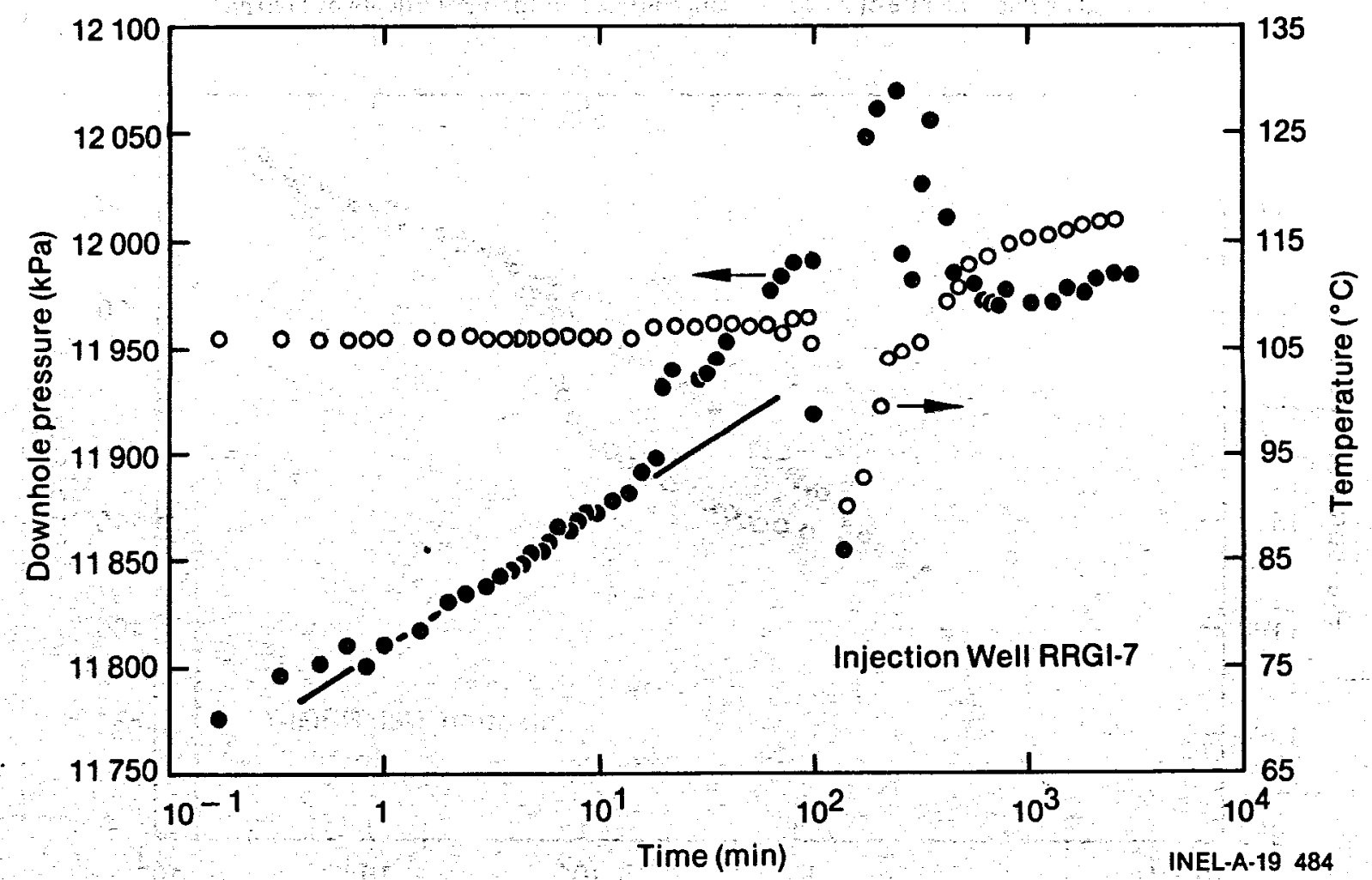

Figure 78. Pressure buildup and temperature during injection test of well RRGI-7, August 11-15, 1979. Test duration was 96 hours at an injection rate of $28.4 \mathrm{~L} / \mathrm{s}$. Data collected downhole at a depth of $1130 \mathrm{~m}$. 


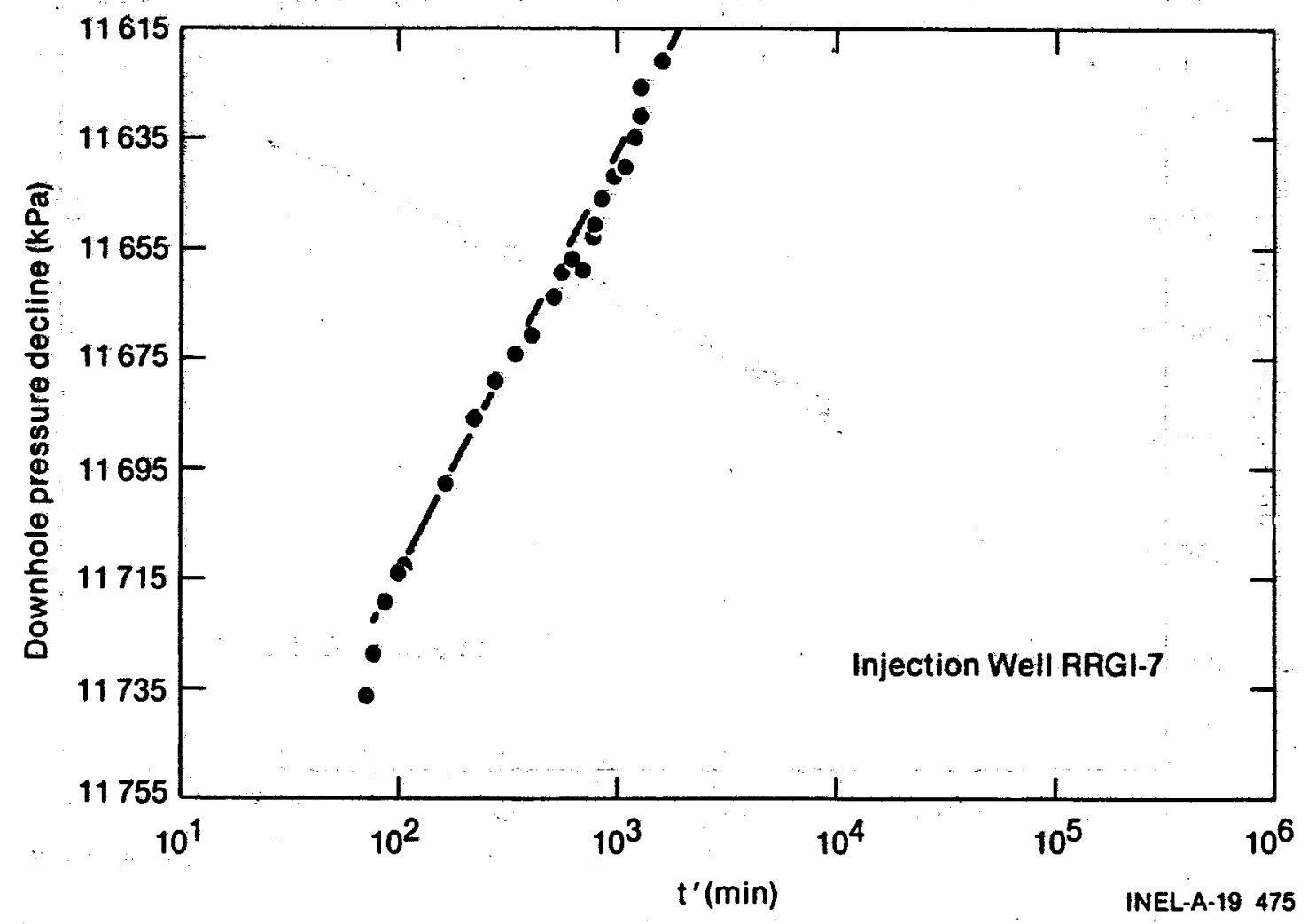

Figure 79. Pressure decline during recovery after injection test of well RRGI-7, August 11-15, 1979. Test ran for 96 hours at an injection rate of $28.4 \mathrm{~L} / \mathrm{s}$. Data collected downhole at a depth of $1130 \mathrm{~m}$.

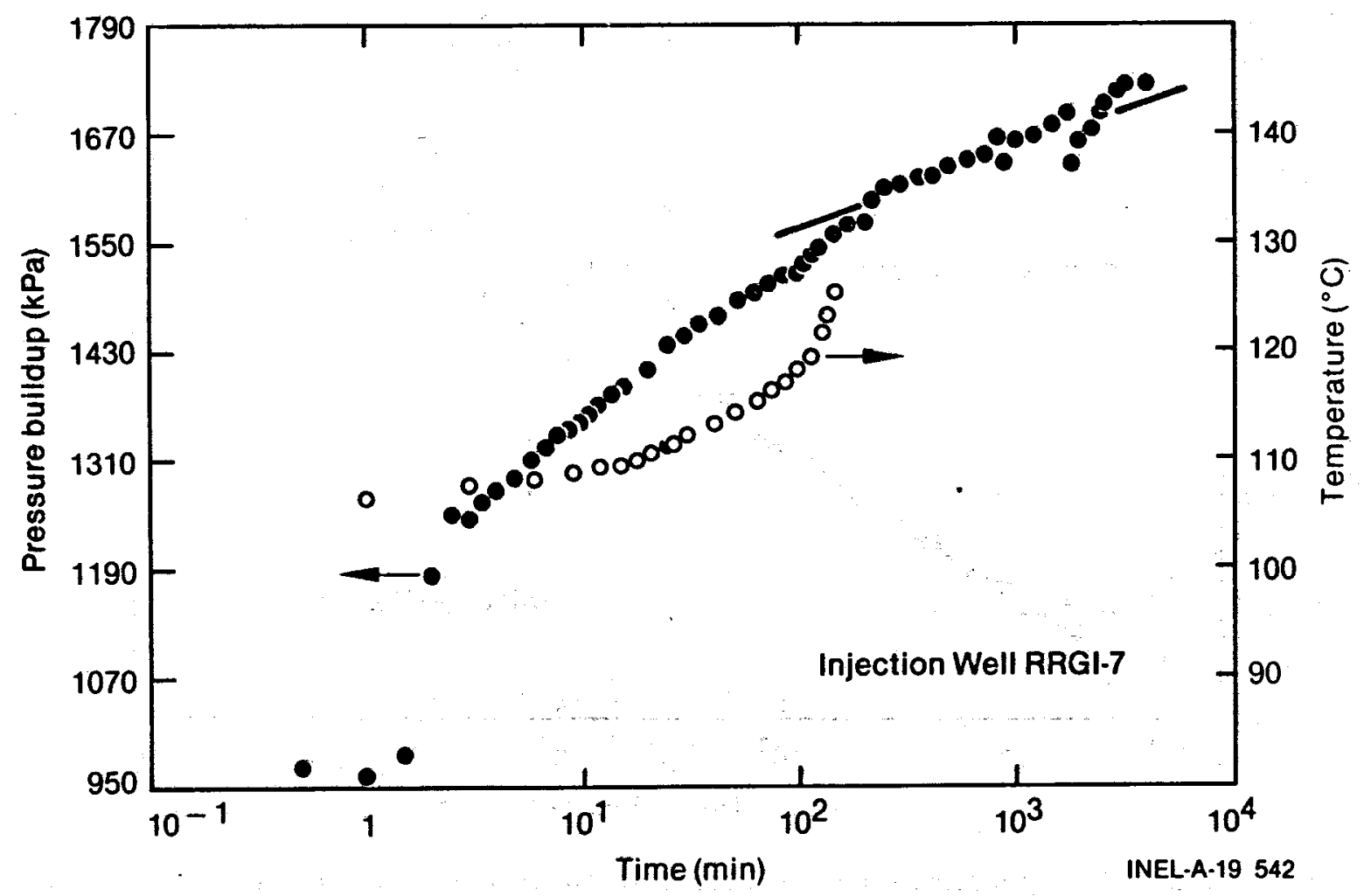

Figure 80. Pressure buildup and temperature during injection test of well RRGI-7, September 15, 1979. Test duration was 80 hours at an injection rate of $63 \mathrm{~L} / \mathrm{s}$. 
The injection part of the test may be analyzed for only the first $60 \mathrm{~min}$ of injection (Figure 81). After that, data are strongly influenced by changes in flow rate and interruptions in injection. Well parameters estimated from the injection test are: $\mathrm{Q} / \mathrm{s}_{10}=0.25(\mathrm{~L} / \mathrm{s}) /(\mathrm{kPa}) / \mathrm{log}$ cycle, $\mathrm{kH}_{\mathrm{a}}=1.0 \times 10^{-4} \mathrm{mD}$. $\mathrm{m}$, and $\mathrm{T}_{\mathrm{a}}=1.2 \times 10^{-4} \mathrm{~m}^{2} / \mathrm{s}$. The plot for recovery on August 20 (Figure 82) shows a change in slope after a $\mathrm{t} / \mathrm{t}$ of about 10. This change in slope is probably due to cooling of water in the wellbore. Analysis of reservoir parameters for early time shut-in $\left(\mathrm{t} / \mathrm{t}^{\prime}>0\right)$ gives: $\mathrm{Q} / \mathrm{s}_{10}=0.32(\mathrm{~L} / \mathrm{s}) /(\mathrm{kPa}) / \log$ cycle, $\mathrm{kH}_{\mathrm{a}}=1.2 \mathrm{x}$ $10^{4} \mathrm{mD} . \mathrm{m}$, and $T_{\mathrm{a}}=1.6 \times 10^{-4} \mathrm{~m}^{2} / \mathrm{s}$.

For the September 10 recovery (Figure 83), the continuous change in slope from thermal effects is again apparent. The well parameters estimated from the early shut-in data are: $\mathrm{Q} / \mathrm{s}_{10}=0.3(\mathrm{~L} / \mathrm{s}) /(\mathrm{kPa}) / \mathrm{log}$ cycle, $\mathrm{kH}_{\mathrm{a}}=0.2 \times 10^{4} \mathrm{mD} . \mathrm{m}$, and $\mathrm{T}_{\mathrm{a}}=1.5 \times 10^{-4} \mathrm{~m}^{2} / \mathrm{s}$. All the well parameter estimates are summarized in Table 28.

The 24-hour specific injectivity ranged from an anomalously low value of $0.08(\mathrm{~L} / \mathrm{s}) /(\mathrm{kPa})$ to a high value of $0.24(\mathrm{~L} / \mathrm{s}) / \mathrm{kPa}$. The three central values averaged $0.167(\mathrm{~L} / \mathrm{s}) / \mathrm{kPa}$. The productivity plot is shown in Figure 84. A linear least squares fit of the data yields the relation: $y=92.11+3.06 x$.

The interval of 623 to $1185 \mathrm{~m}$ is open to injection in RRGI-7 (Appendix B, Figure B-20). No loss of drilling fluid was noted during drilling of this interval. Available temperature logs indicate gradient changes in the intervals 940 to $980 \mathrm{~m}$ and 1100 to $1180 \mathrm{~m}$. Caliper logs show three zones of hole enlargement. Flow meter logs identify possible receiving zones at 730 to $790 \mathrm{~m}, 805$ to $830 \mathrm{~m}, 844$ to $905 \mathrm{~m}$, and 960 to $1000 \mathrm{~m}$.

Televiewer logs indicate possible significant openings at 637,672 , and $766 \mathrm{~m}$. Intergranular porosity and permeability exist in addition to some fracturing in the Tertiary sediments penetrated by RRGI-7. The major receiving zones probably occur in the interval 800 to $1000 \mathrm{~m}$. The projected pressure buildup as a function of injection rate is shown in Figure 85. These projections are based on an injection temperature of $150^{\circ} \mathrm{C}$.

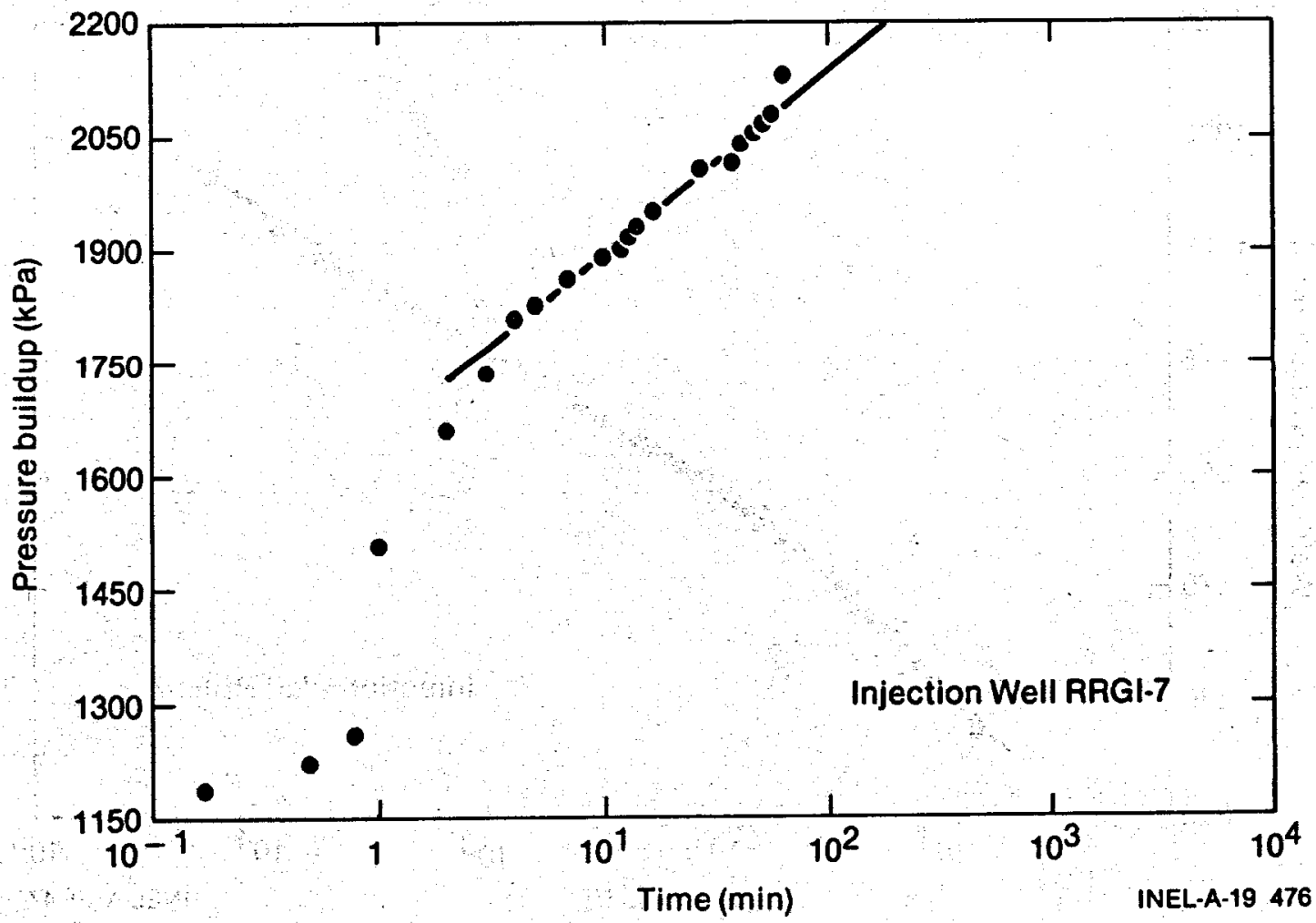

Figure 81. Pressure buildup during injection test of well RRGI-7, August 19-20, 1980. Test duration was 35 hours at an injection rate of $60 \mathrm{~L} / \mathrm{s}$. 


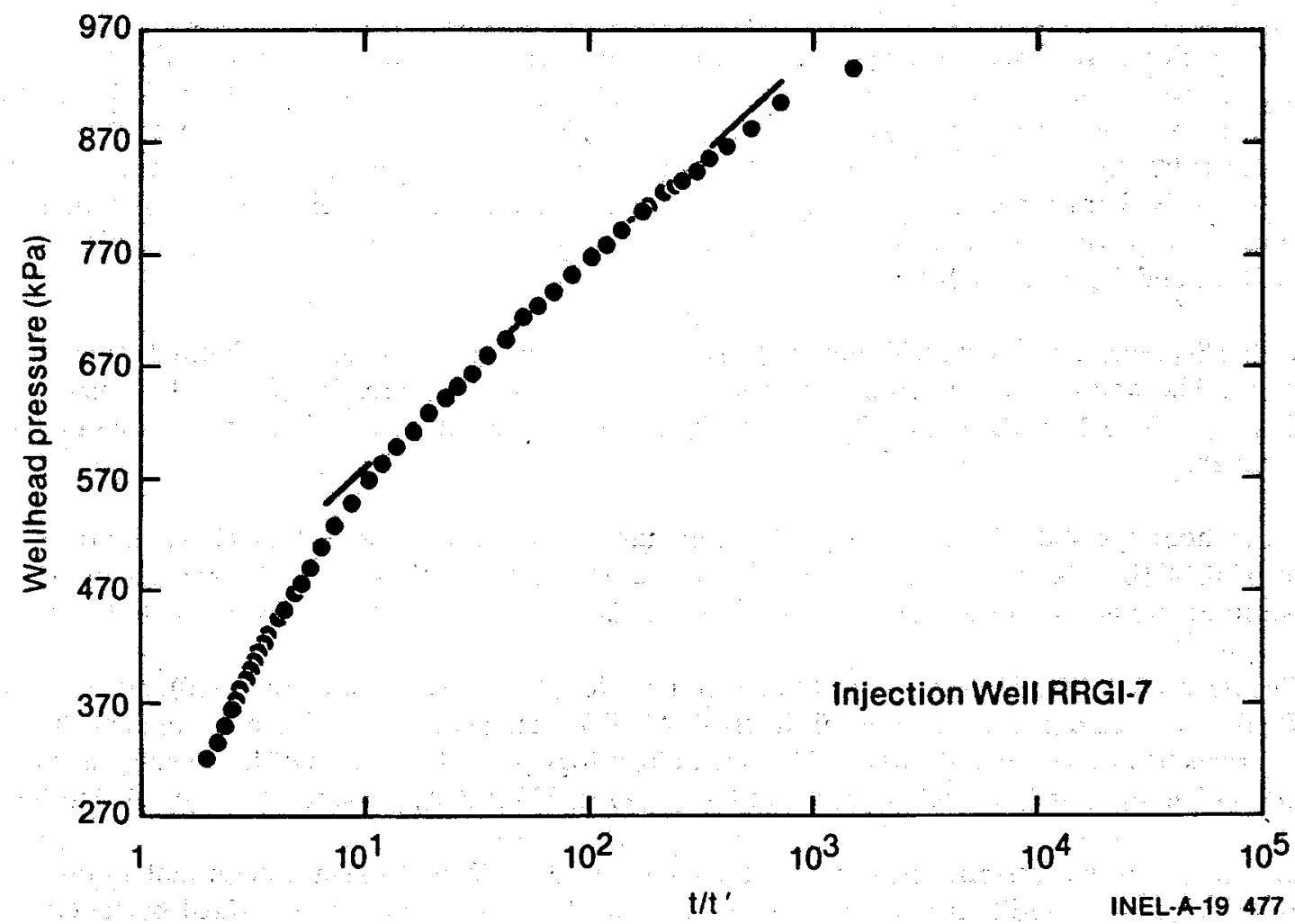

Figure 82. Pressure decline during recovery after injection test of well RRG1-7, August 19-20, 1980. Test duration was 30 hours at an injection rate of $60 \mathrm{~L} / \mathrm{s}$.

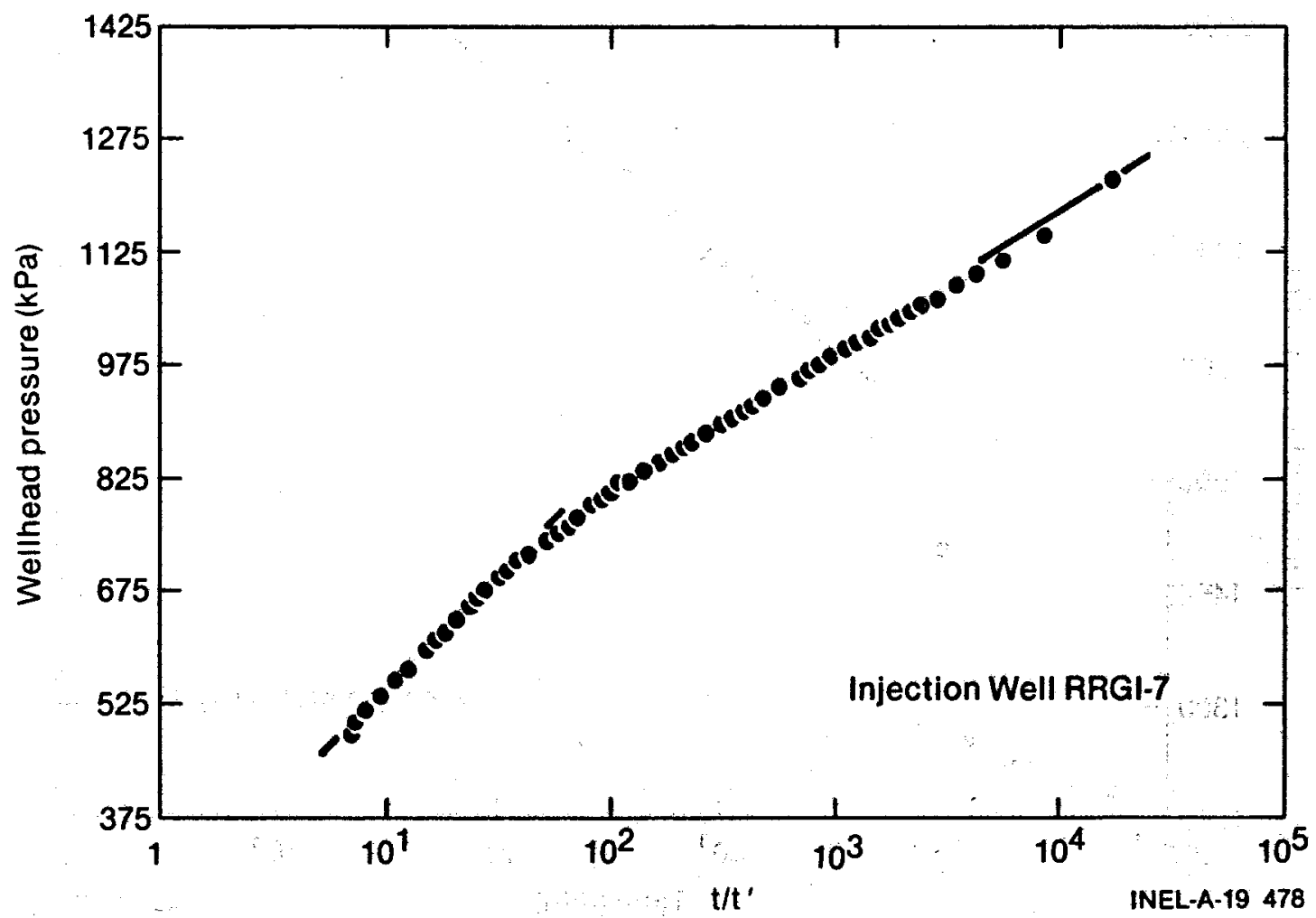

Figure 83. - Pressure decline recovery after injection test of well RRGI-7, August 28-September 10, 1980. Test duration was 285 hours at an injection rate of $60 \mathrm{~L} / \mathrm{s}$. 


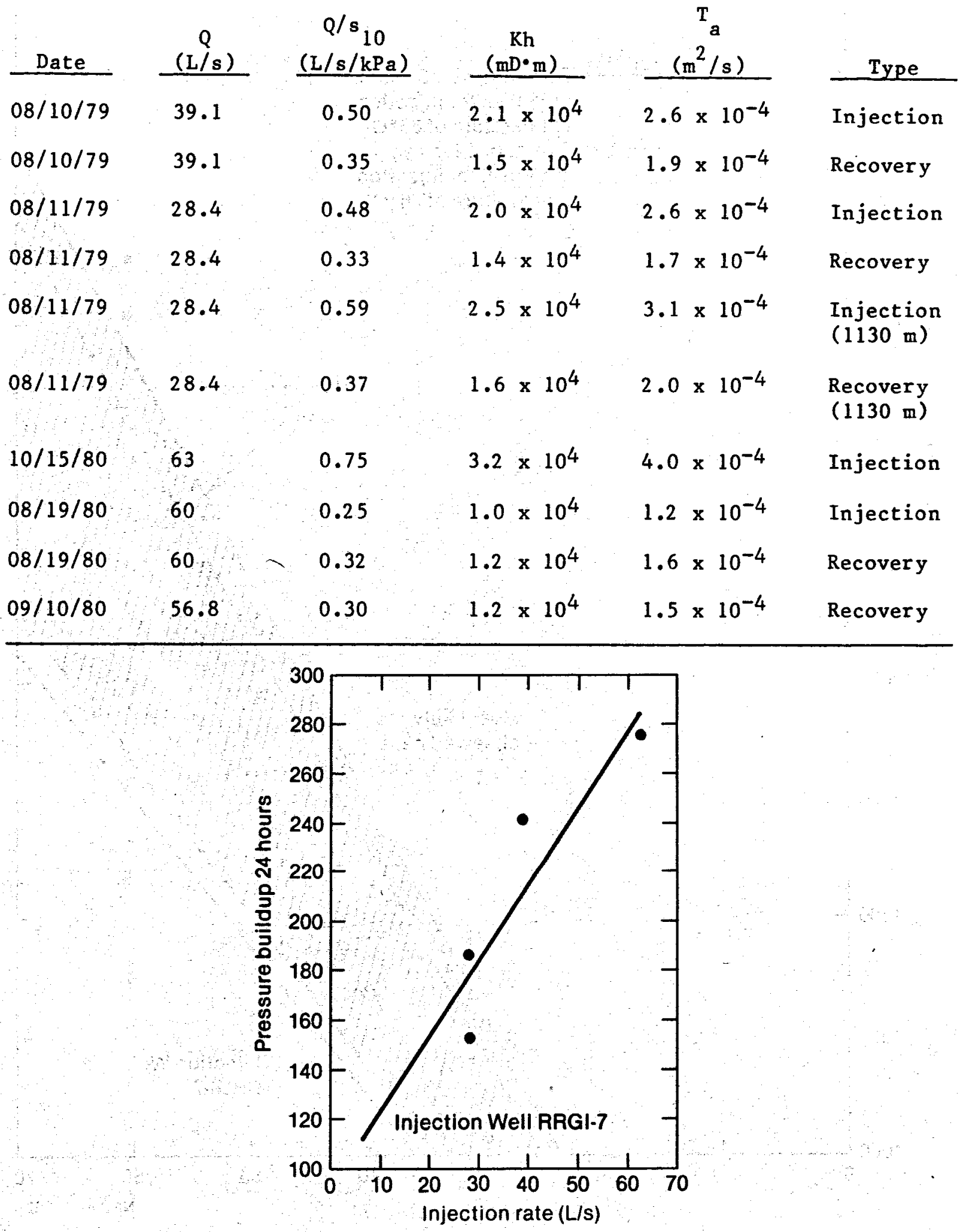

INEL-A-19 543

Figure 84. Injectivity curve of 24-hour data from injection well RRGI-7. 


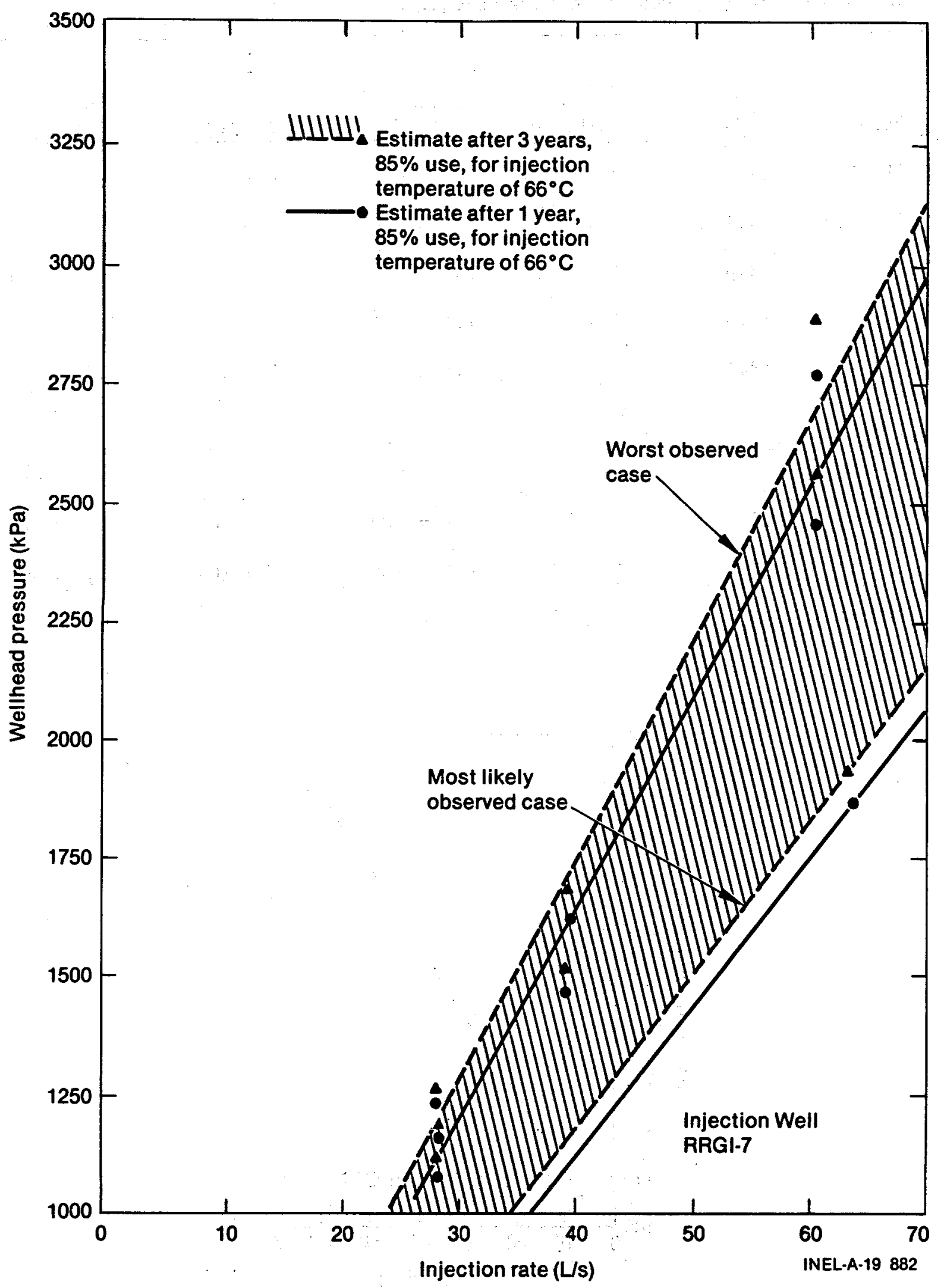

Figure 85. Predicted pressure buildup versus injection rate for injection well RRGI-7. 
4.5.8 Interference Testing. Interference tests conducted at Raft River are listed in Table 29. Testing has been attempted between all pairs of wells within the separate production and injection zones with two exceptions: the interference connections between wells RRGE-3 and RRGP-4, and between RRGE-3 and RRGP-5 have not been tested. Of the tests in which interference data were collected, five have been selected for analysis of reservoir properties.

The tests selected for analysis are: August 18, 1980-RRGE-1 and RRGP-4; May 16, 1979-RRGP-5 and RRGE-1, RRGP-5 and RRGP-4, RRGI-6 and RRGI-7; and August 11, 1979-RRGI-7 and RRGI-6. Three criteria were used to select these tests for analysis: (a) quality of data as characterized by the distinctness of a straight-line segment in a semi-logarithmic plot and the control maintained at the flowing well; (b) magnitude of pressure change in the observation well, a pressure change in excess of $3.5 \mathrm{kPa}$ was deemed necessary because the gravitational effects that cause earth tides also produce a cyclic pressure fluctuation with an amplitude of about $3.5 \mathrm{kPa}$; (c) duration of observation well data was compared to the amount of time required to satisfy the $\mathrm{u}=\mathbf{0 . 0 1}$ assumption that allows use of the Jacob straight-line technique to estimate reservoir properties. The time required to satisfy this assumption was calculated on assumed values of transmissivity $\left(T=1.5 \times 10^{-3} \mathrm{~m}^{2} / \mathrm{s}\right)$ and storativity $\left(S=1 \times 10^{-4}\right)$. The assumed value of $T$ was based on reservoir properties estimated from tests that satisfied the first two criteria.

The August 18, 1980 test, which involved production at RRGE-1 and observation at RRGP-4, satisfied the u condition at 6,400 min. Although data for this test are missing between 4,200 and 26,000 min (Figure 86), the last 7,000 min of data form a distinct straight-line that falls on data points obtained immediately prior to $4,200 \mathrm{~min}$. Reservoir properties estimated from this interference test are: $\mathbf{k H}_{\mathbf{a}}=$ $37000 \mathrm{mD} . \mathrm{m}$ and $\mathrm{T}_{\mathrm{a}}=1.6 \times 10^{-3} \mathrm{~m}^{2} / \mathrm{s}$. These values were calculated based on an assumed reservoir temperature of $138^{\circ} \mathrm{C}$.

A straight line fits easily after $5,000 \mathrm{~min}$, to the semi-logarithmic plot of data from the May 16, 1979 test (Figure 87), during which observations were made at RRGE-1 while RRGP-5 was pumping. This test would satisfy the u condition at $16,044 \mathrm{~min}$. Beyond that time, however, only three data points exist. Since these points do not form a perfect line, several earlier points were also used to formulate the straight-line from which reservoir properties were estimated. The reservoir properties were determined to be $\mathbf{k H}_{\mathrm{a}}=$ $19400 \mathrm{mD} . \mathrm{m}$ and $\mathrm{T}_{\mathrm{a}}=8: 3 \times 10^{-4} \mathrm{~m}^{2} / \mathrm{s}$.

Pressure response observations were also collected at RRGP-4 during the May 16, 1979 production at RRGP-5; these are shown in Figure 88. Observations at this well satisfy the $u$ assumption after 13,225 min, leaving six data points to which a straight line must be fitted for a Jacob analysis. The reservoir properties estimated from this test are: $\mathrm{kH}_{\mathrm{a}}=37000 \mathrm{mD} \cdot \mathrm{m}$ and $\mathrm{T}_{\mathrm{a}}=1.6 \times 10^{-3} \mathrm{~m}^{2} / \mathrm{s}$.

The geothermal fluids produced from RRGP-5 during the May 16, 1979 test were injected at RRGI-6 for disposal and evaluation of the injection zone at Raft River. Interference effects of the injection test were monitored in RRGI-7. The pressure response as a function of time is shown in Figure 89. Under the assumed transmissivity and storage values, the u assumption at RRGI-7 was satisfied after 6,670 min. Data points following $6,670 \mathrm{~min}$ do not form a straight line until after $16,000 \mathrm{~min}$. The resulting straight line suggests $\mathrm{kH}_{\mathrm{a}}=45000 \mathrm{mD} \cdot \mathrm{m}$ and $\mathrm{T}_{\mathrm{a}}=1.9 \times 10^{-3} \mathrm{~m}^{2} / \mathrm{s}$.

Another interference test within the injection zone is depicted in Figure 90. The August 11, 1979 test involved injection at RRGI-7 and observation at RRGI-6. Several things caused this test to be of marginal value: the duration of observation exceeds the time required to satisfy the $u$ assumption by only $331 \mathrm{~min}$; observed pressures during the last $300 \mathrm{~min}$ of observations are erratic; and the total pressure change was only $3.5 \mathrm{kPa}$. Since the small pressure change occurred over a period of $5,000 \mathrm{~min}$, much longer than the gravitational effects would be influential, and because this test provides only the second reasonably acceptable interference test in the injection zone, it was decided to estimate reservoir properties and to use the resulting values with an appropriate degree of caution when interpreting implications for the conceptual reservoir model. Based on this test, $\mathrm{kH}_{\mathrm{a}}=3000 \mathrm{mD} . \mathrm{m}$ and $\mathrm{T}_{\mathrm{a}}=3.6 \times 10^{-3} \mathrm{~m}^{2} / \mathrm{s}$.

Table 30 summarizes results obtained from interpreting interference test data. 
Table 29. Summary of interference testing

\begin{tabular}{|c|c|c|c|c|c|c|}
\hline Date & $\begin{array}{l}\text { Active } \\
\text { We } 11 \\
\end{array}$ & $\begin{array}{l}\text { Observation } \\
\text { We11 } \\
\end{array}$ & $\begin{array}{c}\text { Radius } \\
(\mathrm{km}) \\
\end{array}$ & $\begin{array}{l}\text { Duration of } \\
\text { Observation } \\
\text { (min) } \\
\end{array}$ & $\begin{array}{c}Q \\
(L / s)\end{array}$ & Comments \\
\hline $08 / 18 / 80$ & RRGE-1 & RRGI-4 & 0.48 & 32,000 & 56.8 & $\begin{array}{l}\text { Data between } 4,200 \text { and } 25,000 \mathrm{~min} \text { not } \\
\text { collected, maximum drawdown } 87 \mathrm{kPa} \text {. }\end{array}$ \\
\hline $\begin{array}{l}05 / 09 / 78 \\
05 / 10 / 78\end{array}$ & RRGE-2 & $\begin{array}{l}\text { RRGE-1 } \\
\text { RRGE-1 }\end{array}$ & $\begin{array}{l}1.21 \\
1.21\end{array}$ & $\begin{array}{l}300 \\
900\end{array}$ & $\begin{array}{l}50.5 \\
37.8\end{array}$ & $\begin{array}{l}\text { Maximum drawdown } 5.5 \mathrm{kPa} \\
\text { Maximum drawdown } 6.2 \mathrm{kPa}\end{array}$ \\
\hline $\begin{array}{l}09 / 20 / 75 \\
03 / 20 / 79 \\
03 / 20 / 79 \\
05 / 30 / 79 \\
08 / 11 / 79\end{array}$ & $\therefore \quad \therefore$ & $\begin{array}{l}\text { RRGE-1 } \\
\text { RRGE-3 } \\
\text { RRGI-4 } \\
\text { RRGE-1 } \\
\text { RRGE-3 }\end{array}$ & $\begin{array}{l}1.21 \\
2.22 \\
1.66 \\
1.21 \\
2.22\end{array}$ & $\begin{array}{r}30,000 \\
45,000 \\
30,000 \\
3,500 \\
10,000\end{array}$ & $\begin{array}{l}25.2 \\
37.8 \\
37.8 \\
46.7 \\
28.4\end{array}$ & $\begin{array}{l}\text { Maximum drawdown } 27.6 \mathrm{kPa} \\
\text { Maximum drawdown } 68.6 \mathrm{kPa} \\
\text { Maximum drawdown } 68.6 \mathrm{kPa} \\
\text { Erratic data, maximum drawdown } 82.7 \mathrm{kPa} \\
\text { Erratic data, maximum drawdown } 3.4 \mathrm{kPa}\end{array}$ \\
\hline $\begin{array}{l}06 / 08 / 76 \\
07 / 06 / 77\end{array}$ & RRGE-3 & $\begin{array}{l}\text { RRGE }-1 \\
\text { RRGE-2 }\end{array}$ & $\begin{array}{l}1.86 \\
2.22\end{array}$ & $\begin{array}{r}12,000 \\
300\end{array}$ & $\begin{array}{l}\text { Variable } \\
37.8\end{array}$ & Maximum drawdown $\mathrm{l} \mathrm{kPa}$ \\
\hline $05 / 17 / 78$ & RRGI-4 & RRGE-1 & 0.48 & 2,500 & 37.8 & $\begin{array}{l}\text { Injection configuration, erratic data, } \\
\text { maximum drawdown } 17.2 \mathrm{kPa}\end{array}$ \\
\hline $11 / 02 / 78$ & & RRGE-2 & 1.66 & 11,000 & 6.3 & $\begin{array}{l}\text { Injection configuration, maximum draw- } \\
\text { down } 3.4 \mathrm{kPa}\end{array}$ \\
\hline $11 / 29 / 78$ & & RRGE-1 & 0.48 & 1,100 & 1.6 & $\begin{array}{l}\text { Production configuration, very erratic } \\
\text { data, maximum drawdown } 20.7 \mathrm{kPa}\end{array}$ \\
\hline $\begin{array}{l}11 / 01 / 78 \\
11 / 01 / 78\end{array}$ & RRGP-5 & $\begin{array}{l}\text { RRGE - } 1 \\
\text { RRGE }-2\end{array}$ & $\begin{array}{l}0.76 \\
1.89\end{array}$ & $\begin{array}{l}4,500 \\
4,500\end{array}$ & $\begin{array}{l}8.8 \\
8.8\end{array}$ & $\begin{array}{l}\text { Maximum drawdown } 8.3 \mathrm{kPa} \\
\text { Maximum drawdown } 6.2 \mathrm{kPa}\end{array}$ \\
\hline $\begin{array}{l}05 / 16 / 79 \\
05 / 16 / 79\end{array}$ & & $\begin{array}{l}\text { RRGE-1 } \\
\text { RRGI-4 }\end{array}$ & $\begin{array}{l}0.76 \\
0.69\end{array}$ & $\begin{array}{l}25,000 \\
30,000\end{array}$ & $\begin{array}{l}40.4 \\
40.4\end{array}$ & $\begin{array}{l}\text { Maximum drawdown } 68.6 \mathrm{kPa} \\
\text { Maximum drawdown } 34.5 \mathrm{kPa}\end{array}$ \\
\hline $01 / 09 / 79$ & RRGI-6 & RRGI-7 & 0.49 & 9,600 & Variable & $\begin{array}{l}\text { Injection at RRGI- } 6 \text { was pulse-type, max- } \\
\text { imum buildup } 12.4 \mathrm{kPa}\end{array}$ \\
\hline $\begin{array}{l}03 / 20 / 79 \\
05 / 16 / 79\end{array}$ & & $\begin{array}{l}\text { RRGI-7 } \\
\text { RRGI-7 }\end{array}$ & $\begin{array}{l}0.49 \\
0.49\end{array}$ & $\begin{array}{l}30,000 \\
30,000\end{array}$ & $\begin{array}{l}37.8 \\
40.4\end{array}$ & $\begin{array}{l}\text { Maximum buildup } 10.3 \mathrm{kPa} \\
\text { Maximum buildup } 18.6 \mathrm{kPa}\end{array}$ \\
\hline $\begin{array}{l}08 / 11 / 79 \\
08 / 11 / 79\end{array}$ & RRGI-7 & $\begin{array}{l}\text { RRGE-3 } \\
\text { RRGI-6 }\end{array}$ & $\begin{array}{l}0.94 \\
0.49\end{array}$ & $\begin{array}{l}3,000 \\
7,000\end{array}$ & $\begin{array}{l}28.4 \\
28.4\end{array}$ & $\begin{array}{l}\text { Maximum buildup } 3.4 \mathrm{kPa} \\
\text { Maximum buildup } 3.4 \mathrm{kPa}\end{array}$ \\
\hline
\end{tabular}




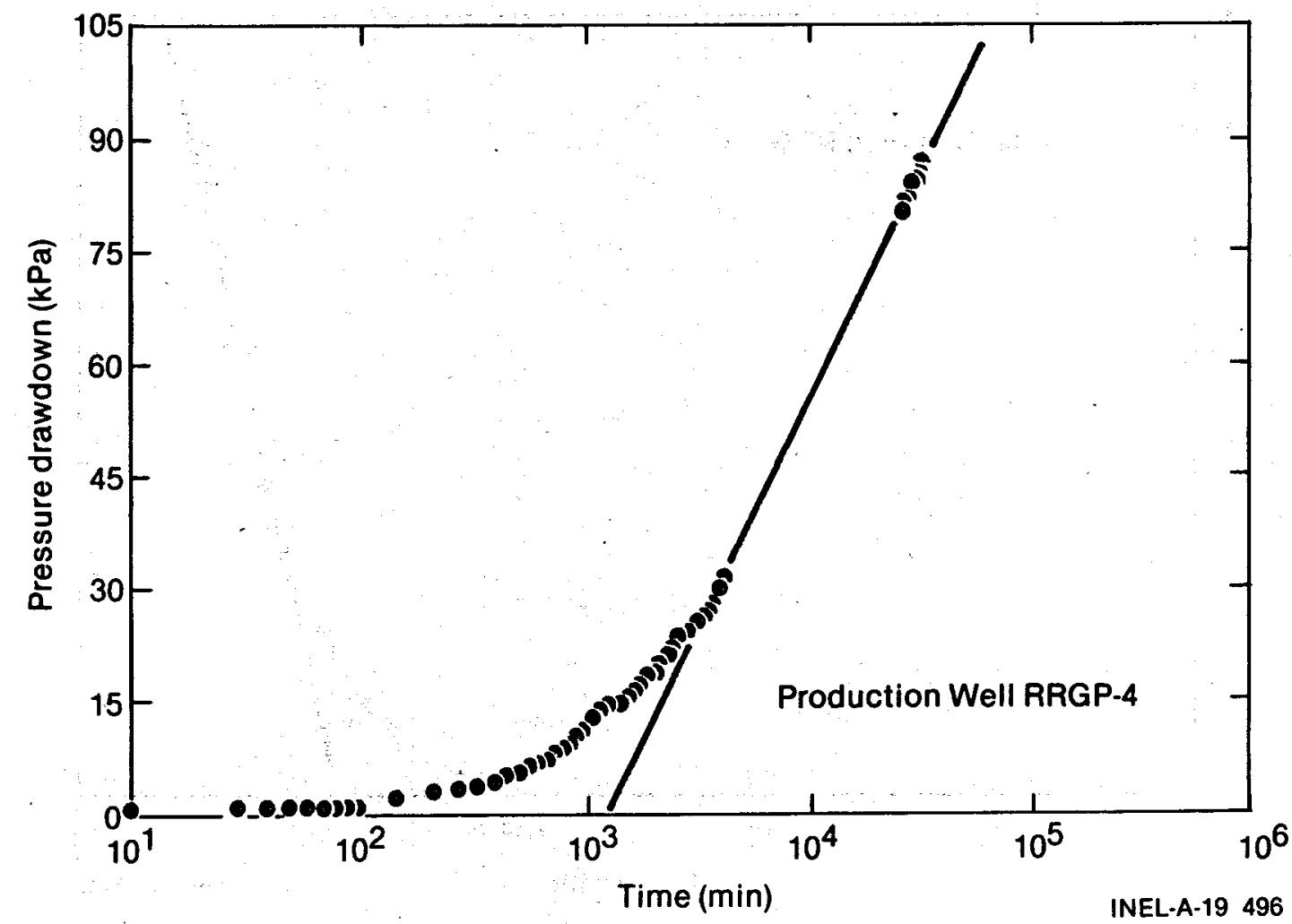

Figure 86. Pressure drawdown observed at well RRGP-4 during production at well RRGE-1 on August 18, 1980. The production rate in RRGE-1 was $56.8 \mathrm{~L} / \mathrm{s}$; observation of well RRGP-4 continued for 533 hours.

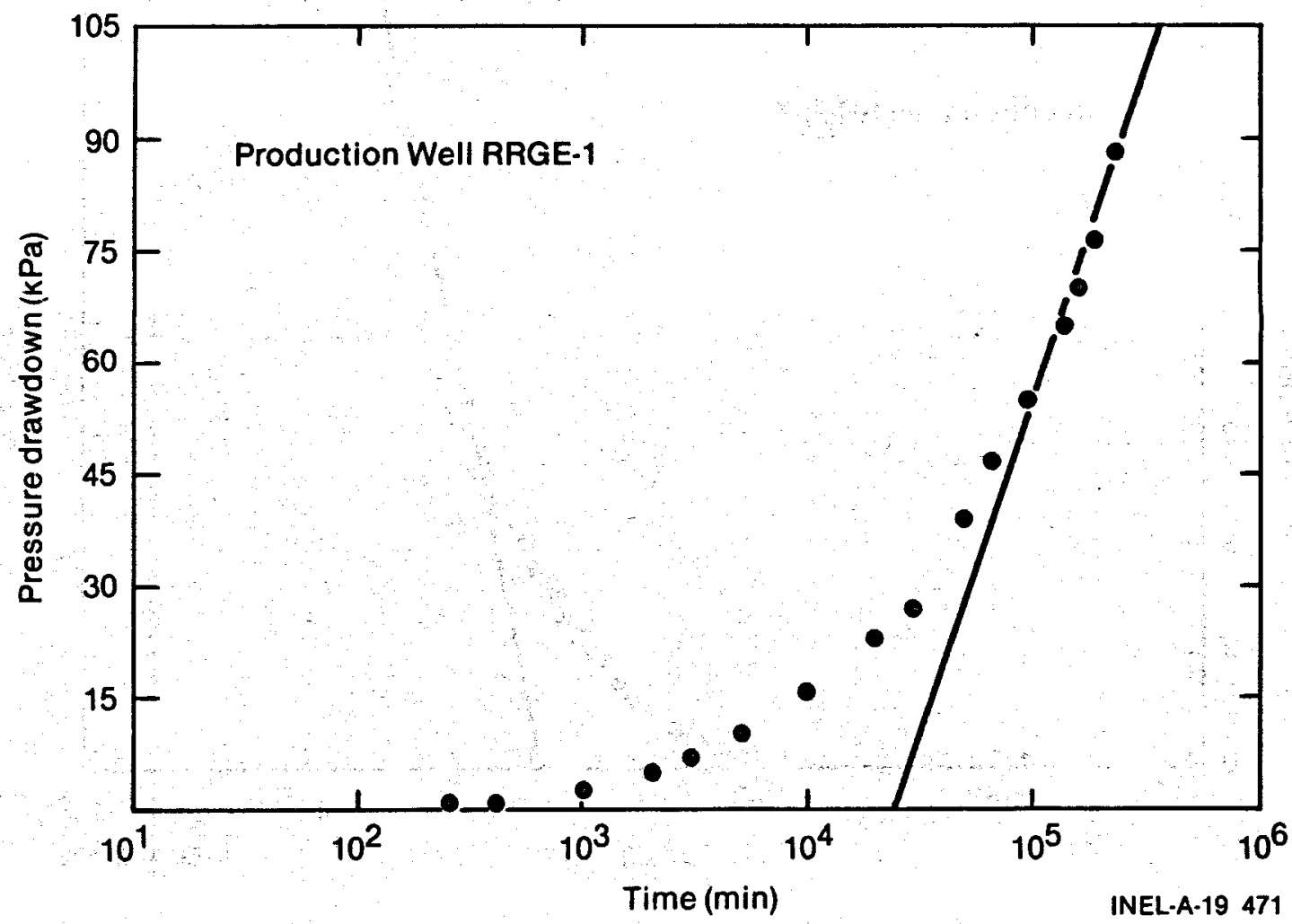

Figure 87. Pressure drawdown observed at well RRGE-1 during production at RRGP-5 on May 16, 1979. The production rate was $40.4 \mathrm{~L} / \mathrm{s}$; observation of well RRGE-1 continued for 417 hours. 


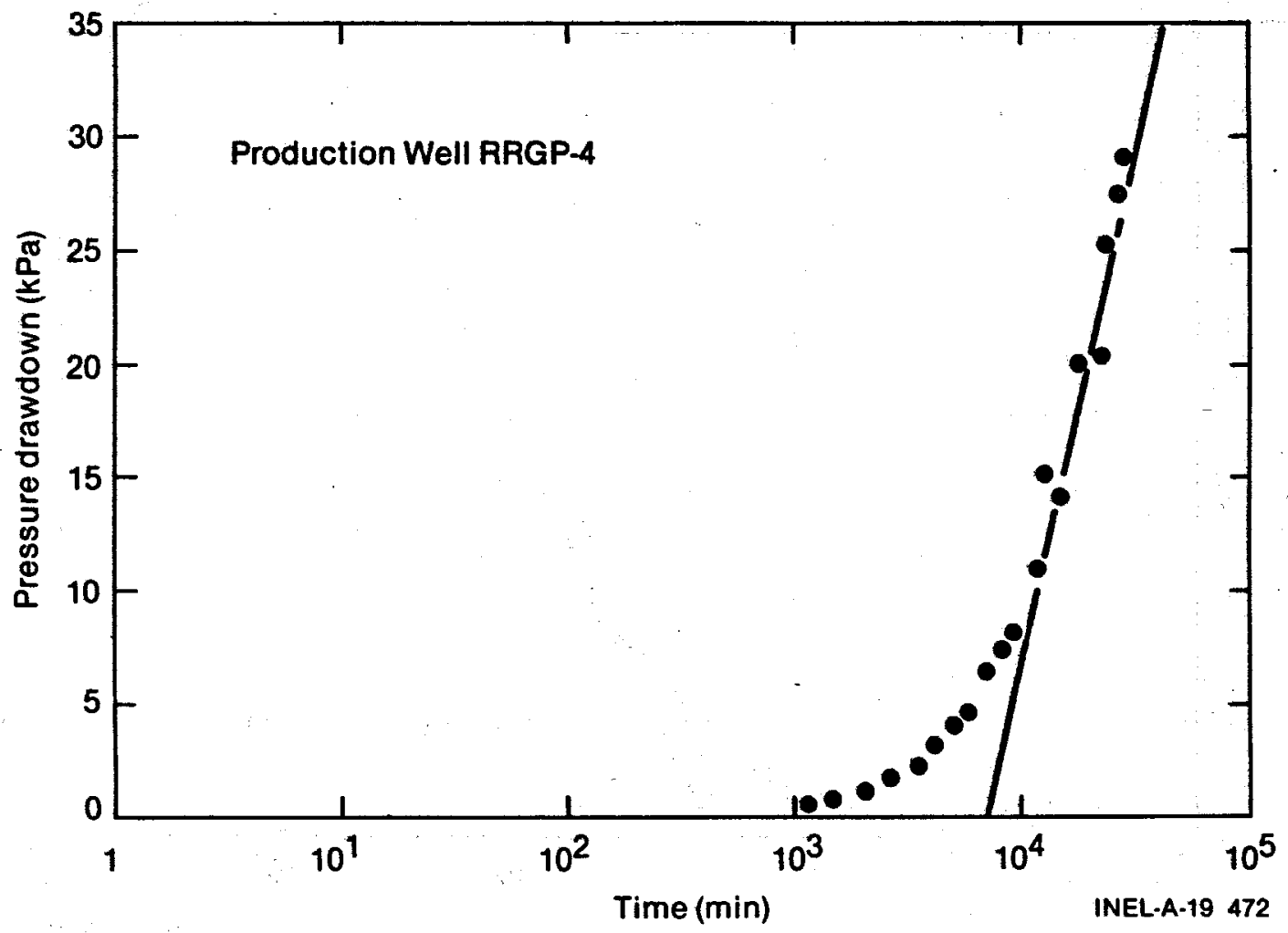

Figure 88. Pressure drawdown observed at well RRGP-4 during production at RRGP-5 on May 16, 1979. The production rate was $40.4 \mathrm{~L} / \mathrm{s}$; observation of well RRGP-4 continued for 500 hours.

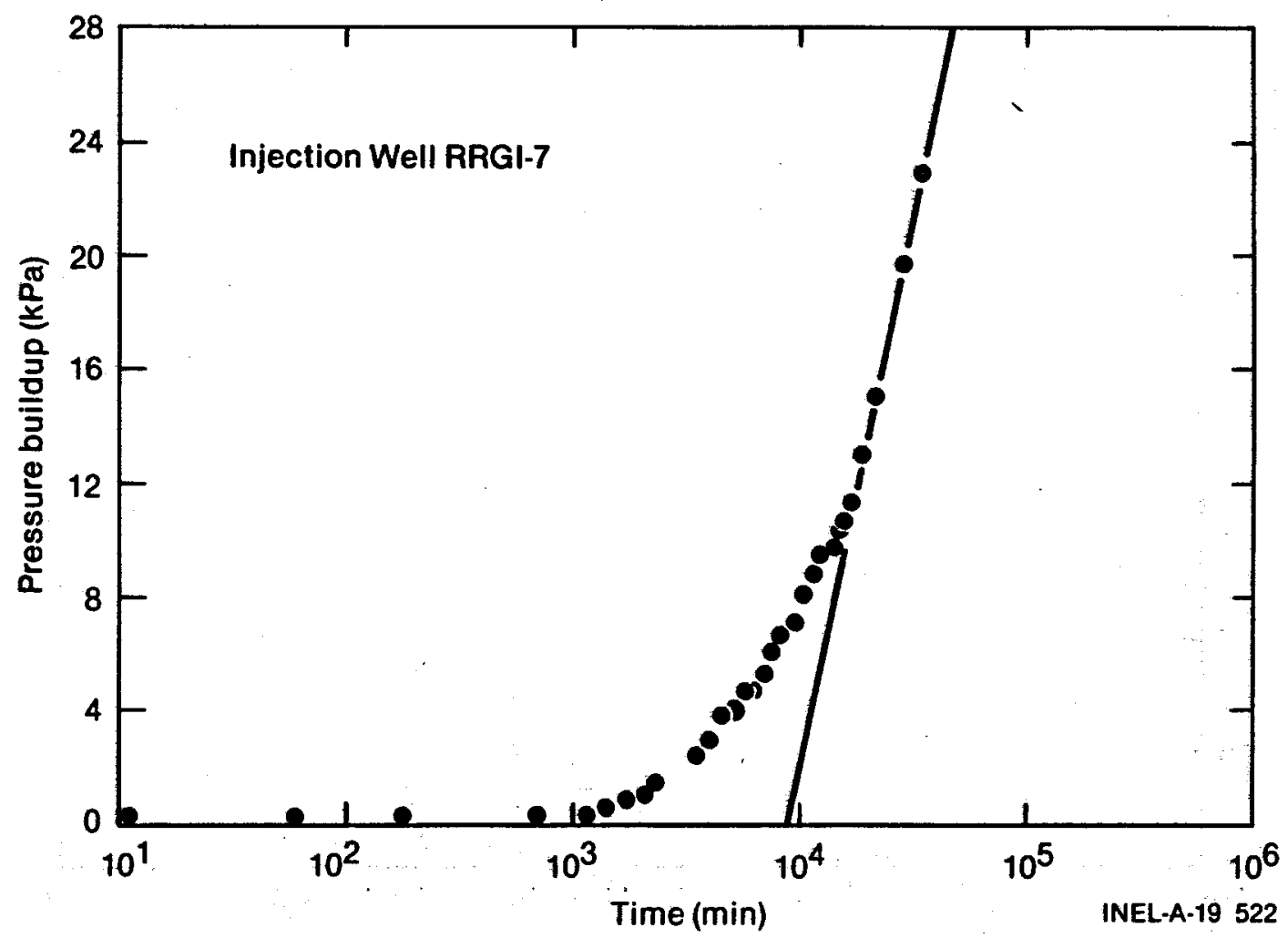

Figure 89. Wellhead pressure buildup at well RRGI-7 during injection at RRGI-6 on May 16, 1979. The injection rate was $40.4 \mathrm{~L} / \mathrm{s}$; observation of well RRGI-7 continued for 500 hours. 


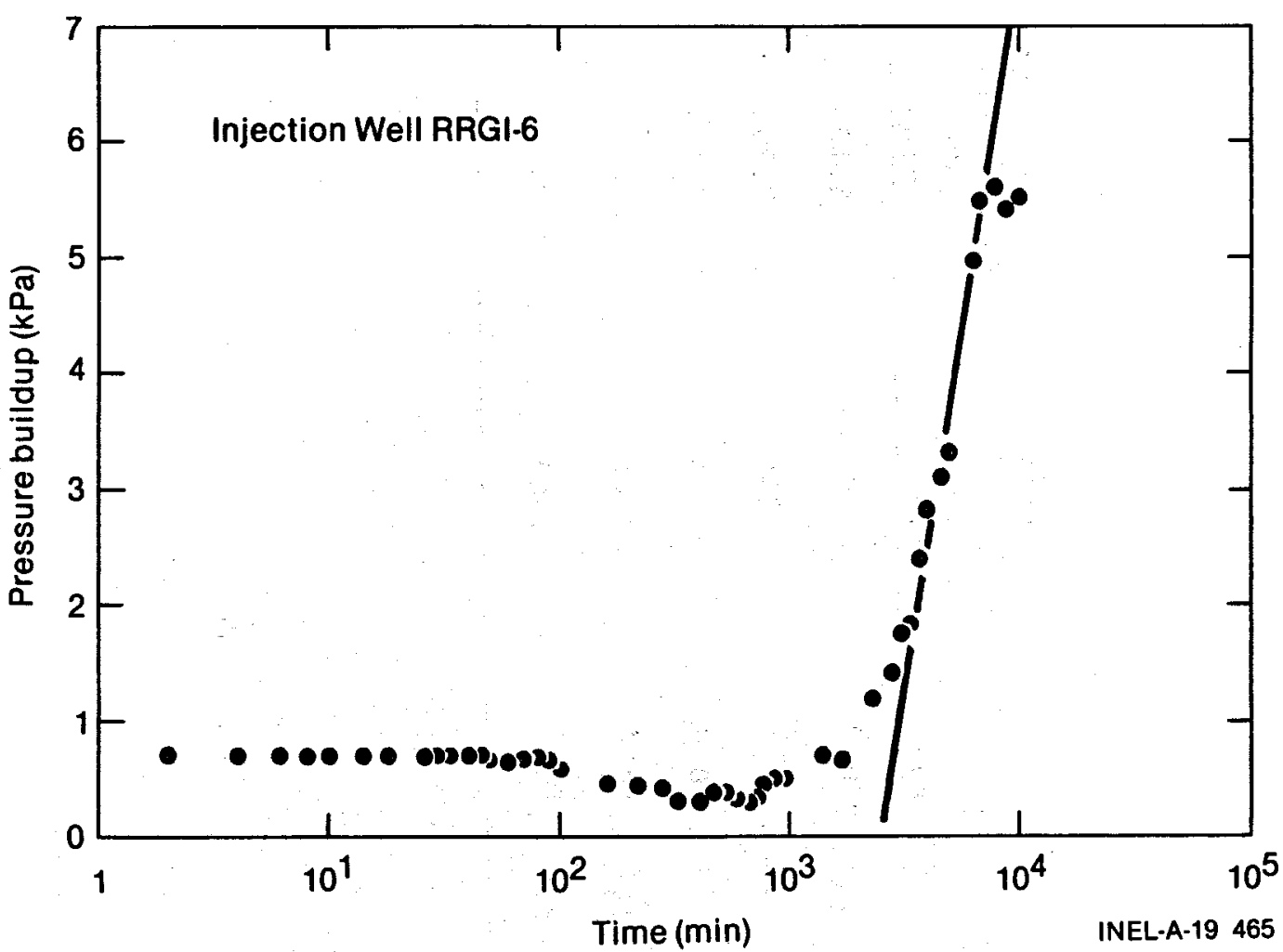

Figure 90. Wellhead pressure buildup at well RRGI-6 during injection at well RRGI-7 on August 11, 1979. The injection rate was $28.4 \mathrm{~L} / \mathrm{s}$; observation of well RRGI- 6 continued for 117 hours.

The May 16, 1979 interference test is the only one for which data were collected at two observation points. Pressure response at both RRGE-1 and RRGI-4 was recorded during production at RRGP-5. The two sets of data may allow at least a qualitative interpretation of reservoir anisotropy. Quantitative determination of anisotropy is not possible because the principal direction of flow is not fully characterized. Reservoir properties estimated from data obtained at RRGE-1 and RRGP-5 (Table 30) are different by a factor of about 2 . These wells are separated by a 38-degree angle. The larger reservoir properties estimated from this test occur for data collected at RRGP-4, which form a line that is almost perpendicular to the long axis of the Narrows Structure. Thus, the anisotropy identified from this test may be a local condition and not representative of the entire reservoir.

Table 31 lists the pressure response of each well to production, or injection, in that well and each of the other wells that penetrate the same zone of the reservoir. Pressure response at the end of one year and three years of $85 \%$ usage is predicted for the assumed flow rates indicated in Table 31 .

Pressure response in each well, due solely to that well's use in production or injection of geothermal fluids, was obtained from information presented in the well-by-well review of reservoir testing. The listed values represent the worst case response prediction made for each well for the specific time period and pumping rate.

The pressure responses in Table 31 that reflect interference between wells were calculated from:

$s=\frac{Q}{4 \pi T} \ln \left(\frac{4 T s}{r^{2} s}\right)$

This is the nonequilibrium or Theis equation of pressure response at any point as a function of reservoir properties and flow rate. ${ }^{69}$ In this equation: $Q$ is flow rate $L^{3} / T ; T$ is reservoir transmissivity $L 2 / T ; S$ is 
Table 30. Summary of reservoir properties from interference data

\begin{tabular}{|c|c|c|c|c|c|c|c|}
\hline Date & $\begin{array}{c}\text { Active } \\
\text { Well }\end{array}$ & $\begin{array}{c}\text { Observation } \\
\text { Well } \\
\end{array}$ & $\begin{array}{c}\mathrm{S}_{10} \\
(\mathrm{kPa} / \log \text { cycle }) \\
\end{array}$ & $\begin{array}{c}\mathrm{kH} \\
\mathrm{a} \\
(\mathrm{mD} \cdot \mathrm{m}) \\
\end{array}$ & $\begin{array}{c}\mathrm{T} \\
\mathrm{a} \\
\left(\mathrm{m}^{2} / \mathrm{s}\right) \\
\end{array}$ & $\begin{array}{c}\text { Time Required to } \\
\text { Satisfy "u" } \\
\text { Assumption } \\
\text { (min) } \\
\end{array}$ & $\begin{array}{c}\text { Duration Beyond } \\
\text { Satisfaction } \\
\text { of "u" } \\
\text { (min) }\end{array}$ \\
\hline $08 / 18 / 80$ & RRGE-1 & RRGP-4 & 62.7 & 37000 & $1.6 \times 10^{-3}$ & 6,400 & 25,100 \\
\hline $05 / 16 / 79$ & RRGP-5 & RRGE-1 & 68.2 & 19400 & $8.3 \times 10^{-4}$ & 16,044 & 8,956 \\
\hline $05 / 16 / 79$ & RRGP-5 & RRGP-4 & 44.0 & 37000 & $1.6 \times 10^{-3}$ & 13,225 & 16,775 \\
\hline $05 / 16 / 79$ & RRGI-6 & RRGI-7 & 36.0 & 45000 & $1.9 \times 10^{-3}$ & 6,669 & 23,331 \\
\hline $08 / 11 / 79$ & RRGI-7 & RRGI-6 & 13.8 & 83000 & $3.6 \times 10^{-3}$ & 6,669 & 331 \\
\hline
\end{tabular}


Table 31. Predicted pressure response $(\mathrm{kPa})$ at this end of 1 year $\left(t_{1}\right)$ and 3 years $\left(t_{3}\right)$ of operation, at $85 \%$ usage, in each well

\begin{tabular}{|c|c|c|c|c|c|c|c|c|c|c|c|c|c|c|c|c|}
\hline \multirow[b]{2}{*}{ Well } & \multirow[b]{2}{*}{$\begin{array}{c}Q \\
(L / 8) \\
\end{array}$} & \multicolumn{3}{|c|}{ RRGE-1 } & \multicolumn{2}{|c|}{ RRGE-2 } & & \multicolumn{3}{|c|}{ RRGE-3 } & \multicolumn{3}{|c|}{ RRGP-4 } & \multicolumn{3}{|c|}{ RRGP-5 } \\
\hline & & $\begin{array}{c}\text { Radius } \\
(\mathrm{km}) \\
\end{array}$ & $t_{1}$ & $t_{3}$ & $\begin{array}{c}\text { Radius } \\
(\mathrm{km}) \\
\end{array}$ & $t_{1}$ & $t_{3}$ & $\begin{array}{l}\text { Radius } \\
(\mathrm{km})\end{array}$ & $t_{1}$ & $t_{3}$ & $\begin{array}{l}\text { Radius } \\
(\mathrm{km})\end{array}$ & $t_{1}$ & $t_{3}$ & $\begin{array}{c}\text { Radius } \\
(\mathrm{km})\end{array}$ & $t_{1}$ & $t_{3}$ \\
\hline RRGE-1 & 76 & 0 & $3222^{a}$ & $3379^{a}$ & 1.21 & 295 & 342 & 1.86 & 258 & 305 & 0.48 & 374 & $42 I$ & 0.76 & 335 & 382 \\
\hline RRGE-2 & 63 & 1.21 & 244 & 283 & 0 & $9800^{a}$ & $10100^{a}$ & 2.22 & 201 & 240 & 1.66 & 222 & 261 & 1.89 & 212 & 252 \\
\hline RRGE-3 & 44 & 1.86 & 149 & 177 & 2.22 & 140 & 168 & 0 & $5716^{a}$ & $6308^{a}$ & 1.31 & 167 & 194 & 2.35 & 138 & 165 \\
\hline RRGP-4 & - & 0.48 & - & - & 1.66 & -- & - & 1.31 & -- & - & 0 & $\therefore$ & - & 0.69 & - & -- \\
\hline RRGP-5 & 63 & 0.76 & 277 & 317 & 1.89 & 212 & 252 & 2.35 & 197 & 236 & 0.69 & 284 & 226 & 0 & $\underline{1690}^{a}$ & $1760^{a}$ \\
\hline Total & 246 & & 3892 & 4156 & & 10447 & 10862 & 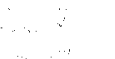 & 6372 & 7089 & & 1047 & 1102 & & 2375 & 2559 \\
\hline & & & RRGI-6 & $\therefore$ & & RRCI -7 & & & & & & & & & & \\
\hline Well & $\begin{array}{c}Q \\
(L / B) \\
\end{array}$ & $\begin{array}{l}\text { Radius } \\
(\mathrm{km})\end{array}$ & $t_{1}$ & $t_{3}$ & $\begin{array}{r}\text { Radius } \\
(\mathrm{km})\end{array}$ & $t_{1}$ & $t_{3}$ & & & & & & & & & \\
\hline RRGI-6 & 123 & 0 & $3883^{n}$ & $390^{\circ}$ & 0.49 & 339 & 378 & & & & & & & & & \\
\hline RRGI-7 & 123 & 0.49 & 339 & 378 & 0 & $3984^{a}$ & $4064^{\mathrm{a}}$ & & & & & & & & & \\
\hline Total & 246 & & 4222 & 4368 & & 4323. & 4442 & & & & & & & & & \\
\hline
\end{tabular}

a. Worst case observed. 
the storage coefficient of the reservoir and is dimensionless; $r$ is the distance from the flowing well to the point at which $s$ is to be found ( $L)$; $t$ is the time, measured from the start of pumping, when $s$ is desired (t). When these inputs to the equation for $s$ are in consistent units $s$, the pressure response $r$ distance away after $t$ time, will have length $(L)$ units; i.e., pressure response is given in length of a column of water. Pressure in height of water can easily be converted to true pressure units of weight per unit volume if the specific gravity, $\gamma$ of water at the temperature of interest is known.

Transmissivity values used for calculations of interference effects were obtained by taking a geometric mean of the transmissivity estimated from interference testing. As a result, $T=1.3 \times 10^{-3} \mathrm{~m}^{2} / \mathrm{s}$ in the production zone and $T=2.6 \times 10^{-3} \mathrm{~m}^{2} / \mathrm{s}$ in the injection zone. No information is available to estimate the storage coefficient, so $\mathrm{S}=1 \times 10^{-4}$ was assumed. The apparent temperature of the production zone, $132^{\circ} \mathrm{C}$, leads to $\gamma=58.81 \mathrm{lb} / \mathrm{ft}^{3}$. Injection fluids are antícipated to be $66^{\circ} \mathrm{C}$ and thus give $\gamma=$ $61.19 \mathrm{lb} / \mathrm{ft}^{3}$.

Within the production zone, the greatest amount of pressure drawdown will occur in RRGE-2 where, after three years of $85 \%$ usage, pressure will have decreased by $10862 \mathrm{kPa}$. The least amounts of pressure drawdown will occur in the vicinity of wells RRGE-1 and RRGP-5; pressure in RRGP-5 will decrease $2559 \mathrm{kPa}$ and pressure in RRGE-1 will decrease $4156 \mathrm{kPa}$. Note that the assumed production program does not include production at RRGP-4; this is because of low flow capabilities identified during testing. Thus, the 1102-kPa pressure decrease shown for RRGP-4 results exclusively from production at other wells.

Pressure buildup in the injection zone is fairly uniform because both injection wells are assumed to flow at the same rate. Since there are only two wells and they flow at the same rate, the interference effect of each well on the other is identical.

4.5.9 Monitor Well Effects. The Raft River Monitor Well Program was designed to evaluate and predict the impact of geothermal development on the intermediate ground water aquifers. Seven intermediate monitoring wells (MW-1 through MW-7), drilled in 1978, are located near the intermediate depth geothermal injection and withdrawals wells. The depth and location of each well was designed to detect any response to geothermal injection before a response is noticeable at irrigation or domestic wells. Each monitor well is equipped with either a Stevens water level recorder or a digiquartz pressure transducer to provide continuous records of the potentiometric water level. Water samples for chemical analysis are taken each quarter to detect changes in water chemistry caused by geothermal development.

The aquifers penetrated by the monitor wells are sensitive to external influences such as barometric pressure changes, earth tides, irrigation pumping, and geothermal injection. There is no noticeable response to geothermal fluid withdrawal. 70

The monitor well hydrographs for the period from 1979 to the present show ground water level changes related to long-term trends and to annual seasonal fluctuations. Local shallow aquifers within the Raft River basin have had a declining long-term trend due to extensive irrigation pumping. ${ }^{71}$ A discussion of the annual seasonal fluctuations and the response to external influences for each well follows.

Monitor Well-1 (MW-1) was located to monitor the effects of injection into RRGI-4. MW-1 is a flowing well, drilled to $399 \mathrm{~m}$. Water level data in 1979 were collected sporadically and are not recorded on the long-term hydrograph (Figure 91). Injection testing during 1978 indicated a hydraulic connection between the injection zone in RRGI-4 and MW-1). ${ }^{70}$ The water level trend over the three-year period shows a net water level increase of approximately $2 \mathrm{~m}$. A water level low was recorded in early July 1980; however, water level highs were recorded for the same period in 1979 and 1981. This anomalous fluctuation of high and low water levels does not follow the normal seasonal fluctuation recorded in the other monitor wells, nor does it correspond to geothermal testing. No conclusion has been reached in regard to the water level trend in: MW-1 over the past three years. 


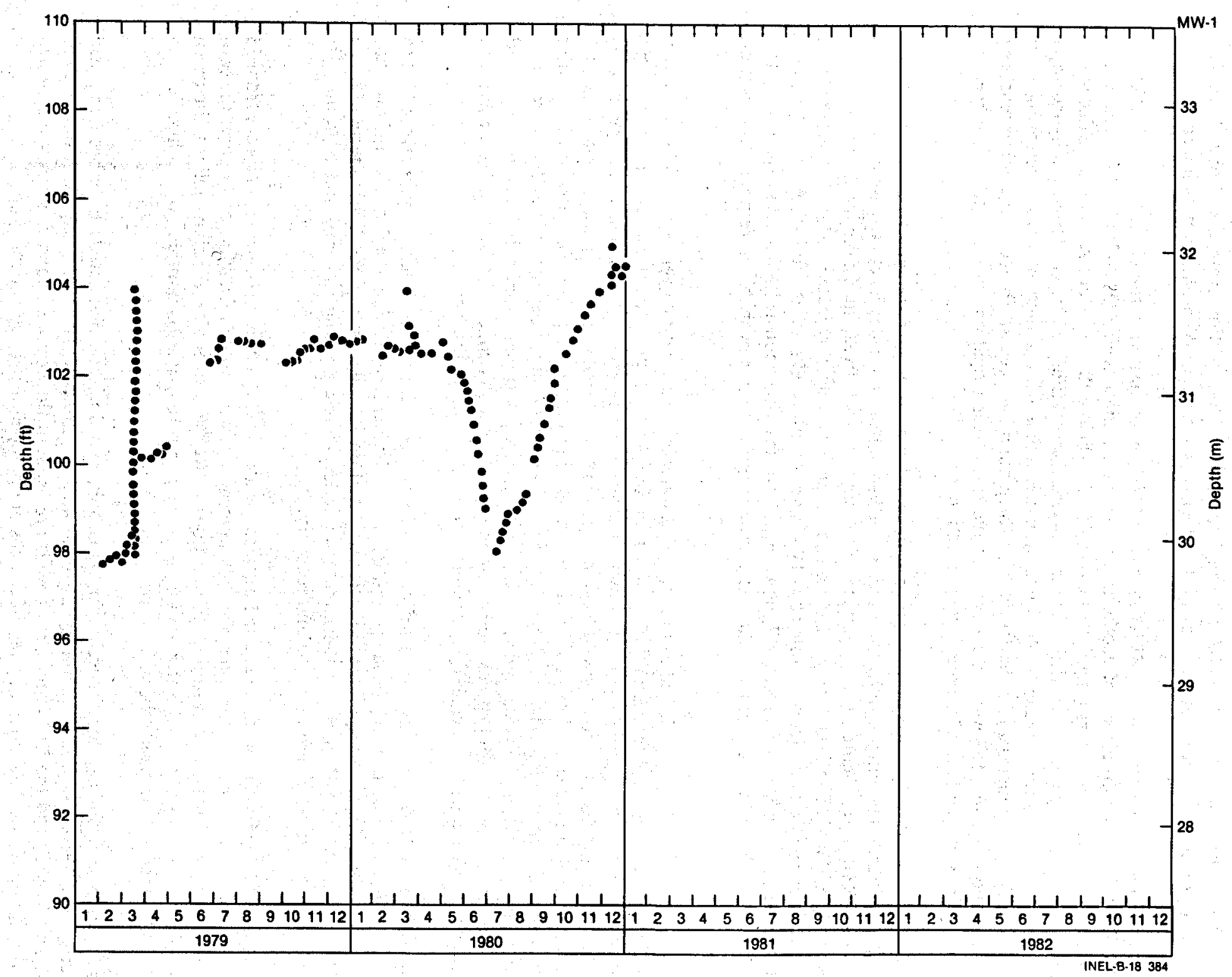

Figure 91. Monitor Well-1 (MW-1) long-term hydrograph. 
Monitor Well-2 (MW-2) was drilled to monitor the effects of injection on the nearby Crook Well and the effects on the shallow aquifer of pumping the Crook Well. MW-2 is a flowing well, drilled to $174 \mathrm{~m}$. Water level data for 1979 were collected sporadically and are not recorded on the long-term hydrograph (Figure 92). A net increase in water level of $2.4 \mathrm{~m}$ over the wellhead was recorded from January 1980 to January 1981. The water level in MW-2 is strongly affected by production from the Crook Well. The limited data preclude a determination of possible effects from geothermal production or injection.

The remaining five monitor wells (MW-3 through MW-7) were located in the vicinity of wells RRGI-6 and RRGI-7 to monitor the effects of geothermal injection. Monitor Well-3 (MW-3) is $152 \mathrm{~m}$ deep with a static water level over three years ranging from 44 to $52.2 \mathrm{~m}$ below the wellhead. A water level decline of approximately $0.75 \mathrm{~m}$ has been recorded over the two-year interval (Figure 93). The long-term hydrograph for MW-3 shows an annual water level fluctuation beginning with a high in April decreasing until September followed by increasing water levels. This fluctuation has been attributed to irrigation pumping from the shallow aquifers followed by recovery at the end of the irrigation season. There have been no effects on MW-3 by geothermal production or injection.

Monitor Well-4 (MW-4) is $305 \mathrm{~m}$ deep with a water level over three years ranging from 0.13 to $11.4 \mathrm{~m}$ below the wellhead. The long-term hydrograph for MW-4 indicates a water level increase in response to injection at RRGI-6 (see Figure 94). A lag time of four days occurs between the beginning of injection and the response in MW-4. The data during injection and water quality data indicate a natural communication between the intermediate aquifer penetrated by $M W-4$ and the injection zone at RRGI-6. A limited connection may exist between MW-4 and RRGI-7; however, response to injection at RRGI-7 is slower and not as great. The water level decline that has followed geothermal injection is probably in response to irrigation pumping.

Monitor Well-5 (MW-5) was drilled to $152 \mathrm{~m}$, with a water level fluctuation over two years between 61.5 and $80.25 \mathrm{~m}$ below the wellhead. A decline in water level of $4.5 \mathrm{~m}$ is shown on the long-term hydrograph for the two-year period (Figure 95). MW-5 shows an annual cycle of ground water fluctuation, peaking at the end of April and declining to its lowest level in September. This well responds to injection into RRGI-6 with a water level decline caused by aquifer distortion related to the elasticity of the matrix of the aquifer system. The decline in water level during injection takes place rapidly at the beginning of injection, remains constant during injection, and rises quickly following injection. A similar response is seen in MW- 6 and MW-7. Aquifer dilation is not expected to be a serious environmental concern. MW-5 shows a rapid and large fluctuation of water level caused by pumping of a nearby irrigation well.

Monitor Well-6 (MW-6) was drilled to $305 \mathrm{~m}$, with a water level fluctuation over two years from 65.7 to $76 \mathrm{~m}$ below the wellhead. The long-term hydrograph shows a water level decline of $4.5 \mathrm{~m}$ over the two-year period (Figure 96). This well responds to injection at RRGI-6 with the same aquifer dilation response seen at MW-5 and MW-7. MW-6 shows the annual water level cycle peaking in April and bottoming in September related to irrigation pumping and recovery.

Monitor Well-7 (MW-7) was drilled to $152 \mathrm{~m}$, with a water level fluctuation over the two years from 75 to $85 \mathrm{~m}$ below the wellhead. The long-term hydrograph shows a net water level decline of $4 \mathrm{~m}$ over the twoyear period (Figure 97). This well responds to injection at RRGI-6 with aquifer dilation similar to that seen in MW-5 and MW-6. The annual water level trend corresponds to irrigation pumping with a high level in March and a low level in September.

Water samples from the monitor wells, BLM, Crook, and domestic plant wells have been collected quarterly since 1980 . Field and laboratory chemical analyses are conducted on samples. Monitor wells MW-1 and MW-2, and the BLM and Crook wells are artesian flowing wells, and samples are collected from the natural flow. The remaining monitor wells are pumped using submersible pumps.

The data collected to date indicate little change in water chemistry over time. However, conclusions on an injection effect may not be made since total duration of the injection pumpings was limited. Collected 


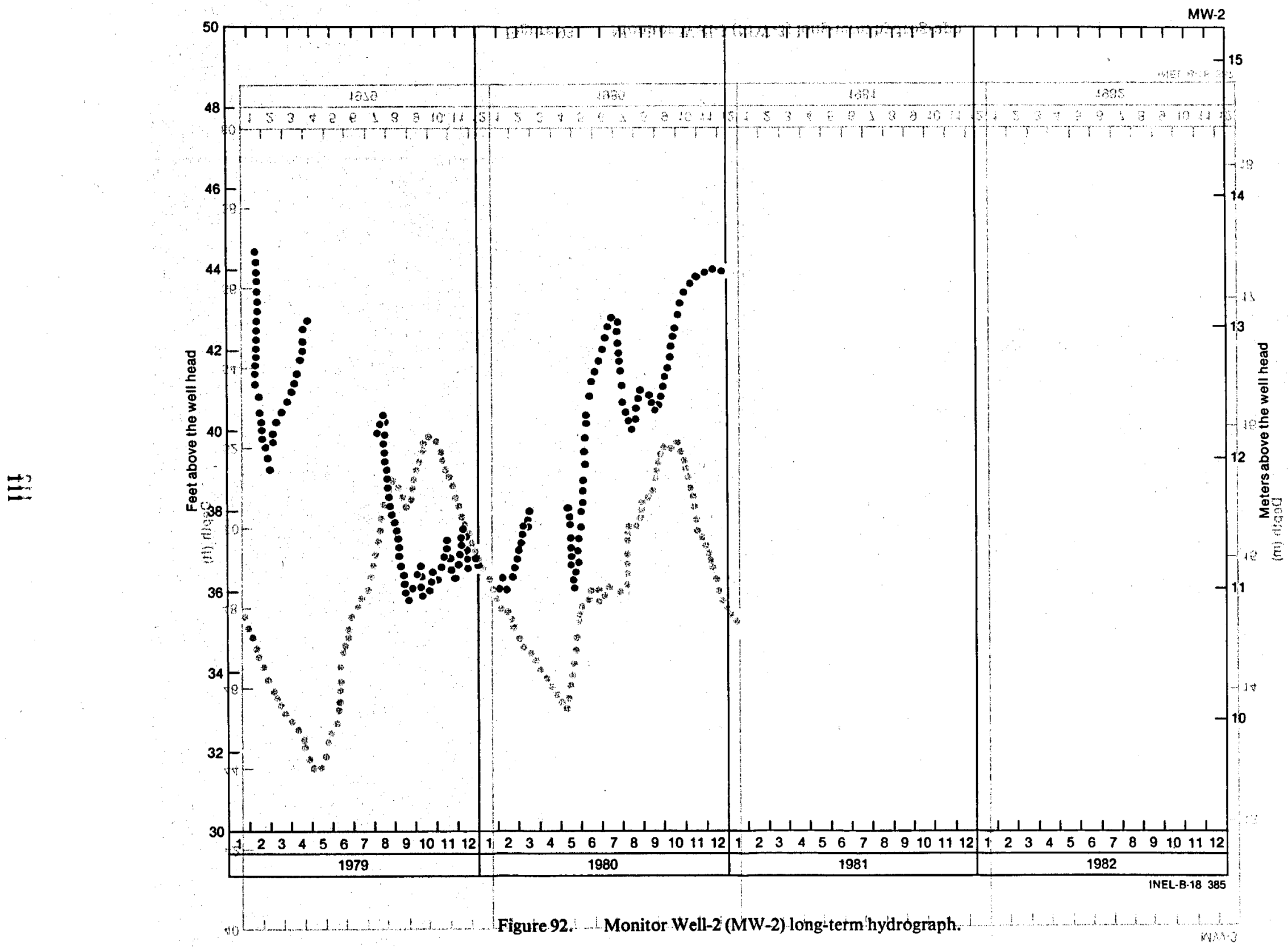




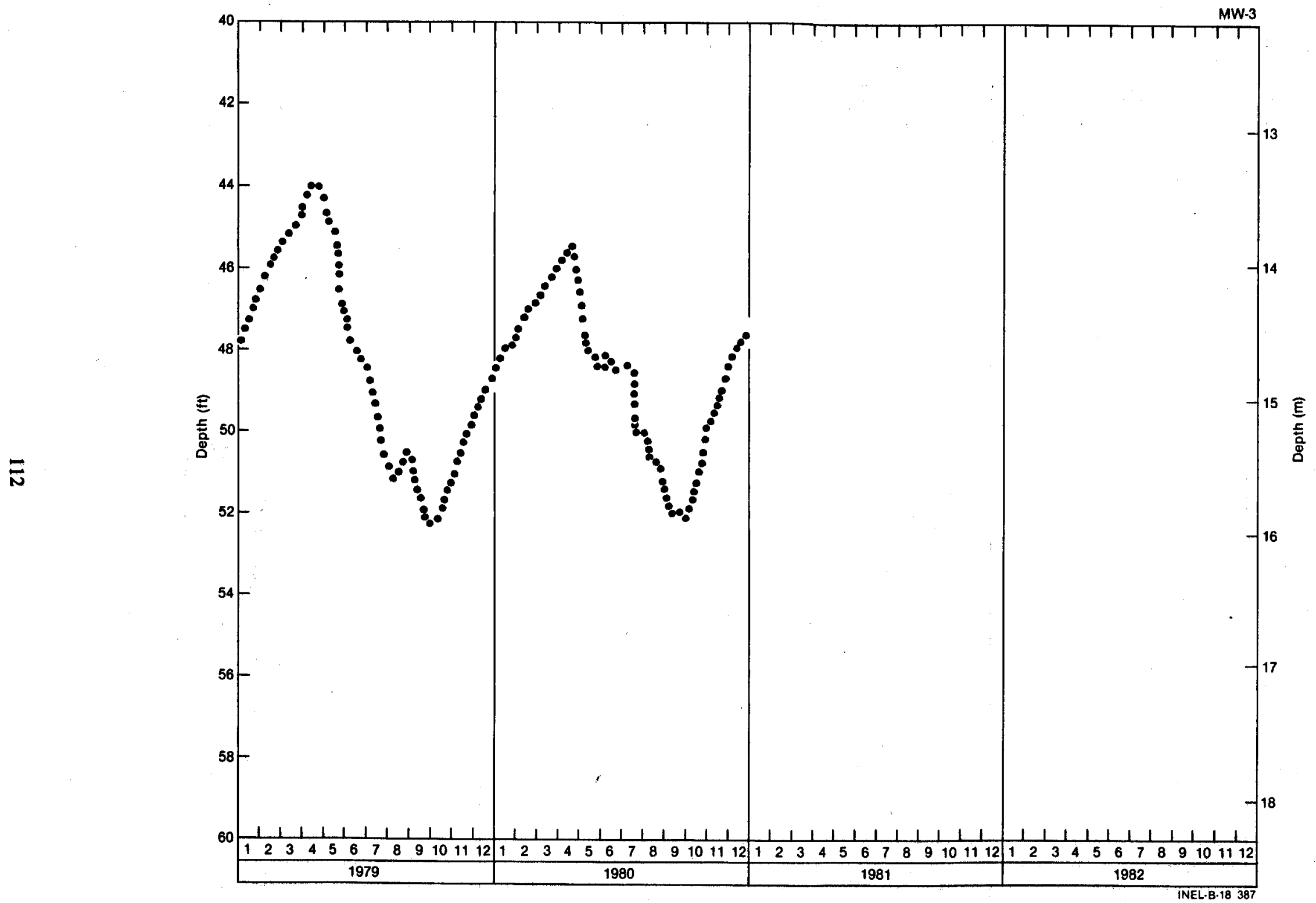

Figure 93. Monitor Well-3 (MW-3) long-term hydrograph. 


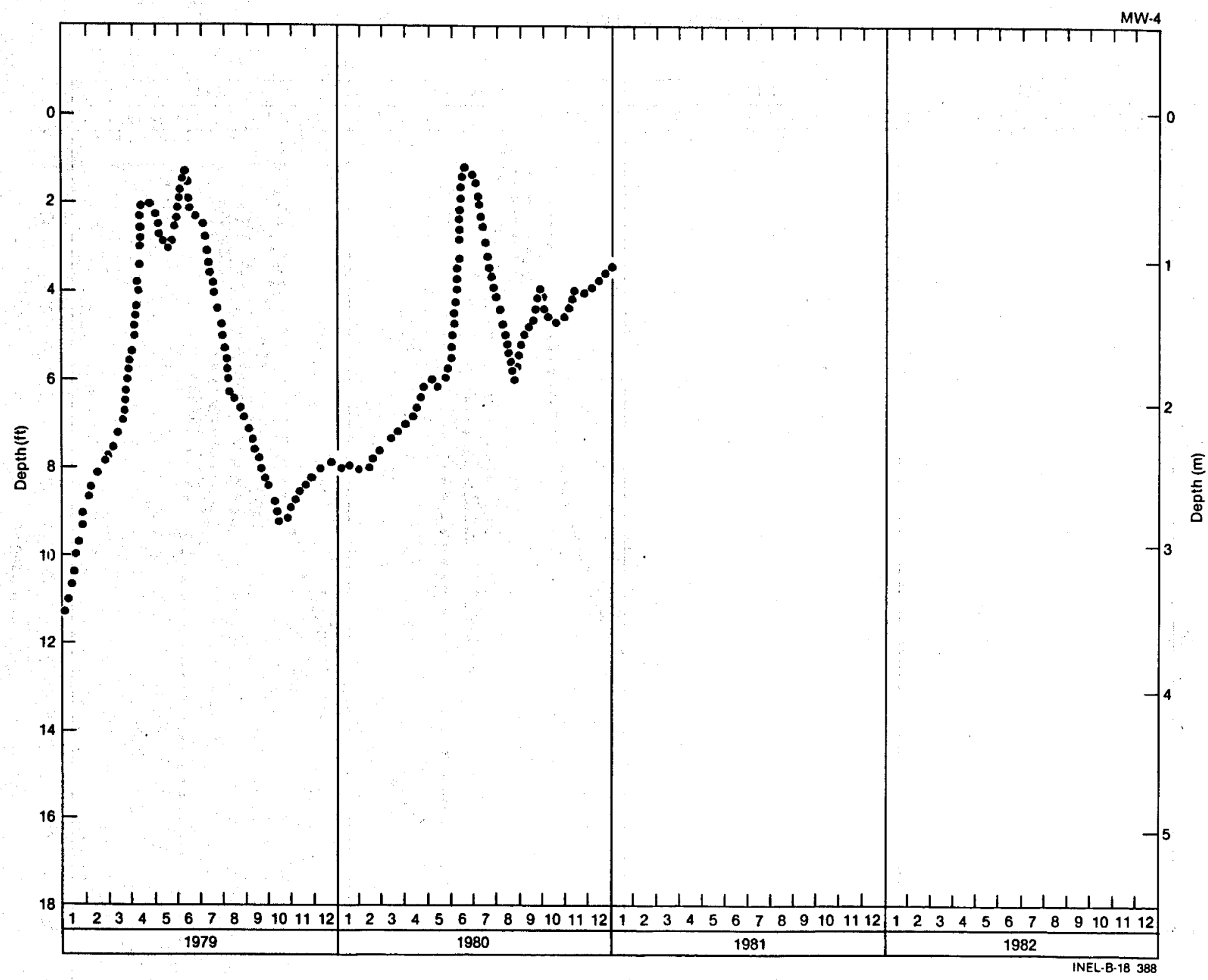

Figure 94. Monitor Well-4 (MW-4) long-term hydrograph. 


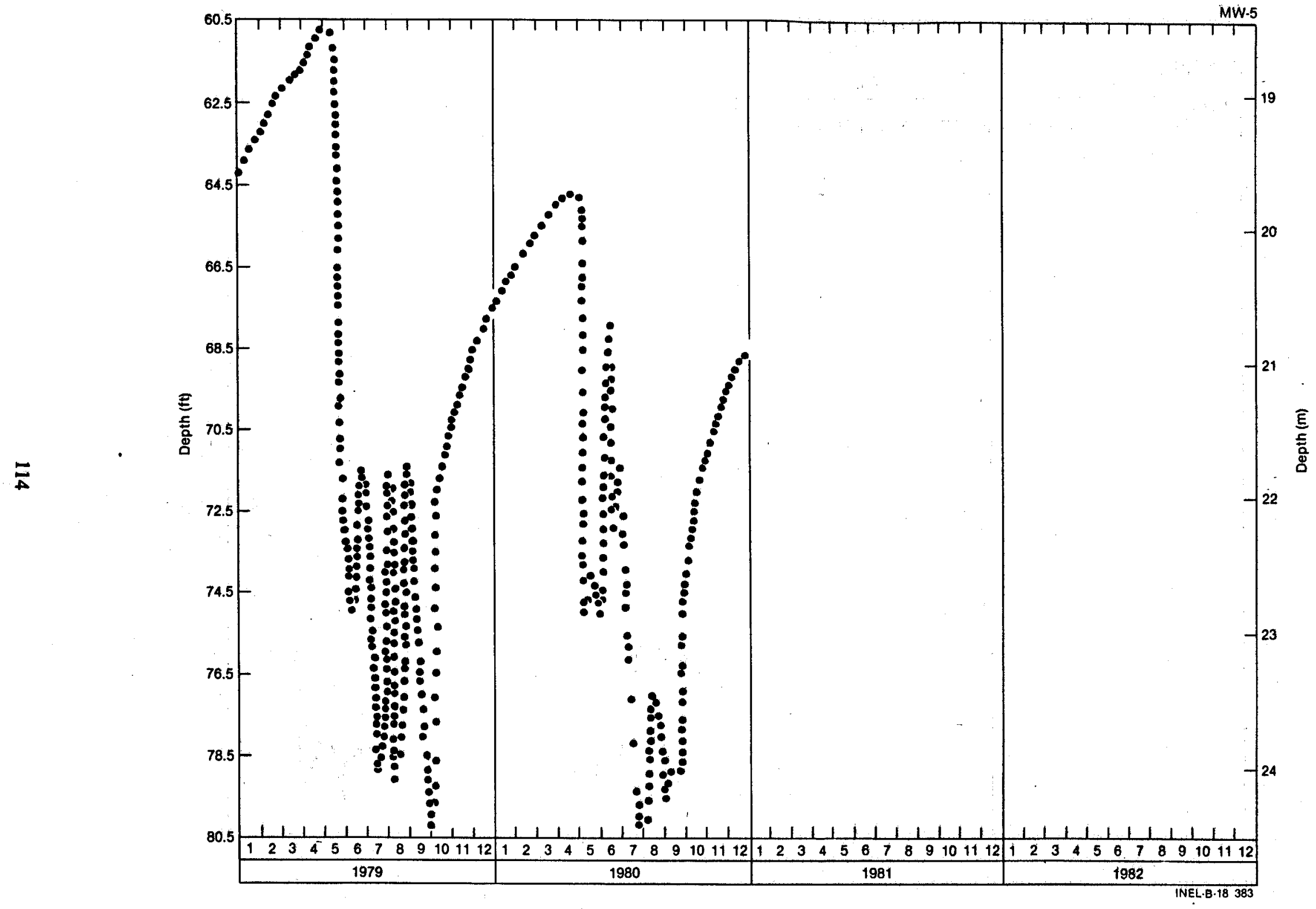

Figure 95. Monitor Well-5 (MW-5) long-term hydrograph. 


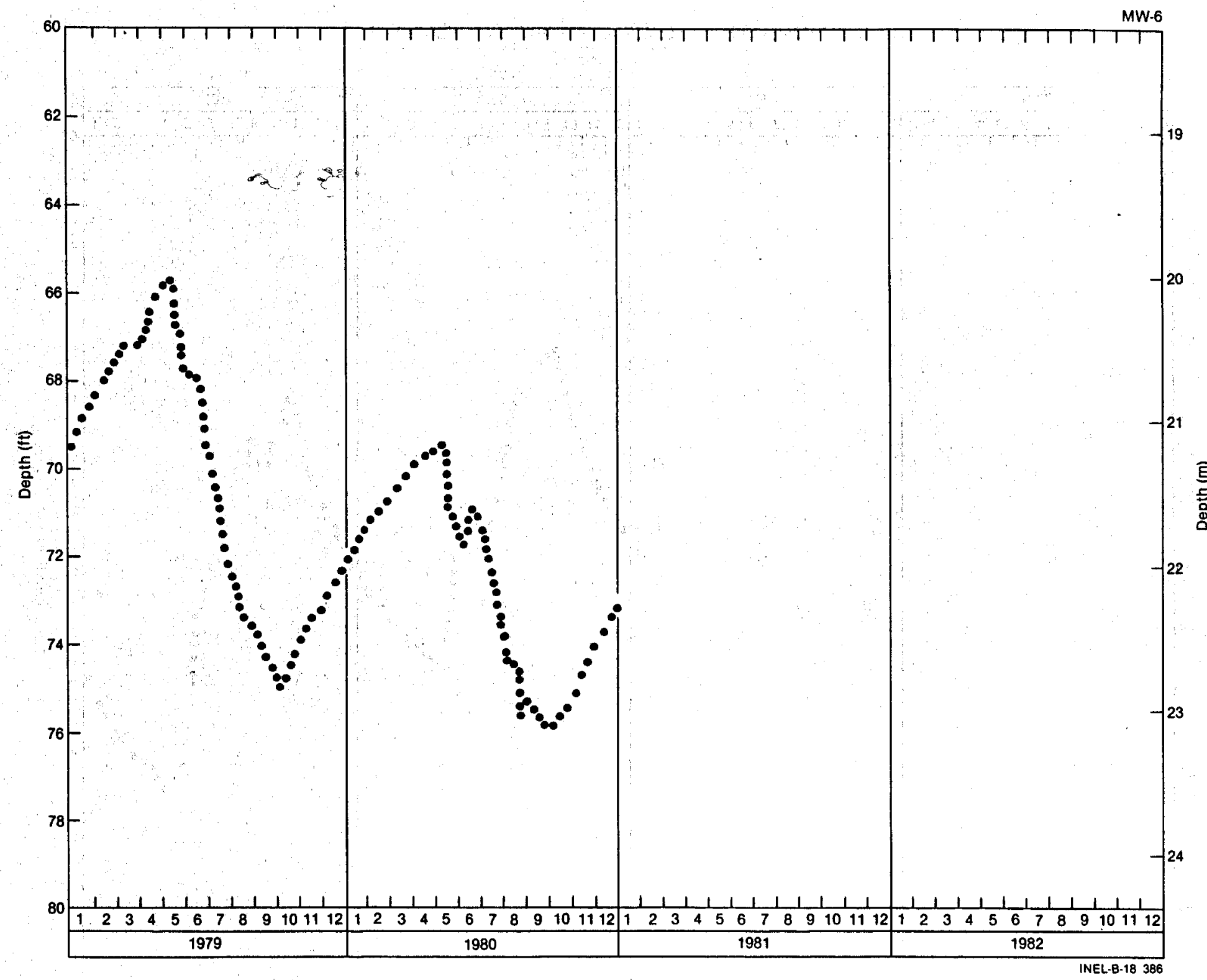

Figure 96. Monitor Well-6 (MW-6) long-term hydrograph. 


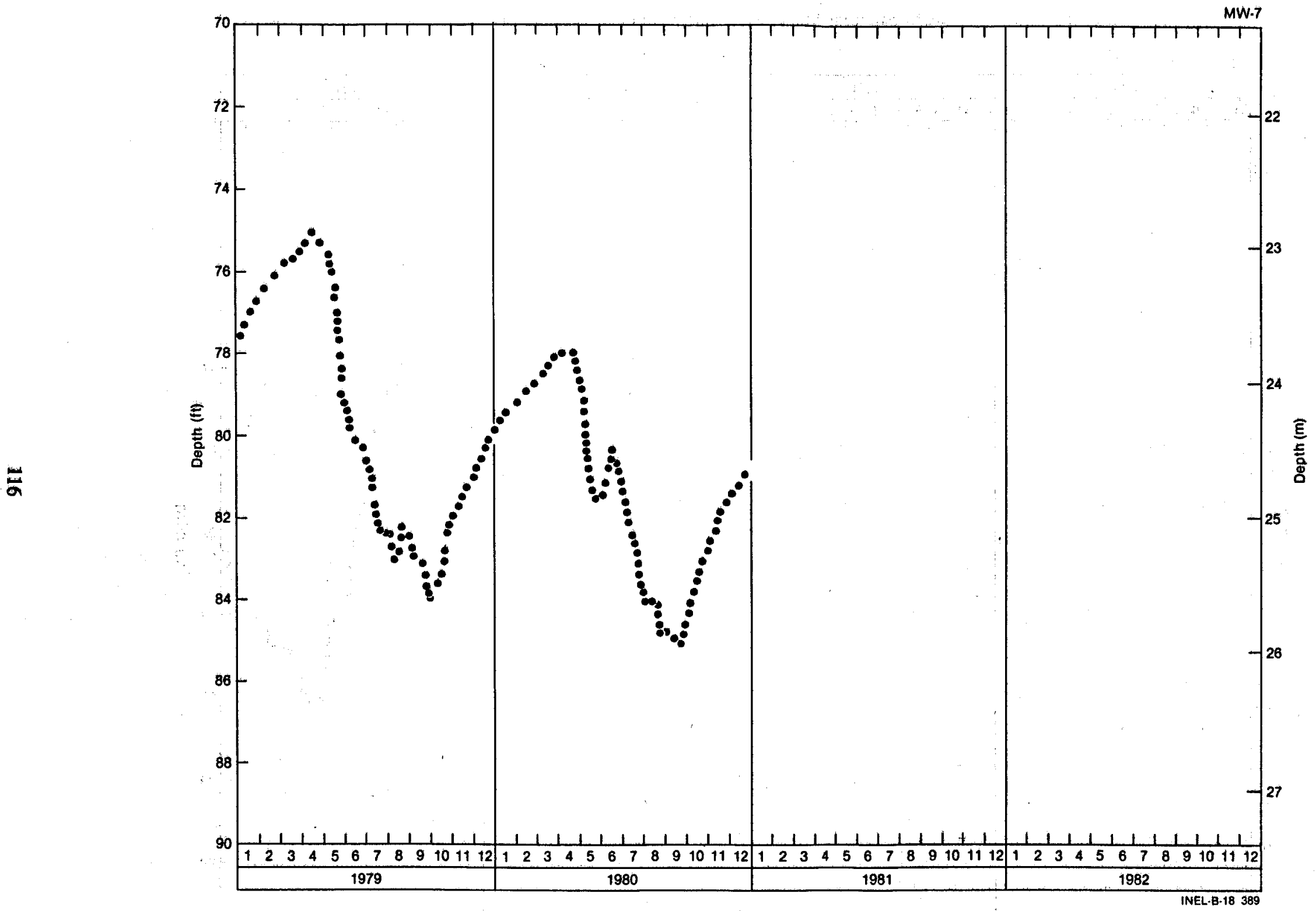

Figure 97. Monitor Well-7 (MW-7) long-term hydrograph. 
water chemistry data provide background information for the monitoring changes after continuous larger volume injection begins. It is expected that more distinctive pressure changes will precede any significant fluid chemistry changes.

\subsection{Conclusions}

Inadequate data exist to define the magnitude or source of recharge to the geothermal system. A tritium analysis of the thermal fluids by the USGS suggests the fluid is at least sixty to seventy years old.

No reproducible reservoir boundaries were determined from well testing. The boundaries evaluated during well testing were determined to be "apparent boundaries" caused by fluid thermal differences. These data, however, conflict with drilling and well test data in the area of RRGP-4, which suggest an extreme decrease in local hydraulic conductivity.

It is apparent from temperature, spinner, and borehole televiewer geophysical logs that production is from specific fractures and porous permeable zones. These fractures are typically found in the contact metamorphic zone. This means that reservoir thickness (h) is a meaningless term, unless considered over a sufficiently large area. In the latter case, it is likely that the effective reservoir thickness is small.

Based on the relatively large areal extent and the possible small effective reservoir thickness, the overall size of geothermal resource cannot be evaluated.

Reservoir drilling and well testing has confirmed the anisotropic nature of the thermal reservoir. The hydraulic conductivity coincidental with the northeast-southwest direction of the Bridge Fault Zone is about two times greater than the orthogonal direction. In either the primary or secondary orientation of hydraulic conductivity, there do not appear to be large changes in reservoir properties (as determined from well testing). However, this conflicts with the drilling data at RRGE-3 and RRGP-4. This may be due to localized areas of lower hydraulic conductivity caused by the nature of a fracture controlled system.

The deep geothermal system is hydraulically connected (perhaps only in localized areas) with the intermediate and shallower potable water system. This has been shown by geochemical sampling, thermal water at the Crook and BLM wells, and hydraulic interference effects determined by well testing. Preliminary data suggest a long range reduction of natural upward geothermal fluid leakage, once well field production commences. However, the short-range effects may be minimal, based on a well test at the Crook Well.

A description of hydrogeologic effects due to injection of spent geothermal fluids has been previously described by Spencer and Callan. ${ }^{70}$ It is apparent that the hydraulic connection in the area of the injection wells is highly anisotropic, possibly due to soft sediment fracturing. 


\section{GEOCHEMISTRY OF THE RAFT RIVER GEOTHERMAL SITE}

\subsection{Introduction}

Geochemical investigations were conducted at the Raft River KGRA for two purposes: (a) to obtain a better understanding of the geothermal reservoir by developing a conceptual model, and (b) to determine potential injection problems from suspended solids and chemical precipitates. A conceptual model is a descriptive picture of the geothermal reservoir, including the sources of recharge, origins of heat, directions of water movement, and sources of dissolved solids. It synthesizes elements from geology, geophysics, geochemistry, and hydrology. Geochemistry was valuable in the development of this conceptual model because of the large differences in dissolved solids contents of recharge from different sources. These differences provided valuable tracers for determining fluid movement.

Injection wells can be clogged by suspended solids in injection fluids, or by chemical precipitates forming in injection formations. This clogging will ruin a well, requiring expensive remedial actions, or the drilling of new wells. Filter studies were carried out to determine the quantity and size distribution of suspended solids in injection fluids. Batch experiments were run to determine the potential for chemical precipitation from mixtures of water from the geothermal wells. Analysis of this information permits the prediction of quantities of solids that would be injected during normal operations of the electrical generating facility.

\subsection{Geochemistry of Ground Water}

A brief discussion of the general water chemistry and the spatial distribution of physical parameters and chemical species is presented first. This information is integral to the development of the conceptual model. The presentation of data is followed by the development of the conceptual model and a discussion of additional information supporting the model.

5.2.1 Water Chemistry. As each of the geothermal wells was completed, it was developed, tested for its yield, and water samples collected for chemical analysis. Additional samples were collected from the wells during pump tests, or during production runs. Seven monitor wells were drilled to follow water level and chemical changes in shallow ground water in the vicinity of the KGRA. In addition to wells drilled in conjunction with the Raft River Site, monitoring of domestic and irrigation wells in the area has been conducted by the Idaho Department of Water Resources. Chemical analyses from these wells have been compiled into a computerized data base to permit easy access to the data. Appendix $D$ contains the data currently available for the geothermal and monitor wells at the KGRA.

Table 32 shows a selected analysis from the geothermal and monitor wells at the KGRA as well as from some of the surrounding private wells. These data are averages of the most consistent chemical analyses from each of the wells, and were selected on the basis of yielding results close to electrical neutrality. For the seven geothermal wells, the seven monitor wells, and the three United States Geological Survey (USGS) wells, the temperature data is the bottom hole measurement. Other water temperatures are as measured from well discharge.

All the deep geothermal wells have sodium chloride type waters, based on the predominant cation and anion in terms of milliequivalents per liter (meq/L). The sodium ranges from 83 to $91 \%$ of the cations, and chloride from 92 to $99 \%$ of the anions. The waters are all low in alkalinity, ranging from 26 to $60 \mathrm{mg} / \mathrm{L}$ as $\mathrm{CaCO}_{3}$. There is a great deal of variation in the total amount of dissolved solids among the wells.

Wells RRGE-1, -2 , and RRGP-5 are similar in the content of dissolved solids, temperature, and chemical character. Contents of dissolved chemical species are relatively low, with specific conductivities ranging from $2500-2800 \mu \mathrm{S}$. These wells have the highest fluoride contents, with greater than $7 \mathrm{mg} / \mathrm{L}$ in all three. 
Table 32. Selected physical and chemical data from wells

\begin{tabular}{|c|c|c|c|c|c|c|c|c|c|c|c|c|c|c|c|c|c|c|}
\hline \multirow[b]{2}{*}{ Hell } & \multirow{2}{*}{$\begin{array}{l}\text { Well } \\
\text { Depth } \\
\text { (m) }\end{array}$} & \multirow{2}{*}{$\begin{array}{l}\text { Casing } \\
\text { Depth } \\
\text { (m) } \\
\end{array}$} & \multirow[b]{2}{*}{$\begin{array}{c}\text { Temperature } \\
\left({ }^{\circ} \mathrm{C}\right) \\
\end{array}$} & \multirow{2}{*}{$\begin{array}{c}\text { Specific } \\
\text { Conductivity } \\
\quad(18) \\
\end{array}$} & \multirow[b]{2}{*}{$\mathrm{pH}$} & \multirow[b]{2}{*}{$\mathrm{Ca}^{+2}$} & \multirow{3}{*}{$\underline{\mu_{R}{ }^{+2}}$} & \multirow[b]{2}{*}{$\underline{\mathrm{sr}}+2$} & \multicolumn{5}{|c|}{$\begin{array}{c}\text { Chemical Concentrations } \\
(\mathrm{mg} / \mathrm{L})\end{array}$} & \multirow[b]{2}{*}{$\mathrm{CI}^{-}$} & \multirow[b]{2}{*}{$\underline{\mathbf{F}^{-}}$} & \multirow[b]{2}{*}{$\mathrm{SiO}_{2}$} & \multicolumn{2}{|c|}{$\begin{array}{c}\text { Calculated } \\
\text { Temperatures } \\
\text { (*C) } \\
\end{array}$} \\
\hline & & & & & & & & & $\underline{\mathrm{Na}^{+}}$ & $\underline{\mathbf{R}^{+}}$ & $\mathrm{Li}^{+}$ & $\mathrm{HCO}_{3}^{-}$ & $\mathrm{so}_{4}^{-2}$ & & & & $\mathrm{SiO}_{2}$ & $\mathrm{Na}-\mathrm{K}-\mathrm{Ca}$ \\
\hline \multicolumn{18}{|l|}{ Geothermal } & \\
\hline $\begin{array}{l}\text { RRGE-1 } \\
\text { RRGE-2 } \\
\text { RRGE-3 } \\
\text { RRGP-4 } \\
\text { RRGP-5 } \\
\text { RRGI-6 } \\
\text { RRGI-7 }\end{array}$ & $\begin{array}{l}1521 \\
1994 \\
1789 \\
1654 \\
1497 \\
1176 \\
1185\end{array}$ & $\begin{array}{r}1105 \\
1289 \\
1293 \\
1054 \\
1039 \\
509 \\
623\end{array}$ & $\begin{array}{r}141 \\
144 \\
149 \\
142 \\
135 \\
71 \\
78\end{array}$ & $\begin{array}{rr}2 & 800 \\
2 & 500 \\
8 & 000 \\
4 & 050 \\
2 & 700 \\
10 & 800 \\
12 & 000\end{array}$ & $\begin{array}{l}7.3 \\
7.1 \\
6.9 \\
7.2 \\
7.5 \\
7.2 \\
--\end{array}$ & $\begin{array}{r}56 \\
42 \\
224 \\
86 \\
41 \\
171 \\
350\end{array}$ & $\begin{array}{l}0.6 \\
0.1 \\
0.5 \\
0.1 \\
0.1 \\
1.4 \\
1.5\end{array}$ & $\begin{array}{l}1.4 \\
1.2 \\
5.2 \\
6.4 \\
1.2 \\
8.0 \\
--\end{array}$ & $\begin{array}{r}455 \\
441 \\
1194 \\
753 \\
484 \\
2200 \\
2200\end{array}$ & $\begin{array}{r}34 \\
38 \\
105 \\
-31 \\
32 \\
--\end{array}$ & $\begin{array}{l}1.6 \\
1.1 \\
3.1 \\
3.1 \\
1.6 \\
5.1 \\
--\end{array}$ & $\begin{array}{l}41 \\
41 \\
44 \\
42 \\
35 \\
73 \\
32\end{array}$ & $\begin{array}{l}36 \\
53 \\
60 \\
40 \\
60 \\
64\end{array}$ & $\begin{array}{r}776 \\
708 \\
2260 \\
1400 \\
800 \\
3640 \\
4000\end{array}$ & $\begin{array}{l}7.9 \\
8.7 \\
4.9 \\
6.3 \\
7.2 \\
5.7 \\
4.9\end{array}$ & $\begin{array}{l}121 \\
131 \\
158 \\
104 \\
133 \\
94 \\
83\end{array}$ & $\begin{array}{l}148 \\
153 \\
164 \\
136 \\
154 \\
134 \\
127\end{array}$ & $\begin{array}{l}173 \\
183 \\
187 \\
169 \\
114 \\
--\end{array}$ \\
\hline \multicolumn{19}{|l|}{ Monitor } \\
\hline $\begin{array}{l}M W-1 \\
M W-2 \\
M W-3 \\
M W-4 \\
M W-5 \\
M W-6 \\
M W-7\end{array}$ & $\begin{array}{l}399 \\
174 \\
153 \\
305 \\
152 \\
305 \\
152\end{array}$ & $\begin{array}{l}369 \\
154 \\
140 \\
225 \\
124 \\
274 \\
140\end{array}$ & $\begin{array}{r}-- \\
106 \\
71 \\
98 \\
29 \\
44 \\
35\end{array}$ & $\begin{array}{rl}11 & 400 \\
4 & 400 \\
6 & 200 \\
7 & 800 \\
2 & 200 \\
7 & 600 \\
2 & 300\end{array}$ & $\begin{array}{l}7.6 \\
7.4 \\
7.5 \\
7.7 \\
7.6 \\
7.3 \\
7.6\end{array}$ & $\begin{array}{l}215 \\
125 \\
155 \\
160 \\
107 \\
207 \\
95\end{array}$ & $\begin{array}{c}0.4 \\
0.5 \\
6.3 \\
0.6 \\
25 \\
2.4 \\
20\end{array}$ & $\begin{array}{l}6.3 \\
3.6 \\
1.9 \\
1.4 \\
0.9 \\
1.4 \\
0.9\end{array}$ & $\begin{array}{r}2200 \\
1000 \\
1400 \\
1520 \\
280 \\
1570 \\
333\end{array}$ & $\begin{array}{l}30 \\
25 \\
65 \\
31 \\
14 \\
56 \\
14\end{array}$ & $\begin{array}{l}3.7 \\
2.5 \\
3.0 \\
3.7 \\
0.3 \\
3.1 \\
0.6\end{array}$ & $\begin{array}{r}25 \\
26 \\
47 \\
27 \\
120 \\
50 \\
125\end{array}$ & $\begin{array}{l}66 \\
57 \\
60 \\
53 \\
27 \\
73 \\
33\end{array}$ & $\begin{array}{r}3680 \\
1740 \\
2460 \\
2610 \\
610 \\
2770 \\
650\end{array}$ & $\begin{array}{l}3.4 \\
5.4 \\
5.4 \\
5.6 \\
0.6 \\
4.9 \\
1.1\end{array}$ & $\begin{array}{l}80 \\
87 \\
60 \\
67 \\
34 \\
85 \\
40\end{array}$ & $\begin{array}{l}125 \\
130 \\
111 \\
116 \\
-- \\
--\end{array}$ & $\begin{array}{l}110 \\
128 \\
160 \\
123 \\
-- \\
--\end{array}$ \\
\hline \multicolumn{19}{|c|}{ USGS Monítor } \\
\hline $\begin{array}{l}\text { USGS-1 } \\
\text { USGS }-2 \\
\text { USGS-3 }\end{array}$ & $\begin{array}{l}336 \\
243 \\
434\end{array}$ & $\begin{array}{l}64 \\
60\end{array}$ & $\begin{array}{l}28 \\
55 \\
89\end{array}$ & $\begin{array}{l}7400 \\
1960 \\
5900\end{array}$ & $\begin{array}{l}7.8 \\
7.7 \\
7.7\end{array}$ & $\begin{array}{r}230 \\
51 \\
57\end{array}$ & $\begin{array}{l}2.5 \\
4.0 \\
0.5\end{array}$ & $\begin{array}{l}1.7 \\
0.3 \\
2.0\end{array}$ & $\begin{array}{r}1500 \\
370 \\
1270\end{array}$ & $\begin{array}{r}200 \\
34 \\
14\end{array}$ & $\begin{array}{l}0.9 \\
6.6 \\
1.7\end{array}$ & $\begin{array}{r}100 \\
216 \\
77\end{array}$ & $\begin{array}{l}45 \\
55 \\
54\end{array}$ & $\begin{array}{r}2800 \\
520 \\
2040\end{array}$ & $\begin{array}{l}3.2 \\
2.5 \\
4.8\end{array}$ & $\begin{array}{l}85 \\
88 \\
54\end{array}$ & $\begin{array}{l}-- \\
130 \\
105\end{array}$ & $\begin{array}{l}-- \\
182 \\
103\end{array}$ \\
\hline \multicolumn{19}{|c|}{ Other Geotherma ${ }^{b}$} \\
\hline $\begin{array}{l}\text { BLMC } \\
\text { CROOKd }\end{array}$ & $\begin{array}{l}126 \\
165\end{array}$ & - & $\begin{array}{l}93 \\
97\end{array}$ & $\begin{array}{l}3000 \\
5800\end{array}$ & $\begin{array}{l}7.4 \\
7.7\end{array}$ & $\begin{array}{r}44 \\
130\end{array}$ & $\begin{array}{l}0.7 \\
0.8\end{array}$ & $\begin{array}{l}1.5 \\
2.8\end{array}$ & $\begin{array}{r}577 \\
1020\end{array}$ & $\begin{array}{l}21 \\
32\end{array}$ & $\begin{array}{l}1.4 \\
2.6\end{array}$ & $\begin{array}{l}49 \\
34\end{array}$ & $\begin{array}{l}65 \\
56\end{array}$ & $\begin{array}{r}890 \\
1750\end{array}$ & $\begin{array}{l}7.6 \\
6.2\end{array}$ & $\begin{array}{l}74 \\
86\end{array}$ & $\begin{array}{l}120 \\
127\end{array}$ & $\begin{array}{l}144 \\
138\end{array}$ \\
\hline \multicolumn{19}{|l|}{ Private } \\
\hline $\begin{array}{l}15 S-26 \mathrm{E} \\
23 \mathrm{ABD} 1 \\
15 \mathrm{~S}-26 \mathrm{E} \\
23 \mathrm{DDD} 1\end{array}$ & $\begin{array}{r}110 \\
78\end{array}$ & - & $\begin{array}{l}29 \\
42\end{array}$ & $\begin{array}{l}4500 \\
3900\end{array}$ & $\begin{array}{l}7.6 \\
7.1\end{array}$ & $\begin{array}{l}97 \\
104\end{array}$ & $\begin{array}{l}5.0 \\
8.0\end{array}$ & -- & $\begin{array}{l}766 \\
644\end{array}$ & $\begin{array}{l}20 \\
18\end{array}$ & $\begin{array}{l}1.9 \\
1.1\end{array}$ & $\begin{array}{l}155 \\
168\end{array}$ & $\begin{array}{l}96 \\
57\end{array}$ & $\begin{array}{l}1270 \\
1100\end{array}$ & $\begin{array}{l}5.1 \\
4.5\end{array}$ & $\begin{array}{l}61 \\
58\end{array}$ & -- & -- \\
\hline $\begin{array}{l}\text { a. Depth } \\
\text { b. Temper } \\
\text { c. This } \\
\text { d. This w }\end{array}$ & $\begin{array}{l}\text { bottom } \\
\text { re meas } \\
\text { was dt } \\
\text { was pr }\end{array}$ & $\begin{array}{l}\text { of casing } \\
\text { ured at } \\
\text { illed in }\end{array}$ & $\begin{array}{l}\text { or to first pe } \\
\text { rface. } \\
\text { he } 1920^{\circ} \text { s and } \\
\text { whed by Crank, }\end{array}$ & $\begin{array}{l}\text { called the } \\
\text { ad is referr }\end{array}$ & idg & 11 & he & . & & & & & & & & & $\because$ & \\
\hline
\end{tabular}


Wells RRGI-6 and -7 have very high dissolved solids contents, predominantly sodium and chloride, and are relatively low in fluoride, having 5.7 and $4.9 \mathrm{mg} / \mathrm{L}$ for RRGI-6 and -7 , respectively. The temperature of these wells is also much lower than that of the others, being almost half that of the maximum measured in RRGE-3.

Wells RRGE-3 and RRGP-4 are intermediate in dissolved solids between the wells along the Bridge Fault, and those in the central valley area. Well RRGE-3 has the hottest downhole temperature at $149^{\circ} \mathrm{C}$.

The chemistry of the monitor well network is covered by Spencer and Callan, 70 and of the general shallow ground water by Walker et al. 72

Geochemical thermometers ${ }^{73}$ give temperatures that fall within a fairly narrow range, and are close to temperatures measured in the geothermal wells. Calculated silica temperatures indicate maximum reservoir temperatures from 10 to $20^{\circ} \mathrm{C}$ warmer than so far encountered in wells. Temperatures calculated from the $\mathrm{Na}-\mathrm{K}-\mathrm{Ca}$ geothermometer generally give temperatures from 30 to $40^{\circ} \mathrm{C}$ warmer than those measured in wells. The general agreement between measured and calculated temperatures indicates that the wells are probably tapping about the hottest water available.

5.2.2 Distribution of Physical Parameters and Chemical Species. The spatial distribution of physical parameters and chemical species is shown by contouring data collected from wells. Contouring requires subjective interpretation of data. Figure 98 shows the areal distribution in specific conductance $(\mathrm{SpC})$ of shallow ground water (depth $<200 \mathrm{~m}$ ) in the vicinity of the Raft River KGRA. Background conductance levels are less than $2000 \mu \mathrm{S}$, with some wells having conductivities as low as $1000 \mu \mathrm{S}$. Specific conductivities of ground water are higher over the geothermal resource, reaching a maximum of about $6000 \mu \mathrm{S}$ southwest of the river. This same area also exhibits the highest temperatures for shallow ground water (Figure 99). The BLM well, to the northwest, is also quite warm, but is separated from the warm waters near the center of the area by cooler waters. The zone of high conductivity and temperature in the ground water, southeast of the river, indicates a plume of geothermal water rising above the hot zone and mixing with shallow ground waters.

A cross section through the Raft River KGRA (location shown as A-A' in Figure 98) shows variations in chemistry and temperature with depth. Wells projected onto the cross section produce some variations due to lateral variations in chemistry. Well RRGE-2 is dashed in the cross section because of its distance from the cross section. It was included to add additional information at depth.

Chemical and physical parameter cross sections generally show one of two patterns. One type of pattern is exhibited by SpC (Figure 100), with a plume of high conductivity waters moving in from the southeast. This plume moves upwards to near the surface at MW-1. A second pattern is shown by temperature measurements (Figure 101). These temperatures are from downhole temperature logs for the geothermal and monitor wells, and from measured water temperatures for the other wells. Temperature contours show a different pattern, with contours dipping steeply to the southeast and approaching the surface near the Crook and BLM wells.

Chemical species tend to show one of these two patterns. Silica (Figure 102), which is controlled by the temperature effects on the solubility of quartz, closely follows the appearance of the temperature cross section. Other dissolved species closely follow the appearance of the conductivity cross section. Calcium, for example, also shows the plume of high concentrations moving in from the southeast (Figure 103). Fluoride shows a unique distribution in cross. section (Figure 104). While a plume from the southeast is still present, concentrations of fluoride in this plume are lower than in immediately surrounding areas. The highest fluoride concentrations occur in deep geothermal waters to the northwest.

Fluorite commonly controls the maximum fluoride concentrations in hydrothermal waters, ${ }^{74}$ and may be controlling the low fluoride concentrations in the southeast of the KGRA. Figure 105 shows a plot of calcium versus fluoride, with a dashed line representing the expected calcium and fluoride concentrations in equilibrium with fluorite at about $125^{\circ} \mathrm{C}$. 75 Because of temperature differences and variations in ion 
$C^{\prime}$

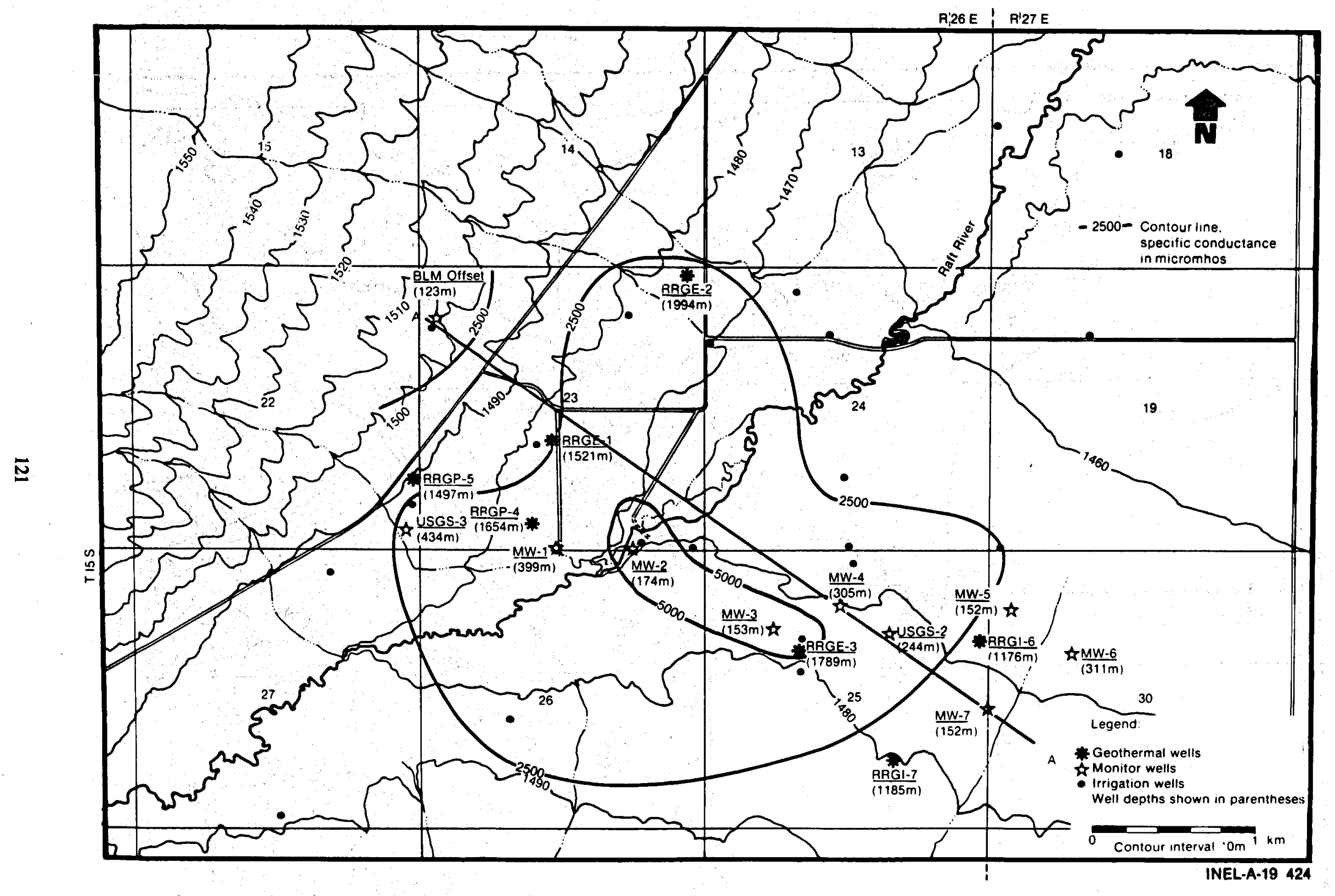

Figure 98. Specific conductance of shallow ( $<200 \mathrm{~m})$ ground water in the vicinity of the Raft River KGRA. 


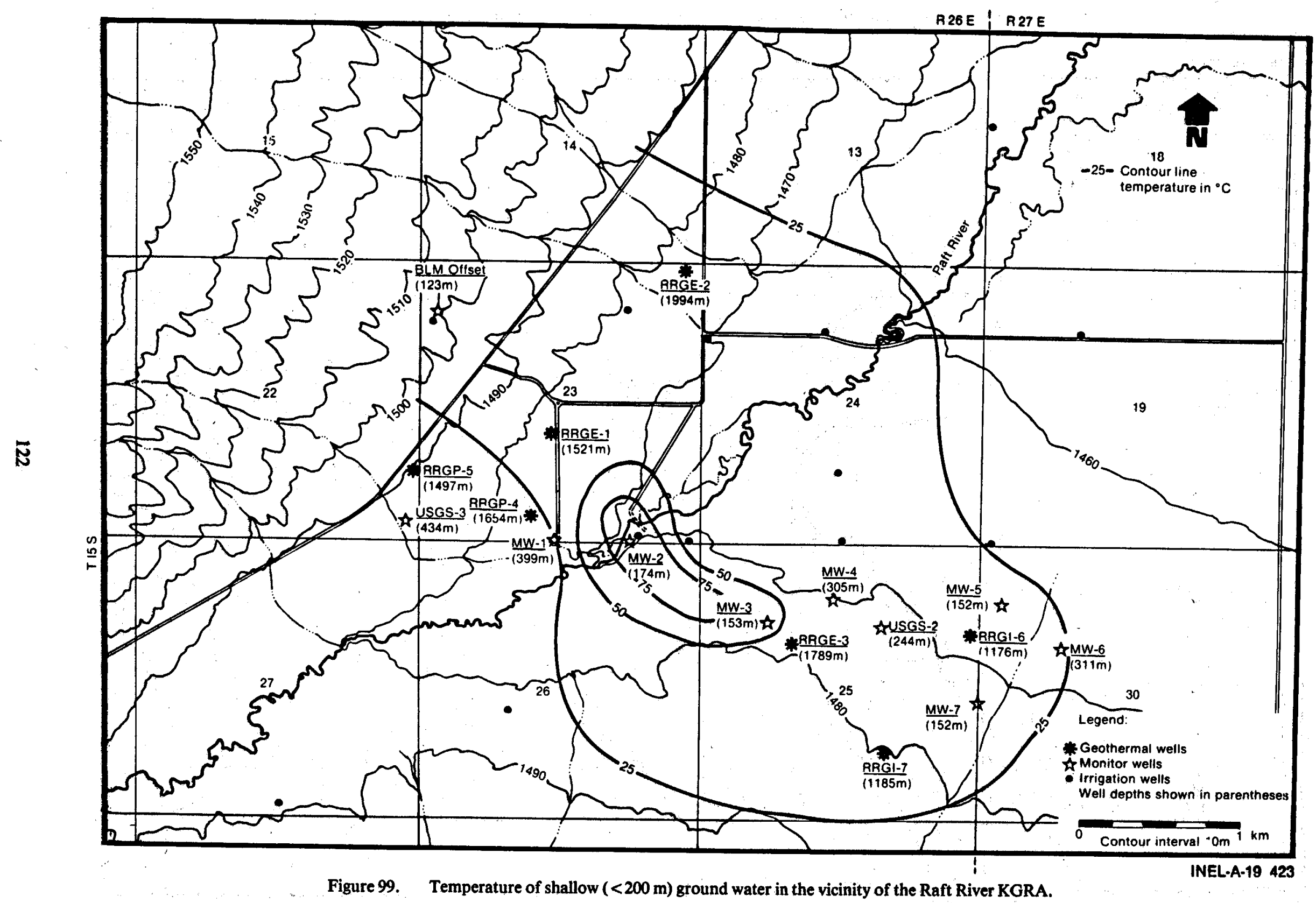

C 


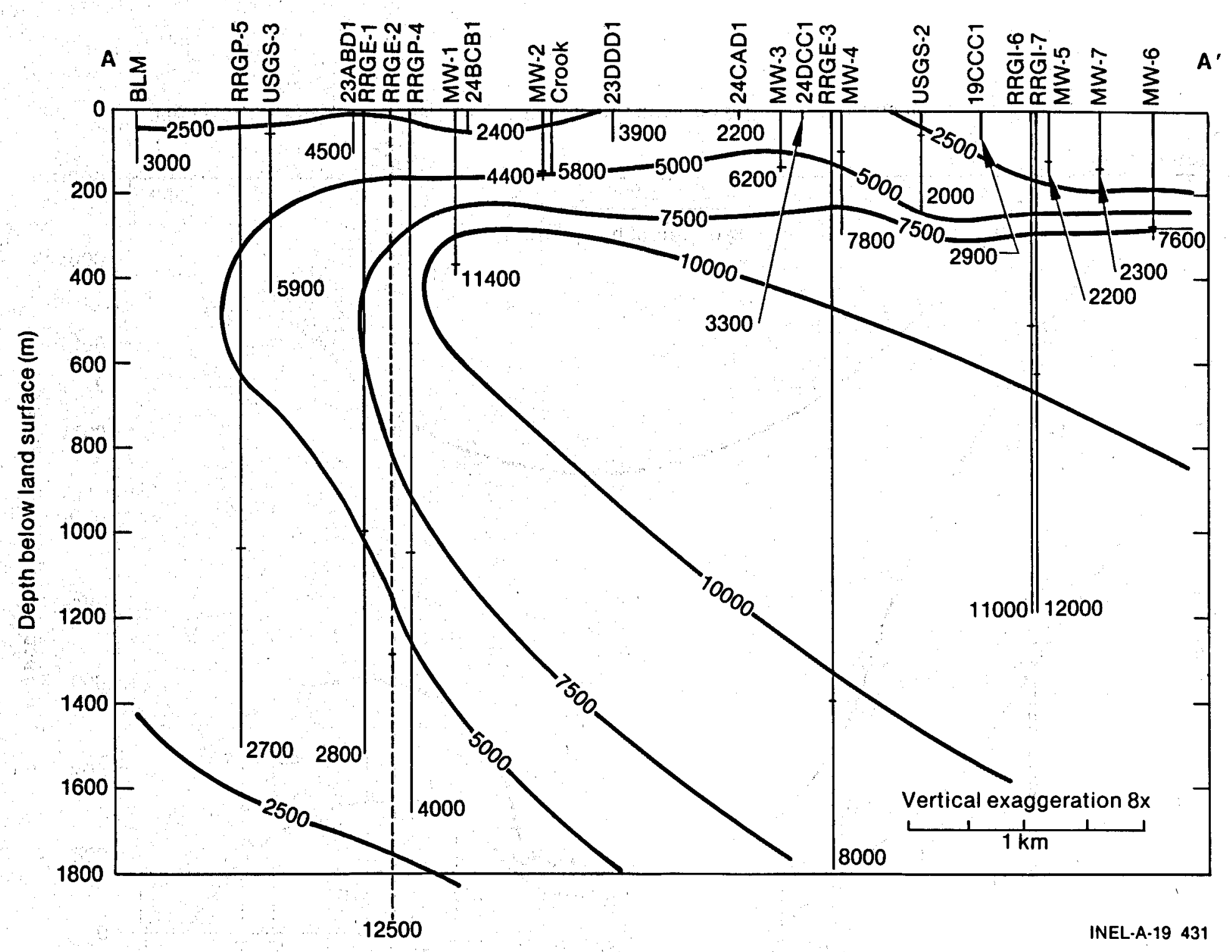

Figure 100. Cross section through the Raft River KGRA showing distribution of specific conductance of ground water. (Location of Section A - A is shown in Figure 1.) 


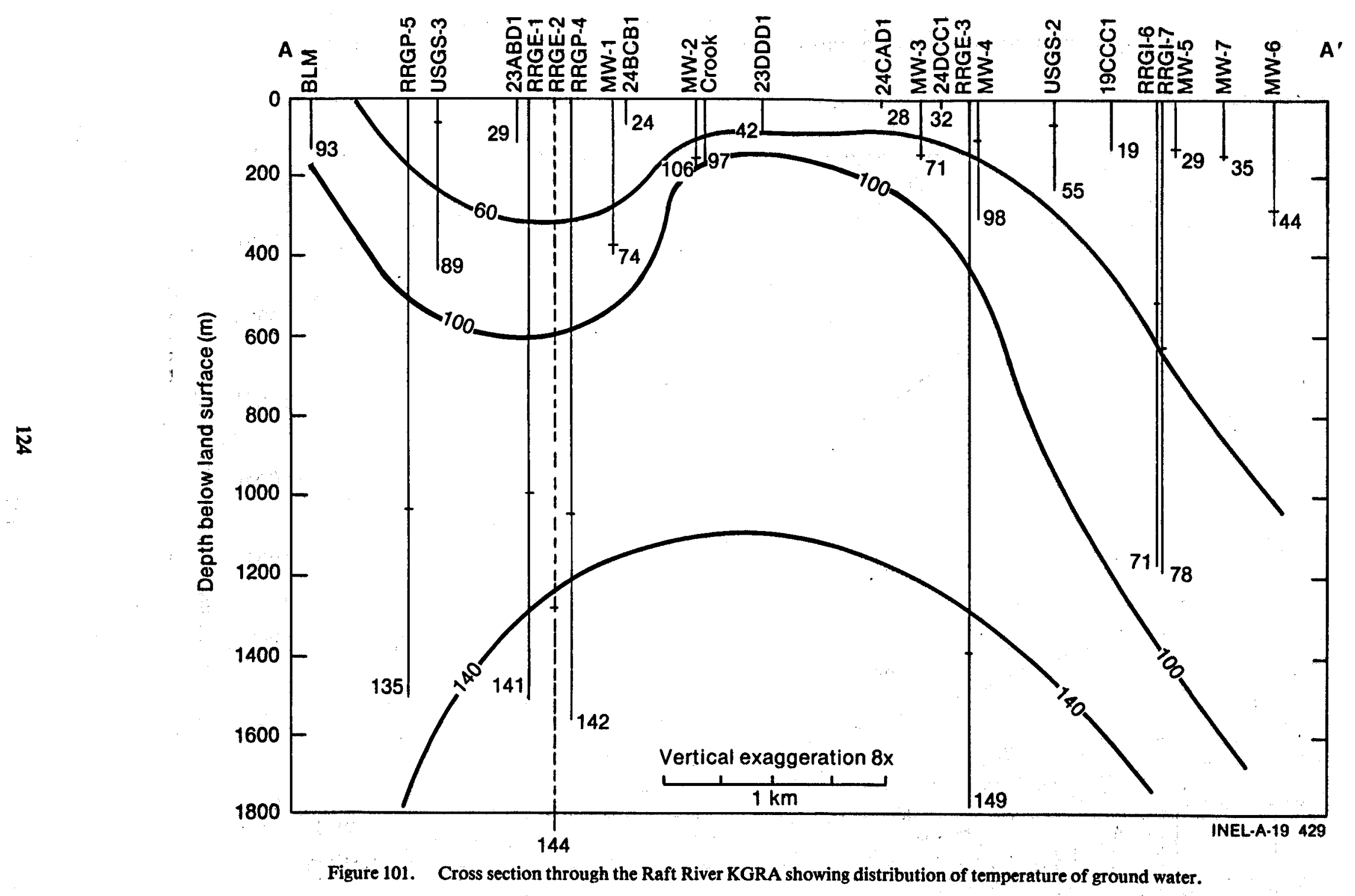




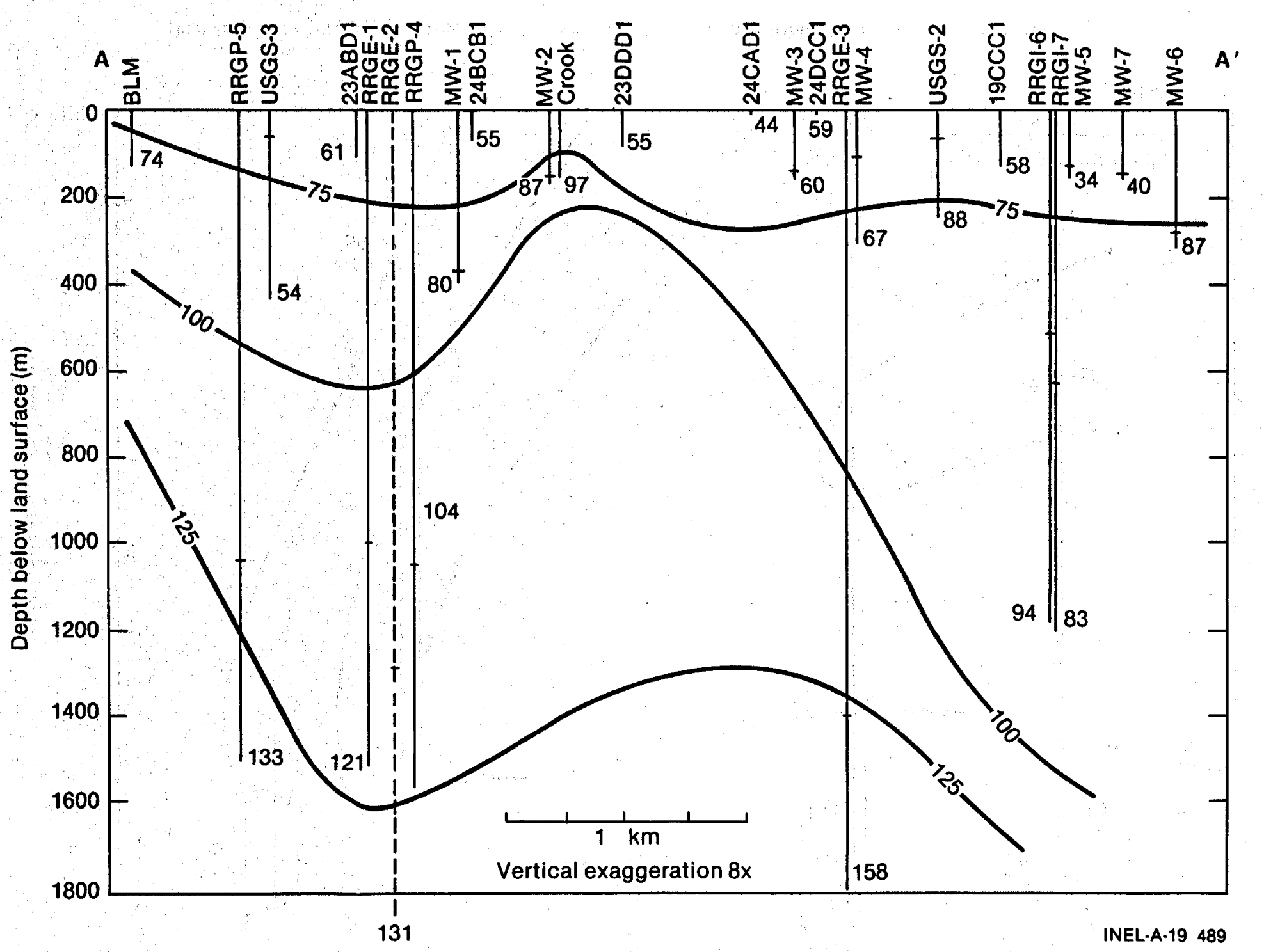

Figure 102. Cross section through the Raft River KGRA showing distribution of silica in ground water. 


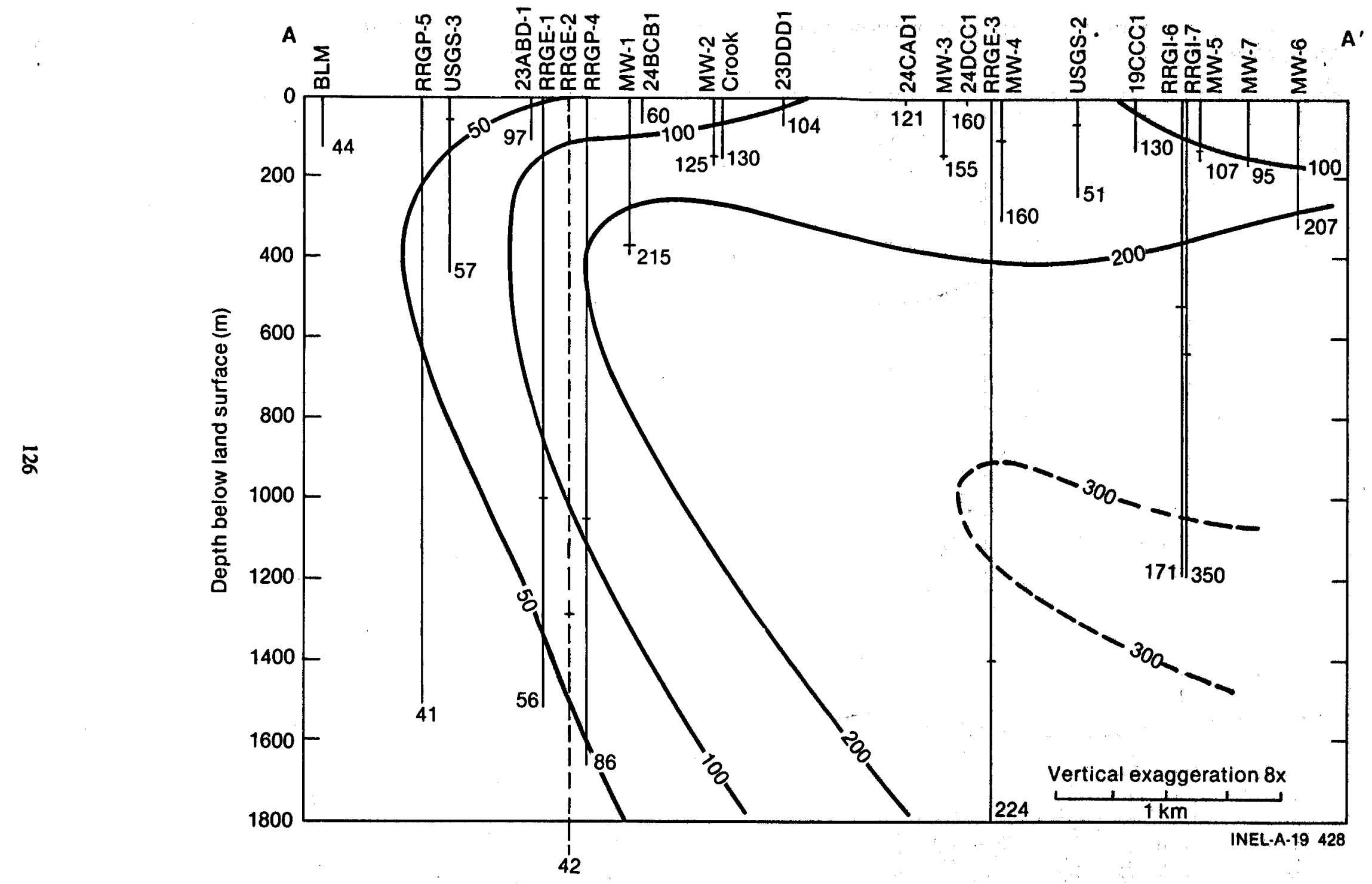

Figure 103. Cross section through the Raft River KGRA showing distribution of calcium in ground water. 


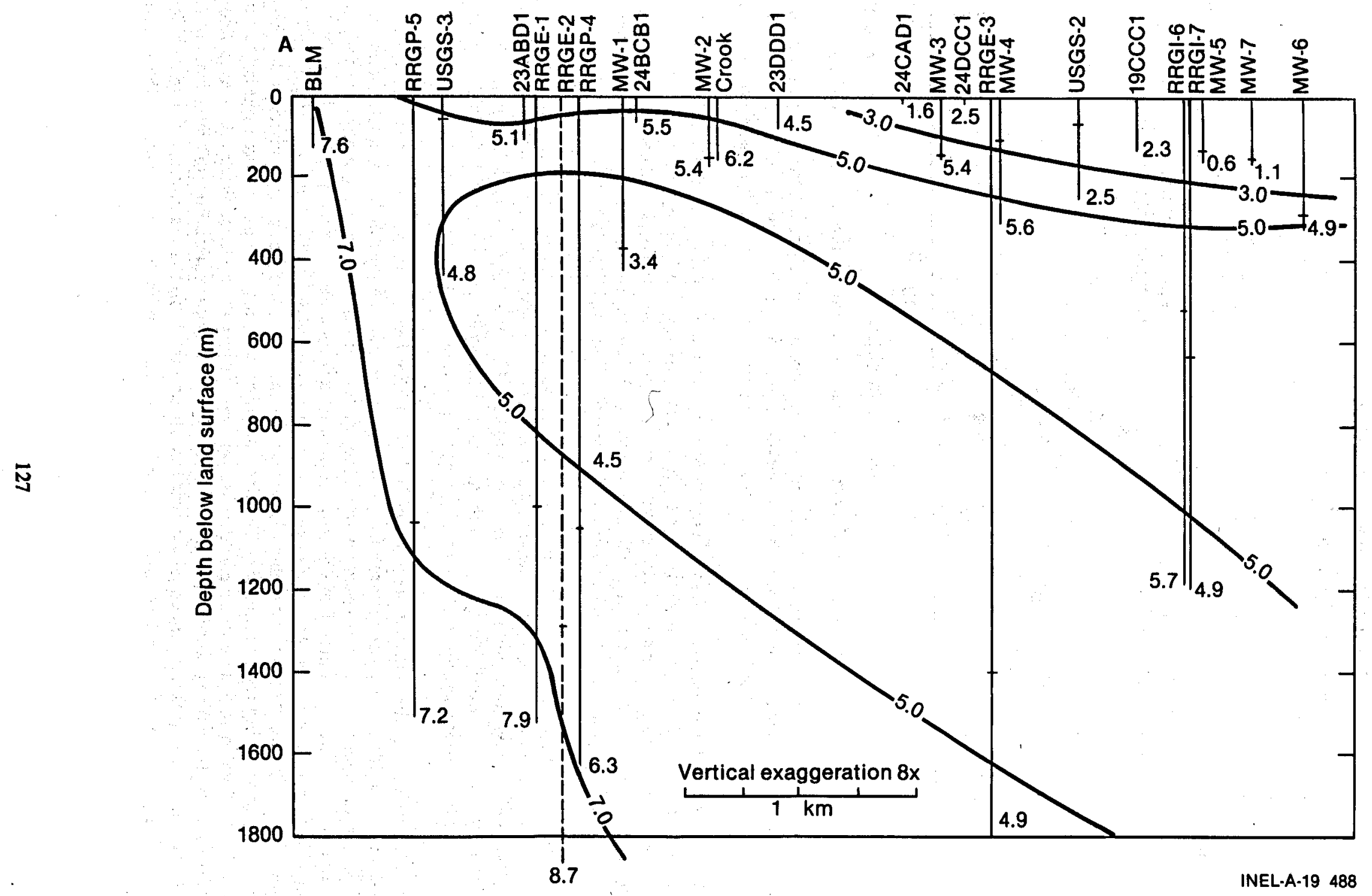

Figure 104. Cross section through the Raft River KGRA showing distribution of fluoride in ground water. 


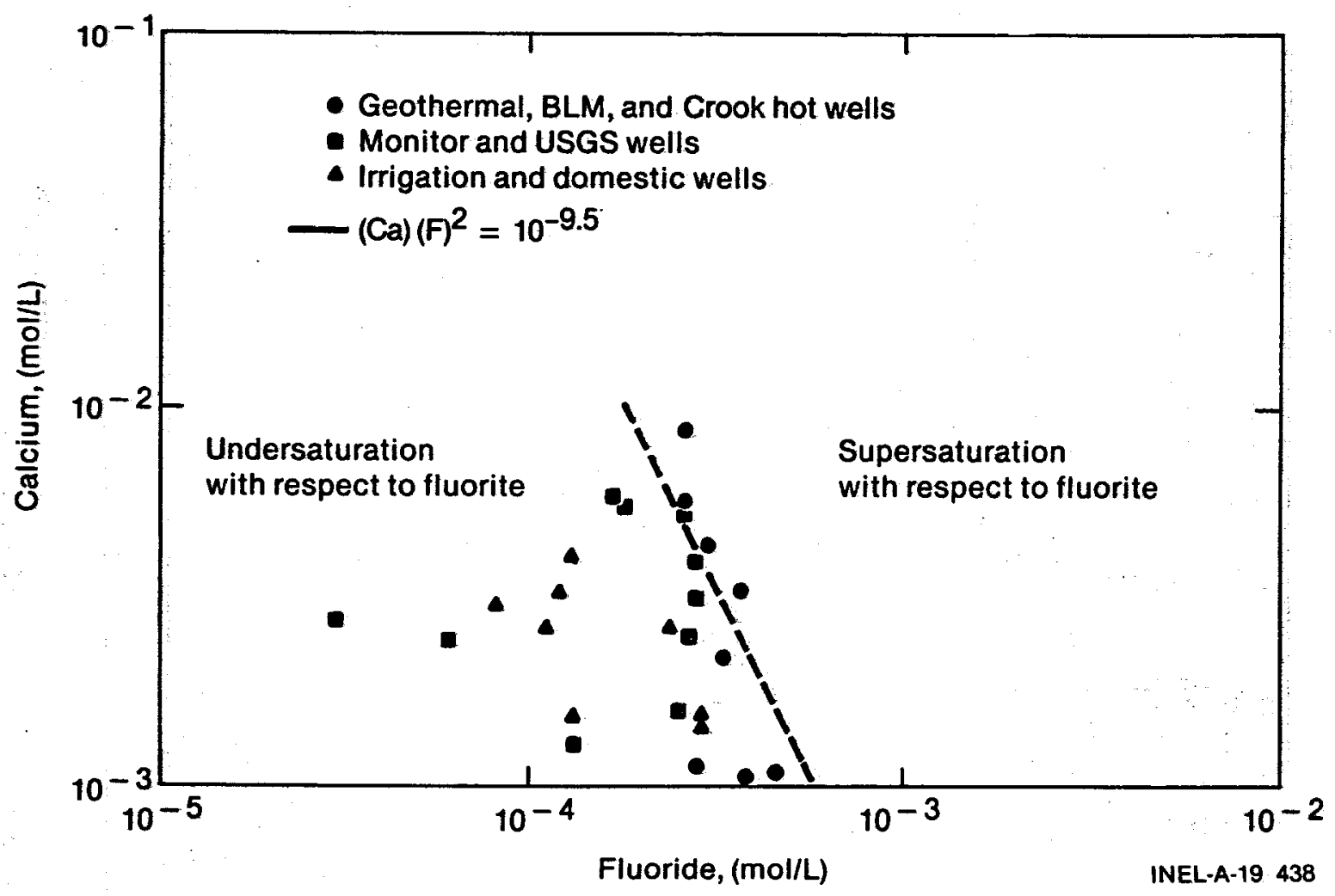

Figure 105. Plot of calcium and fluoride concentrations showing relation to fluoride saturation.

activities due to ionic strength variations, this dashed line does not exactly represent expected saturation with respect to fluorite for all samples. It does, however, give the approximate upper boundary of the data, and suggests that fluorite solubility does control fluoride concentrations in the deep geothermal waters.

5.2.3 Conceptual Model. The chemical composition of ground water is related to the hydrology of the ground-water system. Waters from different source areas, variations in lithology along flow paths, and variations in temperature history in geothermal reservoirs, produce differences in chemical composition. By using the chemistry as a tracer for waters, the sources and flow paths may be discernible. A conceptual model of the flow system at the KGRA has been developed from such information.

The cross sections suggest that cooler, high conductance water moves in from the southeast at a depth of between 1200 and $1600 \mathrm{~m}$. This water is warmed as it passes over a heat source between wells RRGE-3 and RRGP-4, and rises by convection to the surface around the Crook well. Water with low dissolved solids moves in from the northwest, is heated at depth, and rises in the vicinity of the BLM well. This suggests the presence of two different sources of water with very different chemical compositions.

An alternative hypothesis is that the water with the high dissolved solids is derived from the water with low dissolved solids either by concentration due to boiling in the reservoir, or by extensive alteration of rock material. Figure 106 shows oxygen and hydrogen isotopic compositions of ground water, both thermal waters and meteoric waters from nearby springs. Steam separation would produce large shifts in isotopic composition between waters of different concentrations of dissolved solids. The graph shows no trends that would support extensive boiling. Insufficient work has been done so far to discount the derivation of salts by altering the rock matrix. One line of evidence against this having occurred is the small isotopic shift, which indicates relatively little isotope exchange with rock materials. A second line of evidence against the concentration by boiling or leaching is that both require flow of water from a deep $(1800 \mathrm{~m})$ zone in the northwest, diagonally upwards to shallower depths to the southeast. Current geologic evidence suggests that structural controls on fluid movements probably are oriented in the opposite direction. 


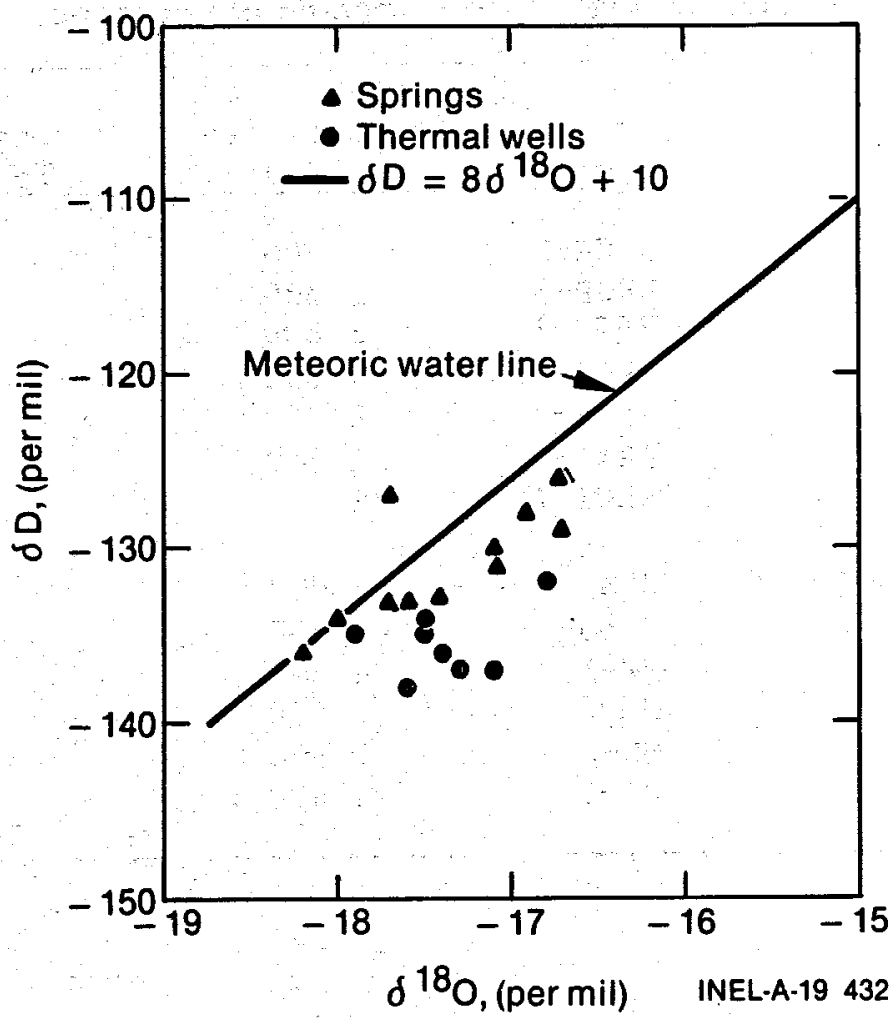

Figure 106. Plot of oxygen and hydrogen isotopic composition of ground waters showing relationship to meteoric water line.

With two waters having different chemistries, variation in the chemistry of intermediate waters can be due to mixing. This hypothesis was tested ${ }^{76}$ for the Raft River KGRA. The water from the northwest with low dissolved solids was labeled the Bridge-Fault water (type 1), and the water from the southeast with the high dissolved solids was labeled the central-valley water (type 2).

Mixing fractions are based on conductivity and calculated using equations

$\mathrm{X}_{1} \mathrm{C}_{1}+\left(1-\mathrm{X}_{1}\right) \mathrm{C}_{2}=\mathrm{C}_{\mathrm{m}}$

or

$x_{1}=\frac{C_{m}-C_{2}}{C_{1}-C_{2}}$

where $X_{1}$ is the fraction of Bridge-Fault water (type 1), $C_{1}$ is the conductivity of Bridge-Fault water, $C_{2}$ is the conductivity of central-valley water (type 2 ), and $C_{m}$ is the conductivity of mixed water. For the purpose of this calculation, it is assumed that the lowest conductivity water (from RRGE-2) represents nearly pure Bridge-Fault water $\left(C_{1}\right)$ and the highest conductivity water from RRGI-7 represents nearly pure central-valley water $\left(C_{2}\right)$. It is recognized that these two waters may not represent the actual end-member waters that are mixing. This assumption will not invalidate the calculations for the purpose of mixing for intermediate waters. Table 33 shows the mixing fractions calculated by Equation (4). Mixing fractions for both deep and intermediate depth wells are included.

To test the mixing hypothesis, the concentration of chloride in intermediate wells was calculated and compared to measured values. The results, illustrated in Figure 107, show generally good agreement between calculated and predicted values. 
Table 33. Mixing fractions calculated from specific conductance

\begin{tabular}{|c|c|c|c|}
\hline & We11 & $\begin{array}{l}\text { Conductivity } \\
\text { ( } \mu \text { mhos })\end{array}$ & $\begin{array}{l}\text { Mixing Fraction of } \\
\text { Type } 1 \text { Water } \\
\end{array}$ \\
\hline \multirow[t]{3}{*}{ Deep } & $\begin{array}{l}\text { RRGE-2 } \\
\text { RRGP-5 } \\
\text { RRGE-1 }\end{array}$ & $\begin{array}{ll}2 & 500 \\
2 & 700 \\
2 & 800\end{array}$ & $\begin{array}{l}1.000 \\
0.979 \\
0.968\end{array}$ \\
\hline & $\begin{array}{l}\text { RRGP-4 } \\
\text { RRGE-3 }\end{array}$ & $\begin{array}{ll}4 & 050 \\
8 & 000\end{array}$ & $\begin{array}{l}0.837 \\
0.421\end{array}$ \\
\hline & $\begin{array}{l}\text { RRGI-6 } \\
\text { RRGI-7 }\end{array}$ & $\begin{array}{ll}10 & 800 \\
12 & 000\end{array}$ & $\begin{array}{l}0.126 \\
0.000\end{array}$ \\
\hline \multirow[t]{2}{*}{ Intermediate Depth } & $\begin{array}{l}\text { BLM } \\
\text { Crook } \\
\text { MW-2 } \\
\text { MW-6 }\end{array}$ & $\begin{array}{ll}3 & 000 \\
5 & 800 \\
4 & 400 \\
7 & 600\end{array}$ & $\begin{array}{l}0.947 \\
0.653 \\
0.800 \\
0.463\end{array}$ \\
\hline & $\begin{array}{l}M W-4 \\
M W-1\end{array}$ & $\begin{aligned} 7800 \\
11400\end{aligned}$ & $\begin{array}{l}0.442 \\
0.063\end{array}$ \\
\hline
\end{tabular}

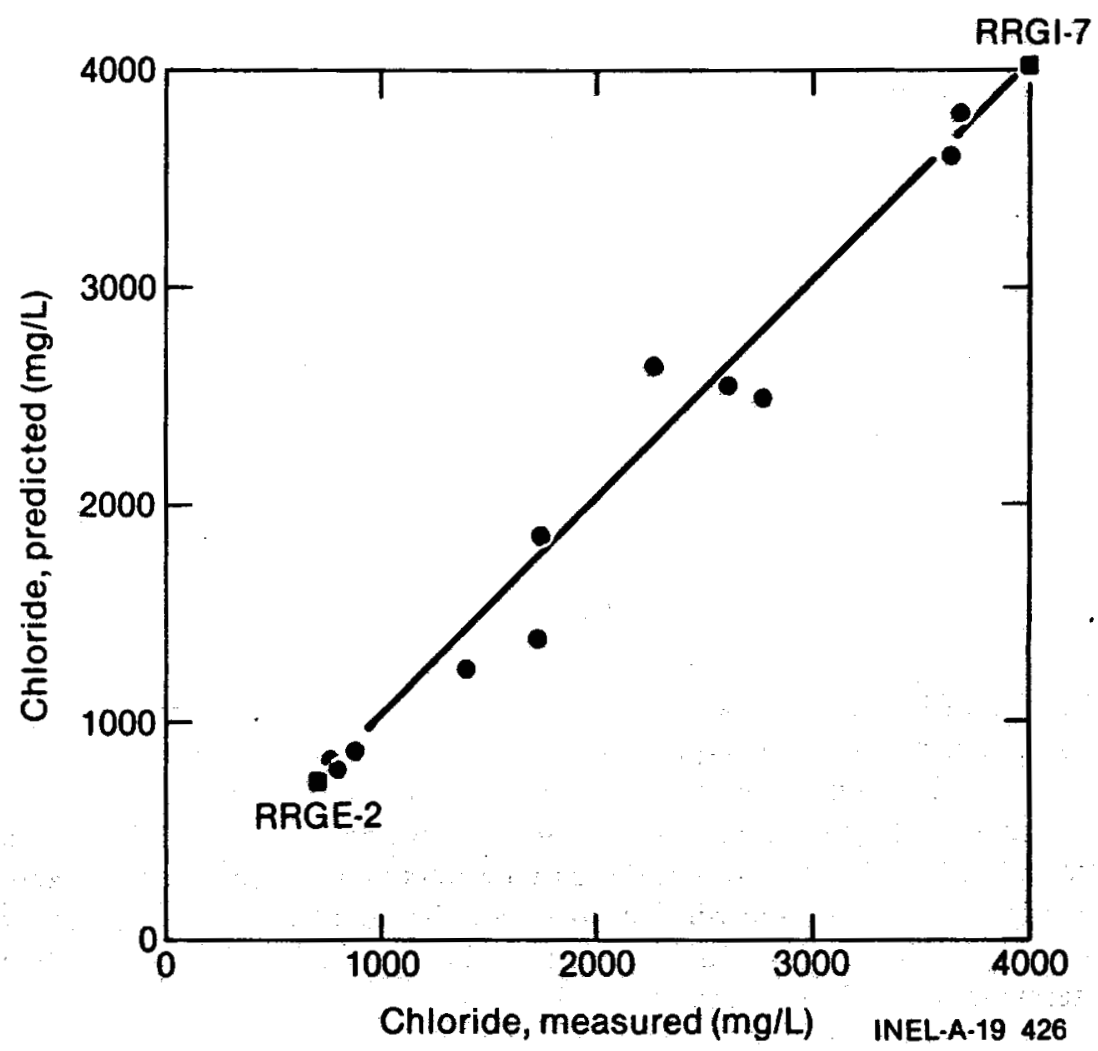

Figure 107. Comparison of measured and calculated chloride concentrations based on mixing model. 
Trilinear diagrams provide another convenient method for depicting the relationship between water samples. Trilinear diagrams show the percentage of cationic and anionic compositions of water samples in terms of meq/L. ${ }^{77}$ Figures 108 and 109 show partial trilinear diagrams for cations and anions for ground waters in the vicinity of the Raft River KGRA. Because of ion-exchange reactions, which primarily affect cations, the anion trilinear diagram shows the relationship among water samples much more clearly. Irrigation wells and some of the monitor wells plot along a line crossing the diagram between 3 and $6 \%$ sulfate (Figure 108). There is a second linear trend between RRGE-2 and RRGI-6 and -7 that depicts mixing in the geothermal reservoir. The linear trend of the wells across the diagram and the clustering of shallow-monitor and deep-geothermal wells in the same area emphasizes the intrusion of the geothermal waters into the shallow waters.

Figure 110 is a block diagram depicting the movement of water in the Raft River KGRA based on geochemical and geologic evidence. The source of heat for the KGRA is in or below the quartz monzonite in Sections 23, 24, 25 and 26 of township 15S, range 26E. There seems to be relatively little water associated with the heat source. Convection above this heat source draws water into the KGRA. Water from the southeast is high in dissolved solids, water from the northwest is low in dissolved solids. Movement is upwards along fracture zones dipping to the southeast associated with the Bridge Fault and Narrows structure. The origin of the water with low dissolved solids appears to be from meteoric water based on isotopic composition data. The origin of the water with high dissolved solids is still unknown.

In summary, geothermal fluids in the Raft River KGRA are derived from two sources of water. Meteoric water from the northwest descends along the valley margin, is heated at depths on the order of $2,000 \mathrm{~m}$ below land surface, then moves upwards along the Bridge Fault to the surface. Water from the centralvalley area, which is high in dissolved solids, is drawn into the KGRA by convection above the heat source. This water reaches the surface in the northwest corner of Section 25 , township $15 \mathrm{~N}$, range $26 \mathrm{E}$. The chemical variation in the geothermal wells can be explained by mixing of these two waters. Shallow ground waters also show chemical evidence of mixing of meteoric waters with the higher dissolved solids geothermal waters.

Based on the conceptual model of the Raft River KGRA, the location of the two existing injection wells, RRGI-6 and -7, is very good for protecting the geothermal resource. However, their location may not be as good in terms of limiting the environmental impact of injection. The injection zone is in the plume where water with high dissolved solids moves northwest from the valley center. Increased pressures from injection will increase the rate at which waters in the plume enter the shallow ground water. With more geothermal fluids rising in this area, dilution by shallow waters will decrease, and the dissolved solids in the shallow waters will increase. The limited area currently affected by the rising plume suggests that upward migration from the southeast is relatively small.

\subsection{Injection Studies}

Because of environmental concerns associated with surface disposal of geothermal waters, subsurface injection of the cooled fluid from the SMW(e) plant is planned at the Raft River KGRA. Two studies were carried out to evaluate potential problems of aquifer clogging during injection. The first test involved the evaluation of water compatibility, that is, the effects of mixing geothermal waters from two or more wells on the quantity of chemical precipitates formed. This test showed the potential for clogging receiving zones in injection wells due to chemical reactions. In a second test, the quantity and size distribution of suspended particulate matter was measured. This test gave the potential for clogging due to physically transported material, and indicated filter sizes needed to remove particulate matter. Both tests are discussed below.

5.3.1 Water Compatibility Test. The water compatibility test is an empirical determination of the synergistic effects of mixing water from two or more wells. The results indicate the changes in suspended solids in the mixtures due to chemical reactions between the waters. Increases in suspended solids from precipitation reactions is an important criteria which limits the feasibility of injection. Injection of excessive particulate matter, or the formation of chemical precipitates in an aquifer can cause serious plugging problems in injection wells. 


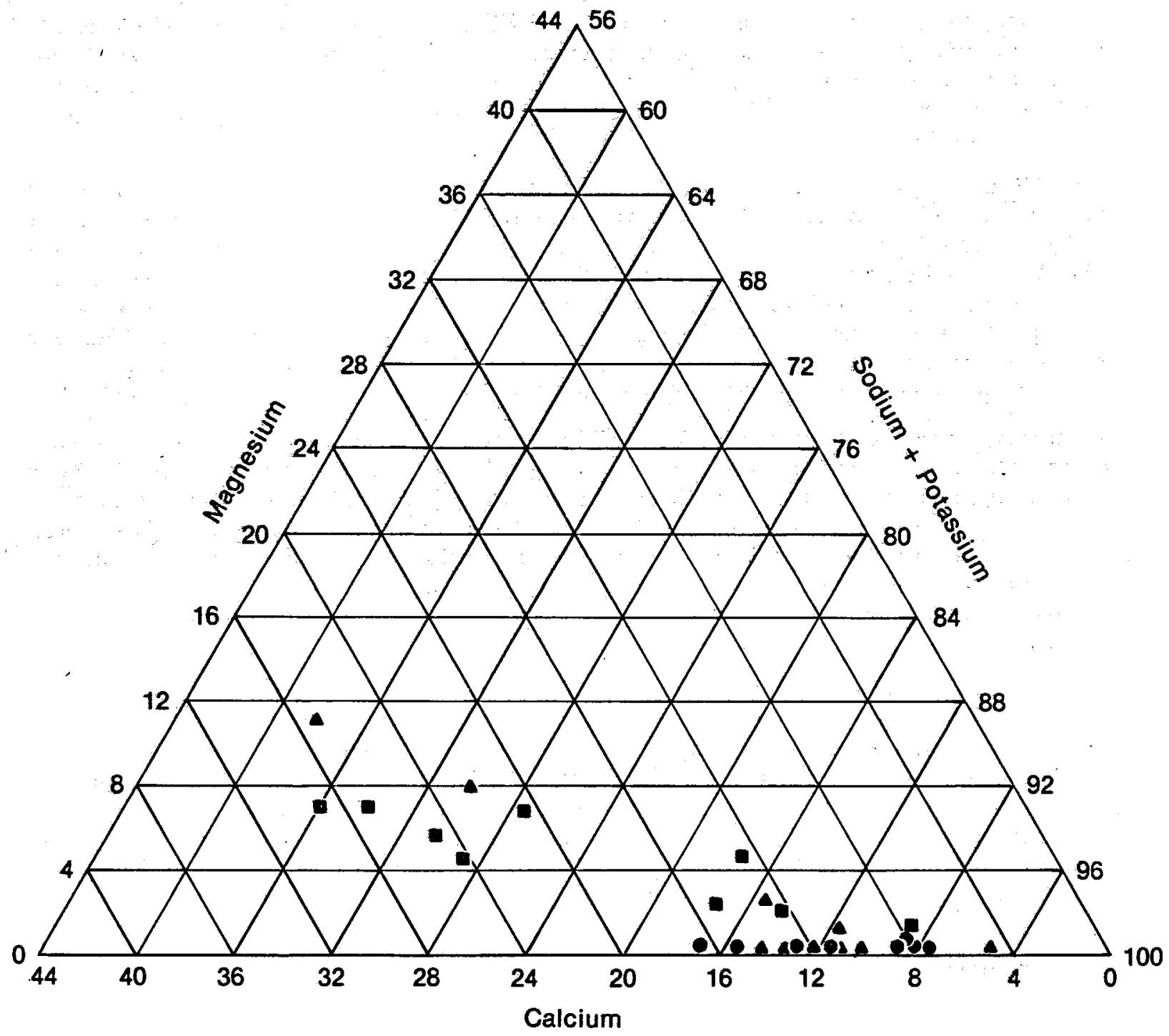

- Geothermal, BLM, and Crook hot wells

- Monitor and USGS wells

- Irrigation and domestic wells

INEL-A-19 439

Figure 108. Sodium and potassium corner of cation, trilinear diagram showing percentage of cationic compositions of ground water. 


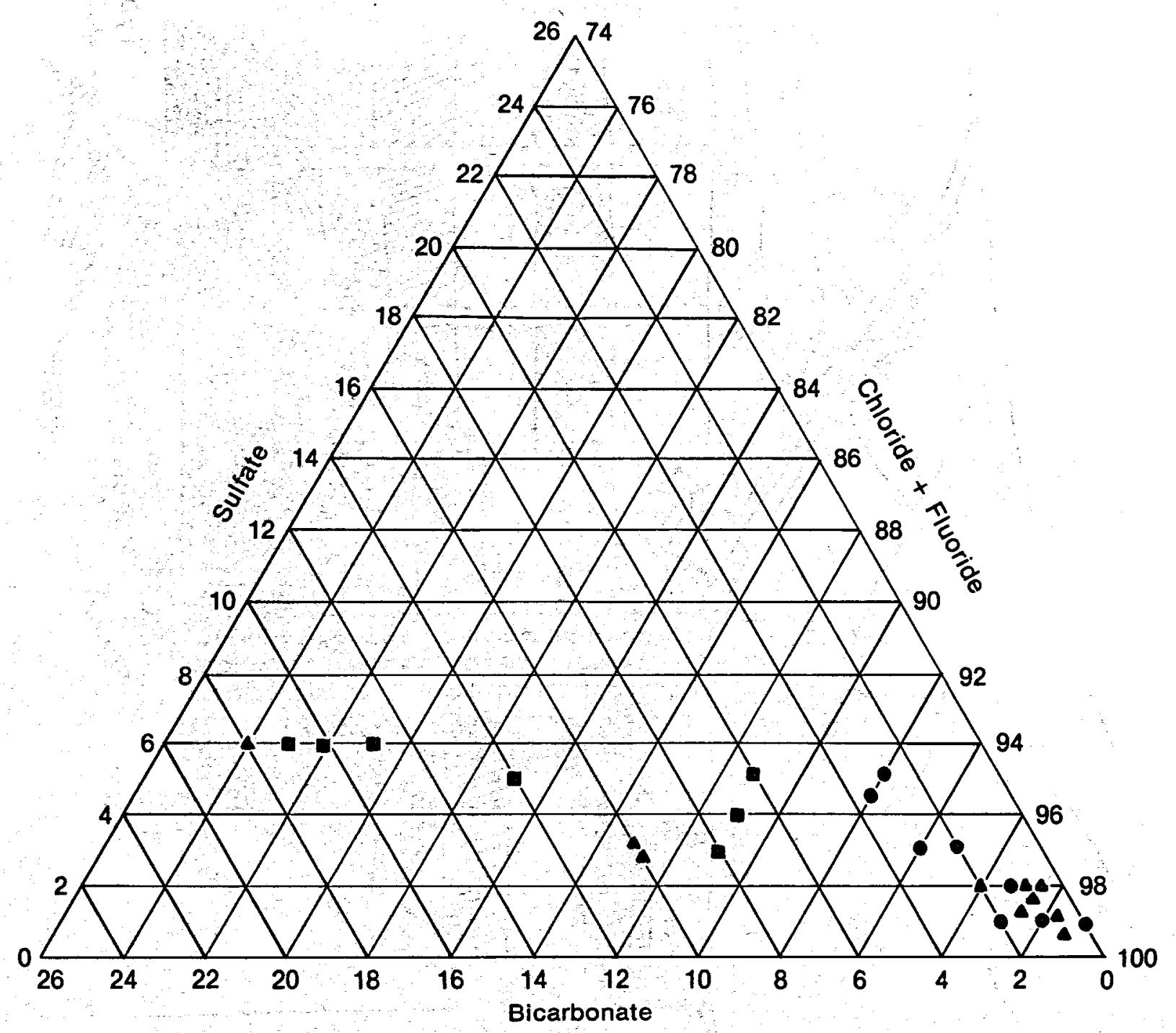

- Geothermal, BLM, and Crook hot wells

- Monitor and USGS wells

- Irrigation and domestic wells

INEL-A-19 430

Figure 109. Chloride and fluoride corner of anion trilinear diagram showing percentage of anionic compositions of ground waters. 


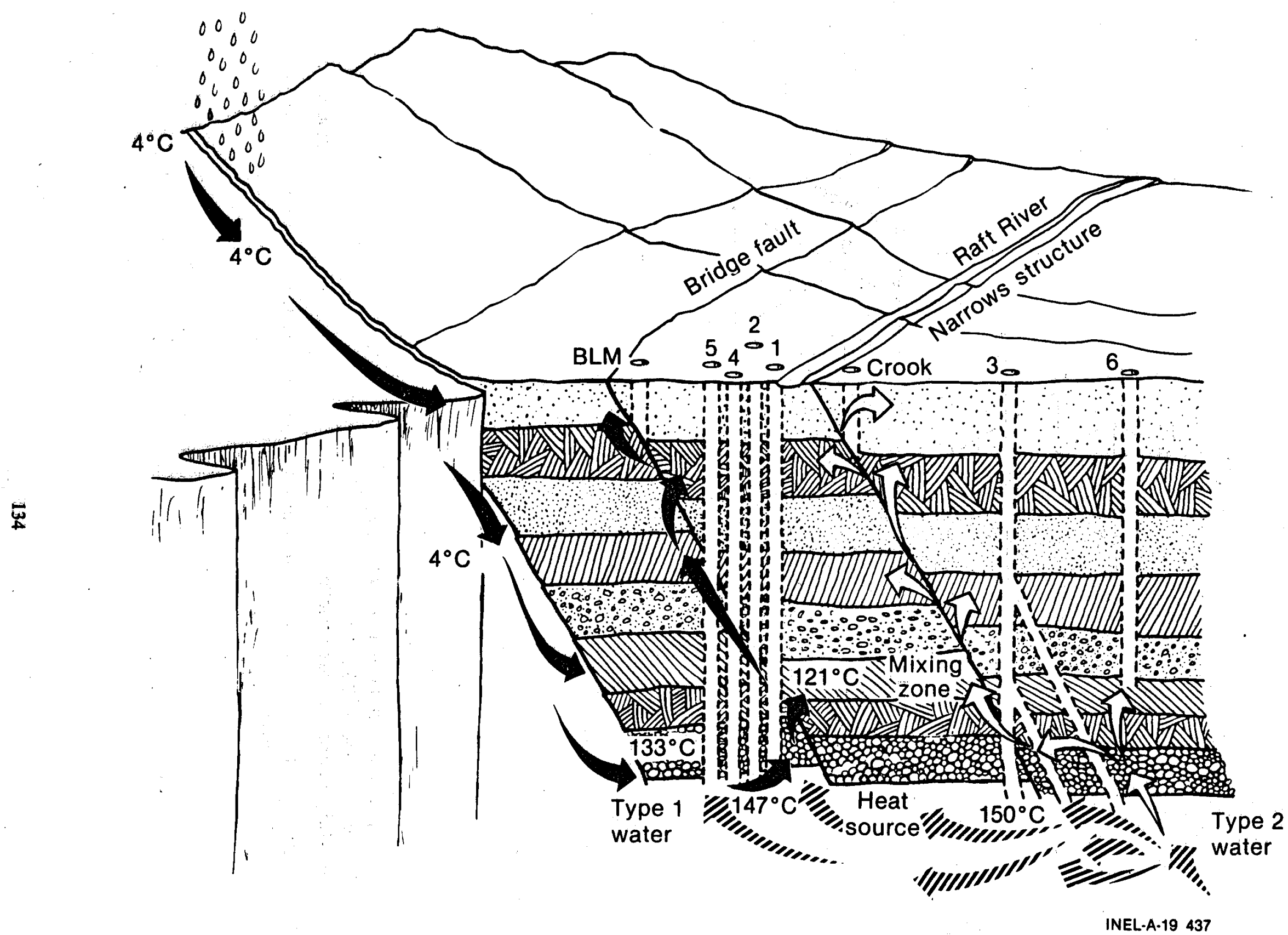

Figure 110. Conceptual model of flow in the Raft River KGRA. 
5.3.1.1 Experimental Procedure-Experiments were carried out at two temperatures to simulate two possible injection schemes. One set of experiments was carried out at $20^{\circ} \mathrm{C}$, the temperature expected for injection of water from holding ponds; the second set was carried out at $70^{\circ} \mathrm{C}$ to simulate injection of water directly from the $5 \mathrm{MW}(\mathrm{e})$ facility. Water samples were collected from RRGE-1, -2, -3, RRGP-5, and RRGI-6, and filtered through $0.45 \mu$ membrane filters to remove any suspended solids. Mixtures were prepared by mixing all possible permutations of water combinations. The final volume of $1 \mathrm{~L}$ was made up of equal portions of each water in the mixture. Control samples of unmixed water from each well were also included. Samples could not be collected from RRGP-4 and RRGI-7, so they were not included in the analysis.

After 24 hours at $20^{\circ} \mathrm{C}$ or $70^{\circ} \mathrm{C}$, the mixtures were filtered through tared $0.45 \mu$ filters and filters dried at $95^{\circ} \mathrm{C}$ for one hour. Residue and filter were then weighed on an analytical balance and the residue calculated by difference.

5.3.1.2 Resu/ts-The quantity of precipitate expected in the mixed samples, assuming no synergistic effects, was calculated by summing the products of the solids formed in the control samples multiplied by the fraction of the sample in the mixture. If there are no synergistic effects of mixing, the measured and calculated amounts of precipitate should be equal.

Results of the measurements and calculations are shown in Table 34. The columns headed "actual" show the weights of precipitated solids determined from filtering the weighing. The columns headed "calculated" show the predicted quantity of precipitate assuming no interactive effects in the mixtures.

To determine if there is a significant effect on the quantity of precipitated solids due to mixing, differences between calculated and actual weights of solids were calculated. If there are no synergistic effects, the mean of the differences should equal zero. A significant positive or negative difference would indicate an enhancement or inhibition of solids formation, respectively. For the 25 mixtures held at $20^{\circ} \mathrm{C}$, the average difference is $-0.44 \mathrm{mg} / \mathrm{L}$ with a $95 \%$ confidence interval from -0.78 to $-0.10 \mathrm{mg} / \mathrm{L}$. For the $25 \mathrm{mix}-$ tures held at $70^{\circ} \mathrm{C}$, the average difference is $-0.37 \mathrm{mg} / \mathrm{L}$ with a $95 \%$ confidence interval from -0.53 to $-0.21 \mathrm{mg} / \mathrm{L}$. There is a significant inhibition effect due to mixing, with mixed waters producing an average of about $0.4 \mathrm{mg} / \mathrm{L}$ less precipitated solids than expected from the amount of solids precipitated from the unmixed waters.

To assess the effects of temperature on the quantity of precipitate formed, the average amount of filtered solids for the mixed samples at the two temperatures was compared. For the mixtures held at $20^{\circ} \mathrm{C}$, the average was $1.25 \mathrm{mg} / \mathrm{L}$ with a standard error of $0.19 \mathrm{mg} / \mathrm{L}$. For the samples held at $70^{\circ} \mathrm{C}$, the average amount of precipitate formed was $0.19 \mathrm{mg} / \mathrm{L}$ with a standard error of $0.08 \mathrm{mg} / \mathrm{L}$. The amount of solids formed in mixtures held at $20^{\circ} \mathrm{C}$ was significantly greater than that for samples held at $70^{\circ} \mathrm{C}$.

Examination of the amounts of solids precipitated from the unmixed samples shows that RRGE-1, -2 and RRGP-5 produce relatively little precipitate. Wells RRGE-3 and RRGI-6 produce from two to three times as many solids as the other wells. Hot waters injected into RRGI-6 directly from the 5MW(e) plant can be expected to form about $0.2 \mathrm{mg} / \mathrm{L}$ of solids on the average.

In summary, therefore, mixing of water from wells RRGE-1, -2, -3, RRGP-5, and RRGE-6 shows no incompatibility. In fact, water mixtures show less formation of precipitated solids than that anticipated from quantities formed from unmixed waters. There is a significant inhibition effect, with about $0.4 \mathrm{mg} / \mathrm{L}$ fewer solids formed than estimated. Samples held at $70^{\circ} \mathrm{C}$ showed significantly less precipitate formation than those held at $20^{\circ} \mathrm{C}$. Injecting water that directly leaves the power plant would minimize the formation of suspended solids. Even with only $0.2 \mathrm{mg} / \mathrm{L}$ of chemical precipitate formed, $2.2 \mathrm{~kg} /$ day of solids would be injected into the aquifer assuming an average flow of $126 \mathrm{~L} / \mathrm{s}$.

5.3.2 Filter Studies. Studies were carried out to evaluate the amount and particle size distribution of suspended solids in the geothermal waters. Injection of excessive suspended solids can cause injection wells to clog ruining their utility. An analysis of the size distribution of suspended solids would permit the sizing of filter screens for the injection system. Particle size distributions were determined for water from RRGE-2 and -3. Total solids were monitored during two additional tests. 
Table 34. Water compatibility for geothermal wells RRGE-1, RRGE-2, RRGE-3, RRGP-5 and RRGI-6

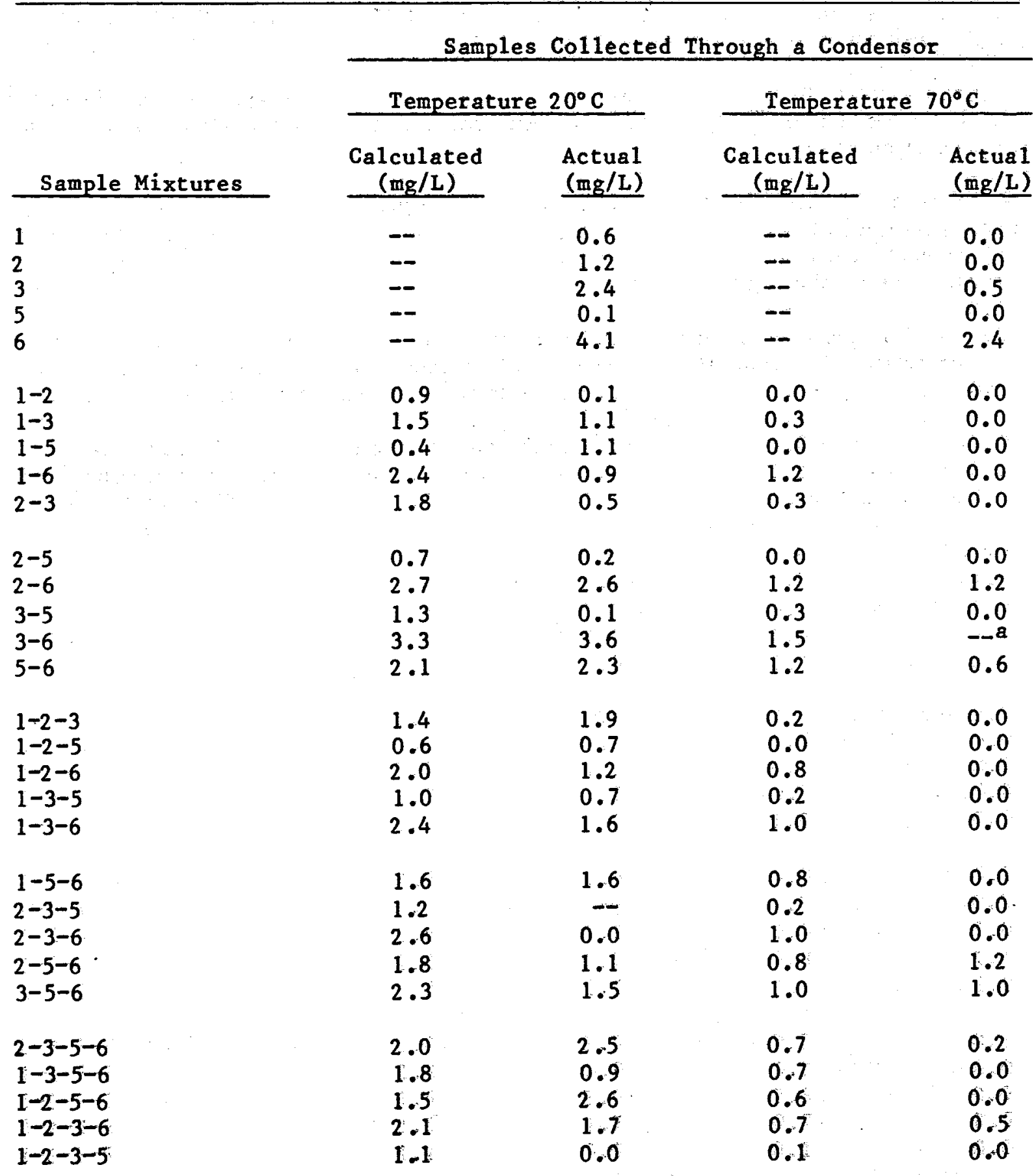




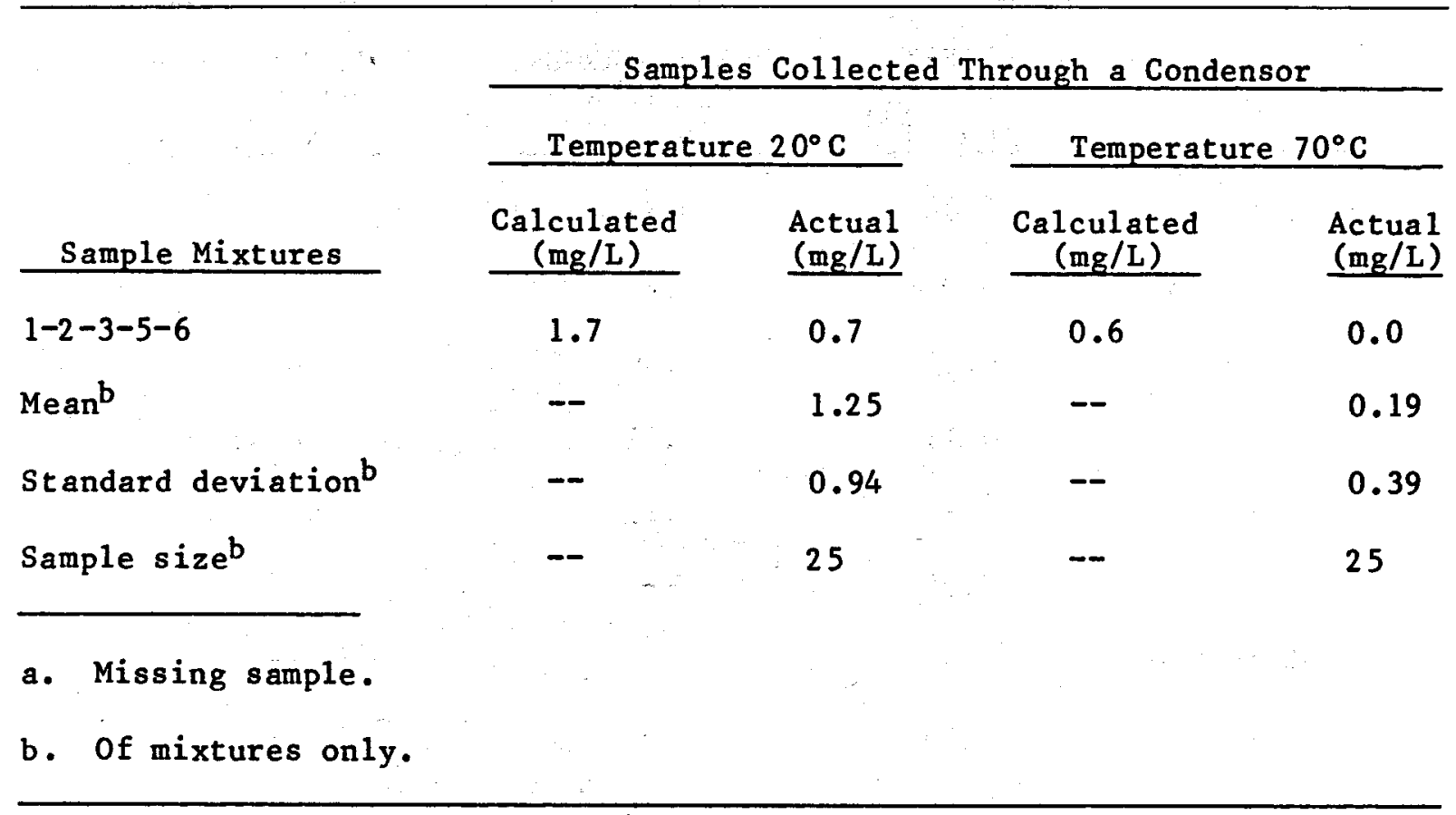

5.3.2.1 Experimental Procedure-The filtering apparatus used in the tests consisted of a series of stainless steel filters in the following sizes and order: $230,140,90,60,15$, and $2 \mu . A 0.45 \mu$ membrane filter was also used. The 230 and $140 \mu$ filters were used in only one test. For determining total suspended solids, the $2.0 \mu$ filter was used alone. The filters were placed in stainless steel filter holders, and from 20 to $100 \mathrm{~L}$ of water passed through the series. Filters were dried at $105^{\circ} \mathrm{C}$ for three hours and weighed on an analytical balance. The quantity of suspended solids was determined by subtracting the tared weight of the filter.

5.3.2.2 Resu/ts-Table 35 shows the weights of suspended solids collected on filters of various pore sizes from wells RRGE-2 and -3. The third column shows the amount of solids in water collected from RRGE-3 just before injection into RRGI-4, after it had passed through the pipeline system connecting the two wells. The quantity of suspended solids from RRGE-3 is much higher than that from RRGE-2. A major source of suspended material is from the distribution system itself. The distribution of particle sizes shows that almost all of the particles from the wells are less than $90 \mu$ in diameter. More particulate matter was picked up in the distribution system than from the wells. This material was generally larger than $90 \mu$.

To test for temporal effects, RRGE-2 was tested for total suspended solids every 24 hours for five days during an injection test of RRGI-6. There was a general increasing trend in solids from $0.17 \mathrm{mg} / \mathrm{L}$ the first day to just over $1 \mathrm{mg} / \mathrm{L}$ on the fifth day. Concentrations were in the same range as for the earlier test on RRGE-2. Five days, however, was not sufficient time for the solids to stabilize, and the long term concentration of suspended solids cannot be predicted from this data.

Suspended solids were determined during a fourth injection test, when water from the holding pond at RRGE-1 was injected into RRGI-7. The average concentration of suspended solids in this water was $34.8 \mathrm{mg} / \mathrm{L}$, much higher than that produced from either RRGE-2 or -3 .

In summary, therefore, knowing the particle size of the undissolved solids in injection water is important in determining filter size, designing filtering systems, and determining the impact on the production zones in an injection well. The studies of particle size conducted on the injection of water from RRGE-2 into RRGP -4 , and the injection of water from RRGE-3 into RRGP-4 indicated that $\simeq 80 \%$ of the undissolved solids were smaller than $90 \mu$. 
Table 35. Particle size distributions of suspended solids in geothermal waters

\begin{tabular}{|c|c|c|c|}
\hline $\begin{array}{c}\text { Particle Size } \\
\text { Range } \\
\text { (m) }\end{array}$ & $\begin{array}{c}\text { RRGE-2 } \\
05 / 18 / 78 \\
(\mathrm{mg} / \mathrm{L}) \\
\end{array}$ & $\begin{array}{c}\text { RRGE-3 @ RRGE-3 } \\
03 / 21 / 78 \\
(\mathrm{mg} / \mathrm{L}) \\
\end{array}$ & $\begin{array}{c}\text { RRGE-3 @ RRGI-4 } \\
03 / 22 / 78 \\
(\mathrm{mg} / \mathrm{L}) \\
\end{array}$ \\
\hline 0.45 to 2 & 0.08 & 0.87 & 1.49 \\
\hline 2 to 15 & 0.09 & 2.12 & 8.12 \\
\hline 15 to 60 & 0.10 & 0.56 & 6.54 \\
\hline 60 to 90 & 0.11 & 0.51 & 6.41 \\
\hline$>90$ & - & 0.72 & 51.6 \\
\hline 90 to 140 & 0.04 & - & -- \\
\hline 140 to 230 & 0.00 & - & -- \\
\hline$>230$ & 0.06 & -- & - \\
\hline Total & 0.48 & 4.78 & 74.16 \\
\hline
\end{tabular}

Also in RRGE-3, 35.5\% of the undissolved solids were between 2.0 and $15.0 \mu$. This would require very small filters to remove the major portion of the undissolved solids. Large amounts of suspended solids are picked up in the pipeline carrying water to the injection well. About $94 \%$ of the solids measured at the wellhead of RRGI-4 were from this source. Without removal of these suspended solids, $800 \mathrm{~kg}$ of solids per day could be injected into the ground. Even with installation of $90 \mu$ filters, however, $245 \mathrm{~kg}$ of solids per day would be injected assuming the operating flow of the plant at $126 \mathrm{~L} / \mathrm{s}$. This is a rather large quantity of solids, and could significantly interfere with injection of the spent fluids.

The filter study of the water from RRGE-2 that was injected into RRGI-6 indicated a trend of increasing amounts of undissolved solids as the test progressed. Unfortunately, the test was terminated before it could be determined if the increase in solids was the result of the wellbore being flushed of residual materials.

Suspended solids increased significantly during transit through pipelines connecting the production and injection wells. Water injected from the pond was intermediate in suspended solids. Some or most of this material is probably due to intermittent operation of the plant, and may be decreased by flushing of pipelines.

\subsection{Conclusions}

The geochemical studies at the Raft River KGRA reveal several areas of concern for the injection of spent geothermal fluids. While there should be no problem of the cooled, injected fluids interfering with the geothermal resource, injection over long periods of time could increase the area of shallow ground water affected by geothermal fluids. Higher pressures at depth in the injection zone will gradually increase the rate at which water, having high dissolved solids, moves upward into the shallow aquifer. This movement could probably occur very slowly, and require many years for any effects to be noted. 
The formation of chemical precipitates in mixtures of waters from the various geothermal wells is not a major concern. Suspended solids are also low in fluids pumped from wells. However, there is a large increase in suspended solids as fluids move through the pipeline connecting production wells with injection wells. Whether this is a result of the irregular operation of the plant during early testing, or will be a permanent problem was not evaluated. Injection of water from a holding pond produced a value for suspended solids intermediate between the high value measured in the distribution system, and the low values measured at the production wells. Values of suspended solids measured at the injection well were enough to give concern about plugging of injection zones. 


\section{CONCLUSION}

Although the Raft River geoscience work still needs further research, a number of conclusions can be made. The work clearly shows that the resource is produced from fractures found at the contact metamorphic zone, near the intersection of the Narrows Zone and the Bridge Fault Zone. From these two major structures, and possibly fractures in the Salt Lake Formation, upward leakage and lateral spreading of hydrothermal fluids allows for anomalous productive hot zones in shallow hot wells (i.e., Crook and BLM wells).

Commercial borehole geophysical logging of the Raft River wells confirms the fact that the Salt Lake Formation sediments, in general, are not very permeable and porous and that fluids are produced from anomalous zones. Because of rock alterations, fracturing, and numerous borehole washouts, the commercial geophysical logs need to be investigated in greater detail to obtain a thorough survey. The program was not funded to allow this. The logs clearly show formation tops among the various rock types.

Well testing at Raft River reveals that the geothermal reservoir is anisotropic, with the major axis of hydraulic conductivity coincident to the Bridge Fault Zone. The production zone and hydrogeologic environment is extremely complex, but is typical of many Basin and Range systems. Further analysis of the production data of this reservoir during plant operation can provide greater insight into this complex reservoir.

While cooled, injected fluids will not interfere with the geothermal resource, their injection over long periods of time could increase the area of shallow ground water affected by geothermal fluids. Because of the higher pressures at depth in the injection zone, the rate at which water above the injection zone moves upward may be increased. This movement may drive the lower quality water in this zone upward into the shallow aquifers. However, movement would be very slow and would require years of injection for any effects to be noted. 


\section{REFERENCES}

1. J. F. Kunze et al., A Low Temperature Demonstration Geothermal Power Plant in the Raft River Valley, ANCR-1138, April 1974.

2. P. L. Williams et al., "Geology and Geophysics of the Southern Raft River Valley Geothermal Area, Idaho, USA,"' Proceedings of the Second U.N. Symposium on the Development and Use of Geothermal Resources, 1976, pp. 1273-82.

3. J. F. Kunze, Geothermal R\&D Project Report for Period April 1975 to June 30, 1975, ANCR-1247, September 1975.

4. Reynolds Electrical \& Engineering Co., Inc., Completion Report-Raft River Geothermal Exploratory Hole No. 1 (RRGE-1), ID0-10062, (NV0-410-30), October 1975.

5. J. L. Speake (compiler), Completion Report-Raft River Geothermal Exploratory Hole No. 2 (RRGE-2) , ID0-10066, NV0-410-34, August 1976.

6. H. H. Shoopman, Completion Report-Raft River Geothermal Exploratory Hole No. 3 (RRGE-3), ID0-10069 (NV0-410-40), June 1977.

7. S. G. Spencer, J. F. Sullivan, N. E. Stanley, 1978 Annual Report, INEL Geothermal Environmental Program, TREE-1340, April 1979.

8. W. L. Niemi and L. B. Nelson, "Injection Testing at RRGI-4, Raft River, Idaho," Proceedings of the Second Invitational Well Testing Symposium, Lawrence Berkeley Laboratory, October 24-27, 1978.

9. L. G. Miller and S. M. Prestwich, Completion Report-Raft River Geothermal Injection Well Six (RRGI-6), ID0-10083, February 1979.

10. L. G. Miller and S. M. Prestwich, Completion Report-Raft River Geothermal Production Well Four (RRGP-4), ID0-10081, February 1979.

11. D. E. French, Geology and Mineralization of the Southeastern Part of the Black Pine Mountains, Cassia County, Idaho, M.S. Thesis, Utah State University, 1975.

12. P. L. Williams et al., Preliminary Geologic Map of the Southern Raft River Area, Cassia County, Idaho, United States Geological Survey Open-File Report, 1974.

13. A. L. Anderson, "Geology and Mineral Resources of Eastern Cassia County, Idaho," Idaho Bureau of Mines and Geology Bulletin, 14, $1931 \mathrm{~b}$.

14. R. R. Compton, Geologic Map of the Park Valley Quadrangle, Box Elder County, Utah and Cassia County, Idaho, United States Geological Survey Miscellaneous Geologic Inventory Map I-873, 1975.

15. R. R. Compton et al., "Oliogocene and Miocene Metamorphism, Folding and Low-Angle Faulting in Northwest Utah," Geological Society of America Bulletin, 88, 1977, pp. 1237-1250.

16. H. R. Covington, Deep Drilling Data, Raft River Geothermal Area, Idaho-Raft River Geothermal Exploration Well No. 1, United States Geological Survey Open-File Report 77-226, 1977a.

17. H. R. Covington, Deep Drilling Data, Raft River Geothermal Area, Idaho-Raft River Geothermal Exploration Well No. 2, United States Geological Survey Open File Report 77-243, 1977b. 
18. H. R. Covington, Deep Drilling Data, Raft River Geothermal Area, Idaho-Raft River Geothermal Exploration Well No. 3, United States Geological Survey Open-File Report 77-616, 1977 c.

19. H. R. Covington, Deep Drilling Data, Raft River Geothermal Area, Idaho-Raft River Geothermal Exploration Well No. 3, Sidetrack C, United States Geological Survey Open-File Report 77-883, 1977d.

20. H. R. Covington, Deep Drilling Data, Raft River Geothermal Area, Idaho-Raft River Geothermal Exploration Well No. 4, United States Geological Survey Open-File Report 78-91, 1978.

21. H. R. Covington, Deep Drilling Data, Raft River Geothermal Area, Idaho-Raft River Geothermal Exploration Well No. 5, United States Geological Survey Open-File Report 79-382, 1979a.

22. H. R. Covington, Deep Drilling Data, Raft River Geothermal Area, Idaho-Raft River Geothermal Production Well No. 4, United States Geological Survey Open-File Report 79-662, $1979 \mathrm{~b}$.

23. H. R. Covington, Deep Drilling Data, Raft River Geothermal Area, Idaho-Raft River Geothermal Exploration Well No. 6, United States Geological Survey Open-File Report 79-1129, 1979c.

24. H. R. Covington, Deep Drilling Data, Raft River Geothermal Area, Idaho-Raft River Geothermal Exploration Well No. 7, United States Geological Survey Open-File Report 79-1365, 1979d.

25. S. C. Devine and B. Bonnichsen, Petrography of Drill Cores from the Raft River Geothermal Area, Southern Idaho, Unpublished Report to the Department of Energy, December 1979

26. K. S. Kennedy, Environment of Deposition of the Upper Three Hundred Meters of Sediments of the Raft River KGRA, EG\&G, PG-G-80-026, 1, 1980.

27. J. A. Saunders, Low Temperature Hydrothermal Alteration of the Raft River Geothermal Area, Idaho, Unpublished Report Presented to the Department of Energy and EG\&G, May 1980.

28. H. D. Ackerman, "Seismic Refraction Study of the Raft River Geothermal Area," Geophysics, 44, 2, February 1979, pp. 216-225.

29. H. R. Covington, "Subsurface Geology of the Raft River Geothermal Area, Idaho," Geothermal Resources Council Transactions, 4, September 1980.

30. R. R. Compton, Geologic Map of the Yost Quadrangle, Box Elder County, Utah and Cassia County, Idaho, United States Geological Survey Miscellaneous Geologic Inventory Map I-672, 1972.

31. D. R. Mabey, private communication, United States Geological Survey, Salt Lake City, May 1980.

32. H. D. Ackerman, Velocity Sections in Raft River, Idaho, Geothermal Area from Seismic Refractions, United States Geological Survey Open-File Report 78-105, 1975.

33. D. B. Hoover, Audio-Magnetotellurie Apparent Resistivity Maps, Southern Raft River Area, Cassia County, Idaho, United States Geological Survey Open-File Report, 1974.

34. D. R. Mabey, Bouguer Gravity Anomaly Map of the Southern Raft River Area, Cassia County, Idaho, United States Geological Survey Open-File Report, 1974a.

35. D. R. Mabey, Principal Facts for Gravity Stations in the Raft River Valley, Idaho, United States Geological Survey Open-File Report, 1973a, p. 5. 
36. D. R. Mabey and C. W. Wilson, Regional Gravity and Magnetic Surveys in the Albion Mountains Area of Southern Idaho, United States Geological Survey Open-File Report, 1973b, p. 12.

37. D. R. Mabey, D. L. Peterson, C.W. Wilson, Preliminary Gravity Map of Southern Idaho, United States Geological Survey Open-File Report 74-78, $1974 \mathrm{~b}$.

38. D. R. Mabey et al. Bouguer Gravity Anomaly Map of the Southern Raft River Area, Cassia County, Idaho, United States Geological Survey Open-File Report, 1973c.

39. United States Geological Survey, Residual Magnetic Intensity Map of the Raft River Area, Cassia County, Idaho, Open-File Report, 1974.

40. A. A. R. Zohdy, D. B. Jackson, R. J. Bisdorf, Schlumberger Soundings and Total Field Measurements in the Raft River Geothermal A rea, Idaho, United States Geological Survey Open-File Report 75-130, 1975.

41. A. A. R. Zohdy and R. J. Bisdorf, Schlumberger Soundings in the Upper Raft River and Raft River Valleys, Idaho and Utah, United Stätes Geological Survey Open-File Report 76-92. 1976.

42. D. R. Mabey et al. "Reconnaissance Geophysical Studies of the Geothermal System in Southern Raft River Valley, Idaho, Geophysics 43, 7, 1978, pp. 1470-1484.

43. Schlumberger, Log Interpretations Principles, Houston, Texas: Schlumberger Well Services, 1969, p. 105.

44. A. Poupon, W. R. Hoyle, A. W. Schmidt, "Log Analysis in Formulations with Complex Lithologies," Presented at the 45th Annual Fall Meeting of the Society of Petroleum Engineers, October 1970.

45. S. J. Pirson, "How to Map Fracture Development from Well Logs," World Oil, March 1967, pp. 106-114.

46. J. Beck, A. Schultz, D. Fitzgerald, "Reservoir Evaluation of Fractured Cretaceous Carbonates in South Texas," Transactions of the Society of Professional Well Log Analysts, 1977.

47. J. Zemanek et al., "The Borehole Televiewer: A New Logging Concept for Fracture Location and Other Types of Borehole Inspection,"' Journal of Petroleum Technology, June 1969, pp. 762-774.

48. M. S. Keyes and J. K. Sullivan, "The Role of Borehole Geophysics in Defining the Raft River Geothermal Reservoir,"' Geophysics, 44, 6, 1979, pp. 111-1141.

49. R. C. Stoker, D. Goldman, J. F. Kunze, "Deducing Production Zones from Well Logs," Geothermal Resources Council Transactions, 1, 1977, pp. 279-280.

50. S. K. Sanyal et al. Classification of Geothermal Reservoirs from the Viewpoint of Log Analysis, Twentieth Annual Logging Symposium of the Society of Professional Well Log Analysts, June 1979.

51. R. Aquilera, Naturally Fractured Reservoirs, Tulsa, Oklahoma: Petroleum Publishing Co., 1980.

52. D. R. Ralston, Analysis of Pump Test Results from Tests Conducted in the Raft River Basin, Idaho Bureau of Mines \& Geology, February 1975.

53. A. G. Morilla and D. R. Ralston, "Preliminary Assessment of the Feasibility of Using a Shallow Ground Water System for the Cooling Cycle of a Geothermal Power Plant,"' University of Idaho, 1976, p. 127. 
54. P. A. Witherspoon, T. N. Narasimhan, D. G. McEdwards, "Results of Interference Tests from Two Geothermal Reservoirs," presented at the Fifty-First Annual Fall Meeting of the Society of Petroleum Engineers of the American Institute of Mechanical Engineers, New Orleans, 1976.

55. C. F. Tsang et al., "Variable Flow Well Test Analysis by Computer-Assisted Matching Procedure," Society of Petroleum Engineers of the American Institute of Mechanical Engineers Annual Meeting, Bakersfield, California, April 13-15, 1977.

56. D. Goldman, D. W. Allman, L. L. Mink, "Data Collection and Evaluation of Combined Fractured and Porous Media Flow in a Fluid-Dominated Geothermal System," National Water Well Association Conference, Oklahoma City, Oklahoma, October 1979.

57. D. F. Kunze, R. C. Stoker, D. Goldman, "Heat Transfer in Formation as a Geothermal Reservoir Engineering Tool." National Heat Transfer Conference, Salt Lake City, Utah, August 14-17, 1977.

58. D. H. Tsang et al., "Behavior of the Temperature and Concentration of the Shallow Ground Water in the Raft River Geothermal Area," Modeling, Policy, and Decision in Energy Systems Conference, Montreal, Canada, 1980.

59. S. G. Spencer and D. Goldman, "Numerical Simulation of the Impact of Fluid Injection in the Raft River Geothermal Area," Transactions of the Geothermal Resources Council, 4, 1980.

60. S. M. Prestwich, Drilling \& Completion Report: Raft River Geothermal Injection No. 4 (RRGI-4), ID0-10080, DOE-70, August 1977.

61. L. G. Miller and S. M. Prestwich, Completion Report: Raft River Geothermal Production Well 5 (RRGP-5), ID0-10082, DOE-70, February 1979a.

62. L. G. Miller and S. M. Prestwich, Completion Report: Raft River Geothermal Injection Well 7 (RRGI-7), ID0-10084, DOE-70, February 1979c.

63. R.W. Parsons, "Permeability of Idealized Fractured Rock, Society of Petroleum Engineers Journal, 6, 1966, pp. 126-136.

64. A. C. Gringarten and P. A. Witherspoon, "Method of Analyzing Pump Test Data From Fractured Aquifers," Proceedings of the Symposium on Percolation Through Fissured Rock, Stutgart, Germany, September 18-19, 1972, pp. T3-B1-9.

65. T. N. Narasimhan and P. A. Witherspoon, Reservoir Evaluation Test on RRGE-1 and RRGE-2, Raft River Geothermal Project, Idaho, LBL-5958, May 1977.

66. R. R. Ihrig (ed.), Semiannual Progress Report for the Idaho Geothermal Program, April 1 to September 30, 1979, EGG-2010, March 1980.

67. C. W. Morris, "Raft River Stimulation Treatment Results," Proceedings of the Geothermal Reservoir Well Stimulation Symposium, February 1980.

68. R. R. Ihrig (ed.), Semiannual Progress Report for the Idaho Geothermal Program, October 1, 1979 to March 31, 1980, EGG-2034, July 1980.

69. S. N. Davis and R. J. M. DeWiest, Hydrogeology, New York: John Wiley Inc., 1960.

70. S. G. Spencer and D. M. Callan, An Analysis of the Response of the Raft River Monitor Wells to the 1979 Injection Tests, EGG-2057, 1980. 
71. W. D. Nichols, Simulation Analysis of the Unconfined Aquifer, Raft River Geothermal Area, IdahoUtah, United States Geological Survey Water-Supply Paper No. 2060, 1979.

72. E. H. Walker et al., "The Raft River Basin, Idaho-Utah, as of 1966: A Reappraisal of the Water Resources and Effects of Ground-Water Development", Bulletin of the Idaho Department of Water Administration, 1970, p. 95.

73. R. O. Fournier, "Chemical Geothermometers and Mixing Models for Geothermal Systems," Geothermics, 5, 1977, pp. 41-50.

74. A. J. Ellis and W. A. J. Mahon, Chemistry and Geothermal Systems, New York: Academic Press, 1977.

75. Y. K. Kharaka and I. Barnes, SOLMNEQ: Solution-Mineral Equilibrium Computations, United States Geological Survey Open-File Report 73-002, 1973.

76. C. A. Allen et al., "Geochemical Modeling at Raft River," Geothermal Resources Council Transactions, 3, 1979, pp. 1-4.

77. J. D. Hem, Study and Interpretation of the Chemical Characteristics of Natural Water, United States Geological Survey Water-Supply Paper 1473, 1970. 


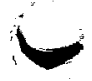

$\bullet$ i 